\title{
From Sinners to Saints: Emerging Agency in American Women's Novels before the Civil War
}

Amy Howard Green

West Virginia University

Follow this and additional works at: https://researchrepository.wvu.edu/etd

\section{Recommended Citation}

Green, Amy Howard, "From Sinners to Saints: Emerging Agency in American Women's Novels before the Civil War" (2013). Graduate Theses, Dissertations, and Problem Reports. 4969.

https://researchrepository.wvu.edu/etd/4969

This Dissertation is protected by copyright and/or related rights. It has been brought to you by the The Research Repository @ WVU with permission from the rights-holder(s). You are free to use this Dissertation in any way that is permitted by the copyright and related rights legislation that applies to your use. For other uses you must obtain permission from the rights-holder(s) directly, unless additional rights are indicated by a Creative Commons license in the record and/ or on the work itself. This Dissertation has been accepted for inclusion in WVU Graduate Theses, Dissertations, and Problem Reports collection by an authorized administrator of The Research Repository @ WVU.

For more information, please contact researchrepository@mail.wvu.edu. 


\title{
From Sinners to Saints: \\ Emerging Agency in American Women's Novels before the Civil War
}

\author{
Amy Howard Green \\ Dissertation submitted to \\ The Eberly College of Arts and Sciences \\ at West Virginia University \\ in partial fulfillment of the requirements \\ for the degree of \\ Doctor of Philosophy \\ in \\ English
Timothy Sweet, Ph.D., Chair
Cari Carpenter, Ph.D.
Michael Germana, Ph.D.
John Ernest, Ph.D.
Janie Hinds, Ph.D.
Department of English

Morgantown, West Virginia

2013

Keywords: American Literature; Seduction Novel; Eighteenth Century; Nineteenth Century; Bildungsroman; Religion; Agency; Women; Reader Response

Copyright 2013 Amy Howard Green 


\begin{abstract}
From Sinners to Saints:

Emerging Agency in American Women's Novels before the Civil War
\end{abstract}

Amy Howard Green

This study investigates the ways in which the narrative of salvation contributed to the development of female selfhood in American women's novels before the Civil War. Over time, protagonists of some of the most popular of these novels were transformed from victims of seduction (as in Charlotte Temple or The Coquette) into self-reliant agents of virtue (as in The Wide, Wide World or The Lamplighter). Such a depiction suggests that a similar shift in readers' imaginations of their own selfhood was also taking place, and it paralleled changes in the genre conventions of novels that have been traditionally identified as "woman's fiction." The examination of how selfhood functions in this fiction employs a concept of agency that is grounded in Michel Foucault's notion of "moral action." Because novels such as these generally sought to promote action that was deemed "moral" by the cultural environments in which they were written, the self that existed in those texts did so in relation to the social order of that time. The novel, as a genre, is especially useful in depicting an imaginary representation of those particular models in and against which a relationship with the self develops; through novel reading, one may imagine differing plot lines or disparate realms which function to reinforce or challenge accepted social norms for behavior. This study contends that the foundation for developing agency in these novels was based primarily on the concurrently fluctuating conception of the self in eighteenth- and nineteenth-century religious discourse as it moved from promoting a Calvinist world view to championing individual free will. As the restrictive Calvinist notion of election declined in popular theology, Americans began to embrace the doctrine of universal salvation that foregrounded the importance of the sinner's ability to choose to accept God's saving grace. 


\section{Acknowledgements}

A simple "thank you" is not sufficient to express my gratitude to my committee chair, Timothy Sweet, for his countless hours of work in helping me to conceptualize, draft, and revise this dissertation. He is a gifted editor with an exceptional talent for helping others to realize their own potential. Without his patience, care, time, and devotion this project would not have been completed.

I would also like to thank the other members of my committee, Cari Carpenter, Michael Germana, John Ernest, and Janie Hinds. Each of them went beyond the call of duty in offering suggestions and support. In particular, I am grateful to John Ernest for reading and responding to more than one draft of each chapter and to Janie Hinds for her encouraging words and ready smile at times when they were most needed.

Finally, I would like to acknowledge my family, without whom I could not have taken this journey. My parents, Andy and Judy Howard, supported me throughout my undergraduate education and cheered me on at every step in this process; their belief in my abilities has been a constant source of inspiration in my life. My sister, Jennifer Albrecht, reassured me and bolstered my confidence on a weekly basis; her love and advice often gave me the fortitude to persevere. My brother, Scott Howard, made me laugh and showed boundless delight for my work. My children, John, Megan, and Rachel, provided the motivation for finishing this project and taught me how to find joy in simple moments: John's smile gave me hope, Megan's admiration gave me confidence, and Rachel's enthusiasm gave me strength. Most of all, though, my husband, John, has supported me in every aspect of my life and work for as long as I have known him. Without his endless and unwavering encouragement, I never could have achieved this lifelong goal. 


\section{Table of Contents}

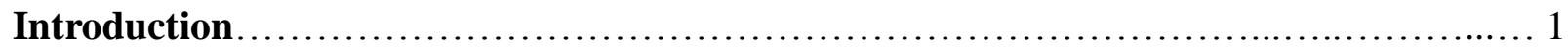

Chapter One: Disparities of Voice and Choice in Charlotte Temple..................... 16

Chapter Two: In Her Own Words: Speaking Selfhood in The Coquette..................... 52

Chapter Three: Kelroy's Problems with Republican Motherhood....................... 92

Chapter Four: Universal Salvation and Emerging Agency in A New-England Tale......... 145

Chapter Five: Female Selfhood as Constituted in Popular Women's Novels of the 1850s:

The Wide, Wide World; The Lamplighter; and Ruth Hall.................... 195

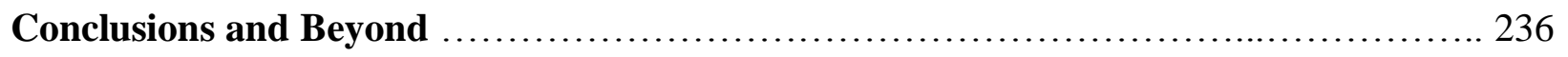

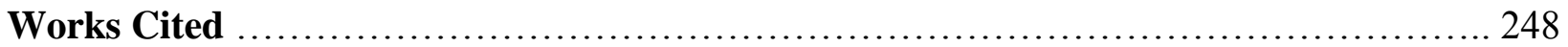




\section{Introduction}

Novels written by women in America in the years following the Revolution are generally categorized as seduction narratives; likewise, most of the novels written by women in the decades prior to the Civil War are referred to as tales of domesticity. The last decades of the twentieth century and the start of the twenty-first have witnessed many exemplary critics reclaiming these previously oft-forgotten works as important literary and cultural artifacts in ways that have helped to explicate more fully our nation's history and culture during that critical era between those two wars. Nevertheless, it is curious that those examinations have offered little thus far in the way of explanation for how the protagonists of some of the most popular writing in America were transformed from victims of seduction in early works like Charlotte Temple or The Coquette into self-reliant agents of virtue in 1850 s novels like The Wide, Wide World or The Lamplighter. In scrutinizing some of these archetypal works of novelistic discourse from the texts published between 1790 and the 1850s in America, I will examine what I take to be the central means by which such a shift was made possible-namely, the depiction of the female protagonists as selves with whom their readers could safely identify. Such a depiction suggests that a similar shift in actual readers' imaginations of their own selfhood was also taking place. The key aspect of selfhood as far as I am concerned is agency, and my study focuses on a conceptualization of selfhood in terms of agency. The developments I posit in the conventions of the self parallel changes in the genre conventions of novelistic discourse in texts that have been traditionally identified as “woman's fiction."

In examining how selfhood functions in this "woman's fiction," I employ a concept of agency that is grounded in Michel Foucault's notion of "moral action." Foucault posits that all such action "involves a relationship with the reality in which it is carried out, and a relationship 
with the self' (28). Because novels such as the ones I am studying generally seek to promote action that has been deemed "moral" by the cultural environments in which they were produced, the self that exists in these texts does so in relation to the social order of that time. As the self develops, it responds to the various possibilities and restrictions inherent in the social roles available to it at that time and in that place. This conceptualization of agency reflects Foucault's contention that "a history of the way in which individuals are urged to constitute themselves as subjects of moral conduct would be concerned with the models proposed for setting up and developing relationships with the self" (29).

The novel, as a genre, is especially useful in depicting an imaginary representation of those particular models in and against which a relationship with the self develops; through novel reading, one may imagine differing plot lines or disparate realms which function to reinforce or to challenge accepted social norms for behavior. As Cathy N. Davidson notes, "novels struggle with the regulation of private behavior in the face of public morality" (Revolution and the Word 19). Ironically, the private regulation encouraged by such novels often occurred "in the face of [a] public morality" that depicted novel reading as immoral. ${ }^{1}$ The public censure of the private and increasingly popular act of novel reading spoke directly to that genre's capacity for challenging social norms; as Davidson argues, "Had the novel not been seen as a covert or even overt critique of the existing social order, there would have been no need to defend so rigorously what had not been called into question or to strive to persuade potential novel readers of the harm that they would do themselves should they foolishly indulge their appetite for fiction"

\footnotetext{
${ }^{1}$ As Davidson observes, "Yet the censure of the form, emanating from the pulpit and the press, remained potent enough... until well into the nineteenth century [that] virtually every American novel somewhere in its preface or its plot defended itself against the charge that it was [emphasis Davidson's] a novel, either by defining itself differently ("Founded In Truth") or by redefining the genre tautologically as all those things it was presumed not to be - moral, truthful, educational, and so forth" (Revolution and the Word 103).
} 
(Revolution and the Word 103-4). Readers of novels were well positioned, then, to experience the plurality of possibilities inherent in the representations of the social order offered by such works. Novels afforded readers the ability to imagine a variety of potential outcomes to which non-readers were not privy; in particular, marginalized members of that society would have been especially likely to develop a sense of how to act morally within and outside of those parameters. Women who read novels were thus better positioned to cultivate a relationship with the self that could foster moral action than non-readers would have been.

The agency posited in these novels always exists, then, in relation to specific cultural contexts. The key context I examine is the shift religious discourse underwent in early America from promoting a Calvinist world view to championing individual free will. I argue that the foundation for developing agency in these novels was based primarily on the concurrently fluctuating conception of the self in eighteenth- and nineteenth-century religious discourse; as popular theology began to embrace universal salvation rather than the restrictive Calvinist notion of election, it foregrounded the importance of the sinner's ability to choose to accept God's saving grace. Free will, independence, and choice were obviously concepts that were bound up in the political ideologies of the new republic as well. However, whereas recently several notable scholars have examined the connections between some of those early novels and the ways in which they reflected developing models of nationhood, and while many historians have also observed associations between political and religious ideologies of that era, only a few have commented on the ways in which novelistic discourse echoed and complicated certain theological doctrines in terms of the development of selfhood and agency for female protagonists and their primarily female readership. 
Scholarly investigations of these novels have often theorized about the extent to which their female protagonists may be read as exerting agency within the bounds of the hegemonic, patriarchal culture in which they were produced and consumed. Nina Baym was one of the first to take up these questions in her seminal work, Woman's Fiction: A Guide to Novels by and about Women in America 1820-1870. In her new Introduction to her second edition of that study, she contends that "The protagonist — and her readers vicariously_learn that women must become people to survive in a difficult world; they also learn that women can [emphasis Baym's] become people, because persons, selves is what they all potentially are" (ix). Baym postulates that one function of this literature, then, was to educate readers on their own potential selfhood. As she discusses the concept of selfhood put forth in woman's fiction, she defines it as an expansion of the interior lives of those individuals to the point where the self becomes a domestic site. This self consciousness is developed in a private space in order to do the public work necessary to support a middle-class ideology: "Thus, while these teaching books participate in a middle-class program to develop 'individuals,' or at least a belief in them, the ideology has public as well as private intentions - it aims to stabilize the middle class. A self is never merely itself but is always an aspect or expression of larger social formations or existences" (xxii). Baym's study begins in 1820; in my view, that process of education had already been going on for quite some time in America by then. Thus, I believe that the female protagonists of these works modeled for their readers options for enacting that selfhood that went beyond the mere recognition or expression of it, so, in addition to the process of education described by Baym, I see them as having modeled modes of potential agency for their readers to experience vicariously and thereby consider enacting in their own lives. 
Cathy N. Davidson has also reflected on some aspects of these same issues in her work. Davidson considers agency primarily in terms of the subversive potential of fiction as a literary form in her ground-breaking study, Revolution and the Word: The Rise of the Novel in America. Whereas her original analysis had been weighted with a binary model of power structures that employed fixed categories like “the novel versus the Founding Fathers" (24), Davidson's recently expanded (2004) edition takes a more nuanced approach to the cultural function of texts she had previously viewed as subversive by "present[ing] a less didactic model for the impact and responsibility of writers on the process of social change" (26). She does, however, still read the novel as a significant expression of the cultural disparities produced by the Revolution between the sanctioned, public image of "America" and the experience of actual independence for its populace. She examines the "glaring gap" in these novels "between the public morality officially espoused and the private behavior of the characters who voice or supposedly validate that morality," and she considers the female reader of those works as one who may hold "private reservations about her own limited legal and social standing as opposed to her public acceptance of ostensibly unquestioned social values and established good order" (215). Davidson locates the potential agency of these works, then, more in terms of the discrepancies between public and private discourses as they often raised issues that the dominant ideology would have preferred to have kept repressed. My own readings of these novels certainly makes use of many of Davidson's theories about readers and authors, the political and social contexts in which they existed, and the multiple potential configurations of power suggested by them. I focus my approach more narrowly, though, on the specific function of evolving theologies in advancing the potential for agency in female protagonists and their readers during that time. 
So, whereas Davidson explores shifting attitudes towards the social authority of the public church in Americans' private lives and locates the novel as an expression of or challenge to certain aspects of religious authority as they play out in society and in the home, I look instead to specific changes in the narrative of salvation in theological discourses as assisting in bringing about a concurrent revision of the way the self enacts agency in these works. Other critics have probed the connections between agency and religion in their works as well. Notably, Jane Tompkins, in Sensational Designs: The Cultural Work of American Fiction 1790-1860, contends that the agency accessible to women in antebellum America was based on a typological view of the world in which total obedience (to God and His representatives here on earth, men) and selfabnegation were necessary for the meek (women) to inherit the earth. As Christ was obedient to God even unto death, so too should women be, in this typological reading, because only as Christ's representatives here on earth could they have access to power. Tompkins characterizes this type of submission as, "a self-willed act of conquest of one's own passions"; accordingly, she argues, it is "not capitulation to an external authority, but the mastery of herself, and therefore, paradoxically, an assertion of autonomy" (162). She proposes that "the popular domestic novel of the nineteenth century represents a monumental effort to reorganize culture from the woman's point of view" (124). What these novels portray, she argues, is that women occupied the central position of power and authority in that culture. While her theories offer a productive reconfiguration of the power structures in that time that certainly inform my work, I argue that the selfhood depicted in these novels had evolved by the 1850s to the point where actual agency was being modeled by these heroines as they ventured out into the world and beyond the realm of the domestic. While the domestic sphere and a religious validation of their 
own purpose in the world may have sparked the development of agency for these protagonists, I trace the increasing secularization of that agency in later works as well.

Tompkins' foundational work in explicating the connection between theology and agency has been built upon by other critics in more recent years. One who has looked specifically at the genre shift from seduction narratives to domestic ones is Elizabeth Barnes; in States of Sympathy: Seduction and Democracy in the American Novel, she explains this transition by considering it to be a shift in the location of virtue from material—in the virginal body of the protagonist in seduction tales — to spiritual — in the regenerated heart of that woman in domestic novels. Rather than viewing the move as progressive, though, Barnes claims that domestic fiction aims to perfect the same sentimental strategies of affective representation as were previously seen in seduction tales by successfully converting the material body into the immaterial soul. Sentimental literature as a whole, therefore, should not be read as a separate "woman's" fiction but rather must be seen as essential to the construction of a patriarchal state, according to Barnes. While her theories are fascinating and useful in reconceptualizing the function of sentimental literature, I argue that this transition is in fact progressive and that it represents the ever-increasing agency of the protagonists of these novels and, potentially, their readers just as the concurrent progress in developing theologies concerning the narrative of salvation did.

One critic who has considered salvation in terms of a protagonist's potential for modeling agency is Marion Rust in her work, Prodigal Daughters: Susanna Rowson's Early American Women. She claims that Charlotte Temple was the chief example of a female prodigal figure who chooses to return to her father's loving arms, thereby allowing her to embody (in a woman's body) the early national, Lockean ideals that emphasized "man's individual, as well as political, 
capacity for self-determination" in a "culture once schooled in Calvinist doctrines of original sin, sanctification, and justification" (51). Rust re-imagines the story of the prodigal son in terms of the political climate in post-Revolutionary America by asserting that it privileged "a son [(America)] who disappears and then returns to law-abiding society" as one who "possess[es] new, special understanding unavailable to one who has never left" when she argues for "an emphasis on the self that in some sense chooses to return, rather than [emphasizing] the God that allows the fall" (51). Rust's work productively delineates the intersection of patriarchal norms, politics, and religion in the early national period and explores their effects on female protagonists and their readers. Her reading of Charlotte Temple also claims that the narrative of the prodigal son offered potential sinners-like Charlotte who chooses to return to the loving embrace of her father (both worldly and heavenly) and thereby assure her own salvation in the brief moments before her death — a type of agency that she terms "moral agency" (Rust 69). I employ this concept of moral agency in my own readings of Charlotte Temple and later novels, but I believe that it may be productively applied to narratives of salvation that are not limited to the gendered positioning of the self that the prodigal son story necessitates.

Like Rust's work, then, much of the recent criticism of these novels has centered not on the previously-necessary process of recovery initially undertaken by scholars like Baym and Davidson but instead on the critical development of the place of these works within the canon of American literature and culture. In Early American Literature in 2013, Karen Weyler observes that new scholarly editions of works like Charlotte Temple, published in 2011 in a Norton Critical Edition, and The Coquette, re-released in 2011 by Broadview in a critical edition, afford these works the type of "scholarly treatment once reserved for the works of canonical male authors such as Nathaniel Hawthorne and Herman Melville" (232). Contemporary criticism of 
these works and their popular nineteenth-century counterparts has kept pace with other trends in current criticism, like, for example, the move towards transatlantic interconnectivity, which suggests Weyler's comments are on point. ${ }^{2}$ Not every popular critical trend need be applied equally to these works in order to fortify their place in the canon, however; indeed Weyler laments the slowdown in the process of recovering other lesser-known women's novels as more is done to solidify the significance of the few texts already in readily-available editions. Because my own work explores the implications of the narrative of salvation that pervaded eighteenthand nineteenth-century novelistic discourse, it can be productively applied to those iconic texts as well as to lesser-known works that may yet be recovered as worthy of further study and criticism.

I add my voice to this evolving discussion by investigating the ways in which the narrative of salvation contributed to the development of female selfhood in American women's novels before the Civil War and thereby aided in promoting the shift from sinning protagonists to saintly ones. That narrative originated in a Calvinist theology that represented the sinner, male or female, as equally, inherently depraved but also equally likely to be saved—but it afforded him or her no ability to effect that salvation. While the Great Awakening in the 1740s suggested that that salvation could become knowable through an examination of one's heart, it still maintained the notion of selective election that excluded salvation for all but God's chosen people and preserved a belief in the inherent nature of original sin. The popularity of revivals during this time period did, however, mark a change in the everyday experience of religion in many people's lives and assisted in the propagation of rival theologies that afforded sinners more

\footnotetext{
${ }^{2}$ Just one example of the (at times, forced) move to include women's novels now considered canonical in the current trend towards transatlantic criticism can be seen in Jessica DeSpain's article, "Ellen's English Dress: American Religious Practice And The British Reprints Of Susan Warner's The Wide, Wide World," published in Symbiosis: A Journal Of Anglo-American Literary Relations 16.1 (2012): 113-134.
} 
agency in their own salvation by arguing that sin was a personal act rather than a native condition. The acceptance of such free-will doctrines increased following the Revolution as Calvinist theologies declined in popularity after constitutional disestablishment and as competing doctrines began to embrace the concept of universal salvation. Salvation narratives in novelistic discourse underwent a parallel shift as female protagonists began to be depicted not as sinners whose choices demonstrated their innate depravity but as potential saints whose choices could ultimately determine their own salvation. Eventually, by the 1850 s, this free-will narrative of salvation would enter a secularized phase wherein the heroine's choices could bring about a kind of salvation in the secular realm as well as the spiritual one. My study examines exemplary representations of this progression from the early years of nationhood up to the Civil War.

Chapter One, "Disparities of Voice and Choice in Charlotte Temple," investigates the process by which Charlotte Temple was able to begin to encourage readers in that time to develop what Michel Foucault has called a "relationship with the self," ostensibly in order to inspire them to make moral choices in their own lives and thereby start to become what Foucault has termed "ethical subjects." In particular, I examine the external, cultural constraints of religion, virtue, and paternal approbation as they function in this novel to contain the threat female sexuality implied to the dominant, patriarchal ideology of the time. Assisting young, female readers in learning to internalize those external constraints and thereby ensure her own happiness is, according to the narrator, the main goal of Charlotte Temple. However, I contend that the narrative representation of those external controls and the resultant consequences of the protagonist's failure to internalize them also function contrary to their stated aims by allowing female readers to create an imaginary space in which they may fantasize about acting out their own desires. In that case, we can view the ability to imagine female desire as an indication of a 
concurrent development of the feminine capacity for selfhood and agency. Certainly wellknown, similar novels that may have been read by the same audience, like Samuel Richardson's Pamela or Clarissa, could have also encouraged the development of female selfhood, but those narratives feature protagonists whose choice not to give in to their desires affords them a sense of agency. Charlotte Temple, on the other hand, features a protagonist whose choice to act on her desires models for readers the latent agency of such a decision and whose plot comes to fruition in America. That such a choice at such a time must also necessitate her own destruction is mitigated somewhat by her spiritual salvation at the close of the narrative.

In Chapter Two, "In Her Own Words: Speaking Selfhood in The Coquette," the potential agency modeled by a female protagonist who gives in to her desires is directly voiced by that woman as she tells her own tale through her first-person letters. The epistolary form renders the modeling more immediate and potent than Charlotte's, and Eliza Wharton also voices more awareness of her own desires and the consequences of acting on them than Charlotte ever did. In self-consciously seeking "pleasure," as she terms it in the book's opening letter, Eliza ventures down what she perceives to be the one avenue open to her as a means of articulating her self identity in the face of the boundaries delineated by the cultural constraints of proper female behavior. The controls of religion, virtue, and paternal approbation are refigured here in the voices of the other letter writers as they speak to Eliza and each other about Eliza's desperate attempts to cling to her own sense of herself; that Eliza ultimately chooses a path of self destruction rather than abdicating her sense of her self suggests the complicated dangers inherent in any expression of agency for women of this time. Yet, such a choice, like that of Charlotte Temple, also serves to encourage readers to experience vicariously the pleasures of agency while it allows them to avoid the literal consequences of doing so. Because Eliza Wharton's actions 
and choices are governed by a self-conscious exercise of will, I also examine the notion of consent as an act of choice and will in political and theological terms. I suggest that religious discourse emerged as a means of conceiving of women as equal to men because both were considered equal in terms of the salvation of their souls. In some theological discourses of that time, an exercise of the will could have resulted in either the destruction or the salvation of the soul, but only if God chose to offer such salvation. By considering the competing theologies of the eighteenth century and their possible representations in The Coquette, I draw a parallel between the sinner's options and those of Eliza. Eliza's story can be read as one that expresses an increasing awareness of the potential for female agency while simultaneously cautioning readers who hope to retain a modicum of self identity while they seek to negotiate the narrow gap between choice and submission.

Chapter Three, “Kelroy's Problems with Republican Motherhood,” retrospectively positions Kelroy as a transitional novel between seduction tales and domestic narratives. The move from the negative didacticism inherent in novels of seduction (as they ostensibly encourage readers not to model the female protagonist's behavior) into the era of overtly positive didacticism (that presents female protagonists as ideals of feminine virtue as seen in the novels of domesticity so popular in later years) can be seen in this novel. Kelroy exemplifies many of the shifting cultural and religious norms at work during this time; those changes are demonstrated in the reversals of several of the traditional circumstances of the novel of seduction that are set up in the beginning of the story but then are either frustrated, inverted, or altogether absent. Because it seldom conforms to genre expectations, Kelroy is difficult to classify; some have described it as a tragedy whereas others refer to it as a gothic plot. The tensions between these two modes play out throughout this narrative and contribute to the disturbing air of 
uncertainty that pervades it. Whatever literary modes are being accessed in this novel, they all speak to one central, ideological question about what constitutes acceptable female agency in the new republic. Mrs. Hammond, the protagonist's mother, has too much agency, and her daughter Emily, the supposed heroine of the tale, does not have enough. In reversing the expectations for the role of the mother in seduction narratives, Mrs. Hammond personifies for readers the threat of unmitigated female agency in an era which purported, under the ideology of republican motherhood, to value women as the producers and educators of potential citizens for the new nation. In negating the customary moral authority of parents and religion in a young woman's life, Kelroy upends the traditional didacticism of reader identification with its female protagonist and thus leaves the reader without a workable model for selfhood. Accordingly, Emily's senseless death demonstrates the need for a new model to emerge.

Chapter Four, "Universal Salvation and Emerging Agency in A New-England Tale," also focuses on the era of republican motherhood, but, unlike Kelroy, which questioned the workability of those expectations, A New-England Tale suggests that the potential for female agency offered by that ideology may have had its genesis in the religious questions of free will and salvation that were at stake for all people in New England in the first half of the nineteenth century. Catharine Maria Sedgwick takes up notions of passivity and deferral that are characteristic of republican motherhood, but, rather than limiting them to the realm of social, gender, or political roles, she maps them onto her own beliefs about Calvinism versus other increasingly popular denominations that offer sinners some agency in their own salvation. Sedgwick contends that Calvinism is no longer a viable dogma because it requires the utter passivity of its adherents. Whereas Kelroy broke down but never attempted to rebuild many of the stereotypical characteristics of earlier novels of seduction, A New-England Tale reforms 
several of those commonalities into the themes and tropes that would come to dominate novels of domesticity in the decades that followed it. While much of it still reifies patriarchal authority and affectional marriage as the ultimate sources of female happiness, ironically suggesting that only in submitting to such conventions could women find their own true path in life, it nevertheless also offers its readers several examples of positive female behavior, self identity, and agency through which they can begin to imagine themselves making similar choices in their own lives.

In Chapter Five, “Female Selfhood as Constituted in Popular Women's Novels of the 1850s: The Wide, Wide World; The Lamplighter; and Ruth Hall," I trace the trajectory of emerging female selfhood from the earlier novels in my study through to its fruition in the popular novels of the 1850s. Because A New-England Tale offered its female readers a way to imagine agency in terms of their own salvation and thereby afforded them a path to selfexpression bolstered by the normative theological doctrines of that era, it also paved the way for a figurative system to develop in later novels wherein salvation could be conceived of in nontheological terms, particularly by the middle-class Protestant women who were their primary readers. The development of a more worldly female self that has the ability to choose rightly a course of action in order to effect a productive change in her own life and potentially in her society accordingly becomes valorized as a moral act in and of itself as later novels and their heroines come to productive fulfillment. In order to see her own potential to act in the world, the female protagonists in these later novels, and their readers, had to have already conceived of themselves as selves. Their challenge is not to develop such a self, then, but to take full control of that self and use it to effect some beneficial change in their own world, be it familial, communal, social, or political. If we view these novels in a line of development using certain 
exemplary texts beginning with the publication of The Wide, Wide World in 1850, we can see how the assumptions and norms of that novelistic realm progress into those of The Lamplighter in early 1854 and, in turn, of Ruth Hall in late 1854. The role of the mother in the growth of the main character's sense of self, the valuation of spiritual and/or communal ties over familial bonds, and the emerging ability of the female protagonist to interact with a secular world and thereby ensure her own salvation all advance and are challenged along with the genre itself. The rapid progression of agency exemplified by the heroines of these novels becomes the foundation for future modes of female selfhood to flourish in later texts.

The "Conclusion" briefly examines some of those future modes in three exemplary novels, The Hidden Hand, The Morgesons, and The Story of Avis. In order to exert their freewill options, protagonists in domestic novels had had to sacrifice the expression of sexual desire upon which the demise of characters like Charlotte Temple or Eliza Wharton had been predicated. Later figures like Emily Hammond, Jane Elton, and Ellen Montgomery had had to sublimate their bodily desires in exchange for the type of agency offered in choosing spiritual fulfillment. Subsequent novels, like the ones I survey, struggle to envision a world wherein such an exchange is no longer necessary and thereby begin to conceptualize of women as fully actuated selves, no longer simply sinners or saints. 


\section{Chapter One: Disparities of Voice and Choice in Charlotte Temple}

\section{Introduction}

In the time since Jane Tompkins first claimed Susanna Rowson to be the " "father of the American novel"' at a talk given at the MLA Convention in 1985, many critics have similarly sought to re-position Charlotte Temple at the head of our canon of American literature. By 1989, Cathy N. Davidson had begun to examine how a "simple" text like Charlotte Temple could have come to be "viewed as a novel that, more than any other, signaled a new era in the history of the book in America" ("The Life and Times" 158). Indeed, from the time Nina Baym wrote in 1978 that Charlotte's story was “the simple, trusting heroine's seduction, subsequent abandonment and sufferings, and ultimate death from poverty, exhaustion, and fever," feminist critics have sought ways in which to re-envision Charlotte's plight as more than what Baym labeled it: "demoralized literature" that "present[ed] an unqualified picture of woman as man's inevitable dupe and prey" (Woman's Fiction 51). ${ }^{1}$ One of the recent and most productive analyses of Charlotte Temple is Marion Rust's study, in which she looks to reconfigure the entire notion of sentimentality within the narrow gap between autonomy and submission in both the work and the life of Susanna Rowson. ${ }^{2}$ Rust claims that Charlotte was the first instance of a female prodigal figure returning to her father's loving arms, thereby allowing her to embody (in

\footnotetext{
${ }^{1}$ Some critics, like Davidson herself in Revolution and the Word (1986), chose to look at the historical and social contexts in which Charlotte Temple was read and thereby problematize the sentimental assumptions associated with it. Others, like Susan K. Harris in $19^{\text {th }}$-Century American Women's Novels (1990), preferred to empower the reader, or what she termed the "narrator-narratee relationship," as a means of valorizing didactic novels like Charlotte Temple. More recently, critics like Julia A. Stern in The Plight of Feeling (1997) and Elizabeth Barnes in States of Sympathy (1997) have sought to read Charlotte's story as a feminized counter-narrative written in contrast to male versions of the political struggle of founding a new, democratic nation.

${ }^{2}$ Rust argues that Charlotte Temple's effect on its young, female reader was to, "awaken... her to her own dissatisfaction with the limited arena in which her powers of choice and selection were seen to operate" (51). In so doing, she convincingly argues that "Rowson taught her primarily Anglo-American female readership both the cruel irony of their situation, as emblems for an individuality to which they were not in fact party, and how to develop workable selves and workable lives nonetheless" (Rust 56-7).
} 
a woman's body) the early national, Lockean ideals that emphasized "man's individual, as well as political, capacity for self-determination" in a "culture once schooled in Calvinist doctrines of original sin, sanctification, and justification" (51). Rust re-imagines the story of the prodigal son in terms of the political climate in post-Revolutionary America by asserting that it privileged "a son who disappears and then returns to law-abiding society" as one who "possess[ed] new, special understanding unavailable to one who has never left" when she argues for "an emphasis on the self that in some sense chooses to return, rather than [emphasizing] the God that allows the fall" $(51) .^{3}$

While Rust's compelling work nicely delineates the intersection of patriarchal norms, politics, religion, and female sexuality in the early national period, its conclusions nevertheless perpetuate the contextualization of Charlotte's tale within a normative, Christian, and patriarchal one: the story of the prodigal son. However, Rust rightly notes that at that time the "powers of choice and selection" available to women were severely limited and usually functioned only so long as a woman had a commodity, her sexuality, to offer in the marketplace; so, Rust seeks instead to show that Charlotte Temple could have offered women another position from which to seize the power of choice - that of a prodigal, like Charlotte, who chooses to return to the loving embrace of her father (both worldly and heavenly) and thereby assures her own salvation in the brief moments before her death. She terms this power "moral agency" (Rust 69). Rust reads into this position the metaphoric salvation of the new nation as it encouraged narratives that legitimized self-determination while still calling for a national one that necessarily subsumed that same individuality in order to survive as a political whole; in other words, in leaving the

\footnotetext{
${ }^{3}$ She supports her contentions by using Jay Fliegelman's line of reasoning from Prodigals and Pilgrims: The American Revolution Against Patriarchal Authority, 1750-1800: “As Fliegelman has argued, Franklin's Autobiography gives voice to the early national belief that a prodigal son who has corrected himself is more valuable as a testament to self-improvement than would be one who had never failed" (Rust 51-2).
} 
protection of the British Empire, America gained what Rust terms a "special understanding" that it would not otherwise have had, but it had to return to a form of organized (patriarchal) government in order to continue its ultimate path to salvation. So, for Rust, Charlotte's story is not a narrative of either submission or rebellion so much as it is a reinscribing of patriarchal, early-national values from a woman's point of view, aimed at female members of that new republic. Rust contends that Charlotte moves from a position in which she is "unable to act on any predilection, including that of a barely registered sexual yearning, to determining her daughter's guardian in the last moments of her life"; this move, she asserts, "suggests that the desire... [Charlotte] once neither heeded nor subjugated has undergone some form of transmutation in order to serve as the basis for a sophisticated moral agency" (69).

Still, Rust's definition of "moral agency" necessitates the positioning of Charlotte in much the same way as Baym did; according to Rust, Charlotte had to go through the entire experience of the novel as a hapless victim of her own and others' uncontrolled and uncontrollable desires, "unable to act on any predilection," in order to learn the lessons she needed to learn and thus be capable of making the choice and of asserting her newfound "moral agency" to return to her father (both earthly and heavenly) and to choose him as the guardian for her daughter (a baby, free from all desires, who stands as the symbol of unspoiled feminine purity on which the future of the Temple family, and symbolically the new nation, may be built). In other words, Rust does not see Charlotte as being capable of that choice, of "moral agency," until the final pages of the story when she chooses to return to her father's loving embrace. Furthermore, Rust argues that "there is a tension in the novel, then, between understanding desire as an impediment to autonomy (such that the seduction novel must warn against it in a fledgling republic) and seeing the former as in some sense primary to the latter (as I am suggesting 
Charlotte's final gesture should be read)" (69). For Rust, then, desire must be read as the first step in the necessary progression to the development of agency in a "fledgling republic" such as America in the late eighteenth century; the only other viable option she explores is the patriarchal view of female desire as an "impediment to autonomy."

What if, though, we were to view desire not as a forerunner to a woman's ability to develop “moral agency," or as a hindrance to a nation's ability to self govern, but instead as evidence of the possibility of agency? What if the development of female desire actually indicates a concurrent development of the feminine capacity for selfhood, choice, and agency? What if novels of seduction could be read not as (n)either narratives of submission ( $n$ )or those of rebellion, but rather as the moment where both possibilities intersect, as they do in the acts of agency now imaginable for their female protagonists, and, ultimately, for what Davidson refers to as their "new kind" of female readership? In that case, Charlotte Temple's popularity in America could be linked to the exceedingly American belief in an individual's right to choose. In juxtaposing the boundaries of acceptable, moral behavior against the vicarious pleasures of imagining acting on one's desires, Charlotte Temple is able to model for its readers a female protagonist who, in experiencing the thrills of her new-found adolescent yearnings, finds herself developing a concurrent capacity for performing acts of agency (albeit initially passive ones) and consequently is able to begin to cultivate her own self identity. The normative Protestant codes ostensibly employed to delineate the acceptable margins of Charlotte Temple's behavior therefore function paradoxically in that they actually serve to open an imaginary space wherein readers can begin to envision the possibility of acting on their own desires. A model of selfhood thus develops as a result of the external pressures of what Charlotte's narrator identifies as "religion," "virtue," and "paternal approbation" (Rowson 26). 


\section{II. "Religion," "virtue," and "paternal approbation": What's a girl to do?}

While so many of the recent critical recoveries of Charlotte Temple captivatingly position the novel in terms of its relationship to (or function as a product of) American literary nationalism, Charlotte's narrator points out that the more immediate contemporary concerns for both Charlotte herself and for her presumptively female readers are ones involving the societal boundaries of "religion," "virtue," and "paternal approbation" (Rowson 26) which traditionally would have mandated, controlled, and mediated the ways in which those female readers would have experienced both their own desires and their place in the new nation. Indeed, as Rust notes, “This early national emphasis on man's individual, as well as political, capacity for selfdetermination cannot be overestimated for its impact on a culture once schooled in Calvinist doctrines of original sin, sanctification, and justification" (51). Her comment speaks to the ways in which Rowson's narrative might have functioned as a type of patriarchal propaganda in the new republic by modeling the national ideal of self determination while still reinscribing it safely within the familiar, Christian story of the prodigal son in order to contain it for the sake of national unity. In this sense, Charlotte's demise at the end of the novel can be read as helping to reign in the developing threat of a potential female capacity for self determination while still relying on those same Calvinist values to further the notion that the new republic would only offer actual equality, and selfhood, for its white, male members (or, as Rust puts it, "an individuality to which [women] were not in fact party" (57)). Despite that reality, I contend that the very existence and subsequent popularity of a figure like Charlotte points to the possibility of a concurrently developing female capacity for agency and self determination in the new nation. So, I maintain that the societal boundaries of "religion," "virtue," and "paternal approbation" that are set in place to contain such a development often belie their overt function by becoming the 
very means by which female readers can learn to erect imaginary spaces in which they may envision acting according to their own desires as well.

By imagining the pleasures of giving in to their desires and acting as Charlotte did, I argue that female readers of Charlotte Temple are able to start to form what Michel Foucault calls "a relationship with the self" in order thereby to begin to develop a sense of agency and a capacity for self determination in their own lives and realities. ${ }^{4}$ How the beginnings of such a development matured in the nineteenth century is a topic I will address in later chapters of this study. Foucault poses the question: "How did sexual behavior...come to be conceived as a domain of moral experience?" (24). He starts to answer this question by first defining what he means by "morality": "a set of values and rules of action that are recommended to individuals through the intermediary of various prescriptive agencies such as the family,... educational institutions, churches, and so forth." But, he argues, morality goes beyond the setting forth of rules and must also refer to "the real behavior of individuals in relation to the rules and values that are recommended to them" (Foucault 25). In exploring such moral behavior or action, then, Foucault theorizes that

...all moral action involves a relationship with the reality in which it is carried out, and a relationship with the self. The latter is not simply "self-awareness" but self-formation as an "ethical subject," a process in which the individual delimits that part of himself that will form the object of his moral practice, defines his position relative to the precept he will follow, and decides on a certain mode of

\footnotetext{
${ }^{4}$ Certainly, Charlotte Temple was not the only novel by which female readers in America could have had this vicarious experience. Samuel Richardson's Pamela and Clarissa were popular examples, and, as epistolaries, their mimetic potential could be viewed as more immediate for readers. However, those tales predicate the development of agency on the heroine resisting giving in to desire, whereas I suggest that Charlotte's developing agency came about in conjunction with her sexual maturation, and, in some sense, may have proceeded from her capitulation to it. I will explore the potential of the epistolary form in my next chapter on The Coquette.
} 
being that will serve as his moral goal. And this requires him to act upon himself, to monitor, test, improve, and transform himself. There is no specific moral action that does not refer to a unified moral conduct; no moral conduct that does not call for the forming of oneself as an ethical subject... Moral action is indissociable from these forms of self-activity. (28)

In imagining giving in to desire, as readers of Charlotte Temple must have done, those readers begin the process of establishing "a relationship with the reality" in which such a choice can be made and in which "a relationship with the self" can be formed. It is that very act of vicariously imaging desire, then, that affords them the ability to begin to imagine their own potential agency by starting to develop "ethical subjects" that can choose to act morally or not. In exploring the ways in which the formation of desire itself can be read as an act of (moral) agency for female members of the new republic, I argue that the juncture of those societal forces generally thought to act as fields of containment for such a development - specifically what Charlotte's narrator names as "religion," "virtue," and "paternal approbation" — can actually be seen as serving to highlight the potential spaces in which such an act can occur.

How could a seemingly patriarchal, and often hegemonic, force such as "religion," one that on its face appears to function as a means to contain, limit, and control female desire, agency, and autonomy, actually serve to open a space in which those very notions could find their genesis? Ann Braude notes that

Since the eighteenth century, American Protestantism has been dominated by an evangelical religious style, which encouraged Christians to focus on individual religious experience rather than on the ceremonies of the church. Evangelicals, like the Puritans before them, believed that each person who was saved by God 
would have a compelling internal conversion experience. But whereas the Puritans believed that only the few elect would experience conversion, by the nineteenth century the new revivalist denominations (like the Methodists) believed that everyone could experience God's grace. (28-9)

Beginning with the Great Awakening in America in the 1740s, revivalism encouraged all individuals (even women, the poor and disenfranchised, and slaves), rather than select groups of God's elect, to seek a direct experience of God's grace. Popular preachers like Jonathan Edwards and George Whitefield called on sinners to seek a true conversion, or "change of heart," at huge meetings attended by hundreds or even thousands of followers. Some of those revivals abandoned traditional Calvinist notions of selective election and instead allowed for the prospect of universal election, thus making Christ's grace possible for all people. Edwards invited individuals to choose to accept salvation in his famous sermon, "Sinners in the Hands of an Angry God," given in 1741: "And now you have an extraordinary opportunity, a day wherein Christ has thrown the door of mercy wide open, and stands in calling and crying with a loud voice to poor sinners; a day wherein many are flocking to $\mathrm{Him}$, and pressing into the kingdom of God" (435). Salvation, for Edwards, may have been invited by Christ, but it had to be sought by the sinner; for Edwards and his followers, it took an act of choice to enter the kingdom of God by choosing to accept Christ's mercy and grace. The idea of this ability of an individual to choose to act morally and to choose to act to receive the salvation offered by Christ rather than waiting for election by God seeped into popular culture in eighteenth-century America.

The significant rise in popular revivals in pre-Revolutionary America has long been touted by historians as a key factor in the development of ideals that led to the Revolution. Jon Butler names Carl Bridenbaugh and Alan Heimert as the "seminal" influences in this line of 
scholarship in the 1960s; he further notes that more recent historians, like Gary Nash, Rhys Isaac, Harry S. Stout, and Patricia Bonomi, "have stressed the importance of evangelical 'style' in shaping the Revolution. In these accounts, evangelicalism underwrote economic discontent, fostered new modes of public address, and provoked confrontations with the standing order that eroded public confidence in the established government and played a substantial role in turning protest into rebellion" (Butler 196). Despite this weight of scholarship, however, Butler argues that the historical and critical emphases on revivalism as the major cultural source of "revolutionary antiauthoritarian" sentiment overlooks important subtleties and crucial realities in eighteenth-century American religious development: "For better or worse, the state church tradition [i.e. Anglican and Congregational], rather than Dissenting evangelicalism or voluntaryism, gave Christianity its primary shape in eighteenth-century colonial American society" (165). Furthermore, Butler claims, "At its heart, the Revolution was a profoundly secular event" that "placed religious concerns more at its margins than at its center" (195). However, without the preponderance of diverse Christian experiences and religious heterogeneity, Butler asserts, Christianity in America would have remained narrowly English and perhaps less primed for the Revolution: "Before 1740 not a single New England town, parish, or provincial leader called for abolishing the state church system, despite New England's increasing religious and social complexity" (170); yet, in the decade following the Revolution, establishment religion was only sustained in Connecticut and Massachusetts. Butler claims that this shift did not indicate an antiauthoritarian sentiment in popular pre-Revolutionary American culture but instead actually reflected a popular desire to give over more authority to individual denominations rather than a state-endorsed establishment. He calls this "shift of religious authority away from the state and toward the "voluntary' institutional bodies" "the single most 
important institutional development of postrevolutionary Christianity," and says that "Out of [it]...came an extraordinary expansion of denominational institutions, new means to reach great numbers of individuals and groups, and a new confidence to shape society and its values" (Butler 268). Nonetheless, Butler contends, "Such events triggered their own distinctive tensions. The emphasis on denominational authority clashed with the egalitarian values of the American Revolution" (268).

This tension between "denominational authority" and "egalitarian values" is, I contend, at the heart of Charlotte Temple's portrayal of religion in only the most general and vague terms while the novel as a whole still strives to maintain religious ideals as the apparent basis for safely circumscribing female desire within the bounds of "religion," "virtue," and "paternal approbation." Charlotte's ability to choose whether or not to act on her desire becomes, then, the pivot point between emphasizing the "egalitarian values" of the American Revolution and still maintaining the patriarchal authority that afforded post-Revolutionary society the ability to function politically as a united force in the service of the new republic. In reality, the United States in the years immediately following the Revolution was a confederation of individual former colonies, loosely held together by a still-forming government that faced constant threats from both internal and external forces. The narrator of Charlotte Temple first warns her female readers, her "dear girls — for to such only am I writing," against the dangers of seduction by telling them to "listen not to the voice of love, unless sanctioned by paternal approbation." 5 She follows this by imploring them to "kneel down each morning, and request kind heaven to keep

\footnotetext{
${ }^{5}$ In specifying her readership as "dear girls," the voice of the narrator here and elsewhere helps to foster an empowering sense of community for those young women within the confines of the patriarchal environment in which they lived. Ann Braude, among others, has noted the prominence of women's religious societies in influencing the experience of religion in not only women's daily lives but also men's as they raised money and undertook various causes. In the 1790s and early 1800s, for example, Braude credits the Women's Missionary Society of Oneida County for raising the money that "funded the first tour of New York State by master revivalist Charles Grandison Finney" and claims that those women had "been sowing the seeds of piety through prayer circles, mothers' meetings, and missionary efforts" long before Finney's massive "harvest of souls in 1825 and 1826" (35).
} 
you free from temptation, or should it please to suffer you to be tried, pray for fortitude to resist the impulse of inclination when it runs counter to the precepts of religion and virtue" (Rowson 26). Thus, "paternal approbation," standing in for the patriarchal authority of America's governing entity, is depicted as the first figure to which these delicate, young girls should submit themselves; failing that, they are then recommended to "kneel down" to "kind heaven" and pray for the ability to "resist" those "impulse[s] of inclination" that run "counter to...religion and virtue." Here, then, is the imaginary space opened up for female readers to envision acting upon forbidden desires and asserting their own agency. Implicit in the suggestion that they pray and resist their impulses lurks the possibility that they will choose not to pray and/or not to resist. In other words, the dangers of rebellion, seen as virtuous in so much as they helped to found the new nation, inherently imply the possibility of further rebellion against the new authority of a centralized, republican government (or a rejection of the prodigal son narrative in which the main character chooses to return, having gained a "special understanding," to a state of submission under a patriarchal authority). The unspoken and unvoiced potential for action must, therefore, be admitted in order to delineate the boundaries of the patriarchal, hegemonic necessity for female inaction, often contrary to her own desires, in the face of seduction (by dangerous influences outside of her own family or nation). If female sexuality is one of the symbolic commodities upon which patriarchal authority is built, as it is so often depicted in criticism, then men should be the ones to trade upon it; women who even attempt to do so represent the dangers of potential rebellion in the developing new republic and must accordingly be punished with abandonment and death, much as Charlotte herself is. Ironically, in Charlotte Temple, then, it is the female protagonist's textual lack of voice which best indicates her 
potential agency and thereby opens an imaginary space wherein female readers can envision their own potential acts of agency and even rebellion.

\section{III. "Lucy smiled; and Temple saw it was a smile of approbation..."-Charlotte Temple}

The tale of Charlotte Temple reminds its readers early on, by relaying the story of her mother, Lucy, that the regulation of female sexuality should be paramount to all other familial concerns. As an adolescent, Lucy's sexual potential is so valuable to one young man that it brings about the ruin and death of her entire family; each member of her family_-brother, father, and mother-sacrifices him or herself to protect Lucy's sexual purity from the advances of a wealthy youth whose "situation in life would not permit him to marry her" (Rowson 12). Despite the fact that he holds a note of debt sufficient to ruin her entire family, which he has offered to release in exchange for her acquiescence, Lucy herself never swerves from the path of ideal, virtuous womanhood. As it is portrayed in the text of the novel, she submits herself to her parents' will, does nothing whatsoever to encourage the young man, and remains pure, despite the fact that her capitulation to his desire would have rescued all of her loved ones from destitution. Her reward (and her family's) for this upright behavior is the death of her brother from a dueling wound sustained in a fight with the villain and the subsequent death of her mother from shock, followed by the imprisonment of her father in debtors' prison at the behest of her would-be seducer. Lucy supports herself and her father, still in prison, with the virtuous feminine endeavors of painting and needlework and refuses the offer of a better situation in an honorable family because it would mean abandoning her father. She remains faithful and true and cares for her father above herself in every possible way, even to the point of declaring that she hopes that they will die at the same moment so that they need never be separated. 
Eventually, Lucy's fidelity is rewarded with a worthy suitor, Mr. Temple, who manages to pay off her father's debts before he turns down a marriage arrangement to a wealthy socialite in favor of Lucy's apparently idyllic purity. The happy couple is then depicted as enjoying a life of blissful, if meager, contentment while sharing a home with Lucy's father and the only fruit of their union, daughter Charlotte.

This near-perfect existence is jarringly disrupted, however, by the budding adolescence of Charlotte. On the verge of womanhood, "at the earnest entreaty of a particular friend...[she] was permitted to finish the education her mother had begun [at home]" and leave the safety of her childhood home for Madame DuPont's school for girls (Rowson 22). Here, following a chance encounter with Montraville, a young British soldier about to depart for the war in America, Charlotte decides, after being encouraged in that direction by her guardian, Mademoiselle La Rue, to meet with him again, and thus she sets in motion a chain of events that will lead to her eventual downfall, ruin, and death. As previously mentioned, the voice of the narrator intrudes for the first time on the cusp of Charlotte's woeful decline:

Oh my dear girls — for to such only am I writing — listen not to the voice of love, unless sanctioned by paternal approbation: be assured, it is now past the days of romance: no woman can be run away with contrary to her own inclination: then kneel down each morning, and request kind heaven to keep you free from temptation or, should it please to suffer you to be tried, pray for fortitude to resist the impulse of inclination when it runs counter to the precepts of religion and virtue. (Rowson 26)

In this passage, the narrator appeals to her readers to resist the temptations of youthful desire in favor of "religion," "virtue," and "paternal approbation"; it is interesting to note that the narrator 
here defines the "approbation" as "paternal" rather than "parental," subtly suggesting that the father's role (as a representative of patriarchal authority) in the protection of his daughter's virtue is to be more valued than that of the mother's, perhaps because, being a female herself, a girl's mother may not be completely immune to the "impulse of inclination." ${ }^{6}$ Notably, this voice acknowledges the role of a woman's own conscience in making these decisions when she says, "no woman can be run away with contrary to her own inclination." This statement, made so clearly in the face of Charlotte's own upcoming ruin, seems to run contrary to the prevailing notion of that time that female sexuality must be regulated primarily by external forces such as the religious establishment, societal notions of virtue, and paternal protection. Instead, the narrator suggests that even if each of these checkpoints should fail a young woman, she should be able to maintain her own protection from ruin by virtue of her awareness of her own "inclination" and her subsequent response to that "inclination."

Lucy's story, which is told prior to this narratorial intrusion, underscores this point; for so many seemingly virtuous reasons, Lucy should have been tempted to give in to her "inclination" to rescue her family from the clutches of her wealthy pursuer by submitting to his desire. Rather, despite the extraordinarily high familial cost, she maintains her virtue and is rewarded with an idyllic life (minus, of course, her dead brother and mother). The only significant difference, then, in the outcome of her story and that of her daughter can be found in a notion of choice. For

\footnotetext{
${ }^{6}$ Presupposing the ease of a slippage between words like "paternal" and "parental," and knowing the likelihood of typesetters to make such an error, I set out to find examples of this error in other nineteenth-century editions of Charlotte Temple. While I cannot claim that my search was exhaustive, I did find that the error was never made in any of the more than fifteen different editions I managed to examine. I also discovered that this page of the text was the only one on which the word "paternal" appeared (being repeated twice within this same passage) in the entire novel. While on this search for slippage between these two words, I came across the newly published (2011) Norton Critical Edition of Charlotte Temple, edited by Marion Rust, on the Amazon.com website. Much to my surprise, one of the first reviews of that text quoted the very passage I had been examining, but the reviewer's quote used the word "parental" rather than "paternal"! Cathy Davidson's argument (quoted in full early in this chapter) that novels are works of "cultural production" can easily be seen in the differing expectations of nineteenth-century typesetters (who apparently would not have made such an error) and twenty-first-century reviewers (who apparently easily would).
} 
while Lucy had every possible virtuous inducement placed before her, she never once swerved from her righteous path, whereas her daughter, Charlotte, who had no inducement beyond simple "pleasure," as the narrator later calls it, is easily tempted to make the choices that eventually lead her down a path of inevitable demise. We can wonder, however, whether or not Lucy would have made the same choices had she been "inclined" toward her suitor's affections. Readers are led by the narrator to assume that Lucy chose the virtuous path despite all of the inducements not to do so, but they are not privy to the private, original conversation she had with him outside of her parents' hearing.

Thus, the most striking aspect of this similar notion of choice, or "inclination," between mother and daughter is the narrative means by which it is accomplished. Neither woman ever actually voices her choice; instead, her decision is related in a third-person narration told through multiple frames. Lucy's story is told by the narrator, but through the actual narrative of Mr. Temple, who, in turn, was told her story by her father, Captain Eldridge, as he sat in debtor's prison. At the start of this re-telling, Lucy sits demurely by her father's side until she is asked by him to leave the room while he relates, "some particulars which will wring my heart barely to remember," and, we know only through Mr. Temple's observation, “Miss Eldridge impressed on his cheek the kiss of filial affection and obeyed" (Rowson 9). Lucy is quite literally absent from the telling of her own story and, therefore, absent from the narrator's relating of that story to the reader. Indeed, the only direct discourse Lucy utters occurs before the recounting of her own narrative takes place when she seeks to comfort her father as he worries, "“but when I am gone, who will protect that fair bud of innocence from the blasts of adversity, or from the cruel hand of insult and dishonour"” (Rowson 8). Extreme emotion seems to simultaneously prompt and excuse Lucy as she speaks out of turn and cries out, "“Oh, my father!'...'be not anxious on that 
account; for daily are my prayers offered to heaven that our lives may terminate at the same instant, and one grave receive us both; for why should I live when deprived of my only friend"” (Rowson 8-9). Lucy's sole utterance here delineates and reflects the three-pronged nature of the regulation of female sexuality in post-Revolutionary America: "religion," "virtue," and "paternal approbation"; the development of an inner voice of feminine conscience that has internalized the messages of those authorities was the ideal means of achieving a secure and lasting regulation of female sexuality in a patriarchal culture. Lucy's mute obedience to her father in leaving his prison cell only serves to highlight the semiotic power of these three forces while at the same time suggesting her silent internalization of the message. There is, both literally and textually, no need for Lucy to speak out loud. Her inner voice of "religion," "virtue" and "paternal approbation" is clear and obvious to every reader.

Such heightened emotion as that which prompts Lucy to speak out of turn harkens back to the fervor of religious revivals in pre-Revolutionary America and illustrates the power of such emotion to lead to individual revelations of heart and thus salvation. Paradoxically, the extreme emotion which serves both to prompt and to excuse Lucy's actual utterance is also the mechanism which highlights her (unspoken) potential for agency and her latent ability to choose to do differently than "religion," "virtue," and "paternal approbation" would dictate. Butler remarks that "prerevolutionary colonial revivals allowed and even encouraged emotional outbursts as a sign of true conversion" (178). Certainly, congregations' intense emotional responses to preachers like Edwards and Whitefield have been well-documented; for example, a footnote in The Norton Anthology of American Literature's edition of Edwards' most famous sermon quotes Benjamin Trumbull's 1797 A Complete History of Connecticut's account of it: “"there was such a breathing of distress, and weeping, that the preacher was obliged to speak to 
the people and desire silence, that he might be heard"" (425). If, however, extreme emotion demonstrated true conversion, it also demonstrated the dangers inherent in allowing disenfranchised individuals to choose their own path in post-Revolutionary America. As Braude remarks, "Women... who experienced the direct intervention of God in their lives felt responsible to a higher authority than the church teachings that said they must always defer to their husbands [or fathers]" (31). Emotion, then, rather than representing the feminine weakness that "sentimental" literature is often afforded, can be read as the unspoken means of demonstrating the potential for female agency and choice.

Because potential female agency was so dangerous as a threat to patriarchal authority, its presence was coded in the lack of voice and occurrence of emotional responses in Charlotte Temple. In the re-telling of Lucy's story, only the observations, actions, and words of her father and brother are conveyed to Mr. Temple. Lucy and her mother are both seemingly in attendance merely as props in a tale about men and their familial responsibilities — a tale told by men, to other men (and yet one that is featured in a tale told by a female narrator to other women). Yet, the central truth at the heart of this story is the unseen and unspoken choice of a young girl on the eve of her sexual maturity. Readers of this narrative would know that Lucy had had direct and unimpeded interactions with her would-be seducer, Mr. Lewis, because her father tells Mr. Temple that when, "Lewis made professions of love, she confided in her parents, and assured us her heart was perfectly unbiassed in his favour, and she would cheerfully submit to our direction" (Rowson 11). The actual conversation between Mr. Lewis and Lucy is left to the reader's imagination to fill in (as is the one between Lucy and her parents-leaving readers free to question the degree to which Lucy presented her heart as "unbiased"), but the absence of it assumes common knowledge of the normative and virtuous expectations of that time. Why, 
though, when so many other aspects of the narrative are related either in great detail or else verbatim, is Lucy's own voice so notably absent from the one true act of agency she has the power to perform? Why does the presumptively female narrator choose the words of Lucy's father, brother, and future husband to speak her story, which is being upheld for the young, female readers of her tale as a model of virtue, rather than voicing Lucy's own direct, unequivocal denial as a powerful example of proper female behavior for those readers to model?

The answer to these questions can be found in the mirror-image story of Lucy's daughter, Charlotte Temple. Much as images in a mirror are reversed yet reflective of the original, Charlotte's own story mirrors but reverses many of the key elements of her mother's, most notably that of her imagined voice. For while neither woman either verbally consents to or verbally resists her own seduction in the depiction of her story in the text of Charlotte Temple itself, both women nonetheless perform acts of incontrovertible, albeit unvoiced, agency in dealing with her seducer. Indeed, the didactic positioning of the novel as a whole assumes the young, female reader does have the ability to choose not to fall prey to the designs of artful young men like Montraville. Thus, we must also assume that Lucy chooses the moral path of virtuous denial in bringing the matter before her parents (regardless of what we may believe about the state of her own feelings) whereas Charlotte chooses its mirrored-reverse: acquiescence to or complicity in her own seduction. So, either woman's choice, morally acceptable at the time or not, functions as an imaginative model for agency for female readers of Charlotte Temple.

To be sure, despite Lucy's portrayal as a paragon of moral ideals, the text does offer a small space from which readers can connect Lucy's ability to make choices with a concurrent development of her individual ability to form and experience desires. As previously noted, readers are left to wonder how truly "unbiased" her heart was in Mr. Lewis's case; Lucy's lack 
of voice in this telling could either be indicative of her lack of "inclination" towards him or it could show a lack of ability to form desires on her part because she had yet to reach that point in her adolescent development and subsequent maturation. However, by the time Lucy is introduced to Mr. Temple, readers no longer have to wonder about such things. Mr. Temple does not go to Lucy's father with his dreams of the future, as would have been proper, but instead he makes overtures directly to her, and his side of this conversation is voiced in the text of Charlotte Temple. He says to her, outside of her father's hearing, "We will purchase a little cottage, my Lucy,' said he, 'and thither with your reverend father we will retire... and viewing the serenity of your countenance, [he will] feel such real pleasure dilate his own heart, as shall make him forget he had ever been unhappy"” (Rowson 21). In keeping with the lack of voice inherent in the expression of desires in this novel, Lucy does not reply to Mr. Temple in words: "Lucy smiled; and Temple saw it was a smile of approbation" (Rowson 21). Thus, Lucy's act of smiling a "smile of approbation" indicates her desire for Mr. Temple and a life with him. Even after this, the couple is not shown going to Lucy's father for his "paternal approbation"; instead, the very next sentence is: "He [Mr. Temple] sought and found a cottage suited to his taste; thither...the happy trio retired; where, during many years of uninterrupted felicity, they cast not a wish beyond the little boundaries of their own tenement" (Rowson 21). The reward for Lucy's act of agency, in smiling her desire to be with Mr. Temple, is a happy marriage; she could have chosen an equally virtuous and potentially contented existence if she had taken up the offer of "friends" to live with them when given the chance, but she did not. Her own "inclination" played a significant role in her decision to wed Mr. Temple, and her father's "paternal approbation" is notably absent from this portion of the text. Thus, action is paradoxically valued over voice in the story of Charlotte Temple; the mandates of "religion," "virtue," and "paternal 
approbation" serve to open a space wherein female desire may be indicative of the development of selfhood despite their seemingly controlling presence.

It is interesting to note the possibility that the very fact of Charlotte's existence could also signify Lucy's ability to form desires and thus belie the depiction of her as the quintessence of what the narrator calls the ideal, "lovely Virgin...[whose] handmaids are Humility, Filial Piety, Conjugal Affection, Industry, and Benevolence" (Rowson 32). As a married woman, Lucy could not maintain this idealistic state, as the narrator attributes its joys and rewards as applicable only to virgins. Lucy must have given in to her own "inclination" at least one time in her marriage, or Charlotte would not have been born. "Pleasure is a vain illusion; she draws you on to a thousand follies, errors, and I may say vices, and then leaves you to deplore your thoughtless credulity," the narrator informs her readers (Rowson 32). Whether Lucy's pleasure was her own or simply a wish to please her husband, she is clearly no longer a virgin; her desire, and her choice to act on that desire, even within the bounds of marriage, shows a development of agency that could have been considered threatening. Immediately following the extraordinarily brief depiction of her happy marriage, the section on Lucy's life ends with these words: "Such were the parents of Charlotte Temple, who was the only pledge of their mutual love, and who, at the earnest entreaty of a particular friend, was permitted to finish the education her mother had begun, at Madame $\mathrm{Du}$ Pont's school, where we first introduced her to the acquaintance of the reader" (Rowson 22). So, the narrator moves directly from a description of Lucy's happy life to an abrupt reminder of her current heartache, as the reader is already well aware of Charlotte's situation. The message here is that, even when contained in the religiously sanctioned and societally acceptable bounds of marriage, female desire and sexual pleasure, read here as an indication of that woman's potential to make choices, always has an attendant consequence; in this case, Lucy's choice leads to the 
birth of a daughter already tainted by the original sin of her mother. The novel is able, though, to contain carefully that pleasure for its young, virginal readers within the vicarious, imaginary experiences of the book, allowing them to explore safely their own "inclinations" and desires and thereby begin to imagine their own abilities to act as they would choose, but without all of those consequences coming to bear upon them in reality.

\section{IV.““Alas! My torn heart!' said Charlotte, 'how shall I act?'”-Charlotte Temple}

Not one of Charlotte's choices in Charlotte Temple is directly written as though it is an independent decision she makes on her own. Rather, she is depicted, at first glance, much as Nina Baym described, as a helpless, young creature with little or no seeming will of her own, constantly torn between her immoral teacher's (Mademoiselle La Rue) dubious suggestions and those of her seducer, Montraville, on one side and her parents', Madame Du Pont's, and her grandfather's sage advice on the other. Her declarations, both voiced and thought in the text of the novel, are never considered by those with whom she interacts to be the final word in any potential decision; indeed, Charlotte seems to second-guess herself at every turn, and her seducer and his accomplices are only too happy to encourage this rhetorical flip-flopping and thereby to take advantage of it and of her. Quite significantly, however, Charlotte's own actions are what initiate the first contact between her and Montraville, and, without them, her whole story may have never needed to be told: “...Madame Du Pont, at the head of her school, descended from the church. Such an assemblage of youth and innocence naturally attracted the young soldiers: they stopped; and, as the little cavalcade passed, almost involuntarily pulled off their hats. A tall, elegant girl looked at Montraville and blushed: he instantly recollected the features of Charlotte Temple, whom he had once seen and danced with at a ball in Portsmouth" (Rowson 3). In other 
words, Charlotte already knows Montraville and chooses to look at him long enough both to catch his attention and then to blush when he looks her way; this scene takes place on the very first page of the text, prior to the relation of her mother's story. Charlotte's own deliberate act thus sets the entire plot in motion. In several other small but considerable ways as the plot progresses, Charlotte's actions, rather than her verbal acquiescence, continue to further the likelihood of her own seduction.

Throughout the narrative of her seduction, it is these direct actions of Charlotte's rather than her words that point toward her desire as the motivating force behind her choices, and it is this same desire that indicates her development of an ability to make those same choices on her own behalf. For example, when Montraville first tracks Charlotte down after the above incident, he slips a letter into her hand; she could have chosen not to read the letter or she could have given it to her guardian, La Rue, to look at first and judge its appropriateness. Charlotte seems to know she should not directly view the letter, but she also does not seem to want to do anything to lose definitively the chance of fulfilling her desire to look at it. Much like a blush of passion or a lover's caress, Charlotte's countenance is depicted by the narrator as touched by a "gentle suffusion of vermillion [that] tinged her neck and face," as she says to La Rue, "“he gave me this letter; what shall I do with it?"' (Rowson 28) La Rue, who wishes to see Charlotte seduced for her own immoral designs, replies, "Read it, to be sure"” (Rowson 28). Charlotte objects, “"I am afraid I ought not,' said Charlotte: 'my mother has often told me, I should never read a letter given me by a young man, without first giving it to her'” (Rowson 28). So, we know that Charlotte is fully aware of the proper course of action that she should be taking. The conversation continues: “'Lord bless you, my dear girl,' cried the teacher smiling, 'have you a mind to be in leading strings all your life time. Prithee open the letter, read it, and judge for 
yourself; if you show it your mother, the consequence will be, you will be taken from school, and a strict guard kept over you; so you will stand no chance of ever seeing the smart young officer again"” (Rowson 28). Here, La Rue encourages Charlotte to think for herself, not to "“be in leading strings,"' like a small child, which acknowledges Charlotte's developing capacity for agency as commensurate with her development of desire. Charlotte pauses to think this over and gives an answer that will both satisfy her conscience and still afford her the appearance of making her own disinterested decision on the matter: "“I should not like to leave school yet...till I have attained a greater proficiency in my Italian and music. But you can, if you please, Mademoiselle, take the letter back to Montraville, and tell him I wish him well, but cannot, with any propriety, enter into a clandestine correspondence with him.' She laid the letter on the table, and began to undress herself" (Rowson 29).

At this precise moment, when she would seem to be certain in her voiced decision not to allow a correspondence with Montraville, Charlotte's actions once again belie the validity of her words: she undresses herself as she speaks. In so doing, she may seem on the surface to be merely readying herself for bed, but in all reality she is acknowledging her underlying sexual desire by readying herself for Montraville's bed while simultaneously and literally allowing herself to appear more vulnerable to the machinations of La Rue by taking her clothes off. La Rue pounces on the opportunity Charlotte offers her in this moment by suggesting that Montraville has several unattractive physical attributes that are the basis for Charlotte's rejection: “"I think he is marked with the small pox,"” she says, and, “"His eyes... are grey and want expression,"' she claims (Rowson 29). In pointing out the physical features of Montraville at a time when Charlotte's own are on display, La Rue gives Charlotte an opportunity to reflect on those features while her own body is actually exposed. Charlotte leaps to Montraville's defense, 
declaring, "'he has a remarkable clear skin and fine complexion,"” and that his eyes are "'the most expressive...I ever saw"” (Rowson 29). “"Well, child,"” says La Rue, “"whether they are grey or black is of no consequence: you have determined not to read his letter; so it is likely you will never either see or hear from him again.' Charlotte took up the letter" (Rowson 29). And so Charlotte's act of picking up the letter, while undressed, overrides her previous verbal decision not to communicate with Montraville. She chooses to further the likelihood of her own seduction by continuing to allow her actions to supplant her words: “"At any rate I am determined not to answer it,' continued Charlotte, as she opened the letter" (Rowson 30).

The narrator chooses to interrupt the action of the plot with her own voice at this specific moment, and she directs her comments at the readers of this novel; however, she does not remark on either Charlotte's words or her actions. Instead, she explains the motivations and manipulations of La Rue, claiming that “...when once a woman has stifled the sense of shame in her own bosom, when once she has lost sight of the basis on which reputation, honour, every thing that should be dear to the female heart, rests, she grows hardened in guilt, and will spare no pains to bring down innocence and beauty to the shocking level with herself: and this proceeds from that diabolical spirit of envy, which repines at seeing another in the full possession of that respect and esteem which she can no longer hope to enjoy" (Rowson 30). By choosing to comment on La Rue's actions and motivations rather than Charlotte's, the narrator here opens a space in which her readers can both excuse Charlotte's behavior and still continue to take vicarious pleasure in it. Much as Charlotte herself could have chosen to set Montraville's letter down and never take it up again, readers of her story could easily have chosen to do the same with the novel. The narrator's voice, then, works in tandem with La Rue's to give the readers a reason to defend Charlotte, to pity her, and, ultimately, to take pleasure in her actions and the 
telling of her tale without endangering their own actually virtuous states —although their imaginary ones may have been at issue. Furthermore, the narrator does not directly relay to her readers the resultant conversation between Charlotte and La Rue so that those readers may be spared the experience of hearing Charlotte actually voice her decision to see Montraville; instead, the narrator states that "...it was determined that she [Charlotte] should meet with Montraville the ensuing evening" (Rowson 20). The readers' knowledge of Charlotte's decision is thus removed from the direct experience of witnessing her making or voicing it. Readers may therefore experience the vicarious pleasure of such a forbidden decision without being subject to the taint of actually seeing her make it; their virtue is spared any direct witnessing in the discourse of the plot, leaving them the pleasure of imagining an experience of desire. The narrator similarly enjoys the satisfaction of telling this tale without sullying her own position as a voice of maternal approbation by placing the blame for Charlotte's downfall on La Rue rather than on Charlotte herself.

After this point, Charlotte's seduction is portrayed by the narrator as inevitable. Even though Charlotte considers the possibility of not meeting Montraville- - "Several times did she almost resolve to go to her governess [Madame Du Pont], show her the letter, and be guided by her advice" - the narrator explains that "Charlotte had taken one step in the ways of imprudence; and when that is once done, there are always innumerable obstacles to prevent the erring person returning to the path of rectitude: yet these obstacles, however forcible they may appear in general, exist chiefly in imagination" (Rowson 35). The fact that the "obstacles" to virtuous behavior "exist chiefly in imagination" only serves ironically to highlight the fact that the encouragements for acting upon desire "exist chiefly in imagination" as well. In enabling those imaginative encouragements, the novel invites readers to experience them vicariously while also 
assuring them that the consequences of so doing will also be contained within that same realm of fancy.

Therefore, the novel actually fosters the development of an ability to imagine one's own potential to act immorally which serves to signal the potential for developing selfhood. Still, the narrator seeks to excuse Charlotte's behavior, and thereby her own telling of it, at every possible turn. For example, she tells her readers that "Charlotte had, when she went out to meet Montraville, flattered herself that her resolution was not to be shaken, and that, conscious of the impropriety of her conduct in having a clandestine intercourse with a stranger, she would never repeat the indiscretion." That Charlotte is unable to stick to her resolve to tell Montraville that she cannot see him again comes as no great surprise for the readers or for the narrator because Charlotte's actions and choices have belied her professed voice at nearly every turn.

Nevertheless, the narrator states, "But alas! poor Charlotte, she knew not the deceitfulness of her own heart, or she would have avoided the trial of her stability" (Rowson 37).

Charlotte's "heart" is thus given the power to make the decision to see Montraville again; her virtuous soul and considerate mind are no longer able to override her heart's desires. This power of the "heart" is reminiscent of the extreme emotional responses of religious revivalists who sought a "change of heart" and saw it as the mark of "true conversion." "True conversion" for Charlotte is her transformation from existing merely as the object of her parents' affection and wishes to a starting to become a subject in her own right. The contradiction between her virtuous words and her heart's deeds is what allows Charlotte to seem textually disenfranchised from an ability to choose to be seduced while at the same time affording her the capacity to perform the actions that set that seduction in motion. The non-voicing of Charlotte's choice affords her readers the imaginative space in which to envision vicariously actions of their own 
that could lead to sexual pleasure without immediately facing the unfortunate consequences that Charlotte must.

Not having to voice in actuality Charlotte's desires is Charlotte Temple's narratorial means of depicting her as a sweet, trusting, and innocent child to whom its readers can relate. It is, paradoxically, this connection between Charlotte and her female readers that allows them to simultaneously imagine themselves as a subject in much the same way that Charlotte is beginning to be. In other words, the portrayal of Charlotte as what Baym termed "man's inevitable dupe and prey" is the very mechanism by which readers can also imagine themselves as potential ethical subjects who must make choices and act upon themselves as subjects. For example, when Charlotte drives off with her seducer, Montraville, to meet the ship that will take her, significantly, to America (and to her eventual death in childbirth), she is lovingly spared the cruel torment of actually voicing a willingness to go with him, and thereby directly betraying her parents and her own sense of virtue, by Montraville himself. Prior to this last meeting, Charlotte had resolved not to have any more interaction with Montraville; she tells him, "'I am come to take an everlasting farewel"' (Rowson 48). Once again, the narrator avoids textually relating the subsequent conversation: "It would be useless to repeat the conversation that here ensued; suffice it to say, that Montraville used every argument that had formerly been successful, Charlotte's resolution began to waver, and he drew her almost imperceptibly towards the chaise" (Rowson 48). Charlotte responds to this action by saying, "“I cannot go...cease, dear Montraville, to persuade. I must not: religion, duty, forbid"” (Rowson 48). However, despite this proclamation, she does not actually walk away; her actions once again belie her words, and she is spared the need to voice her true desires. In her inaction, then, lies her choice, her action. Charlotte's naming of "religion" and "duty" as her reasons for not going with Montraville, rather than a 
dislike of him, further betrays her own "inclination." So, Montraville counters, “"Cruel Charlotte...if you disappoint my ardent hopes, by all that is sacred, this hand shall put a period to my existence. I cannot—will not live without you"” (Rowson 48).

This moment, then, when Montraville threatens to take his own life if he cannot have Charlotte, is the pivotal moment of the entire story. Everything that has happened prior to this has led up to it; everything that will happen after this will be a result of it. It appears that she must actually make, and voice, a decision. She must finally deal with her own development as an ethical subject who can choose to act upon herself rather than continuing to avoid a direct, conscious confrontation with that development as she has previously done. In this moment, then, Charlotte's heart and her inclination are at an impasse with her religion and her duty: “"Alas! my torn heart!' said Charlotte, 'how shall I act?'” But Charlotte does not need to speak her wishes directly because, as both she and her readers surely know, her hesitation and inaction have provided the opening for her to act on her true desire. Montraville also knows this: "'Let me direct you,' said Montraville, lifting her into the chaise. 'Oh! my dear forsaken parents!' cried Charlotte. The chaise drove off. She shrieked, and fainted into the arms of her betrayer" (Rowson 48). This scene, while seemingly devoid of action to modern readers who would want Charlotte to do more than simply faint, was not actually empty of either heartfelt passion or action for contemporary readers. Charlotte does not just faint; she shrieks and then faints directly "into the arms of her betrayer"; she is not sobbing quietly or sinking limply to the ground in the face Montraville's pleas, and she is not attempting to run from him or jump from his arms. Instead, the force of her desire causes her to shriek and faint directly into the arms of her future lover. Montraville is no rapist, and nowhere in the narrative is he portrayed as such. 
So, readers are free to imagine Charlotte plunging herself into his arms as she "faints" and him consoling her with ardent kisses as the chaise speeds away.

Significantly, Charlotte does not either leap from the chaise or cry out in concern for herself, but instead she worries about her "forsaken parents" as she faints "into the arms" of her now lover, Montraville. Herein, then, female readers of Charlotte Temple are invited by the narrator to embrace vicariously their own possible agency and decide whether or not, given the opportunity, they would walk the path chosen by Charlotte. The vicarious pleasures of seduction, desire, and choice are able to be safely explored by female readers without risking any actual harmful consequences or endangering the patriarchal authority of "religion," "virtue," and "paternal approbation" because the narrator safely couches the entire tale within the guise of a didactic narrative seemingly designed to guard against the very choices it imaginatively depicts as pleasurable and powerful. And yet, women of this time may have defined themselves almost entirely in terms of their relationships - with their parents, siblings, friends, and, eventually, husbands and children. So, imagining forsaking one's parents, whether as a moral transgression as Charlotte did or in a socially-acceptable marriage, marks a time of uncertainty for any young woman who must then face the worrisome future in which those relationships have yet to be firmly established and in which ethical choices will need to be made. Nonetheless, the depiction, even if indirectly done, of budding female agency in novelistic discourse in late-eighteenthcentury popular fiction was a significant development, and one that I contend shows the potential for women to begin to form themselves as ethical subjects with the capacity to choose whether or not to act upon their developing desires.

This interpretation of Charlotte Temple suggests that normative Protestant codes hinted at therein are being employed in a way that is antithetical to their stated aims because ostensibly a 
culture firmly ensconced in establishment Christianity would have neither endorsed nor encouraged the type of free will required for women to choose to act morally or not. Indeed, Charlotte Temple's generalized references to "God" and "prayer" serve to underscore the tensions between religious institutions and revolutionary ideals. In other words, during and immediately following the time of establishment religion in the late eighteenth century, I believe that such novels as Charlotte Temple express little direct or explicit concern with specific religious doctrines because the turmoil of the Revolution and subsequent Constitutional disestablishment of religion threw that culture into a state of chaos wherein the clash arose that Butler suggested. Nevertheless, novelistic works of that time do comment on that uncertainty and on the tensions between what Butler called "denominational authority" and "the egalitarian values of the American Revolution" (268). While white, male leaders of the new nation were quite literally writing the moral and legal codes by which they would choose to govern, Charlotte Temple clearly illustrates that the arenas in which an ethical subject could choose to sublimate or act upon her own desire are extremely limited for Charlotte and her female readers at that point in history. Charlotte's readers could imagine, vicariously, what they might do if they could rely on such a self and thus choose for themselves whether or not to act according to society's moral codes. For Charlotte's readers, the temptation to act against patriarchal authority is contained within the novel by the very fact of the novel's merely imaginative existence. For Charlotte herself, the consequence of her actions must be death, which is for her character the only viable means of containment and, ultimately, salvation. Despite this destructive ending, what is significant about Charlotte Temple, in that uncertain, chaotic, post-Revolutionary world, is simply that the imaginative possibility could exist and begin to develop in the subjective minds of female readers. 
Thus, Charlotte's dying does not negate the power of her example for her readers. Unlike some seduction novels, Charlotte's death is not directly caused by childbirth nor does her child die with her. Charlotte's health declined long before she actually gave birth, and she is able to hold on for three days between the birth of her daughter and her own death. Those three days can be read as having Christian overtones that would correlate to the time between Christ's death and His resurrection. Charlotte's earthly "death" actually occurs when her shame and ruin is confirmed by the live birth of her daughter, but she is spiritually redeemed after three days when her father arrives and offers her his forgiveness before her actual physical death. Her ultimate salvation is related at the moment of her death when the narrator presents this description: "a sudden beam of joy passed across her languid features, she raised her eyes to heaven - then closed them for ever" (Rowson 127). So, despite her physical death, a truly repentant Charlotte is saved and offered her heavenly reward. Charlotte's actions are also valorized for the reader by the suffering and/or deaths of all of her primary betrayers and tormentors: Montraville, Belcour, and La Rue. Montraville is described as living an angst-ridden existence once he realizes what has become of poor Charlotte; he endures a "dangerous illness and obstinate delirium...during which he raved incessantly for Charlotte...He recovered; but to the end of his life was subject to severe fits of melancholy, and while he remained at New-York frequently retired to the churchyard, where he would weep over the grave, and regret the untimely fate of the lovely Charlotte" (Rowson 130). Belcour, who truly acted with malice towards Charlotte, subsequently dies when Montraville learns of Charlotte's death, and, "remembering the perfidy of Belcour, flew like lightning to his lodgings...they fought, and the sword of the latter entered the heart of his adversary" (Rowson 130). Mademoiselle La Rue had married Colonel Crayton, captain of the ship that brought Charlotte to America, but suffered for years due to her own evil ways, and "had 
been separated from her husband seven years, the chief of which she had passed in riot, dissipation, and vice, till, overtaken by poverty and sickness, she had been reduced to part with every valuable" (Rowson 132).

However, because they show themselves to be truly repentant, Montraville and La Rue are offered a kind of forgiveness by Mr. Temple, who, upon reflection, can be seen to stand as a representative of Christ's potential salvation and forgiveness in several key moments of the story. After all, he was the emotional and financial salvation of Lucy and her father and, of course, the means of redemption for Charlotte. Furthermore, he offers forgiveness to the two people who take responsibility and express remorse for their parts in Charlotte's fall and death, Montraville and La Rue, but he fails ever to forgive the one unrepentant soul, Belcour. When Montraville stumbles upon Charlotte's funeral procession, he asks a bystander "who it was that was just buried." The man tells him that it was "“a poor girl that was brought from her friends by a cruel man, who left her when she was big with child, and married another."' Montraville runs to the graveside in anguish and cries, "If thou art the father of Charlotte Temple...I am Montraville.' Then falling on his knees, he continued-'Here is my bosom. I bare it to receive the stroke I merit. Strike—-strike now, and save me from the misery of reflexion"” (Rowson 129). Mr. Temple refuses to harm him, but instead tells him, “"if thou wert the seducer of my child, thy own reflexions be thy punishment. I wrest not the power from the hand of omnipotence. Look on that little heap of earth, there hast thou buried the only joy of a fond father. Look at it often; and may thy heart feel such true sorrow as shall merit the mercy of heaven"” (Rowson 130). As a representative of Christ's forgiveness, Mr. Temple does not attempt to seek his own revenge upon Montraville, but instead offers him a path towards the possibility of redemption by “"the hand of omnipotence." Perhaps finally acknowledging his 
own role in Charlotte's demise and avenging her by killing Belcour is what allows Montraville to continue his happy marriage to Julia. Similarly, the last depiction of La Rue ends with her begging Charlotte's parents for forgiveness before her own death when she shows up on their doorstep ten years later: "“I am the viper that stung your peace,"” she tells them, drawing upon religious imagery of the snake in the Garden that tempted Eve. "'I am the woman who turned the poor Charlotte out to perish in the street. Heaven have mercy! I see her now,' continued she looking at Lucy [Charlotte's now ten-year-old daughter]; 'such, such was the fair bud of innocence that my vile arts blasted ere it was half blown,"” La Rue admits. Yet, La Rue is redeemed in her own way by her suffering in coming to realize her sins in her final days: "I have fasted,' said she, 'two days, and last night lay my aching head on the cold pavement: indeed it was but just that I should experience those miseries myself which I had unfeelingly inflicted on others." La Rue dies shortly after this, but not before receiving a kind of forgiveness from Mr. Temple, who once again stands in as a representative of the mercy possible from both an earthly and a heavenly father: "Greatly as Mr. Temple had reason to detest Mrs. Crayton, he could not behold her in this distress without some emotions of pity. He gave her shelter that night beneath his hospitable roof, and the next day got her admission into an hospital; where having lingered a few weeks, she died, a striking example that vice, however prosperous in the beginning, in the end leads only to misery and shame" (Rowson 132). Those are the final words of the novel.

Despite the apparent impact of those last words, the fact that Charlotte's daughter does not die along with her is significant and partially contradicts the self-proclaimed, overarching, didactic message of the novel. The message that women have no power to act on their desires without risking death, "misery, and shame" is belied by the outcome of Charlotte's act of desire. The direct physical result of Charlotte's desire and the choices she made to act on it is her 
daughter. Had the girl died, then Charlotte's story would have had no redemptive life to live on after her own death — the message would have been clear: female defiance of patriarchal authority equals total ruin and death. Instead, Charlotte is forgiven, presumably goes to heaven, and her daughter lives, and Rowson goes on to write another novel about that child's life many years later. In that novel, Lucy, as the girl is named, grows up to be a beautiful, charitable, benevolent creature who never marries but instead lives her life entirely in the service of others. Because Lucy never marries, she is able to maintain that pure and virginal state that neither her mother nor her namesake grandmother had been able to preserve. When she dies, the narrator writes,

When the summons came, which released her pure spirit from its earthly tenement, and the history of her family was closed with the life of its last representative; those who had witnessed, in her mother's fate, the ruin resulting from once yielding to the seductive influence of passion, acknowledged, in the events of the daughter's life, that benignant power which can bring, out of the most bitter and blighting disappointments, the richest fruits of virtue and happiness. (Rowson Lucy Temple 265)

The actual "richest fruits of virtue and happiness" to which I believe Charlotte's story and her daughter's birth speak is the potential ability for young women to develop agency concurrent with their development of desire. Lucy's death as a childless, unmarried woman serves two purposes, then. First, it allows for a surface-level kind of redemption for all of the female members of the Temple family, wherein their previous actions are rectified by the incredibly virtuous life of its last living member. This also reinscribes the societally acceptable functions of "religion," "virtue," and "paternal approbation" for readers, allowing them to feel at once safe 
from temptation while still imaging the ability to act on those temptations. Second, it still validates the notion that a capacity for desire indicates a potential capacity for action; Lucy never married and still lives an apparently fulfilling life, which offers female readers some hope for a life outside of marriage, but at the same time the fact that she never experiences that kind of desire would suggest that she is incapable of veering from the path set forth for her by both religious and patriarchal authority and so making choices on her own. Indeed, Lucy seems unable to act or feel on her own behalf. After a friend's wedding, the narrator informs us that "None seemed to enjoy the day more deeply and feelingly than Lucy. She had learned the great secret of woman's happiness, to enjoy the happiness of others. Selfish gratification was no concern of hers" (Rowson 260). In fact, the only near-desire experience Lucy has during the whole novel is an almost engagement to her own half brother, Montraville's legitimate son from his marriage to Julia. Her temptation is not really a temptation, therefore (as the relationship between them was brought to light before any marriage could take place), and she is able to reinscribe her feelings within the proper bounds of sibling affection. For Charlotte Temple's readers, her example of action affords them the ability to begin to develop ethical subjects and thereby imagine their own potential agency.

\section{Conclusions}

In a society founded on egalitarian principles but functioning according to patriarchal authority, women in post-Revolutionary America were not usually able to experience or act on their own desires in a way that could be reconciled with their subjugated place in the world. In the imaginative realm of novelistic discourse, though, those desires can be explored safely through vicarious pleasure. Seemingly kept at bay by societal safeguards like "religion," 
"virtue," and "paternal approbation," female desire appears, in a novel such as Charlotte Temple, to serve as a warning sign to young, female readers by cautioning them to work assiduously to avoid the fate of death and ruin ostensibly being modeled by its heroine, Charlotte. In contextualizing Charlotte's behavior within the codes of normative Protestant theology, however, the intersection of those safeguards with the depiction of female desire in Charlotte Temple, rather than securing the continued purity and subjugation of female readers, actually serves to open an imaginary space wherein they can begin to envision the possibility of acting on their own desires. What Charlotte actually models for female readers is the complicated social and familial navigations that the formation of "a relationship with the self" may require. Thus, the cultural significance of Charlotte Temple lies in its ability to point towards the potential for women to develop a sense of agency and a capacity for self determination in their own lives and realities. That is the reason it was read in late-eighteenth-century America, and that is the reason it remained popular throughout the nineteenth century. How that potential developed and matured in other novelistic works will be the subject of further exploration in later chapters of this study. 


\section{Chapter Two: \\ In Her Own Words: Speaking Selfhood in The Coquette}

\section{Introduction: "An unusual sensation possesses my breast..."—The Coquette}

Published only three years after Charlotte Temple and rivaling it for quite some time in popularity, Hannah Webster Foster's epistolary novel, The Coquette, furthered the possibility of developing selfhood and agency for its female readers by allowing them to imagine their own ability to voice directly their desires as the novel's protagonist, Eliza Wharton, does. From the very first line of the first letter in the novel, Eliza voices her rebellious desires: "An unusual sensation possesses my breast; a sensation which I once thought could never pervade it on any occasion whatever. It is pleasure [emphasis Foster's]; pleasure, my dear Lucy, on leaving my paternal roof" (Foster 5). Eliza claims that she "was before unconscious of possessing" this awareness of pleasure. In expressing it, she indicates that she now has a conscious awareness of her own desires and, concurrently, a realization that she need not be bound any longer by what she calls an "implicit obedience to the will and desires of [her] parents" (Foster 7). Instead, she may choose to leave her "paternal roof" and pursue her own "pleasure."

The character of Eliza represents a crucial step in the imaginary, novelistic development of female selfhood and agency: the actual ability of a female character to voice and to be consciously aware of her own desires, unlike Charlotte Temple who is portrayed as either unable or unwilling to voice or to be fully conscious of her own desires or their implications. It is important to note that Eliza's desires are not necessarily sexual—she desires the pleasures of freedom — but they threaten the normative patriarchal system just as surely as a woman's overt sexual desire would. So, the direct voicing of that conscious realization must come at a steep price for Eliza. In order to contain safely the now explicitly-voiced danger of female desire so 
that it cannot threaten patriarchal authority overtly, the consequences must be much more direct and less redemptive than those which Charlotte Temple experienced.

Marion Rust contends that The Coquette "gives brilliant voice to how the early American obsession with self-determination felt from the point of view of one whose straitened circumstances made control of her destiny rather difficult" (85). ${ }^{1}$ Cathy N. Davidson makes a similar remark regarding Eliza’s desire to determine her own fate: "Eliza naively sought to exercise her freedom only to learn that she had none" (Introduction xvii). While I would dispute the idea that Eliza is naïve about her lack of freedom (after all, Eliza not only expresses knowledge of her own social and economic limitations, but she is also reminded of them by several people over the course of the novel), I agree nonetheless with both Rust's and Davidson's overall points about the options available for women at that time. Other critics have expressed much the same sentiment with regards to both Eliza specifically and the situation of women in general in post-Revolutionary America. Elizabeth Barnes argues that political authority was reconceived in the new nation as "a republican vision of voluntary obligation to which all citizens [were] bound" that required "consent as a precondition for government"; however, she argues that although this may have substantially altered the affiliations between those citizens recognized as "“free and equal' individuals, ... it clouded the issue for those who could claim neither legal nor economic independence" (66). Similarly, Ivy Schweitzer considers the emerging ideal of friendship as the basis for marriage in the new republic and asserts that crucial distinctions should be recognized "between friendship and marriage as consensual relations"; she contends that "“rational equalitarian friendship' was a form of affiliation...that historically

\footnotetext{
${ }^{1}$ Rust describes Eliza as, “the sprightly protagonist of Hannah Foster's The Coquette - the decade's second-bestselling novel, after Charlotte Temple"; then, she argues convincingly that Eliza Wharton was "precisely the kind of woman" who would have read Charlotte Temple (77). In fact, the September 20, 1788 edition of the Massachusetts Centinel reported that the real-life version of Eliza Wharton, Elizabeth Whitman, "was a great reader of novels and romances" (Curiosos).
} 
excluded women or limited their participation on the basis of their alleged emotionalism, while 'consensual marriage' in this era, no matter how affectionate and voluntarily embraced, did not consider or render the spouses legally or socially 'equal"' (104). ${ }^{2}$

I concur with these readings and others of the same ilk about the non-egalitarian status of certain types of relationships in post-Revolutionary America and their political functionality as the local objects of the exercise of early-national patriarchal authority. Therefore, I do not find it necessary to re-analyze the positioning of women in the political, legal, or economic realms in order either to counter or assert their status in the new republic because so many fine scholars have already focused on that work. Rather, I acknowledge the subjugated position of women at that time and in that place. In fact, I believe that it paradoxically fostered the imaginative development of female selfhood and agency that I think seeped into that early-national consciousness, and, in so doing, encouraged a female agency that was almost always self destructive. At later points in antebellum American cultural and novelistic history, this would become the preliminary basis for women to begin to develop productive selves that would not require their own demise.

Whereas critics like Rush, Davidson, Barnes, and Schweitzer locate the struggle for an emerging female consciousness in political, legal, or economic discourses, I focus instead on the place of religious discourse in this conversation. If we look beyond the politics and economics of patriarchal authority, we can see the primacy of religious discourse in that society as it takes on the paradoxical role of both subjugating and encouraging female agency in these texts. Much as reading the Bible could assist a sinning individual in learning how to exercise his/her will in ways that did not incur God's wrath, reading a novel like The Coquette could encourage in

\footnotetext{
${ }^{2}$ Schweitzer positions her argument in relation to Jay Fliegelman's definition of republican marriage: “The struggle for American independence and for subsequent federal union was intimately related to, and ideologically reflected in, a national affirmation of the sacred character of affectional and voluntaristic marriage" (129).
} 
readers an awareness of their own potential agency while simultaneously teaching them to exercise it carefully. Therefore, as limited and limiting any reading of an American novel written by a woman for female readers in the years of early nationhood must necessarily be, it is productive to reexamine the ways in which narrative models of selfhood and agency, particularly when they rely upon contemporary religious discourse (and regardless of their punishing outcomes), can be read as vicarious, imagined pleasures that can thereby model potential positions of empowered self formation and expanded agency upon which later novels could build. The model of self understanding that these texts demonstrate for their readers relies upon a theological reading of the world in which all choice takes on the moral form of potential salvation or damnation. The choice of whom to marry is depicted as the ultimate salvation analogy in which marrying well is redemptive whereas marrying poorly results in a lifetime of suffering. The epistolary form forefronts the conscious struggle of the protagonist as she grapples with her marriage options. Epistolary seduction tales make that experience more accessible to readers and afford them a mimetic understanding of that struggle.

\section{Epistolarity and Religious Discourse}

The imaginative development of female agency progresses most significantly in The Coquette beyond that of Charlotte Temple due to the form of the novel as an epistolary work. In such a work, readers are privileged with the direct voices of its letter writers, which afford them a more mimetic reading experience rather than merely a diegetic one. As Janet Gurkin Altman explains, "the basic formal and functional characteristics of the letter, far from being merely ornamental, significantly influence the way meaning is consciously and unconsciously 
constructed by writers and readers of epistolary works" (4). ${ }^{3}$ This paradox is seen at work particularly in The Coquette when considering what Altman names as "elliptical narration [emphasis hers]" in which many "narrative events may be nonnarrated events of which we see only the repercussions" (207). ${ }^{4}$ These acts of communication, indeed the very voice of Eliza as she writes and thereby enacts actual communication, are at the heart of this text's ability to model for female readers a space in which they can begin to imagine their own acts of voicing their own desires and thereby developing a fledgling sense of agency.

The notion of elliptical narration is further complicated in The Coquette by the fact that Eliza is a thinly-veiled, fictional portrayal of the real-life person Elizabeth Whitman, which lends additional weight to her character's voice within the novel itself, but which also works to further the paradoxical dichotomy between the reader's mimetic and diegetic experiences. Most readers of The Coquette would have been well aware of the "narrative events" of Elizabeth Whitman's life story; those are not the events that would have needed to have been "narrated," and, indeed, the novel does not narrate the actual acts of Eliza's seduction, her labor and delivery, or her death. By the time The Coquette was published in 1797, Elizabeth Whitman's life and her sensational story had already become part of popular culture. Following her death in July 1788 after giving birth to a stillborn child at an inn in Danvers, Massachusetts, Whitman's story was published in numerous newspapers as a kind of cautionary morality tale. For example, on

\footnotetext{
${ }^{3}$ Such an interpretation of the function of epistolary fiction underscores the importance of the place of the reader in constructing meaning therein. Altman specifies the "multivalency" of letters- "as a linguistic phenomenon, as a real-life form, as an instrument of amorous or philosophical communication"- as a unique genre, one which allows epistolary novels to "make meaning in a variety of ways" (4-5). Most notably, though, Altman concludes her work by arguing that "the writer of epistolary fiction has a fundamental problem: the letter novelist (A) must make his letter writer (B) speak to an addressee (C) in order to communicate with a reader (D) who overhears"; she contends that "the very qualities that guarantee the letter work's epistolarity in the mimetic sense... work against its narrativity, making the entire concept of an 'epistolary fiction'...paradoxical" (210-11).

${ }^{4}$ Thus, she argues, "not all of letter fiction's narrative events are narrated events. In the epistolary work, acts of communication (confession, silence, persuasion, and so on) constitute important events; they are enacted rather than reported in discourse" (207).
} 
September 11, 1788 the Independent Chronicle of Boston published an anonymous letter that suggested Elizabeth Whitman's tale should be viewed as “"a good moral lecture to young ladies"'; it continues: “'She refused two as good offers of marriage as she deserved, because she aspired higher than to be a clergyman's wife; and having coquetted till past her prime, fell into criminal indulgences, proved pregnant and then eloped - pretending (where she lodged and died) to be married, and carried on the deception till her death"' (Bolton 59-60). The Massachusetts Centinel, on September 20,1788, published a letter which claimed, in part, that the writer, named only as "Curiosos," had "collected the following account of her [Whitman], for the information and improvement of your readers" (Curiosos). It stated that Whitman "was a great reader of romances, and having formed her notions of happiness from that corrupt source, became vain and coquettish, and rejected some advantageous offers of marriage in hope of realizing something more splendid; until disappointed and past her bloom, she gave way to criminal indulgence, and the consequence becoming visible, she eloped from her friends..." (Curiosos). The notion expressed here that novel reading had somehow encouraged these "notions of happiness" and thereby led to Whitman's demise underscores my point about the duality of that experience for women as it both promoted and suppressed a sense of agency. Despite these sensational accounts, what so captivated that society about Whitman's death was not how her life ended (extramarital relationships and death in childbirth were common enough), but rather how it had begun. As Davidson summarized Whitman's life, she "was the daughter of a highly respected minister...on her mother's side, she was descended from the Stanley family, which had governed Connecticut...She was also related to the [Jonathan] Edwards family, to Aaron Burr, and to the poet John Trumbull. Two of her suitors [including poet Joel Barlow] had been Yale preceptors... Hartford's highest society knew and respected her 
for her wit, her intelligence, and her charm" (Revolution and the Word 222). The newspaper letter writers also made clear their knowledge of Whitman's position in society. For example, Curiosos wrote that "... she was an unmarried lady of a reputable family in Connecticut, of the name of Whitman. In her younger days she was admired for her beauty, good sense, and other engaging qualities." The Salem Mercury, published in Salem, Massachusetts, printed an account of Whitman on July 29, 1788 that stated that "Her conversation, her writings and manners, bespoke the advantage of respectable family \& good education" (“Salem, July 29”).

The fascination in that time with Whitman's fall from such a notably socially advantageous and morally upright beginning would have contributed to the popularity of any novelistic telling of her story, but I contend that Foster's choice to use the epistolary form brought the heretofore unspoken, first-person voice of Elizabeth/Eliza to life and gave it mimetic potential for its readers in a way that no other form possibly could have done. Her pedigree as the daughter of a minister and as someone seen as virtuous enough to be courted by prominent, Yale-educated preceptors uniquely placed Elizabeth/Eliza in the exemplary position of being a woman whose familial and social status should have been solidly anchored in conventional religious beliefs that should have upheld traditional patriarchal authority. The fact that her choices often belie what should have been unimpeachable tenets of her upbringing serves to magnify the interstitial space that I argue allows for religious discourse to function as a means of both reinforcing and challenging the stereotypical position of young women as the objects of patriarchal authority in that society. In the spaces between these at times competing, elliptical narratives, The Coquette offers its female readers a unique mimetic experience, one that allows them to explore vicariously the possibility of developing their own selfhood or performing their 
own acts of agency, that is both encouraged and undermined by its underlying religious discourse.

On June 21, 1788, just one month before Elizabeth Whitman's death on July 25, 1788, the United States Constitution was formally ratified. Originally submitted in 1789, three years later, in 1791, the Bill of Rights was officially added to that Constitution, including the First Amendment, which stated, in part, that "Congress shall make no law respecting an establishment of religion, or prohibiting the free exercise thereof." While the wording of that amendment barred the federal government from establishing a national religion for the new country, it did not expressly forbid individual states from doing so. Nevertheless, most of the original colonies had in effect moved away from establishment religion prior to or during the Revolution; only Connecticut and Massachusetts emerged with multiple-establishment systems after independence. In 1818, Connecticut finally approved a new state constitution that abolished multiple establishments; Massachusetts, the originator of colonial theocracy, delayed until 1833 (Butler 267-8). Most of Elizabeth Whitman's actual life story took place in Connecticut and parts of Massachusetts; when The Coquette was published in 1797, its narrative events occurred in the same locales. Thus, the narrative world created by the experience of reading The Coquette would have been one that both consciously and unconsciously reflected the beliefs and assumptions of its actual society at that time. Many aforementioned critics have drawn on that shared cultural experience in order to locate their readings of The Coquette within postRevolutionary political discourse. I will build on those arguments by looking briefly at the ways political discourse was sometimes tied to religious discourse in late-eighteenth-century Connecticut, the state in which the vast majority of both the real-life and the fictionalized events of The Coquette took place and in which the novel would have found a considerable audience. 
According to E. Brooks Holifield, "In 1787 Jonathan Edwards, Jr. divided the clergy of Connecticut into three groups: Edwardeans, Arminians, and 'moderate' Calvinists" (127). Broadly speaking, Calvinists believed that Christ died only for the elect and that Christ's saving grace was irresistible to those elect - although some of the more moderate Calvinist thinking allowed for the possibility of human free will, but only if it were predetermined by God; the Edwardeans deviated from strict Calvinist doctrine by asserting that sinners had to have a heartfelt and immediate experience (sometimes referred to as a rebirth) of God in order to know their own salvation was at hand (and the appeal of these revivals to even the uneducated at times disturbed their more traditionally Calvinist brethren who saw enlightened, educated thinking as part of God's plan for the elect); and the Arminians rejected the Calvinist notion of particular election (the belief that God had only elected particular persons for salvation) in favor of universal election (i.e. a belief in the possibility of salvation for all people), and they further contended that grace was resistible and that the sinner could choose to resist it. ${ }^{5}$ Nevertheless, they all agreed that "reason could support a natural theology [the belief that God's revelation and existence could be known through nature] that furnished truth about the existence of God"; they believed that "the rational evidences of Christianity proved the authenticity of biblical revelation" (Holifield 128).

We can see in Reverend Boyer, one of Eliza Wharton's two competing suitors in The Coquette, a representation of this rational ideal present in the religious personage of a minister. For example, Rev. Boyer says, about himself, "I hope, and trust that I am, and ever shall be a reasonable creature; and not suffer my judgment to be misled by the operations of a blind

\footnotetext{
${ }^{5}$ However, despite some (at times complex) practical differences, these three Protestant groups did hold certain fundamental beliefs in common; according to Holifield, "Even at their most abstruse, the debates among the three groups were about the practical matter of who should be admitted to the church and how the church should propagate its message" (127).
} 
passion" (Foster 17). Later, he tells Eliza that her coquettish ways are "an aversion to the sober, rational, frugal mode of living, to which my profession leads" (Foster 83); finally, in his last communication with Eliza, he writes, in referring to his past affection for her, that "It was governed by reason, and had a nobler object in view, than mere sensual gratification" (Foster 103).

This linking of reason and rationality with the fundamental tenets of a theological ideology of faith is one that historians have often used to connect republicanism and Christianity. ${ }^{6}$ Mark A. Noll makes this connection more specific in his discussion of the famous 1783 sermon of Ezra Stiles, noted Congregationalist and president of Yale College, which he calls "one of the most dramatic expressions of the Christian-republican synthesis." He explains that 'To Stiles, 'true religion' was necessary to perfect 'our system of dominion and civil polity.' In turn, 'the diffusion of virtue' provided 'the greatest secular happiness of the people" (Noll 64). As president of Yale, which trained a huge number of the country's ministers, from 1778 to 1795 (a time period which covers the real-life events of Elizabeth Whitman and most of the time immediately preceding the publication of The Coquette), Stiles's theology and republican ideology had far-reaching influence. ${ }^{7}$ In 1794, Stiles argued that “" The common people will generally judge right, when duly informed...It is not from deficiency of abilities to judge, but from want of information, if they at any time as a body go wrong. Upon information from an abundance of enlightened characters always intermixt among them, they will ultimately always

\footnotetext{
${ }^{6}$ Noll describes this link: "Historians have long recognized the Christian republicanism of American Congregationalists and Presbyterians, the denominations that ardently favored the Revolution and that furnished the most visible spokesmen after the war to explain the religious meaning of what had transpired" (64).

${ }^{7}$ According to Christopher Grasso, "He [Stiles] agreed with James Madison that the colleges of the young Republic would lay the foundation for the future glory of America, and, by the 1780s, Yale was the largest college in the land" (264). Furthermore, Grasso states that Yale's election of Stiles to the presidency came about because "he was the only candidate that Connecticut's Armenians, Old Calvinists, and New Divinity men [a popular outgrowth of the Edwardean sect] could unite behind" (271). Noll claims that "Stiles's exuberant linkage of Christianity and republicanism marked out a path that many others followed" (64).
} 
judge right, and in the end be the faithful guardians and support and security of government"” (Grasso 273). In other words, Stiles believed that Yale's mission, to a large degree, was to provide the “"common people" with those "“enlightened characters"” who could guide and inform them of how to "“judge right." Stiles argued that "the American experiment "must receive its finishing from religion"; according to Grasso, "In Connecticut, that meant maintaining tax-supported churches...he [Stiles] considered establishment and toleration...as an enormously important safeguard in a Christian republic committed to civil liberty" (275). Stiles's vision of the "“common people" as capable of “"judg[ing] right” if given proper guidance corresponds significantly with the ideals of republican self determination that infused pre- and post-Revolutionary America.

In connecting republicanism and Christianity in Connecticut by briefly examining the ideals of Ezra Stiles and his belief in the role of Yale-educated ministers in disseminating both religious and civil post-Revolutionary ideologies, I do not mean to suggest that political discourse and religious discourse were one and the same in late-eighteenth-century New England. Instead, I wish to allow for the possibility that Connecticut's toleration of multiple denominations of Christianity modeled a system of acceptance that, in theory at least, tolerated some forms of dissention, both political and religious. Stiles, much like the state of Connecticut, did not believe in "the complete religious freedom he had called for in his younger days," according to Grasso (275). What Stiles did argue for was that “democracy's free market of ideas and opinions should still be contained by Standing Order institutions, and public opinion should be shaped by and expressed through the 'enlightened characters' Yale produced" (275). This notion of a "free market of ideas and opinions" that is still safely "contained" sounds a great deal like something Reverend Boyer says about Eliza after their first meeting: "They tell me, 
however, that she is naturally of a gay disposition. No matter for that; it is an agreeable quality, where there is discretion sufficient for its regulation. A cheerful friend, much more a cheerful wife is peculiarly necessary to a person of a studious and sedentary life" (Foster 10-11). In containing Eliza's "gay disposition" within the bounds of "discretion" and "regulation," and in specifying that "regulation" to be potentially in the form of marriage ("a cheerful wife") to "a person of a studious and sedentary life" (like himself), Rev. Boyer can be read as echoing the sentiments of Ezra Stiles's philosophy. Unlike the situation with Rev. Haly, the now-deceased minister whom Eliza's parents had chosen for her to marry, Rev. Boyer hopes to persuade Eliza to marry him rather than first persuading her parents that he would be a good match for her. ${ }^{8}$ Legally, economically, and indeed politically, women were not "“free and equal”" individuals in the new republic, nor were they equal participants in the various privileges of institutionalized religion, but religious doctrines in that time did allow salvation for women equal to that of men. Calvinists, Edwardeans, and Arminians all believed that God offered saving grace equally to women (whether those individual denominations saw that grace as part of particular or universal election). It was on that authority that Anne Hutchinson first rested her claims in 1638. By the late eighteenth century, most Edwardeans even "took a step that had remained unstated in Edward's own theology... They said that sinners became guilty of Adam's sin only by consenting to it"; some of these so-called "New Divinity" theologians became "intent on showing that both holiness and sin consisted in voluntary exercises that redefined the "heart"' ( Holifield 144). This came closer to the Arminian philosophy that taught that "the will had no power to believe unless empowered by grace, but the sinful will could resist" (Holifield 37).

\footnotetext{
${ }^{8}$ This tracks nicely with what Barnes called, "the emphasis on consent as a precondition for government" in the early years of nationhood. As aforementioned, she claims that this "transformed relations between 'free and equal' individuals, but it clouded the issue for those who could claim neither legal nor economic independence" (66).
} 
This redefining of the "heart" can certainly be read as analogous to the goals of "affectionate" marriage that Fliegelman describes. It draws on the concept of "inclination" that permeates Charlotte Temple; likewise, the notion that "consent" plays a significant role in such relationships parallels the growing popular belief in free will as a vital factor in salvation. If, then, salvation was not only conceived of as a choice of human will but as one open equally to men and women, emerging religious discourses in late-eighteenth-century New England offered at least potential acts of agency to its female adherents equal to the ones offered to its male adherents; the fact that that agency may have been "contained" by male "“enlightened characters"” did not negate its potential or its presence in the lives of female believers. I contend that we have to believe that a character like Eliza Wharton has the ability to exercise some kind of free will at some point or else there would be nothing redemptive about this story for its readers; if it offered no chance for the hope of salvation, I do not believe that its popularity would have been sustained through several generations of readers in several different political and social climates. The novel depicts, therefore, not only the political or social worlds that have been analyzed by Rust, Barnes, Davidson, and Schweitzer, but also a psychological and religious world in which the individual chooses to act and to exercise his or her free will. Since epistolarity operates as a multivalent, elliptical narration, I believe that the combination of epistolarity with religious discourse in The Coquette extends to its female readers, particularly at that time and in that place, a chance to imagine performing their own acts of agency in a way that other types of seduction narratives may not have. 


\section{III. "A melancholy event has lately extricated me from those shackles, which parental authority had imposed on my mind. Let me then enjoy that freedom..."-The Coquette}

Because the epistolary form allows readers to experience the first-person voices of each of the individual letter writers, it encourages reader identification with each of the different voices, positions, and representations present in the very dissimilar aspects of the various personages who correspond with Eliza. In employing this type of multivalent, elliptical narration, The Coquette allows for just the kind of slippage between seeming to emphasize one type of socially acceptable, moral behavior while still valorizing an imaginary opposite that Charlotte Temple does. What takes the imaginative development of female agency one step further here than in Charlotte Temple is the fact that female readers can place themselves directly in the position of voicing as Eliza does in her writing and thinking without having the matronly presence of Charlotte Temple's narrator poking in at every opportunity to reinscribe Eliza's actions within the bounds of "proper" female behavior. And while it may be true that some of the letter writers certainly do step in and perform that function, they are notably unable to do so by interrupting Eliza's own voice - they must instead wait for their own turn to "speak," as it were. That bit of distance, then, is precisely the imaginative space wherein female readers can begin to envision themselves in Eliza's place and vicariously explore their own desires to act according to what Eliza calls an "opposite disposition" which they may have been "before unconscious of possessing" (Foster 7).

This imaginative space is seen from the very beginning of The Coquette when Eliza's fiancé, a minister who was chosen for her by her parents, has just died, and she is looking forward to travelling to a friend's home and enjoying society again. As if to ensure that her sentiments not be misunderstood, Eliza confides, further on in the same paragraph, that "Both nature and education had instilled into my mind an implicit obedience to the will and desires of 
my parents" (Foster 5). Despite her joy at no longer having to conform to the "will and desires of [her] parents," Eliza attempts, in much of that first letter, to stay within what had been her habitual bounds of "proper" female behavior; she states, "The disposition of mind, which I now feel, I wish to cultivate. Calm, placid, and serene; thoughtful of my duty, and benevolent to all around me, I wish for no other connection than that of friendship" (Foster 6). However, she quickly reverses those sentiments when she writes again to her friend Lucy in "Letter II": "Time, which effaces every occasional impression, I find gradually dispelling the pleasing pensiveness, which the melancholy event [her fiancé's death], the subject of my last [letter], had diffused over my mind. Naturally cheerful, volatile, and unreflecting, the opposite disposition, I have found to contain sources of enjoyment, which I was before unconscious of possessing" (Foster 7). So while at first "nature" had "instilled into [her] mind an implicit obedience to the will and desires of [her] parents," she now finds herself "naturally cheerful, volatile, and unreflecting, the opposite disposition." In other words, she now realizes that her own desires and "natural" disposition may not necessarily be in keeping with society's or her family's expectations for acceptable female behavior-being "calm, placid, and serene; thoughtful of my duty, and benevolent to all around me" has been dispelled in favor of "the opposite disposition." The disjunction between Eliza's “disposition” and her family's expectations is further illuminated when she writes to her friend Lucy no less than eight times without readers ever seeing the direct reply of her caring and more conservative friend. Instead, readers only know that Lucy has written to Eliza by reading Eliza's own references to those letters; the act of Eliza's letter writing thus becomes what Altman has called the "narrated" event. For example, in “Letter II,” Eliza writes to Lucy, 
I have received your letter; your moral lecture rather; and be assured, my dear, your monitorial lessons and advice shall be attended to. I believe I shall never again resume those airs, which you term coquettish [emphasis Foster's], but which I think deserve a softer appellation; as they proceed from an innocent heart, and are the effusions of a youthful, and cheerful mind. We are all envited to spend the day, to morrow, at Col. Farrington's, who has an elegant seat in this neighbourhood. Both he and his Lady are strangers to me; but the friends, by whom I am introduced, will procure me a welcome reception. (Foster 7)

So, Eliza's own voice is able to acknowledge her past "coquettish" behavior and summarily dismiss it, along with Lucy's letter, without readers ever seeing the "narrative" events or even reading Lucy's direct words to know what specific behavior she was referencing. Likewise, immediately following those sentences, Eliza writes that she will be spending the next day in high society, and not with intimate friends but with "strangers"; this gay behavior would have been considered unbecoming in one who was supposed to be in mourning. On the surface, then, these comments seem to reinforce the didactic nature of conventional seduction narratives: Eliza is a carefree girl seeking her aforementioned "pleasure" despite the very recent deaths of her father and her fiancé — in other words, she is a coquette, thoughtless and shallow—and young, female readers must be cautious about identifying with her. In a traditionally narrated novel, they would be encouraged to identify with the more reasonable, conservative voice of Lucy or of a narrator and thereby judge Eliza's actions, as shown in the narrative, accordingly. But in this epistolary telling there is no matronly narrator and no direct depiction of narrative events, and Lucy's voice is also noticeably silent when compared to the number of "published" letters she is afforded versus those of Eliza. The form of the text itself belies the expected moralizing and 
didacticism of most traditional seduction novels. Indeed, in the first half of the novel, when Eliza makes the choices that will eventually lead to her fall from grace, readers see fourteen of her long letters to Lucy but only four of Lucy's much more brief replies to Eliza.

In fact, before any of Lucy's letters to Eliza are even shown to the reader at all, "Letter IV" of the novel, from Reverend Boyer to his confidant, Thomas Selby, is presented. After meeting Eliza only once, Rev. Boyer forms an attachment to her; such a hastily-formed attachment may in fact comment on the contemporary social perception of certain religious clerics and their followers as, at times, overly emotional, but it nevertheless also reinforces the depiction of Eliza as a virtuous woman who could certainly attract a man of that class. Boyer exemplifies a state of heartfelt religious faith as it seeks to be reflected in the object of its desire, as he writes to his friend upon first meeting Eliza: "You ask me, my friend, whether I am in pursuit of truth or a lady? I answer, both. I hope and trust they are united; and really expect to find truth and the virtues and graces besides in a fair form" (Foster 10).

That Eliza chooses not to honor Rev. Boyer's request for an intimate connection immediately but still encourages his affections speaks to the fact that she hopes to enjoy her freedom for a bit longer while still understanding the reality of her situation (i.e. her economic and social need to marry eventually). Very early in her relationship with Rev. Boyer, Eliza writes a letter to Lucy in which she relates telling her cousin, Mrs. Richman (who is attempting to encourage Eliza to accept Rev. Boyer's advances), “I hope my friends will never again interpose in my concerns of that nature...I am young, gay, volatile. A melancholy event has lately extricated me from those shackles, which parental authority had imposed on my mind. Let me then enjoy that freedom which I so highly prize. Let me have opportunity, unbiased by opinion, to gratify my natural disposition in a participation of those pleasures which youth and 
innocence afford." Mrs. Richman responds to these sentiments by cautioning Eliza: "Of such pleasures, no one, my dear, would wish to deprive you. But beware, Eliza!- Though strowed with flowers, when contemplated by your lively imagination, it is, after all, a slippery, thorny path. The round of fashionable dissipation is dangerous. A phantom is often pursued, which leaves its deluded votary the real form of wretchedness" (Foster 13).

After this warning, Mrs. Richman leaves Eliza to her own contemplations and bids her "good night"; at this moment, the epistolary form is able to once again blur the lines between what Eliza may be thinking in the moment—what she writes as she continues her correspondence with Lucy — and what the reader may be able to experience vicariously through the type of mimesis fostered by this epistolarity. Eliza's next words invite the female reader to imagine asserting her own freedom and to identify with Eliza in defying the safe path to virtuous, affectional marriage offered by Rev. Boyer; yet, they still allow for the possibility that she may choose that path eventually: "Something seemingly prophetic in her [Mrs. Richman's] looks and expressions, cast a momentary gloom upon my mind! But I despise those contracted ideas which confine virtue to a cell. I have no notion of becoming a recluse" (Foster 13). Eliza simply wishes for the freedom to act without the "shackles... of parental authority" or other such similarly limiting forces which would "confine virtue to a cell"; in stating that she has "no notion of becoming a recluse," what Eliza is actually doing is asserting her desire to test her "virtue" on her own terms, outside of the "cell" of either "parental authority" or marriage. She does not believe that her desire for that freedom will lead down the "slippery, thorny path" Mrs. Richman describes, and Rev. Boyer's initial description of her supports that belief from another perspective. Rev. Boyer describes Eliza to his friend, Thomas Selby: 
She was formerly addressed by the late Mr. Haly of Boston. He was not, it seems, the man of her choice; but her parents were extremely partial to him, and wished the connection to take place. She, like a dutiful child, sacrificed her own inclination to their pleasure, so far as to acquiesce in his visits. This she more easily accomplished, as his health, which declined from their first acquaintance, led her to suppose, as the event has proved, that he would not live to enter into any lasting engagements. Her father, who died some months before him, invited him to reside at his house... She attended him during his last illness, with all the care and assiduity of a nurse; and with all the sympathising tenderness of a sister. (Foster 11)

Several significant developments in the progression of the early-national concept of marriage and the role of religious discourse are thus privileged within this brief, early description of Eliza (made by a minister who has just met her rather than by one of her closest friends or family members): first, the forthright assumption that a woman's "choice" or "inclination" may play a productive role in a potential marriage relationship, rather than only playing one in cases of seduction (wherein "inclination" is to be resisted); second, the valorizing of behavior that on its face appears to reinforce parental authority but in reality only pays it lip service (as when Eliza agrees to marry a man her parents favor only because she believes him to be mortally ill); third, the clear implication by Rev. Boyer that in depicting a "dutiful" daughter as a "child" he allows himself to assume that a grown woman (such as Eliza now is) may no longer be bound by such duties and may in fact seek a "man of her choice"; and, fourth, the unstated assumption that, could he sway Eliza's "inclination" toward himself, she would accept a marriage proposal with much more pleasure and, indeed, more freedom than she had previously. Notably, it was just 
before this passage that Rev. Boyer wrote the aforementioned words, "They tell me, however, that she is naturally of a gay disposition. No matter for that; it is an agreeable quality, where there is discretion sufficient for its regulation. A cheerful friend, much more a cheerful wife is peculiarly necessary to a person of a studious and sedentary life" (Foster 10-11). The fact that such words come from the pen of a minister, a man who is depicted throughout the novel as, as Lucy writes at one point, an "excellent partner," a "worthy man," and one whose "taste is undebauched, his manners not vitiated, his morals uncorrupted" (Foster 27), only lends them more weight.

Rev. Boyer stands as the voice and representation of virtuous religious discourse, and yet he himself seems to subscribe to the belief that Eliza has the right to choose her own marriage partner, presuming of course that she must consent eventually to submit herself to "discretion" and "regulation"; this clearly reflects Ezra Stiles's philosophy, Fliegelman's idea of “affectional and voluntaristic marriage" (129), and what Barnes described as a "republican vision of voluntary obligation" (66). Now that Eliza's father has died, she may make a different choice. If we read that ability to choose differently as only parallel to the political, legal, and economic discourses of that time, we are hemmed in by the inevitable limitations surrounding women already noted by Davidson, Rust, Barnes, Schweitzer, and many other critics because such discourses identify men as the sole negotiators in those situations. Early-national religious discourse, on the other hand, while also patriarchal, at least offered women a position from which they could begin to assert a kind of agency and a measure of self expression. Such discourse cannot be read as depicting any sort of utopian ideal for women's rights, but it does at least provide an opening through which a start at actual self formation can be imagined. 


\section{IV. "Should it ever be my fate to wear the hymenial chain, may I be thus united!"-The Coquette}

As discussed earlier, Barnes and Schweitzer both question the degree to which women may truly participate in a "voluntary" system, being in actuality neither "free" nor "equal" to the men they may marry, and many of the letter writers in The Coquette seem all too aware of that reality. In her very first "published" letter to Eliza, Lucy tells her quite frankly that marrying a clergyman may be as high on the social ladder as Eliza can hope to climb: "His situation in life is, perhaps, as elevated as you have a right to claim" (Foster 27). Eliza acknowledges this in the first line of her response to Lucy: "I have received, and read again and again, your friendly epistle. My reason and judgment entirely coincide with your opinion; but my fancy claims some share in the decision: and I cannot yet tell which will preponderate" (Foster 28). So, while Davidson contends that Eliza "naively" hopes to exercise a freedom that she does not in fact possess, I think that Eliza is actually acutely aware of the limitations placed on her freedom by her political, legal, and economic status. Therefore, I believe that she makes a conscious choice to extend the small window of time in which she can continue to participate in the one type of freedom still open to her: the freedom of choice. Much like the sinner's ability to choose to accept or reject Christ's saving grace, Eliza can choose when or if she might accept the salvation of a "good" marriage to Rev. Boyer.

The idea that her desire to make her own choice is a conscious one is also seen when Eliza writes to Lucy, "The heart of your friend is again besieged. Whether it will surrender to the assailants or not, I am unable at present to determine. Sometimes I think of becoming a predestinarian, and submitting implicitly to fate, without any exercise of free will; but, as mine seems to be a wayward one, I would counteract the operations of it, if possible" (Foster 24). This passage typifies the debate between competing religious ideologies in the early nation that 
questioned the extent to which humans could exert their free will in choosing to resist either sin or salvation. Worrying that her heart may be "wayward," that it may blindly proceed with no direction from her, Eliza makes the choice at least to try to "counteract the operations of it, if possible" rather than "becoming a predestinarian, and submitting implicitly to fate." Also in keeping with early-national religious discourses that valued reason and rationality, Eliza demonstrates her keen awareness of and her rational response to the affections of Rev. Boyer in several places throughout the novel. Most notably, she writes to Lucy, after once again telling her cousin, Mrs. Richman, that she will not commit to marrying Rev. Boyer yet: 'Mr. Boyer's person, and character are agreeable. I really esteem the man. My reason and judgment, as I have observed before, declare for a connection with him, as a state of tranquility and rational happiness. But the idea of relinquishing those delightful amusements and flattering attentions, which wealth and equipage bestow, is painful. Why were not the virtues of the one, and graces and affluence of the other combined?" (Foster 53). Herein, Eliza clarifies the "wayward"-ness of her heart; she knows in her "rational" mind that her own "happiness" is dependent on making an attachment to a man with "virtues," but, like the wayward sinner who perhaps too much revels in the hedonistic joys of sin and so has not yet chosen to accept Christ's saving grace, Eliza is not yet ready to give up the "graces and affluence" she has experienced while maintaining her single status. The particular "sin" that she is not willing to give up is embodied in her other chief suitor, Major Sanford. (Sanford, a handsome and charming man, lives a life of pleasurable dissipation unaccompanied by most virtues; he attends balls and parties, gambles away his inheritance, and determines to marry for money — which Eliza does not have — in order to relieve his straitened circumstances.) 
Consciously delaying her actual moment of either consciously choosing virtuous marriage or submitting to fate and following the "wayward" actions of her heart allows Eliza to experience a small portion of the freedom for which she yearned. Her active voicing of that desire for freedom actually serves to open a space wherein female readers can vicariously begin to imagine exercising the freedom to which they may not have been privy in reality. Eliza is quite adept at navigating the narrow gap between her own desires (for "pleasure" and "freedom") and the reality of her "situation in life" as an unmarried, dependent woman and thereby prolonging the time during which she may remain unattached and during which she may experience her own agency. Quite directly, she tells Rev. Boyer, "You must either quit the subject [of marriage], or leave me to the exercise of my free will, which perhaps may coincide with your present wishes." Eliza is deliberately admitting that she "perhaps may" marry Rev. Boyer yet directly voicing her desire to "exercise...[her] free will." And Rev. Boyer, the symbol of righteous moral and religious behavior, replies, "Madam...far is the wish from me to restrain your person or mind. In your breast I will repose my cause" (Foster 29). So, rather than insisting on an immediate answer, Rev. Boyer respects Eliza's free will as perhaps only a devotee of the theology of that time could. In placing his "cause" in Eliza's "breast" (i.e. close to her heart), Boyer hopes for Eliza to experience that heartfelt, emotional conversion (indeed, to come to love him) necessary in religious revivals and thereby underscores the importance of emotion, along with rational judgment, in certain religious experiences. For young, female readers, however, his willingness to wait for Eliza's "fancy" to catch up with her "reason and judgment" serves only to draw out the time wherein they can vicariously imagine exploring their own fancies and freedoms. Rev. Boyer's position as the representative of that acceptable religious discourse validates this vicarious experience as one that would have been encouraged 
by religious institutions of the time as they promoted freely-experienced, heartfelt conversions for their members.

The possibility of reason and judgment leading to such an emotional conversion is affirmed later in the text when Eliza spends three solitary days at the Richman's house, during which time Rev. Boyer visits her without any outside distractions from Major Sanford or any of her other suitors. Eliza writes to Lucy:

I believe I must begin to assume airs of gravity; and they will not be quite so foreign to my feelings now, as at some other time. You shall know the reason. I have been associated for three days, with sentiment and sobriety, in the person of Mr. Boyer. I don't know but this man will seduce me into matrimony. He is very eloquent upon the subject; and his manners are so solemn, that I am strongly tempted, yet I dare not to laugh. Really, Lucy, there is something extremely engaging and soothing too, in virtuous and refined conversation. It is a source of enjoyment which cannot be realised by the dissolute and unreflecting. (Foster 656)

This letter reflects Eliza's potential to enjoy both "sentiment and sobriety" alongside her ability to be engaged and soothed by "virtuous and refined conversation." As such, it directly voices her knowledge that "matrimony" can be a source of enjoyment, one that she may be "tempted" by, and one that she knows she will have to choose to enter into eventually. She tells Rev. Boyer of this likelihood, but cautions that he must "let me take my own time for the consummation" (Foster 66). In placing the word, "tempted" as she does in the sentence, it can be used to apply both to "matrimony" and to her inducement "to laugh." So, once again, even though she seems to come closer to acquiescing, Eliza makes it clear, first to herself and her readers, and then 
directly to Rev. Boyer himself, that she will extend the moment of her choice, the only one she may ever have, for as long as possible.

After the previous exchange between Eliza and Rev. Boyer, Eliza's cousin, Mrs. Richman, follows her up to her room wherein (as Eliza later writes to Lucy), "I related to her the conversation, and the encouragement which I had given to Mr. Boyer" [i.e. that she had indicated that she might marry him at some point in the future]. Due to this "encouragement," Mrs. Richman insists that Eliza "should own [her]self somewhat engaged to him." Eliza's voiced reaction to this suggestion underscores the importance of even a temporary or illusory freedom for her: "This, I told her I should never do to any man, before the indissoluble knot was tied. That, said I, will be time enough to resign my freedom.” Mrs. Richman informs her that she "had wrong ideas of freedom, and matrimony; but she hoped that Mr. Boyer would happily rectify them" (Foster 30). Likewise, her friend Lucy attempts to reign in Eliza's notions of freedom when she tells her to, "Act then with that modest freedom, that dignified unreserve which bespeaks conscious rectitude and sincerity of heart" (Foster 27). Lucy attempts to qualify Eliza's "ideas of freedom," rather than suggesting that they are "wrong," and contends that they should be more "modest" in order to coincide with "conscious rectitude and sincerity of heart." Lest readers believe that Eliza's "wrong ideas of freedom" are rooted in the person of an uneducated, unthinking, foolish, young girl, several letters from several different writers make statements to the contrary. On more than one occasion, Rev. Boyer, Lucy, and even Eliza's eventual seducer, Major Sanford, refer to Eliza's "accomplished mind." One of the strongest examples, though, is when Mr. Selby observes in one of his notes to Rev. Boyer that "there is an air of gaiety in her appearance and deportment which favors a little of coquetry. I am persuaded, however, that she has too much good sense to practice its arts" (Foster 43). Later, in the same 
letter, he continues his description of Eliza: "Indeed, she discovers a fund of useful knowledge, and extensive reading, which render her peculiarly entertaining; while the brilliancy of her wit, the fluency of her language, the vivacity and ease of her manners, are inexpressibly engaging" (Foster 46). In addition, in one extraordinary letter in the novel, Eliza and Mrs. Richman participate in a conversation about politics, in mixed company: "I [Mr. Selby] now joined in the general topic of conversation, which was politics. Mrs. Richman and Miss Wharton judiciously, yet modestly, bore a part." When one of the young ladies in the group protested that "she never meddled with politics,” Mrs. Richman spoke up to defend herself and Eliza:

We think ourselves interested in the welfare and prosperity of our country; and, consequently, claim the right of inquiring into those affairs, which may conduce to, or interfere with the common weal. We shall not be called to the senate or the field to assert its privileges, and defend its rights, but we shall feel for the honor and safety of our friends and connections, who are thus employed. If the community flourish and enjoy health and freedom, shall we not share in the happy effects? if it be oppressed and disturbed, shall we not endure our proportion of the evil? Why then should the love of our country be a masculine passion only? Why should government, which involves the peace and order of the society, of which we are a part, be wholly excluded from our observation? (Foster 44)

Mr. Selby relates the remarkable response to this little speech: "The gentlemen applauded Mrs. Richman's sentiments as truly Roman; and what was more, they said, truly republican" (Foster 44). While we can by no means hope to know if Foster included this moment as a reflection of her own views on the place of educated women in politics or if such a scene may have been one that she could have encountered in her daily life in Connecticut, we can at the very least assume 
that it was disseminated to the readers of The Coquette as a viable possibility within the multivalent world of this novel and the experience of those reading it. Mr. Selby finds it worthy of narrating in detail, which suggests that it has importance to him as well as to his potential reader of that letter, Rev. Boyer. If these two men, who are both depicted as model citizens, find it to be acceptable and even admirable for Eliza and Mrs. Richman to express these "republican" sentiments, then they can be read as endorsing this type of "truly Roman" thinking and behavior in any similarly-educated women. It implies that these women see themselves as knowledgeable participants in the new nation; they "claim the right" of, at the very least, making an "observation" on that "government...of which [they] are a part."

That it is Mrs. Richman who voices those "republican" sentiments has special weight as well. Very early in the novel, in "Letter VI," Eliza writes to Lucy with a detailed depiction of the Richman's marriage:

...they were better pleased with each other than with me; and soon rising, walked into the garden, and left me to amuse myself alone. My eyes followed them through the window. Happy pair, said I. Should it ever be my fate to wear the hymenial chain, may I be thus united! The purest and most ardent affection, the greatest consonance of taste and disposition, and the most congenial virtue and wishes distinguish this lovely couple. Health and wealth, with every attendant blessing preside over their favored dwelling, and shed their benign influence without alloy. (Foster 14)

From this point on, Eliza idealizes the Richman's marriage in most of her references to it. Indeed, we can even imagine that the fictional name "Richman" may refer to the representative "riches" found therein. On the next page of this letter Eliza writes that "Mrs. Richman's present 
circumstances render her fond of retirement," which would have signaled to readers at that time that she was pregnant (Foster 15). Later in the novel, Eliza writes to Mrs. Richman and tells her, "I am anxious to hear of a wished for event and of your safety" (Foster 69). This statement shows that Mrs. Richman will soon give birth while also reminding readers of one very real, lifethreatening consequence of marriage: childbirth. These potentially mortal consequences for the wife and mother are juxtaposed against the description, in the letter that immediately follows that one, of the husband and father's sentiments upon the birth of his child: "...yesterday, that lovely and beloved woman presented me with a daughter. This event awakens new sensations in my mind; and calls to exercise a kind of affection which had before lain dormant. I feel already the tenderness of a parent; while imagination fondly traces the mother's likeness in the infant form" (Foster 69). This brief, barely half-a-page epistle is the only letter directly written by a husband or a father in the entire novel, which illustrates this text's privileging of those voices that did not stand in the traditional positions of patriarchal authority in that society. That the one instance of such a voice should appear to dote upon and worship his wife and daughter (not son) is also noteworthy.

Were The Coquette a novel that could be read as simply reifying or reinforcing the stereotypical republican norms of patriarchal power in the new nation, this would be the end of the part of the narrative involving the Richman's marriage or the birth of their child. However, it is not that simple; their marriage may not be meant to be a cheerful mirror of idealistic republican marriage values in the early nation. If it were, I believe that their child would have: (a) been male, and/or (b) lived to exemplify, eventually, a virtuous and fruitful adulthood. Instead, the child is a female who dies at a very young age. On the surface, this death appears arbitrary and wholly unnecessary to the narrative and even seems to contradict the didacticism of 
the seduction to which Eliza ultimately falls prey. If young, female readers are meant to seek out a model marriage like the Richman's, which looks to be the very essence of an "'affectional and voluntaristic"" relationship, then why would the fruit of that model union die at such a young age? If The Coquette were only a kind of didactic morality tale, then the sole person who should have been punished should have been the one sinning, not the ones who had already chosen the salvation of virtuous marriage.

The timing of the Richman's daughter's death may illuminate some of the seeming contradictions inherent in it as "little Harriot" dies almost immediately after the moment in which I believe Eliza finally and completely acquiesces to Major Sanford's seduction of her. In order to understand this, we must first look at the outcome of Eliza's choice to prolong her moment of "free will" for as long as possible. The turning point of the novel comes almost exactly halfway through it, in "Letter XLI," which is also the longest letter in The Coquette. In it, Eliza, who has gone to her childhood home to visit her mother, writes to Lucy and describes what life is like in her hometown now that Major Sanford has moved nearby:

Indeed, the customs and amusements of this place are materially altered, since the residence of Major Sanford among us. The dull, old fashioned sobriety which formerly prevailed, is nearly banished; and cheerfulness, vivacity, and enjoyment are substituted in its stead. Pleasure is now diffused through all ranks of the people, especially the rich...though some of our old dons think him rather licentious; yet, for ought I can see, he is as strict an observer of decorum, as the best of them. True, he seldom goes to church; but what of that? The Deity is not confined to temples made with hands. He may worship him as devoutly elsewhere, if he chuses; and who has a right to say he does not? (Foster 85-6) 
Eliza's view of "pleasure" as it is "diffused" by Sanford is fraught with language that readers would have generally associated with the dissipations of sin: it is enjoyed by the "rich," wise “old dons" think him "licentious," and "he seldom goes to church." In flirting with him, Eliza acts as if she must have one, last, hedonistic brush with sin before she does what she spoke of very early in the novel and makes the choice to "confine [her] virtue to a cell" and become "a recluse" (Foster 13). Following her description of Sanford, she writes to Lucy the words she has told her mother, who has expressed concern that Eliza was "associating so freely with him [Sanford]": "If I am to become a recluse, let me, at least, enjoy those amusements which are suited to my taste, a short time first" (Foster 86), which clearly implies her actual intention to choose to become a "recluse" eventually. Soon after, the letter continues, Eliza directly tells Sanford that she intends to marry Rev. Boyer, unless Sanford will do the honorable thing: While he [Sanford] would disconnect me from another, he mysteriously conceals his own intentions and views...I plainly told him that his conduct was unaccountable; that if his professions and designs were honorable he could not neglect to mention them to my mamma; that I should no longer consent to carry on a clandestine intercourse with him; that I hourly expected Mr. Boyer, whom I esteemed, and who was the favorite of my friends; and that unless he acted openly in this affair before his arrival, I should give my hand to him. (Foster 87) This passage demonstrates that Eliza is aware that Sanford's "designs" may not be "honorable"; she knows that if they were, then he would act "openly in this affair." After this, Eliza again directly voices her knowledge of her own state of mind and of her own ability to be tempted by sin while still being aware that she is capable of resisting it; she writes to Lucy: "Now, my dear friend, I want your advice more than ever. I am inadvertently embarrassed by this man 
[Sanford]; and how to extricate myself, I know not. I am sensible that the power is in my hands; but the disposition (shall I confess it) is wanting!" (Foster 87-88). Eliza knows that she has the "power" to "extricate" herself from Sanford's seductive grasp, but her "disposition" is still tempted by $\sin$.

Despite Eliza's apparent unwillingness to turn away from sin until she absolutely mustuntil she is on the verge of losing her free ability to choose-Eliza's letter (to which she continues to add over the course of several days) voices the genuine state of her heart when she sees Rev. Boyer again after having been away from him while she stayed at her mother's: “On my return [from riding with Sanford] I found Mr. Boyer waiting to receive me. My heart beat an involuntary welcome. I received him very cordially, though with a kind of pleasure mixed with apprehension" (Foster 88). In the absence of the virtuous influence represented by Rev. Boyer (a model for one of Stiles's “enlightened characters"), Eliza may have been tempted to sin more easily than she would have been had he been present, but her "heart," significantly, "beat[s] an involuntary welcome" and she is able to experience a kind of "pleasure mixed with apprehension" upon seeing him. This implies, to readers well-versed in religious doctrine, that Eliza's "heart" is on the verge of making the true conversion that marriage to Rev. Boyer has come to represent. Her "apprehension," I contend, is only due to the fact that she is still prolonging her enjoyment of the expansive moment of exercising her free will and her freedom; she does not wish it to end (as it must for any woman at that time and in that society-as so many critics have already shown). Indeed, Eliza insists on delaying even longer by "begg[ing] absolution" when Rev. Boyer asks if she has made her decision as to "when [her] hand should be given" (Foster 88). Rev. Boyer finally expresses frustration when Eliza "sought still to evade, and put off the important decision": "he grew warm; and affirmed that I treated him 
ungenerously, and made needless delays...He would leave me, he said, this evening and call to morrow to know the result of my determination" (Foster 88-9).

The next day, as Eliza naps, her mother receives Major Sanford, but "she thought it unnecessary to call [her]." This minor deception on her mother's part leads to Eliza's last voicing of her independent desire for freedom, which stands in stark contrast to her initial acquiescence to the "shackles" of "parental authority" depicted in the beginning of the novel. She writes to Lucy that she told her mother that "I knew the motives by which she was actuated, and was vexed at her evasions. I told her plainly, that she would never carry her point in this way; that I thought myself capable of conducting my own affairs; and wished her not to interfere, except by her advice, which I should always listen to, and comply with when I could possibly make it consistent with my inclination and interest" (Foster 89). Eliza's "natural" dispositionnamely her defiance and resistance to any hindering of her "free will" — is aggravated by her mother's "interfere[nce]"; immediately following this scene, she receives a note from Major Sanford and agrees to meet with him one last time.

While this meeting with Sanford is not the one in which he actually seduces her, it is the one that makes that seduction nearly inevitable. The tragedy of this novel is not that Eliza is seduced; the tragedy is that she cannot resist the urge to forestall the end of her freedom, which would cease at the moment she declared her intention to marry Rev. Boyer directly to him. For the sinner cannot know the day nor the hour when the Lord will come; if he or she remains unrepentant in hopes of delaying the time when sin must be relinquished, he or she risks eternal damnation. ${ }^{9}$ Eliza's decision to meet with Sanford one more time before declaring her intentions

\footnotetext{
${ }^{9}$ The Bible says in Matthew 24:36-44, "But about that day or hour no one knows, not even the angels in heaven, nor the Son, but only the Father... Therefore keep watch, because you do not know on what day your Lord will come. But understand this: If the owner of the house had known at what time of night the thief was coming, he would have
} 
openly to Rev. Boyer leads to her symbolic damnation and nearly inevitable seduction. She even writes to Lucy, immediately prior to this meeting, that "After mature consideration; after revolving and re-revolving every circumstance on both sides of the question, I have nearly determined, in compliance with the advice of my friends, and the dictates of my own judgment, to give Mr. Boyer the preference, and with him to tread the future round of life. As to the despair of Major Sanford, it does not much alarm me. Such violent passions are seldom so deeply rooted, as to produce lasting effects" (Foster 91).

So, Eliza consciously knows, as her "own judgment" "dictates," that a life with Rev. Boyer is the best choice and that Major Sanford's "violent passions" are not to be relied upon. But much like the sinner who must have one last wild night of sin before forgoing it completely, Eliza agrees to a clandestine meeting with Sanford, alone and unchaperoned, in a secluded arbor (not out in public or in her mother's house). Rev. Boyer arrives at Eliza's mother's house and, being told she is out walking in the garden-Eliza's mother does not know that she has agreed to meet Sanford - he goes looking for her. Upon finding her thus occupied, Eliza writes to Lucy, Rev. Boyer "spoke not a word, but casting a look of indignant accusation at me, a glance which penetrated my very soul, turned on his heel, and walked hastily back to the house" (Foster 92). Rev. Boyer's "glance" is almost literally like the eye of God in that he can see into her "very soul." He later "declared his determination to leave me for ever, as unworthy of his regard, and incapable of love, gratitude, or honor!- There was too much reason in support of his accusations for me to gainsay them..." (Foster 92-3). Finally, Eliza writes that "When I saw that he was gone; that he had actually forsaken me, I fainted" (Foster 93).

kept watch and would not have let his house be broken into. So you also must be ready, because the Son of Man will come at an hour when you do not expect him." 
When Eliza faints, she quite literally loses her conscious ability to reason. This loss of reason is one from which she cannot recover now that she has lost forever the possibility of salvation represented by marriage to Rev. Boyer. Indeed, she spends the remainder of the novel in a state of depressed solitude; though she may, presumably, have still been able to attend balls and participate in society, she now seems incapable of acting on her own behalf in any way. Mrs. Richman writes to her and expresses concern with this: "The detail which my sister gave me of your separation from Mr. Boyer was painful; as I had long contemplated a happy union between you. But still more disagreeable sensations possessed my breast, when told that you had suffered your lively spirits to be depressed, and resigned yourself to solitude and dejection!” (Foster 96). Lucy, too, echoes these concerns when she writes to Eliza: "Where, O Eliza Wharton! Where is that fund of sense, and sentiment which once animated your engaging form? Where that strength of mind, that independence of soul, that alacrity and sprightliness of deportment, which formerly raised you superior to every adverse occurrence? Why have you resigned these valuable endowments, and suffered yourself to become the sport of contending passions?" (Foster 107).

Now that her symbolic salvation has been relinquished, Eliza seems to be incapable of rationally resisting sin as well. She continues to meet with Major Sanford, although only when he initiates it - in fact, never once in The Coquette does she write a letter directly to Sanford, which illustrates the fact that her voiced sin is the more important one rather than the unspoken one that she will eventually commit with him_-and she seems unable to say no to him or to stay firm in her resolve to say no to him. Indeed, only the fact that another friend, Miss Julia Granby, has come to stay at Eliza's mother's house and literally shares Eliza's bed seems to keep her from acquiescing to the ending act of Sanford's seduction. When Julia, after some months, must 
eventually leave, she writes to Lucy, "I regret leaving Eliza! I tremble at her danger! She has not the resolution to resist temptation, which she once possessed. Her mind is surprisingly weakened! She appears sensible of this; yet adds to it by yielding to her own imbecility" (Foster 132). Significantly, by this point in the novel, Eliza's own letters have become less and less frequent, replaced instead with the words of friends. Her loss of the ability to resist sin coincides with her loss of voice. Julia tells Lucy: "You will receive a letter from her with this; though I had much difficulty to persuade her to write. She has unfortunately become very averse to this, her once favorite amusement" (Foster 132). The enclosed letter is not reprinted for the reader of The Coquette, though, which only serves to highlight Eliza's textual voicelessness.

It is at this moment, when Julia leaves and Eliza's last physical constraint on enacting the sin that she has already fallen to in her soul is removed, that I believe Eliza is finally seduced by Sanford. While Julia is gone, Eliza does write to her, but only to tell her of the death of the Richman's baby: "I have just written a long consolatory letter to Mrs. Richman. She has buried her babe; her little Harriot, of whom she was doatingly fond." Just after this sentence she voices the following lines: "It was a custom with some of the ancients, we are told, to weep at the birth of their children. Often should we be impelled to a compliance with this custom, could we foresee the future incidents of their lives. I think, at least, that the uncertainty of their conduct and condition in more advanced age, may reconcile us to their removal to a happier state, before they are capable of tasting the bitterness of woe" (Foster 134). She even includes a brief poem that shares the same message:

“Happy the babe, who, priviledg'd by fate,

To shorter labors, and a lighter weight, Receiv'd but yesterday the gift of breath; 
Order'd to morrow, to return to death."

Thus, the Richman's daughter's death can be read as occurring at this moment for two reasons: first, most readers would have been aware of the conventions of seduction novels and so would have realized that Eliza had in fact fallen to the actual act of seduction once the constraining presence of Julia Granby in her bed was removed. So, Eliza's seduction, narratively speaking, kills the innocent babe who otherwise would have faced the same struggle with free will that Eliza did. It is as if Eliza's one bad act has polluted the innocence of this (and perhaps all) babe; her act admits the possibility that Harriot, too, will make choices like the ones Eliza did, and so she must die to avoid them.

The second reason for Harriot's death is related to that notion but is also more complicated. Rather than reading Harriot's death as a punishment for Eliza's act of sin, if readers did actually believe that the Richmans' marriage was an idealistic model, then, because Harriot is still innocent and has not fallen, a benevolent God could be viewed as rewarding them with her death as a kind of salvation from the eventual circumstances that any woman in that society would have faced. She is saved preemptively, while she is still innocent, because she is " "priviledg'd by fate"" in being born to model parents. But, as far as readers know, Eliza herself was " "priviledg'd by fate" when she was born to her parents who also seemed, by all accounts, to be model spouses and parents. However, they may not necessarily have been models of Christian or republican values in the new nation; after all, they did not guide Eliza into making the proper choice herself, as a "voluntary obligation," but instead imposed the "shackles" of "parental authority" to force her to submit to marrying Rev. Haly. Only the death of Eliza's father (and, of course, of Rev. Haly, who is guilty of consenting to this forced marriage) 
alleviates the grip of those "shackles."

\section{Conclusions: "Should it please God to spare and restore me to health..."-The Coquette}

Eliza's last letters of the novel are written to her mother and to her friend, Julia Granby. Prior to these, her final words, Julia takes over the relating of Eliza's voice when she writes to Lucy about the now "ruined, lost Eliza" (Foster 141). Because Eliza has relinquished her ability to act on her own behalf, as signified by her voicing of her own desires, she writes fewer and fewer letters in the last half of the novel until only other people are left to narrate her actual tale. Her voicing, therefore, becomes indirect, usually through the pen of Julia. This reverses the original form of the letters in The Coquette in which Eliza penned the voices of others and of herself. In "Letter LXVII," Julia recounts to Lucy a scene in which Eliza begs her mother's forgiveness. Her mother, who still does not realize that Eliza is pregnant, gives it to her unconditionally:

She then approached her mamma, fell upon her knees before her, and clasping her hand, said, in broken accents, Oh madam! can you forgive a wretch, who has forfeited your love, your kindness, and your compassion? Surely, Eliza, said she, you are not that being! No, it is impossible! But however great your transgression, be assured of my forgiveness, my compassion, and my continued love! Saying this, she threw her arms about her daughter's neck, and affectionately kissed her. Eliza struggled from her embrace, and looking at her with wild despair, exclaimed, this is too much! Oh, this unmerited goodness is more than I can bear! She then rushed precipitately out of the room, and left us overwhelmed in sympathy and astonishment! When Mrs. Wharton had recovered 
herself a little, she observed that Eliza's brain was evidently disordered. Nothing else, continued she, could impel her to act in this extraordinary manner. (Foster 149)

Eliza wants forgiveness, but her mother's forgiveness has little effect on her because it is God's saving grace that she actually seeks (and her mother, as a woman, would not have been seen at that time as a potential representative of that grace). However, Eliza's rational ability to use her reason and judgment to seek salvation, as exemplified by her "brain," is gone. In her final words of the novel, Eliza writes to Julia from the inn where she has clandestinely fled to await the birth of her child. Therein, she vocally submits herself to God for the first time in the entire novel when she writes, "Should it please God to spare and restore me to health, I shall return, and endeavor, by a life of penitence and rectitude, to expiate my past offences" (Foster 156). Only now that it is too late does Eliza willingly and vocally choose to "submit" herself to God; the outcome is inevitable, as any reader of this seduction tale would have known in advance. Eliza must die because she has already forfeited the possibility of salvation, and her death forfeits the possibility of her continued agency as well.

Because Eliza's direct voice in the epistolary form is so much more threatening than Charlotte Temple's indirect one is in her traditionally narrated novel, and because Eliza refuses to submit voluntarily to the republican notion of salvation in an "affectional and voluntaristic"" marriage, her child cannot live as Charlotte's was able to. Eliza hopes for the possibility of her own salvation, as aforementioned, and she also expresses hope for the possibility of her child's salvation when she writes to Julia, pleading: "But should I be called from this scene of action; and leave behind me a helpless babe, the innocent sufferer of its mother's shame, Oh, Julia, let your friendship for me extend to the little stranger! Intercede with my mother to take it under her 
protection; and transfer to it all her affection for me; to train it up in the ways of piety and virtue, that it may compensate her for the afflictions which I have occasioned!” (Foster 156). Eliza, however, has already left the "scene of action"; she left it when her ability to choose a saving marriage to Rev. Boyer was relinquished by her own decisions. Her voicelessness in the last part of the novel exemplifies this. She and her readers know what the end of her tale must be in order to contain the threat of the novel's direct voicing of true female agency: death for both herself and her child. Her very last words of the novel attest to this:

And now, my dear Julia, recommending myself again to your benevolence, to your charity and (may I add?) to your affection; and entreating that the fatal consequences of my folly, now fallen upon my devoted head, may suffice for my punishment; let me conjure you to bury my crimes in the grave with me, and to preserve the remembrance of my former virtues, which engaged your love and confidence; more especially of that ardent esteem for you, which will glow till the last expiring breath of your despairing...Eliza Wharton. (Foster 156)

So ends the life of Eliza Wharton and that of the physical result of her seduction, her "crimes," her child. Her power, however, as an emblem of the possibility of female selfhood and agency, remained to influence female readers throughout antebellum New England. The popularity of this novel, "which appeared in ten editions from 1797 to 1866," and of the real-life tale of Elizabeth Whitman, endured (Waterman 325). It was dramatized in plays, poets like Henry Wadsworth Longfellow “mentioned it as late as 1849," “her [Whitman's] wax likeness circulated among New England towns through the early nineteenth century," and, "during the nineteenth century, the headstone and footstone placed there [at her grave] in 1789 by her friends were gradually chipped away until the epitaph was obliterated and only a pathetic stump of soft, 
red freestone remained," according to Bryan Waterman (326). Had this text simply been one only to reify and reinforce cultural, political, and religious stereotypes, it would not have stood out amongst so many others that already performed that function. Instead, Eliza's direct voice spoke to the possibility of imagined female agency for her readers in a way that capitalized on the real-life tale and kept it alive until stronger female models could be relied upon to exert their influence. Eliza/Elizabeth's story would not have found such endurance in popular culture if it could not have offered female readers something that was often lacking in their own day-to-day lives: the vicarious possibility of imaging their own acts of agency and developing selfhood. 


\section{Chapter Three: Kelroy's Problems with Republican Motherhood}

\section{Introduction}

Cathy N. Davidson's Forward to the Oxford edition of Rebecca Rush's 1812 novel Kelroy situates that text in relation to the publication of two of the most well-known, popular ones of that time: Jane Austen's 1813 Pride and Prejudice and her 1816 Emma. Davidson states that, much like Austen's works, Kelroy was also “preoccupied with the relationships between love, marriage, and money" (v). Notwithstanding this comparison, Davidson acknowledges that Kelroy is "more cynical than any of Austen's novels in its depiction of women as players and stakes in the matrimonial poker game" and further contends that it is "unrelenting in its critique of a society motivated, from the highest to the lowest levels, mostly by greed" (v). Whereas Pride and Prejudice ends in a happy marriage, though, Kelroy ends in the death and destruction of virtually all of its principal characters. Near the conclusion of Pride and Prejudice, Elizabeth Bennet asks Mr. Darcy “to account for his having ever fallen in love with her," and he responds that he fell for "the liveliness of [her] mind"; she tells him that he "may as well call it impertinence at once" (352).

While Elizabeth Bennet’s “impertinence” (and its defining characteristic of being what she later calls "so unlike" most other women of her time) may have been confirmed as an acceptable, or even desirable, female trait by virtue of her eventual favorable marriage to Mr. Darcy, it is not an attribute commonly found or valued among female characters in late eighteenth- or early nineteenth-century American women's novels; certainly, any such "impertinence" contributed to the downfall of characters like Charlotte Temple or Eliza Wharton. Indeed, American female characters did not begin to model directly the type of 
"impertinence" that ironically allowed for the reinscription of patriarchal marriage values displayed by Pride and Prejudice and other British works of that ilk until the heyday of popular American women's novels in the 1850s when characters, like Gerty from Maria Susanna Cummins' The Lamplighter, rely on that quality to enable their rise from poverty-stricken orphan-hood into a happy, financially stable marriage. How, then, did these American novels, mostly written by women and read primarily by women, begin to make the move from the negative didacticism inherent in novels of seduction (as they ostensibly encouraged readers not to model the female protagonist's behavior) into the era of overtly positive didacticism that presented female protagonists as ideals of feminine virtue and behavior as seen in the novels of domesticity so popular in the 1850s? Sometime between the 1794 publication of Charlotte Temple and the 1850 publication of the novel that has been said to have "initiated the very concept of the best seller" (Baym Woman's Fiction 140)—Susan Warner's The Wide, Wide World - cultural expectations for "woman's fiction" shifted from producing works that recounted cautionary tales of seduction that demonized female behavior to ones that instead looked to valorize women as the ideal emblems of virtuousness in the era of domesticity.

Kelroy can be read in retrospect as one novelistic representation of the transition between seduction narratives and domestic ones in that it exemplifies many of the shifting cultural and religious norms at work during this time. In Kelroy, several of the traditional circumstances of the novel of seduction are set up in the beginning, but its customary expectations are either frustrated, inverted, or altogether absent. In terms of plot, it initially sets up several conventions common to seduction narratives, like the death of the young woman's father and her subsequent encounter with a handsome young man, only to reverse the expected outcomes of them. The roles of certain emblematic characters-like mothers, potential seducers, or the female 
protagonist — are similarly upended in this tale; in particular, Kelroy complicates or overturns notions of republican motherhood by featuring a mother whose attempts at nurturing destroy her daughter's life. Finally, the customary social milieu of most seduction narratives would have employed religious discourse as a means of circumscribing the behavior of the main characters, but Kelroy's narrative world rarely includes such language.

So, although Kelroy engages with many of the usual conventions of seduction narratives, it seldom conforms to genre expectations, which makes it difficult to classify; some critics, like Dana D. Nelson, have called it a "tragedy of sensibility," while others, like Davidson, have referred to it as a "Gothic plot" in which "the chief horror...is Emily's mother" (Forward v). The tensions between these two modes play out throughout this narrative and contribute to the disturbing air of uncertainty that pervades it. In her Introduction to Kelroy, Nelson argues that Kelroy and Emily's tragic flaw is the "inability to assess the character of those closest to them" (xviii). This summation of the central tragedy at the heart of Kelroy also accurately describes the usual tragic aspect of most novels of seduction, at least for the young girl typically at the center of such works: the female protagonist naively trusts a dashing young man and, through a series of supposed missteps, eventually falls prey to his seductive arts, all the while believing that he will ultimately marry her, which he fails to do, which leads to her inevitable death, generally in childbirth. The naiveté in Kelroy, however, is not limited to or contained within only the central young, female protagonist as it is in other novels of seduction. On the contrary, Emily Hammond's would-be suitor, almost exclusively referred to simply as "Kelroy," is also duped by the person whose parental authority he has been conditioned to respect and whose job it should have been at least to attempt to protect and guard Emily in the absence of her father: her mother. Like many seduction tales, the novel begins its story just after the death of Emily's father; unlike 
those typical stories, Emily's mother is not depicted as frail or ineffective or even simply absent as the mothers of characters like Charlotte Temple or Eliza Wharton are.

In reversing the expectations for the role of the mother in seduction narratives, the figure of Emily's mother is able to personify for readers the threat of unmitigated female agency in an era which purported, under the ideology of republican motherhood, to value women as the producers and educators of potential citizens for the new nation. She becomes, in this sense, a gothic horror; indeed, as mentioned, Davidson has claimed the "the chief horror in Rush's novel" to be Mrs. Hammond, the young protagonist's mother (Forward v). Kelroy thus exhibits the key thematic tension between "cheerful ideology and a darker social reality" that Marianne Noble describes as "the central fact of American political life" (178). Noble argues that "The American gothic is above all a psychological genre: it explores the nature of personal identity within the social structures unique to the United States" (170). Kelroy particularly explores the nature of women's identity and their potential ability to develop agency; it considers the consequences of that development through its reversals of stereotypical expectations for narratives of seduction.

Whatever literary modes are being accessed in this novel, they all speak to one central, ideological question about what constitutes acceptable female agency in the new republic. Mrs. Hammond has too much agency, and her daughter Emily, the supposed protagonist of the tale, does not have enough. If Emily Hammond had ever spoken or acted on her own behalf, Mrs. Hammond's unchecked, rampant agency and its consequent horrors would not have led to the demise of all. Also, ironically, if her suitor, Kelroy, had not respected the boundaries of parental authority and had instead encouraged Emily to elope with him as most traditional seducers would have done, then, again, the horrors of the novel would not have gone unchallenged. Kelroy's world is one of opposite extremes wherein Mrs. Hammond models the threat of uncontested, 
unchecked female agency and her own daughter, who might have been able to challenge her mother's authority, instead illustrates the contrasting peril of female subjugation. Therefore, I consider Kelroy as representative of a crucial moment in the precarious political, social, and religious conscience of our early nation, but, more importantly for my concerns, I argue that it also functions as a vital link in the chain of emerging female voice and agency in novelistic discourse in America. In negating the customary moral authority of parents and religion in a young woman's life, Kelroy upends the traditional didacticism of reader identification with its female protagonist and thus leaves the reader without a workable model for selfhood.

Accordingly, Emily's senseless death demonstrates the need for a new model to emerge.

Rebecca Rush was well-positioned to write a novel that dealt with these issues. Although little is known about her life, Rush's father, Jacob, “was an eminent Philadelphian jurist” who, "in addition to his legal work...published a number of pamphlets on such religious issues as the 'character of Jesus' and the doctrine of baptism” (Nelson xiii). Rush's uncle, her father's brother, was Benjamin Rush. ${ }^{1}$ Family letters indicate that Rebecca Rush lived with her uncle and his family in the early 1790s in Philadelphia while her father served a term as a judge in Reading, Pennsylvania, and she visited again in 1804 (Nelson xiv). Rebecca Rush came of age in this prominent family whose patriarchs sought, through their essays and public personas, to infuse republicanism with notions of Christian virtue for the betterment and stability of the new nation. An intellectual environment such as this likely produced in Rush a desire to explore the

\footnotetext{
${ }^{1}$ According to Robert H. Abzug, Benjamin Rush's writings about the future of America as an independent nation "emphasized the need not only to create a republic but also 'to prepare the principles, morals, and manners of our citizens' so that they would honor and defend it. Only if the very fiber of everyday personal and social life were imbued with a common set of republican values and virtues, he believed, could the great experiment succeed" (221). Abzug also argues that in the decade after the Revolution, when most leaders "recognized that the translation of revolutionary zeal into a republican reality" meant the "creation of a new political structure," Rush "developed a reform program to remake individuals and institutions into perfect reflections of republican virtues. He shared the view of many that constitutions and simple freedom would not eradicate the darker side of human nature. Rather, one must start with programs that from birth to death encouraged virtue and built a true republic from the individual outward to society" (229-30).
} 
ramifications of republicanism and Christian virtue in her own writing. Kelroy suggests that Rush found the options for women to participate in the making of republican virtue uncertain or unstable, particularly in light of the constantly-shifting religious and political environments in the new nation. Benjamin Rush, in whose household she had spent a great deal of time, notably advocated options for women's education in the new nation. ${ }^{2}$ He also broke ties with the Presbyterian Church in 1787 because he had become "increasingly convinced that salvation was possible for all humankind, and that the Calvinist doctrine of limited election was antirepublican" (Abzug 239). Likewise, many of Jacob Rush's writings emphasize the personal nature of sin and the ability of the sinner to choose to sin and to repent, which suggests that he too had turned away from Calvinism. ${ }^{3}$

In featuring a barely-religious, greedy mother whose unsuccessful child-rearing results in one of her daughters marrying only for money instead of affection and another daughter dying, Kelroy reflects uncertainties of republican motherhood. Specifically, Rush depicts republican motherhood as vulnerable to abuses as exemplified by the figure of Mrs. Hammond. Emily Hammond's lack of agency personifies the absence of reliable sources of moral guidance in that society. There is, however, one scene in the novel in which religious discourse plays a significant role; it is employed by Emily Hammond as a means of reconciling herself to a tragic loss in her life. In prayerfully submitting herself to the will of God, Emily is able to exhibit, however briefly, a state of peaceful self control that paradoxically endows her with more self awareness and self confidence than she has at any other point in the novel. This moment

\footnotetext{
${ }^{2}$ Rush emphasized female education but only in that "“The opinions and conduct of men are often regulated by the women in the most arduous enterprises of life"; in addition, he noted that " "the first impressions upon the minds of children are generally derived from the women. Of how much consequence, therefore, is it in a republic, that they should think justly upon the great subject of liberty and government!"' (Abzug 233).

${ }^{3}$ Jacob Rush pursues these themes in a collection of his letters, essays, and lectures, which he published in 1804, entitled, Charges, and Extracts of Charges, on Moral and Religious Subjects, Delivered at Sundry Times by the Honorable Jacob Rush.
} 
prefigures the coming domestic narratives that authorized submission to God as the means of ensuring salvation in this life and the next for their female protagonists. Perhaps in allowing Emily this fleeting moment of peace, Rebecca Rush was extending the slight hope that she, her readers, and women in the new republic might find the same.

\section{A Startling Reversal of Expectations: Kelroy as the Anti-Seduction Narrative}

At the start of the opening paragraph of Kelroy, before any of its principal characters are introduced, the reader is directly spoken to by the unnamed narrator and told that "In all ages and countries, the legends of that soft passion which pervades creation have ever been cherished with peculiar care," and then the narrator proceeds to classify this particular "legend," the story of Kelroy, as one of those many "narratives of love" (Rush 3). The soft, romantic language of this paragraph, which uses phrases like "youthful heart," "congenial hues," and "those sweet, early sensations," invites the reader to "contemplate with delight that semblance of impassioned feeling which adorns the narratives of love" (Rush 3). This opening paragraph seems to imply, then, that the reader can expect a sweet, romantic tale of love; nowhere yet does it hint at the dark horrors that await the trusting reader. Thus, from the very beginning, the presumptively young, female reader is set up to undergo firsthand a parallel betrayal to that which Emily Hammond will endure during the course of the novel. Most novels, and particularly novels of seduction, employ a reliable narrator whom the reader can trust to enlighten him or her as to the true nature of things even when the characters themselves may not be privy to such knowledge; most readers in the early part of the nineteenth century in America would have expected nothing less than truth and honesty from a narratorial voice in a novel of seduction. As we have seen, the matronly narrator's voice in Charlotte Temple comments on and seemingly attempts to guide 
readers' interpretations of Charlotte's behavior almost throughout the entire story; similarly, the reasonable voices of two or three of Eliza Wharton's most cherished friends perform this same function in The Coquette. In Kelroy, however, this introductory paragraph is almost all the reader ever hears directly from the supposed narrator about the events of the story. Unlike the direct, first-person voices of the various narrators in earlier novels of seduction, the narrator in Kelroy moves after this opening paragraph into a third-person, omniscient voice that never again directly addresses the reader and becomes one whose descriptions of characters and depictions of events are told in a seemingly matter-of-fact persona that rarely comments on them in any direct fashion.

The absence of a guiding, protective voice to lead readers into the "correct" interpretation of the plot events and the choices of its characters is the first clue that Kelroy functions outside of or opposite to previously well-established modes of novelistic discourse for tales of seduction; instead, it often sets up the conventional expectations of its readers but then reverses or frustrates them. The reader is left, therefore, much like Emily herself is, to wander the narrative path of Kelroy alone, unaided by an unbiased voice of reason and unable to make sense of many of the most confusing and horror-inducing aspects of the novel. Even at the close of the story, when all of the principal characters are dead, the narrator fails to offer any kind of commentary or closing summary to help the reader interpret the meaning or potential lessons of this story. Absent this guiding voice, the didactic purpose of Kelroy remains unclear and confusing for readers. The sweetly innocent descriptions of "narratives of love" employed in the opening paragraph, in contrast with the total absence of a didactic narratorial voice in the rest of the novel, serves to set up a deeper sense of betrayal for the reader who would normally expect to trust the narrator to 
offer guidance in interpreting the offered narrative in accordance with the social conventions of that time.

Following this opening paragraph, readers are introduced to Emily Hammond, who "was the youngest child of a merchant in Philadelphia, who died before she had attained her thirteenth year" (Rush 3). Here, we can again see several of the conventions of the typical novel of seduction: an innocent "youngest child," from a merchant-class family, on the eve of her adolescence, loses the person who should serve as her guide and protector as she approaches maturity, her father. At this point, based on the usual conventions of seduction novels, we might expect this sentence to continue with a flowery description of Emily; instead, what follows is a description of her father. Normally, fathers in novels of seduction are presented as strong, moral figures whose daughters go astray only in their absence (brought about by a change of circumstance or his death). Emily Hammond's father, on the contrary, was possessed of a character that "led him into extravagancies which were better suited to his pretensions than his capital"; furthermore, he "had lived in a style which procured him the reputation of immense wealth, whilst his enormous expenses prevented him from accumulating such a fortune as could alone have rendered such blind profusion excusable" (Rush 3). From the very first page of the novel, then, readers may contrast the dreamy depiction of "narratives of love" with the grim reality of its protagonist's circumstances in life. Rather than prudently "accumulating such a fortune" as his opportunities in life and talent may have allowed, and as most fathers in novels of seduction would have attempted to have done in order to secure their family's well-being for the long term, Emily's father squandered his money merely for a showy "reputation of immense wealth."

To make matters worse, this description is followed by one of Emily's mother: 
...at his death the regret of his widow was greatly augmented by a prospect of comparative indigence, which suited neither her habits nor her temper. She was a woman of fascinating manners, strong prejudices, and boundless ambition, which extended itself to every circumstance of her life, and had prevented her from marrying until she was near thirty; consequently at the time of her husband's decease, she was too much on the wane to hope for a second advantageous connexion of that nature. Still she retained an unabated relish for show and dissipation, which her knowledge of the world, on which she prided herself much, taught her could only be obtained in future, by concealing as much as possible the alteration of her circumstances. (Rush 3-4)

Mrs. Hammond is not, therefore, akin to the weak and ineffective but well-intentioned and morally upright mothers found in novels like Charlotte Temple and The Coquette. In fact, she herself can be read as a gothic terror version of what may have happened had a character like Eliza Wharton, who also delayed marriage in her youth in favor of seeking other opportunities, been able to marry Major Sanford early in their relationship. Certainly, they could have lived a similar life of dissipation and only surface-level monetary success made for show and reputation rather than for quiet moral contemplation and prayer, like the one offered by Reverend Boyer, which also could have ended in Sanford's death and Eliza's incurrence of all of his debt, which would in turn have been visited upon their hapless offspring. Indeed, had Eliza been more truly selfish and Sanford more financially able to marry at the time when he met her, we could envision the circumstances of Emily Hammond's life as being very similar to those of Eliza and Sanford's potential daughter. 
In presenting a female main character who, rather than choosing to go astray from a life carefully constructed by her parents to have mostly virtuous opportunities, instead must make her way back to a moral life from circumstances seemingly designed to set her on a path of illicit self destruction, Kelroy once again reverses the norms of standard seduction narratives. The horror of this situation ironically serves to allow female readers the chance, for one of the first times in the history of American women's novels, to identify with the main character as she struggles to overcome her life circumstances and make moral choices rather than against one who seeks to reject or circumvent the moral opportunities already set up for her by loving model parents. In several key moments of her story, Emily makes the choice to remain obedient and stay on the moral path rather than deviating from it as she had the opportunity to do, even when such choices go against her "heart" or her "nature." In the first chapter of the story, Emily and her older sister Lucy are both described for the reader. As the older daughter, Lucy had already entered her adolescence at the time of her father's death, which implies that she had already been indoctrinated into her parents' world of greed and materialism and had been privy to life in high society in Philadelphia. Indeed, despite being "tall, and well made," and "beautiful," readers are told that Lucy's "heart was cold, and her understanding warped by the pernicious principles which had been instilled into a mind originally selfish," and that she "was guided in her distinctions solely by a view to her own advancement, and discovered not the smallest preference for any one human being, however amiable, who was not blessed with the requisite passports to her favour, of either fortune, fashion, or connexions" (Rush 6).

Emily, on the other hand, was closer in age to innocent childhood at the time of her father's death and thus seems to have escaped exposure to those "pernicious principles" during the vulnerable years of early adolescence that her sister had already entered. Her mother took 
both girls out of public society in urban Philadelphia following her husband's death and retreated to the country, "under pretence that she was incapacitated by grief from enjoying as formerly, the pleasures of society," thus permitting her "to continue to her benevolent friends the appearances of undiminished affluence" (Rush 4). Doing so allowed Mrs. Hammond time to prepare her daughters to make wealthy marriages and consequently ensure her own future fortunes while still conserving the small inheritance she had remaining after paying off her husband's debts in full. In a "small, but elegant residence in the country," Mrs. Hammond attempted to educate her daughters to re-enter society at such a time as they were both of an age to make advantageous marriages; for four years, Mrs. Hammond "spoke of the pleasures of wealth, and...she particularly inculcated on them as a leading truth, that those persons who were eminently unfortunate, became so wholly through their own imprudence, and deserved thenceforward to be universally shunned and forgotten" (Rush 5-6). Perhaps it was the country setting away from the allure of city society, or perhaps it was the absence of her father's influence, or perhaps it was simply Emily’s “nature” as Mrs. Hammond later laments, but, for whatever reason, Emily is presented in the first description of her as having grown during her adolescence to be the complete opposite of her sister Lucy. Indeed, when Mrs. Hammond decides to move back to her house in Philadelphia (which had been rented out for those four years as a source of income), "she perceived with astonishment the striking contrast of their [Lucy and Emily's] dispositions, which the seclusion in which they had lived during their approaches to maturity had hitherto concealed from her" (Rush 6). In addition to such physical traits as a "fine complexion," "glossy hair," and "large eyes, of a deep blue," Emily is described as having a mind of "the highest order" and "keen perceptions" that are "happily blended with sweetness and equanimity of 
temper," but, readers are specifically told, she had "none of those unpleasant variations which are usually attendant on strong sensibility" (Rush 6).

This depiction thus sets Emily up as a new kind of female protagonist who stands in contrast to previous young women in novels of seduction. From the first chapter, readers are meant to see her not as someone whose first passionate feelings or "strong sensibility" might lead her astray, as happened with Charlotte Temple and Eliza Wharton, but as a resilient, intelligent young woman who is not prone to extreme emotions. Moreover, Emily "felt that she had a heart, nor could all the sages assurances she had heard to the contrary [from her mother] prevent her from believing that excellence was not always the companion of prosperity" (Rush 7). Finally, readers are told that Emily's “expressive countenance, her numerous accomplishments, the harmony of her voice, and the peculiar gracefulness of her motions, threw a sort of romantic charm around her, which extended to her slightest word, or action, and rendered her uniformly the first object of admiration wherever she appeared" (Rush 7). The depiction of Emily as not only beautiful but also sensitive, intelligent, and even-tempered shows her to be, from the beginning of the story, a very different kind of protagonist than either Charlotte Temple or Eliza Wharton, or any of their kind.

In traditional seduction narratives, a character depicted as Emily Hammond is would have stood as a foil to the behavior and choices of the main character, and the development of a romantic story in which the female protagonist remains obedient to the will of parental authority would have been inconceivable. Emily's story reverses the usual expectations of a tale of seduction by describing a young, female main character who acquiesces to parental authority even when it contradicts her own beliefs and desires. Readers know early on that Emily's nature is quite different from that of her mother and sister, and, more importantly, that Emily herself is 
aware of the difference. For example, when Lucy and her mother prepare for a grand ball that will show off the daughters to all of the eligible men in town, a ball that takes place on George Washington's birthday (which underscores the notion that the marriage market into which they are entering is somehow a national event), readers are told that "Emily beheld all this with a sensation very like contempt" (Rush 12). Nevertheless, Emily acquiesces to her mother's wishes and attends the ball, and her sister Lucy manages to snare the affections of "an Englishman of fortune," Mr. Walsingham, at the event. Walsingham is everything that Lucy and her mother could have hoped for in a potential suitor as he is "lord of a good estate" (Rush 15), from "an ancient, and respectable family," and is "possessed of an independent fortune" (Rush 18). Later in the story, Walsingham will prove to be kind-hearted and generous in addition to his material attributes; unfortunately, he makes the mistake of assuming that Lucy's "commanding form" and "noble features," as he calls them, are merely the outward manifestations of an inner beauty. He realizes his error only after marrying her.

This mistake represents, in miniature, one of the tragic lessons of this tale: that outward appearances, whether of wealth or of beauty or of kindness or of parental affection, may or may not necessarily correspond to true inner ones. What is truly terrifying is that the story never offers a solution to readers or shows them a method by which they may hope to develop a keener ability to differentiate between outward appearances and inward realities. Normally, religious discourse might have been preached to characters and readers alike as a means of developing an ability to measure the true nature of others, as we saw in earlier seduction tales like Charlotte Temple or The Coquette. As I shall examine later, the absence of this traditional religious discourse is another feature of the particular horror that this story exemplifies for its readers. 
Despite Emily's apparent “contempt” for the previous day's events, she nevertheless persists in her belief in the possibility of true romantic love. She embodies, then, the hope for what Jay Fliegelman has termed "affectional and voluntaristic marriage," as was related in my previous discussion of The Coquette; Fliegelman contends that "The struggle for American independence and for subsequent federal union was intimately related to, and ideologically reflected in, a national affirmation of the sacred character of affectional and voluntaristic marriage" (129). Indeed, the plot of Kelroy itself seems to affirm this notion because only a few days after this party (held on George Washington's birthday), which brought to the forefront all of the lessons Mrs. Hammond had struggled to impart upon her daughters (and which Mrs. Hammond and Lucy considered to be a great success because Walsingham arrives to declare his intentions to marry Lucy the very next day), Emily meets Kelroy for the first time. Before she herself sees him, he is described to the reader as being quite different from other young gentlemen, which would have indicated to readers his ideal fitness for becoming a suitor to the young Emily.

By setting him apart from the typical nature of most of his kind, Kelroy's differences signify his suitability to pursue the ideal affectionate marriage for which Emily alone seems worthy. The first depiction of him is as dark, brooding, and unaffected by the usual "charms" of "young ladies" (Rush 26). When a friend of his, "Mrs. S.," attempts to convince him to dance and "asked whether some good music would not assist in raising [his spirits]," Kelroy replies, “"Perhaps not." She then asks him, “'What, not if it pleased you, sir?"” Kelroy's response to this seemingly simple inquiry emphasizes his worthiness as an ideal potential partner in for the virtuous Emily; he says, “'What pleases, does not always enliven"” (Rush 27). This unassuming statement of Kelroy's encapsulates the didactic notion present in many other examples of 
novelistic discourse from that era: that pleasure for its own sake is evil while that which expands the mind or spirit (which "enlivens") is to be pursued and considered moral. Kelroy's brief but significant statement, coupled with the description of him as a "very handsome" man whom the "young ladies" wished to attract, solidifies his positioning in the novel as both the epitome of a romantic ideal and as the opposite in character from the typical seducer in novels of this era.

In featuring an exemplary male character that is not a father figure but rather a romantic one and who is to be admired for both his physical and his spiritual or moral attributes, Kelroy combines the best of the usual expectations of novels of seduction wherein the male suitors are either handsome or morally admirable but almost never both. Montraville, Charlotte Temple's seducer, is quite physically attractive but, despite a professed desire to act morally, never actually behaves in an upright way until after her death. Reverend Boyer, who is virtuous and earnestly wishes to marry Eliza Wharton, has none of the surface-level appeal of his handsome rival, Major Sanford; Sanford, on the other hand, has all of the superficial characteristics most young women would have found alluring but none of the spiritual graces necessary to ensure a lasting marriage. So, in reversing the usual expectations for the leading male suitor in this way, Kelroy temptingly offers the possibility of a story that may fulfill a female reader's hopes for a successful marriage based on mutual affection.

Following this exchange, the little get-together eventually breaks up, and it is not until the next day that Emily actually meets Kelroy. Their meeting comes about because Mrs. Hammond and Lucy decide to go out shopping while Emily chooses to take a walk with Helen in "some of the gardens on the outside of the town"; along the way the two young ladies encounter Walsingham walking with Kelroy, whom he had apparently known since sharing a ship with him when traveling from England to America. (Importantly, Kelroy is not, however, British; he had 
been visiting Europe as many well-off American youths of that time would have done. He is therefore set apart from Walsingham, who is British, as the potential fulfillment of a distinctly American romantic ideal.) Emily's seemingly fortuitous decision to engage in an "enlivening" activity rather than participating in the consumerism of her mother and sister appears to be rewarded in her first meeting with "Mr. Edward Kelroy": “...she was much struck with the elegance of his language, and the similarity of his feelings and sentiments to her own" (Rush 345). Emily is fascinated with Kelroy, and when Walsingham asks her later that evening, "“How she liked his friend?" "Emily expressed without scruple the opinion she had formed of him" (Rush 35). Walsingham playfully tells her that he had not introduced the two of them sooner because he feared that if "II suffered him to come within the reach of your fascinations, he might get to the altar before me"”; Emily laughs and responds that she "“presumed he must be possessed of wonderful attractions, since his success was considered as a matter of course?"” Walsingham enthusiastically verifies her assessment of Kelroy but also hastens to explain to her that Kelroy is "somewhat depressed at present, in consequence of a sudden change of fortune" (Rush 35).

This "sudden change of fortune" in the traditional male suitor in a seduction novel would have likely been the result of that man's irresponsible, immoral, and greedy behavior (such as losing money at gambling or running up too many debts as he attempted to live above his means); additionally, this lack of "fortune" was often the means by which a seducer would have justified his decision to seduce rather than immediately marry the object of his affections. Kelroy's misfortune, however, is neither the result of his own careless behavior nor the means by which he attempts to seduce Emily. Instead, it is the fault of his father, a fact that once again sets readers up to experience the disappointing betrayal that comes about when typically responsible 
characters, like a main character's parents, behave in ways opposite to the standard norms of the models found in seduction novels. In most seduction narratives, the elder generation is the stable, moral, upstanding one and the younger generation (both male and female) rebels against the surety of mirroring that behavior in order to pursue a life of "pleasure" and "dissipation." Once again, however, Kelroy reverses those customary models by depicting the parents of its romantic pair as the irresponsible, thoughtless, greedy, and immoral ones. Walsingham tells Emily that Kelroy's “"father, whose only child he was, had been induced during his absence [in Europe], to embark in a wild speculating scheme, which he fancied would at least double his property, but on the contrary it failed, and ruined him."” Consequently, "'He lost all he was worth except about two hundred a year ...Grief, and disappointment at length destroyed his health, and on Kelroy's return to America, six months ago, he found his father dead and his affairs in the utmost perplexity and confusion"” (Rush 36). Despite this bitter misfortune, Kelroy does not wallow in his financial difficulties and thereby use them to justify any potential, subsequent, immoral behavior; rather, he embarks upon a plan to journey to India and attempt to rebuild his finances. ${ }^{4}$ His only reason for remaining in town is to visit his mother and assure her well-being before his departure. It is at this point that his path crosses that of Emily's and their romance begins.

Had Emily been truly indoctrinated in her mother's teachings regarding wealth and marriage, she would have, at this moment, avoided any further meeting with Kelroy and rejected any advances he made towards her. The fact that she fails to do so stands as one of the only examples in the entire novel of Emily not obeying her mother's wishes. In fairness, at this point in the novel, Emily truly believes that her mother has her best interests at heart and so she may

\footnotetext{
${ }^{4}$ Around this time, India begins to appear in women's novels as the means of making a fortune for many a romantic young, male protagonist. During the heyday of women's writing in the $1850 \mathrm{~s}$, several male characters made the journey, including, for example, Gerty's beloved Willie in Maria Susanna Cummins' 1854 novel, The Lamplighter.
} 
not consciously realize that, in choosing to follow her heart, she is also choosing to disregard her mother's wishes. Ironically, it is this very failure that marks her as a more morally-developed character than her previous counterparts, Charlotte Temple and Eliza Wharton. In acting in a way that allows for the possibility of an ideal romantic love to take precedence over her mother's assertions that a successful marriage must be based on fortune, Emily defies her mother's wishes for what she and her readers would regard as moral reasons; in other words, her act of defiance is performed to illustrate for readers the rightness of a potential marriage based on love and conjugal compatibility rather than only on economics.

Whereas in Charlotte Temple and The Coquette a lack of financial stability served as the means of displaying the consequences of poor decision making on the part of the suitor, and of highlighting the horrible outcomes for the female protagonist who went against the wishes of her well-meaning parents and friends, in Kelroy that same financial instability's function is reversed to allow a young, female character to model moral behavior by valuing love and affection over consumerism. Emily does not voice this decision to any other character, nor does she seem to be consciously aware of it as she "experienced in the society of Kelroy a pleasure wholly new": "Without seeking to analyze her feelings, she thoughtlessly resigned herself to a novelty [first love] which extended its bewitching influence to every impulse and idea" (Rush 39). Therefore, even though Emily does act to defy the explicit dictates of her parental authority figure, her mother, her behavior is excused by the fact that she does so unconsciously, as she is swept up in the experience of love for the first time. Unlike the choices of her literary forebears, Charlotte and Eliza, Emily's are made in defiance of, rather than compliance with, immoral demands based on selfishness or greed. 
Even though it may appear initially that Emily seeks to gratify her "every impulse and idea," much as a typical young woman in a seduction novel would, the remainder of the novel emphasizes two crucial distinctions that set her behavior apart from that of her predecessors: one, that the love between Emily and Kelroy is morally righteous and thus desirable, and, two, that the demands of her parent are immoral and based in selfishness rather than in a sincere longing for the well-being of her child. Emily's defiance of authority in the face of her usually submissive and obedient behavior is an early example of the conduct that will come to typify that of heroines in future domestic women's novels in mid-nineteenth-century America. As such, it stands as an important turning point in the development of female agency and self-identity in American novelistic discourse. As shall be seen, Emily's growth as an individual does not progress to the point that she is able to choose to defy outright the wishes of her mother; it does, nevertheless, point the way towards future novels, written for women and by women, wherein young female characters may begin to model moral behavior even in the face of overwhelming conditions that seek to subvert those virtuous impulses.

Thus, in all of the ways here enumerated, the story of Emily and Kelroy's romance is depicted from the beginning as antithetical to the traditional plots and characterizations of earlier seduction novels. As their story continues, so too do the reversals of expectations for their behavior continue; however, for the remainder of the novel, the choices of these two characters are all made in relation to the behavior of the person who may function in actuality as the central character in the novel, Emily's mother, Mrs. Hammond. For, immediately upon learning of Kelroy's interest in her daughter and, concurrently, of his situation in life, Mrs. Hammond declares, “"That it [Kelroy and Emily’s marriage] most certainly never will [take place], whilst I live!"' (Rush 40). In order to continue to explore the ways in which Kelroy functions as an anti- 
seduction narrative, then, we must study the role Mrs. Hammond assumes in bringing about the tragic outcomes of the novel.

\section{Mrs. Hammond and the Terrors of Republican Motherhood}

Despite her overt maneuverings to influence her daughters' characters and affect their futures, and regardless of her success in molding her daughter Lucy in her own image (and thereby marrying her to an English nobleman), Mrs. Hammond is not a model of idealized republican motherhood based on Linda Kerber's seminal definition of the term. ${ }^{5}$ Mrs. Hammond's dissimilarity from this model is highlighted if we recall that Kerber claimed that "The Republican Mother was a device which attempted to integrate domesticity and politics"; she contended that that integration hinged on "the expectation of continued deferential behavior among women" (203). ${ }^{6}$ Should a strong-minded or educated woman seek more than this deferential role, it would constitute a "visible threat to this arrangement," according to Kerber (204). Mrs. Hammond, Emily's mother, exemplifies for readers the consequences of unmitigated maternal authority by showing exactly what happens when the person to whom a

\footnotetext{
${ }^{5}$ When Kerber coined the phrase, "The Republican Mother," she also characterized most intellectual women of the time as "consumers, not creators of Enlightenment ideas" (188). According to Kerber, while much of Enlightenment philosophy spoke of women, if it spoke of them at all, as having little or limited participation in the "political community," the political ideology developed in the new American republic and based in part on that philosophy did include a sort of "political role for women": "It made use of the classic formulation of the Spartan Mother who raised sons prepared to sacrifice themselves to the good of the polis. It provided an apparent integration of domestic and political behavior, in a formula that masked political purpose by promise of domestic servitude" (188). Indeed, she delineated the "alternate model" of political involvement that she says was developed in the 1790s by "Judith Sargent Murray, Susanna Rowson, and Benjamin Rush"; Kerber defined this new model as follows: "The model republican woman was to be self-reliant (within limits); literate, untempted by the frivolities of fashion. She had a responsibility to the political scene, though not to act on it...Her political task was accomplished within the confines of her family. The model republican woman was a mother" (201-2).

${ }^{6}$ Much as citizens of the new republic were asked to surrender voluntarily their own direct involvement in democracy by electing officials to represent them in the new government, Kerber stated, women were expected to model this "deferential behavior" within the home. She noted that "The voters of colonial Virginia did not think themselves good enough to stand for election but they chose legislators; the deferential women whom Judith Sargent Murray prescribed for the republic did not vote, but they took pride in their ability to mold citizens who would" (203). Finally, Kerber contended that the development of "egalitarian democracy among men" was dependent upon "continued deferential behavior among women" (203).
} 
wife (or a citizen) defers is removed. Having no sons, brothers, uncles, or future suitors to whom she can defer after the death of her husband, Mrs. Hammond alone is left in charge of her daughters' well-being; her rampant, unchecked behavior mirrors in miniature early nineteenthcentury fears regarding the potential political dangers of women (or individual citizens) having direct, egalitarian participation in the democratic process. When a woman is left in charge of her familial state, a scaled-down model of the political one, without the guiding hand of a man to whom she must defer, Kelroy's gothic tale enacts the consequences of that situation for both its main characters and its contemporary readers. In addition, Kelroy suggests that the absence of any model of acceptable female agency results in a world of horrors which no one can survive.

Unlike earlier model mothers in novels of seduction who were ineffectual in their quests to raise an obedient daughter but who still remained deferential to patriarchal norms and ideals, Mrs. Hammond is depicted as neither a model of morality nor of motherhood nor of meekly deferential female matrimonial behavior. She is, however, quite effective at molding her older daughter, Lucy, in her own image, and readers are almost invited to admire her cunning and determination as she takes charge of her financial and familial situation following the death of her husband. However, rather than suggesting that her apparent agency could be a positive model for female behavior, the consequences of her choices take on the characteristics of a gothic horror story as she brings about the death and destruction of her family and herself. Her position in life and her personality both read, then, as antithetical to the common ones usually found in ineffectual mothers in seduction narratives.

Upon being told of Emily and Kelroy's mutual interest, as noted earlier, and being informed concurrently that "“[H]e is not worth a cent, you know!"” (Rush 39), Mrs. Hammond denies the possibility of her daughter's engagement to Kelroy and demands, "II hope you 
contradicted it immediately?"” Mrs. Cathcart replies, "'That I did! and told them that I was very sure it would never take place on earth."” Mrs. Hammond responds, "“That it most certainly never will, whilst I live!'” (Rush 40). Once Mrs. Cathcart leaves, Mrs. Hammond prudently realizes that this situation has arisen as a result of Walsingham's close friendship with Kelroy. Lucy has not yet married Walsingham at this point in the story, so Mrs. Hammond does not feel free to "banish him[Kelroy] from her house... as it could only be done at the risk of exposing herself, and offending Walsingham"; nevertheless, "she contrive[ed], apparently without design to separate her [Emily] from Kelroy as often as they were placed near each other, and thus effectually prevented for the time, that exclusive intercourse for which, to her great dismay, she discovered them to be mutually solicitous" (Rush 40-1). Following this, Lucy and Walsingham are married, and, at the reception party for their wedding, Emily is able to take a moment to reflect on her own circumstances.

The reality of Emily's older sister's marriage seems to have encouraged in her a new ability to assess accurately, with considerable wisdom and insight for a young female protagonist, her own condition: "She saw Lucy, cold, and heartless, in possession of the undivided affections of an amiable man, whose worth she was incapable of appreciating, and mistress of immense wealth which she would never employ to any better purpose than the attainment of luxury or fashion; and whilst Walsingham was thus cheated into a union...Kelroy and herself might waste the bloom of life in pursuing hopes, which if unsuccessful, would embitter the remainder of her days (Rush 43). Of Kelroy, she notes that "In his character was combined all that appeared to her worthy of estimation, and she contemplated this living image of her own cherished standard of excellence, with indescribable emotions both of pleasure and 
pain...his depressed situation, and her perfect knowledge of her mother's views, convinced her that she ought, if possible, to banish him entirely from her thoughts" (Rush 42-3).

Unlike most of the young women in previous seduction novels, then, Emily is attracted primarily to Kelroy's "character" rather than to his physical appearance, his ostensible fortune, or his fun-loving nature. At the same time, the wedding seems to help Kelroy to awaken to the realities of his situation as he considers, "how improbable it must appear to the eye of common reason, that situated as he was, despoiled of his property, and preparing for a long voyage, from whence he might never return, he should suffer himself to become seriously attached to a beautiful young woman" (Rush 44). Yet, unlike previous young, male characters in novels of seduction, Kelroy is not attracted to Emily's surface-level qualities alone: "her luminous mind, and inimitable manner, adorned with all those touching graces, which from being rarely seen are believed to exist only in imagination, rendered her in his estimation the most perfect of her sex, and filled him with emotions which quickly resolved themselves into deep regret, and unalterable passion" (Rush 45). Significantly, though, Kelroy also deviates from the norms of behavior found in novels of seduction when her realizes that "his affection could only be equalled by his distress at the idea of being in a situation which precluded every hope of obtaining her hand, except on clandestine terms"- - terms that are unthinkable to a man of "character" like Kelroy (Rush 45).

Thus, both Emily and Kelroy come to the same silent conclusion that they cannot pursue a relationship; such a mature, conscientious, and selfless decision would not have been made by the type of romantic couple generally seen at the forefront of a woman's novel in the early republic. Nevertheless, despite their best intentions, they cannot help but be in one another's presence as her sister and his best friend are now married. Soon, Lucy and Walsingham will 
leave permanently for his home in England, where they are to reside, and the lovers' paths will not need to cross with such frequency. In the meantime, however, Mrs. Hammond grows increasingly distressed at the obvious feelings that have developed between Kelroy and Emily.

However, Mrs. Hammond realizes she must defer to Walsingham in this and other matters if she hopes to someday capitalize on her relationship with her new son-in-law and also marry Emily to a similarly-situated man: “...the restraint in which she was held by Walsingham, whom it behoved her not to offend, enabled her to look forward with something like consolation to her separation from Lucy, after which she should be at liberty to act as she pleased, and drive from her presence this hated innovater [Kelroy] of her repose" (Rush 46). Walsingham believes, because he has "judged only from appearances, and was a stranger to the hidden motives which actuated this selfish imperious woman [Mrs. Hammond]," that "both Lucy and Emily were entitled to a share of property which was withheld from them by the arbitrary disposition of their mother" (Rush 46-7). In other words, Walsingham trusts, along with the rest of this upper-class society, that both daughters have an inheritance coming to them upon marriage from the estate of their father; Mrs. Hammond knows that she must keep up this façade if she has any hope of marrying Emily to a wealthy man of class. Walsingham has been utterly duped by Lucy's physical appearance into believing that her spiritual self is equally beautiful, and he has similarly believed that her appearance of wealth also signifies the real object itself. Mrs. Hammond knows that she must defer to him, now that he is the only male member of their family, until such a time as he is back in England. If she fails to maintain the "restraint in which she was held by Walsingham," all of her secrets will come out, no one of any means will want to marry Emily, and she herself may not be welcomed into Walsingham's home as she hopes to be at some point in the future so that she can live the life of luxury for which she has been working so assiduously 
since her husband's death. Mrs. Hammond also fears that if Kelroy believes Emily to be independently wealthy, and if he has the slightest encouragement to pursue a permanent relationship with her, then he may decide to "declare his sentiments openly," which would be disastrous as Walsingham was "desirous of a pretext for promoting the success of Kelroy"; Mrs. Hammond contrives, therefore, "constantly to detain Emily near her at home, and as constantly to accompany her abroad; and whenever Kelroy was present, insinuated herself into every group where they were placed" (Rush 47).

Here, we see Mrs. Hammond as one who is consciously aware of the fact that she must appear to act as a good republican mother in deferring to the one man in her life when it comes to her daughter's future, yet she simultaneously secretly strives to undermine and subvert that same system to which she believes she must defer. She puts on the façade of a disinterested republican mother who acts in her daughter's best interest: “... so well did she manage her intrusions, that a very skilful observer would scarcely, without some previous clue, have ascribed them to any sinister motive; and whilst Kelroy and Emily were writhing under the restraint which she perpetually imposed on them, Mrs. Hammond appeared to indifferent spectators to be one of the most amiable, and affectionate of mothers" (Rush 47). Mrs. Hammond is thus able to maintain the appearance of being a good mother while she works to prevent an outcome that has been presented as worthy and moral — the engagement of her daughter to a man of character-in order to buy time to find Emily a suitor whose only necessary attribute is wealth and thereby insure her own future life of luxury and ease. This contrast in her appearance as an "amiable, and affectionate" mother versus the reality of her selfish goals sets her up as the antithesis of maternal expectations in traditional seduction narratives and brings to light the gothic horror of a tale wherein a worthy young woman's own mother works to circumvent her happiness in life. 
As Emily is subjected to the constant presence of her mother (which works to prevent Kelroy from openly declaring his affections and intentions), she struggles to reconcile her internal feelings of confusion — over her love for Kelroy and her respect for her mother's wishes - with the outward appearances of Kelroy_-"whose gravity and reserve hourly increased" as he comes to believe his love for Emily cannot end in a happy marriage — and her seemingly loving and devoted mother who refuses to leave her side. This conflict between internal feelings and external appearances is one of the tragic aspects of this tale, and it takes a physical toll on Emily. She falls victim to an unnamed illness: "Unused to these internal conflicts, her appetite failed and her colour faded...A severe cold with which she was attacked, afforded her an unquestionable excuse to indulge [her] melancholy propensity, and confined her wholly to her chamber; where, in a few days, indisposition and anxiety produced a change in her appearance that was seriously alarming" (Rush 47-8). Not until her doctor advises her that a relapse in her condition may have "fatal consequences" does Emily emerge from her room with the knowledge “that she no longer had occasion to seek a pretence for seclusion" (Rush 48). ${ }^{7}$ Emily's illness, despite its oppressive and near-fatal qualities, can be read as a means of allowing her to resist both the power of her lover and the power of her mother and thereby afford herself a quiet space in her own room in which she may enjoy the freedom of avoiding having to choose one over the other. In refusing to choose, Emily's lack of agency in this case becomes a paradoxical type of agency in itself wherein she may indulge her need for a quiet space of her own rather than succumbing to either her lover's or her mother's wishes.

\footnotetext{
${ }^{7}$ Diane Price Herndl, in her study Invalid Women: Figuring Feminine Illness in American Fiction and Culture, 1840-1940, has explained that "women's illness has been seen largely as a result of the oppressive use of male power, as the resistance to oppressive power, or as the means to a kind of power of its own (artistic, political, or 'sentimental')"; yet, Herndl argues that women's illnesses can "stand in all three relations to power at the same time" and that they "can be both redemptive and destructive, resistant and dominated, liberatory and oppressive" (5).
} 
When Emily reappears downstairs, her mother (who had neglected Emily entirely-in favor of gambling at cards with her friends - while she was safely contained in her room and away from Kelroy) refuses to leave her side, purportedly out of an abundance of maternal concern over her health, but in reality because Kelroy has also maintained a watchful presence over one who is now "doubly dear from her recent danger" (Rush 48). Their silent battle of wills comes to an end, however, when Kelroy must leave town for a few days on business. One evening, although Kelroy is due back in town that very night, Mrs. Hammond cannot resist the spectacle of attending and being seen at a large ball and having supper publicly with Walsingham and Lucy; she believes that Kelroy, should he return, would seek out Emily at the ball rather than at home, so she feels relatively safe in indulging herself. Emily stays home under the watchful eye of a servant who has been given strict orders not to let anyone in to see her. The servant, however, believes it is a "pity" that Mrs. Hammond will not let "Kelroy court Miss Emily," and so "his own notions of right...prevailed"; when Kelroy came to the house that evening innocently looking for Walsingham, the servant let Kelroy in and told him pointedly that Emily is “in de parlour quite 'lone” (Rush 49-50). Kelroy finds Emily playing her harp and singing to herself. He calls out to her and, "At the sound of her own name, she started from her chair in wild astonishment, and perceiving him at her side fainted into his arms" (Rush 51).

This scene harkens back to the one in which Charlotte Temple fainted into Montraville's arms or the one when Eliza Wharton fainted after being rejected by Rev. Boyer, and, much like those, it also signifies a crucial turning point in the novel: "'Emily! — dear Emily!'—-said Kelroy, as he held her to his bosom. When she recovered, he besought her forgiveness for the terror he had occasioned her.- - Unable to speak, she endeavoured to escape from him, but he would not suffer her, and avowing his attachment in the most impassioned language, desisted not from 
protestations and entreaties, until he prevailed on her to confess that he was beloved in return" (Rush 51). Like Charlotte, then, Emily acquiesces to her lover's desires (in this case, though, only for love and a promise of marriage, not actual seduction) without speaking a compliant word. Also like Charlotte, the act of fainting gives her suitor the opening he needs to make physical contact with her and thereby prevail upon her to accept him. Kelroy does not literally ride off with Emily as Montraville did with Charlotte, but his insistence is no less forceful and her submission no less clear as she is literally caught in "his arms." Emily's utter lack of voice in this scene is highlighted further by the fact that she has no direct dialogue or exchange of words with Kelroy at any point in it, rendering her silent in the text itself regardless of indications that she may have spoken but that it was not recorded here. He speaks to her, and "mutual inquiries, and explanations ensued," but readers never know specifically what those are or what she may have said.

This absence of textual voice serves two purposes: one, it allows Emily to be seen as still obedient and morally upstanding in that she does not directly voice her disobedience of her mother or even go out to meet Kelroy as Charlotte chose to meet Montraville or as Eliza chose to meet Sanford; and, two, it allows readers a silent space in which they may vicariously imagine the pleasures of exchanging mutual declarations of love with a worthy suitor. In other words, Emily's abject lack of agency works here to her benefit much as her illness had previously; she herself may not be making a conscious choice to benefit from it, but her character performs for readers the simultaneous experience of being both submissive and assertive. After Kelroy leaves for the evening, Emily suffers the consequences of this duality as she "retired to her chamber, where the tumult of her thoughts long kept her waking, and she at last sunk to rest with tears of mingled grief and rapture stealing from her eyes" (Rush 51). "Grief" and "rapture" catch Emily 
in a similar bind to the one which ensnared Charlotte Temple and Eliza Wharton, but her situation is one that also could horrify readers as they realize that, unlike those hapless female protagonists, Emily has wisely chosen a man of character whom most parents would be happy for their daughter to marry. His only fault is that he may not be able to support her in the manner that her mother believes adequate for future success and stability. Therefore, the horror comes not in the form of a disobedient daughter's misplaced choices but in the shape of her own mother as the obstacle to this otherwise worthy marriage.

Up to this point, it may have been possible for some readers to have continued to believe that Mrs. Hammond could have still had her daughter's best interest at heart while she nevertheless indulged her own fantasies of future wealth. This illusion serves as a means of displaying for readers a fantasy of ideal republican marriage so that they may imagine vicariously their own potential marriages to men considered worthy. She and Emily have a frank conversation when Mrs. Hammond learns of the previous night's events. She asks Emily, “'But you will not, surely Emily, bind yourself with open eyes to poverty and distress?"' Emily responds, "II would do nothing rashly...I am very young, and in a few years perhaps his situation may be very different"" (Rush 56-7). Later in the novel, she tells her mother "that she was not quite so romantic as to imagine that love could compensate for the total want of what was generally meant by better things [emphasis Rush's]; but as she was not of an aspiring temper, a very moderate share of them would content her" (Rush 116). Emily's willingness to wait for marriage until such a time as Kelroy is financially stable, and to forego the extravagancies of fortune for which her mother has longed, signifies the shift in women's novelistic discourse from ones in which the fantasy of sexual submission is enacted for readers to imagine enjoying the pleasures of indulging to one in which the fantasy of ideal republican marriage in the new 
American world absent the nobility and class division of England is instead performed.

However, the ensuing events of the novel leave no doubt as to the selfish terrors of which Mrs. Hammond is capable.

Mrs. Hammond realizes that Walsingham will no doubt take up Kelroy's suit now that a mutual declaration of love has been made, and she also knows that she must at least appear to defer to his wishes in this matter as the only perceptible obstacle to Emily and Kelroy's future matrimony would be the delay in his financial stability. Aware of the fact that she cannot make known to Walsingham her desire to have her young daughter married off as soon as possible so that she may indulge her greedy habits of shopping and gambling with impunity, she approaches Walsingham herself, without waiting for him to come to her about the matter as he inevitably would have done. This temporarily gives her the upper hand so that rather than accepting Emily and Kelroy's engagement outright, she instead gets Walsingham to agree that "if the young people should both continue in the same mind, it was possible she might grant them her unlimited consent. At present however, she thought it her duty to guard against accident, by forbidding any engagement on the part of her daughter; and signified that she could permit Kelroy to continue his attentions on no other terms" (Rush 58-9). Walsingham informs Kelroy of "his partial success" and adds that "as the old lady seemed rather more tractable than could have previously been expected, he thought it best to let the matter rest for the present" (Rush 59). Eventually, in a series of events designed to hide her growing debt and substantial lack of income, Mrs. Hammond is forced to agree to an actual engagement between Emily and Kelroy in order to maintain a kind of deference to Walsingham, whom she owes money, and thereby retain her own standing with him. Nevertheless, she only agrees that Emily "shall be united to Kelroy...immediately upon his return from India, provided they both continue to desire it" (Rush 
92). In making such a provision, Mrs. Hammond leaves open the option for either party to break more easily the societal constraints of the usual marriage contract entered upon in a traditional engagement. Of this distinction, as we shall see, Mrs. Hammond hopes to take full advantage. Upon learning of her potential future marriage to her heart's desire, Emily is once again left textually speechless: “Abashed, astonished, and delighted, Emily almost doubted what she heard.- She blushed until her eyes filled with tears, and unable to articulate a syllable, looked timidly at Kelroy for an elucidation of this unexpected command.” Kelroy begs her to give her verbal consent to marry him upon his return from India as her mother has agreed: "“thus sanctioned, you cannot, you will not refuse what I have so often sought in vain?'” Emily, however, still cannot speak. She is caught, literally, between the physical closeness of her mother on one side and Kelroy on the other: "Emily tried to answer, but her emotion was too great for utterance.” Her mother, upon seeing her distress, commands Emily, “'Speak!' cried Mrs. Hammond, in a tone of authority" (Rush 95). Now that her plan has been set in motion, Mrs. Hammond needs Emily to acquiesce to her role in it if she hopes to circumvent it while still maintaining the appearance of goodwill required of her by Walsingham.

Trapped between her habitual deference to maternal authority and the newfound possibility of deferring to her future husband instead, Emily still cannot speak; her aphasia here signifies the lack of agency for women in a culture in which they must defer first to a parental authority and then to a conjugal one. In refusing to speak, Emily resists both choices: "'She cannot,' said Kelroy, pressing her hand, 'the suddenness of this scene has overcome her'” (Rush 95). Mrs. Hammond tries to command her once again: “"Emily, why will you persist in irritating me? This perverse reluctance is beyond anything that I could have conceived possible!'” Thus chastened, Emily finally replies, “'Not from perverseness_-' said Emily at length, speaking with 
difficulty_ 'not from reluctance are these tears — for I have none — however I may be censured for the confession." This is all the encouragement Kelroy needs to assume that Emily has indeed agreed to become his wife upon his return from India even though she has resisted actually uttering the words of consent. He tells her that "'no words - no language, Emily could ever do justice to the feelings of my heart at this moment-but you, who know it best, can best conceive them._-And now-henceforward, you are only mine?_"' Finally, then, she responds, almost reluctantly, "'Yours—-never to be another's,' faultered Emily." Kelroy's textual assertion of the rightness of Emily's voicelessness serves here to afford her his permission to speak, signifying that she has, only at her mother's insistence, begun to defer to him as a wife would. She does not maintain this new position for long, however, because her mother immediately interrupts them and commands her to go upstairs, "until you recover yourself! - you are not fit to be seen!"” when she hears Mrs. Cathcart at the door (Rush 96). When Emily obeys her mother instantly, without so much as a glance at Kelroy, it indicates that Emily is still hers to command, at least for the time being; Emily performs the part of the dutiful daughter and respects her mother's wishes, despite her earlier resistance. Her complete submission to Kelroy as her husband must wait until marriage.

Now that this matter appears settled, Walsingham decides to take Lucy back to England where they will reside permanently in his family's ancestral home. Mrs. Hammond, fearing that her prospects for quickly marrying Emily to an equally wealthy man are now greatly diminished, "had begun to let fall hints of an intention to accompany her daughter, and settle in England, which was utterly distasteful to Walsingham...she received not on these occasions the smallest encouragement” (Rush 65). So, when they leave for England without her, Mrs. Hammond becomes doubly determined to break the promises she made to grant eventually her "unlimited 
consent" for Kelroy and Emily's marriage. Mrs. Hammond admits that she is completely conscious of her own flaws in spending indiscriminately and gambling away the money she had at her disposal; she also knows that her need to appear to defer to Walsingham has left her in a terrible bind: "Deeply did she now regret the precipitate extravagance with which she had squandered in a few months sums sufficient to have supported her for years in comfort, and competence. And more deeply still did she lament the fatal oversight of suffering herself to be controuled by Walsingham." In realizing too late that she has overreached her grasp by scheming to marry off hastily both of her daughters to wealthy men, Mrs. Hammond exhibits consciousness of her own role in past events as well as any future ones and also shows that she knows that if she had allowed Emily to marry Kelroy immediately, making her deferral to Walsingham complete rather than only surface-level, she may have achieved at least some of her selfish goals because then she could have accompanied Lucy to England rather than staying behind with her unwed daughter. Of course, Emily would not have had any inheritance coming to her to help her and Kelroy subsist, but here Mrs. Hammond seems to regret not leaving them to suffer "their fate" so long as she can live with Lucy and presumably impose upon Walsingham for cash as she has already had success in doing: "Believing therefore, their union inevitable if Kelroy returned at the expiration of a twelve month, she grieved that she had not, in the first instance, promoted their marriage, and left them to their fate, by insisting on accompanying Lucy to England" (Rush 100).

Such a direct acknowledgment is further evidence of the gothic horror displayed by this novel; a woman left solely in charge of her own fate as well as that of her daughters, especially in the absence of religion, is the complete antithesis of the ideal republican mother and thus a horror. Having such unchecked power has only served to corrupt her morals further and has 
jeopardized the happiness of most of those involved. On the other hand, if Emily and Kelroy had not felt themselves bound to respect Mrs. Hammond's wishes, perhaps they would have eloped and made their way in the world together. On the heels of these self-revelations, Mrs. Hammond makes the decision to rent her city house and retire once again to the country to escape her creditors and conserve her remaining funds. Ostensibly, Emily believes that this move will be made partially for her own benefit as she has expressed no desire to attend balls or otherwise socialize but would rather demurely and patiently wait on her beloved's return from India, for which he plans to leave soon. However, before they can move out, their townhouse is engulfed in fire and burns to the ground; every single item of any worth whatsoever is lost in this fire save for a small trunk and a few chairs, but all members of the household are able to escape it safely. Lacking in funds even prior to this, Mrs. Hammond had let the insurance policy on her house and its furniture expire just one week before this event; also, she had mortgaged out her country house for its full value, and without the rent from her city house she cannot pay the mortgage, so now she has absolutely nowhere to live. No one knows this except Mrs. Hammond, who must face alone the extreme consequences of her selfish and irresponsible behavior. Indeed, Mrs. Hammond seems to have lost her reason for living now that all of her prospects for wealth are gone: "the renewal of feeling and memory presented a prospect so fraught with wretchedness, that dissolution or madness would have been comparatively blessings" (Rush 124).

Just at this moment, then, when this experiment in unchecked female power and authority that Mrs. Hammond represents seems to be utterly without hope, and, since she has no income to maintain her daughter in a style that might attract a different wealthy suitor, and just when readers may dream that Kelroy will make his fortune in India and return to marry Emily without any further intervention on the part of Mrs. Hammond, Mrs. Cathcart, with whom they have been 
staying, mentions casually over breakfast one day that the fifty-thousand-dollar lottery prize number has been drawn, but " they have not yet been able to find out who it belongs to" (Rush 124). Mrs. Hammond nearly faints upon hearing the number of the winning ticket read out loud - she has Emily fetch the small trunk that had been saved from the fire, unlocks it, and extracts two lottery tickets, one of which corresponds exactly with the number in the paper. This happy event extricates Mrs. Hammond from all of her previous troubles, and, to the hopeful reader, it seems to imply that Emily and Kelroy may be able to be united in matrimony without the necessity of his voyage to India. Mrs. Hammond's utter selfishness and complete disregard for her daughter's happiness in all matters save financial ones is once again showcased, however: "To Kelroy...she behaved with unusual cordiality, but took care to insinuate, that although it was now doubly in her power to remove the necessity of his voyage to India, she approved too highly of that measure to exert the means of preventing it" (Rush 130). Poor Emily, who up until this point labored under the delusion that her mother did indeed care for her despite all evidence to the contrary, now must admit to herself that no such maternal affections exist: "seeing her mother, as she imagined rolling in superfluous wealth, she learnt with bitterness of heart that no part of it was to be appropriated to the only purpose which could render the accession of it valuable to her" (Rush 130-1).

The naïve reader might assume here that Mrs. Hammond, while basking in the glow of her new-found wealth (despite her coldness of heart and selfish refusal to distribute any of her money to her own daughter), might at least refrain from any further attempts to circumvent Emily's marriage to Kelroy. Indeed, in many respects Mrs. Hammond seems to be a changed woman who has been "taught by her past distresses the value of economy" and who "no longer indulged herself in endless company, and expensive entertainments, but contented herself with 
the occasional society of a few of her most intimate associates, and behaved in every respect like a rational woman" (Rush 136-7). She and Emily do move out to the country after all, and there they live a quiet life where Emily's mother "suffered her to dispose of her time exactly as she pleased," which seems to indicate that Mrs. Hammond has relinquished her maternal concerns for her daughter's welfare along with her financial obligations (Rush 137). Emily remains sweetly submissive to her mother's commands, but they do not appear to be ones that threaten her well-being or her future happiness.

This peaceful interlude cannot last, however. Much as many previous female protagonists experienced moments wherein their belief in a future happy marriage may be indulged (during which female readers may have also indulged in the belief in a potentially happy outcome to the story), Kelroy similarly displays this possibility for its readers. In seduction novels, however, the revelations and reversals that lead to the death and destruction of the female protagonist are predicated on her own poor decision making and the despicable behavior of her would-be lover. In Kelroy, those norms are horribly refigured so that the figure whose choices destroy Emily is that of her own mother. After a chance meeting leads to an ongoing but completely innocent friendship between Emily and a wealthy, unwed nobleman named Dunlevy, and seeing that Dunlevy has clearly fallen in love with Emily, Mrs. Hammond, unbeknownst to either Emily or the reader, secretly forges false letters to Emily from Kelroy and to Kelroy from Emily which lead each of them to believe that the other no longer loves him/her and wishes to end their engagement. Emily's will is entirely broken by Kelroy's apparent rejection of her. In a scene that mirrors the ones in previous seduction novels wherein the young female protagonist's eyes are finally opened to the despicable nature of her seducer, she comes to believe again that her mother has had her happiness at heart all along and that Mrs. Hammond 
was the only one who could see the potential for perfidy in Kelroy's heart: "“Mother, you warned, you besought me to renounce the man who has at last made me so wretched, but I refused to listen to you — and I am punished for it.—He had renounced me! [emphasis Rush's]— Left me with all the bitterness of contempt and scorn!- and-I am punished as I deserve!'” (Rush 168). Neither readers nor Emily guess, at this point, that Mrs. Hammond herself has brought about this rejection; indeed, Emily further laments: "“Ah! if I had but listened to —if I had but believed you!... I should not feel as I now do!-But it is fit-it is just that all should have happened thus, and I have no right to complain"” (Rush 170).

Mrs. Hammond's reply to Emily's self-flagellation seems to serve to reinscribe her in her righteous place as the sole bearer of parental authority: "'Say not so,' returned Mrs. Hammond, deeply affected, 'for we are all liable to error — and I myself am much more to blame than you, for I ought to have exerted my natural authority to prevent the evils to which your innocence, and inexperience have exposed you"' (Rush 170). Here, Mrs. Hammond appears to take selfless maternal responsibility for her daughter's flaws and thereby display for readers the possibility that she has engendered the virtuous values of republican motherhood all along. However, readers, like Emily herself, will eventually find out how horribly wrong they are.

Therefore, Kelroy manages to exhibit both the terrors of unchecked maternal power and of complete submission to that power. However, as much as it may overtly illustrate these horrors, Kelroy also shows readers the possibility of such actual female agency existing in the world. Because readers of these types of novels in late eighteenth- and early-nineteenth-century American literature were expected to be primarily the young women to whom they were often directly addressed, Mrs. Hammond's behavior does not constitute a directly threatening model of positive female selfhood and agency for them to imagine imitating. Instead, readers would have 
characteristically identified with young Emily Hammond, whose lack of voice and direct agency becomes complicit with her mother's actions in determining the tragic outcome of this novel. Furthermore, in reversing or resisting previous models for successfully navigating adolescence that were didactically asserted in novels of seduction, we can read Kelroy now as existing in a transitional mode that points the way to future texts wherein patriarchal authority itself may begin to be safely subverted.

\section{The Horrible Absence of Religion}

As we have seen, Emily's voicelessness in Kelroy often functions as a means of both resisting and submitting to oppressive authority. Similarly, in earlier novels of seduction, such as Charlotte Temple and The Coquette, religious discourse frequently worked in conjunction with narratorial didacticism either to reinscribe female behavior within acceptable norms or to condemn it outright while it still assisted in creating an imaginative space wherein female readers could imagine behaving differently. Female protagonists and female readers of these works may not have been consciously aware of this, but religious discourse itself was inextricably bound up in the rhetoric of these novels nonetheless. In exploring a variety of ways in which Kelroy functions against the stereotypical norms and modes of novels of seduction, we can see that religious discourse also operates along these same lines in the novel. The failure of religious discourse to stand as a moral authority in most of the novel demonstrates the terrors of a world in which rampant agency remains unchecked by its presence.

In the era of republican motherhood, which thrived immediately after the Revolution and into the early decades of independence, religion in America was undergoing a period of substantial change and growth. Although only so named in hindsight, this period of intense 
religious development has often been called the Second Great Awakening. ${ }^{8}$ Church membership in all denominations grew exponentially between 1789 and 1830, the years most typically associated with the Second Great Awakening. During this same time period, members of Rebecca Rush's own family, most notably her father Jacob Rush and her uncle Benjamin Rush, were contributing, in both political and religious public discourse, to the growth and development of the new republic. In Philadelphia, Benjamin Rush took the revivalistic energy of the Second Great Awakening and publically gave it a political turn, as previously noted. Having grown up in a prominent republican family that was clearly concerned with the future of the new nation and that valued Christian religious ideals, and having lived most of her life in Philadelphia, which was home to one of the most diverse combinations of church membership in the country (including Quakers, Baptists, and Presbyterians in great numbers alongside some Congregationalists and even Catholics ${ }^{9}$ ), it is hard to imagine that Rebecca Rush herself would have been ignorant of a republican ideology that infused political virtue with religious values. Yet, Kelroy itself, the only known piece of writing from Rebecca Rush, is horribly silent in terms

\footnotetext{
${ }^{8}$ Mark A. Noll loosely defines the Second Great Awakening as: "an imprecise term that is usually taken to refer to a series of revivals managed by Presbyterians and Congregationalists... that brought great numbers into the American churches"; he contends that if the term "Second Great Awakening" is used at all, "it should feature the less publicized efforts of Methodists and Baptists who did most of the work in churching and civilizing the American populace between the War for Independence and the Civil War" (567). Following what Noll describes as a "period of institutional and ideological confusion connected with the traumatic upheavals of the Revolutionary War," he explains that "a second stage, marked by popular and institutional advance on many fronts, began in the 1780s and 1790s. This era witnessed extensive and innovative mobilization - among the denominations, in bursts of revivalistic energy, and with the formation of voluntary societies"; furthermore, "the major colonial [religious] traditions all took steps to reconstruct themselves as American denominations" (179).

${ }^{9}$ According to Jon Butler, "In both New England and the Delaware Valley around Philadelphia, Dissenters established disciplinary institutions to strengthen their denominational organization...Dissenting denominations established the disciplinary institutions that characterized American Christianity for three centuries" and "it was the Delaware Valley that became the citadel of denominational authority in prerevolutionary America" (116-8). The dissenting denominations to which Butler refers included "Quakers, Baptists, and Presbyterians." In postrevolutionary Philadelphia, these denominations remained in place and, "propelled by a republican ideology to secure Christian foundations of American political virtue, and seeing in independence new opportunities to win adherents, religious leaders rushed to proselytize citizens in a growing nation" (274).
} 
of the type of religious discourse that permeated such works as Charlotte Temple and The

\section{Coquette.}

For most of the novel, Kelroy lacks, almost entirely, any reference to church, divine goodness, or providence, and in the few instances where such references are made they are either casual or mocking. For example, of Mrs. Cathcart, Mrs. Hammond's equal in shallow and superficial values, readers are told that "She made visits, gave parties, went to church, and to the theatre...not because she believed it to be either right or wrong, but because she saw others do so" (Rush 8). Other than this one mere mention of "church" near the start of the novel, several chapters pass before any religious reference is made again. Next, Charles Cathcart, her son, comments at a party that "'It is neither riches nor honours, nor the smiles of the world which can afford us perfect enjoyment; for moralists tell us, and our own experience hourly confirms the truth of the assertion that happiness is not attainable in this life"" (Rush 30). Charles is roundly mocked for this statement with such comments from others as, “'Bless us! Mr. Cathcart!' cried the bachelor interrupting him, 'are you going to preach?"' This response shows that most of the people in attendance would have only expected such religious references to be made in church, by a preacher, rather than during conversation at a party, and this separation of religious discourse from everyday life is one that continues to haunt Kelroy. Indeed, this very separation can be seen as one of the horrors of this novel.

More than half of the novel passes before any further reference to anything remotely religious is made. Even when the fire destroys their house and they nearly lose their lives, neither Emily nor her mother call on God to help them in this time of trouble or to thank kind providence for sparing their lives as characters might have been expected to do in traditional novels of seduction. Mrs. Hammond's utter lack of religious virtue as Emily's mother is further 
underscored when she is contrasted with Kelroy's mother, "whose simple garb, mild, religious eye, and peaceful countenance, presented an image of evangelical purity and resignation in strict unison with the chastened feelings, and benevolent principles for which she was so eminently distinguished"; immediately after this description, when Kelroy struggles with his decision to leave for India, his mother counsels him to "trust to a wise, and all seeing providence" (125). Mrs. Kelroy is the only mother in the novel who seems to have a proper respect for both religious and worldly authority and who also seems to have the potential to embody the virtues of republican motherhood in that she has raised a good son, but her presence in the plot is far too brief to be of any real influence on either Emily or the reader. Never is Mrs. Hammond presented as "benevolent" or as having "evangelical purity" and never does she seek to submit herself or her daughter to "a wise, all seeing providence."

Mrs. Hammond's fatal flaw may not so much be her selfishness, then, as it is her insistence on self-reliance at all costs. Just a few pages before this first description of Mrs. Kelroy is the account of the night of the fire that consumed the Hammond's home. Mrs. Hammond awakens to the realization that "the house must be on fire"; she throws open a window and shouts to a watchman on the street in order to summon help and is rescued shortly thereafter: "her strength and fortitude lasted until she reached the ground, and then she fainted" (Rush 121). Emily, on the other hand, is awakened by her mother's shrieks, but "not being endowed with as much self-command as her mother, she had nearly fallen a victim to her fears, and was found by Kelroy, who with frantic affection persisted to risk his own life in search of her, stretched motionless on the floor... and so enveloped in smoke and fire, that although she was still unscorched, he dared not entertain a hope of her revival, and carried her down the ladder, gone as he thought, forever" (Rush 121). Neither during the time when he fears for her 
life nor afterwards when she is revived does Kelroy call on God in any way to pray for Emily or to give thanks for her survival, so perhaps his mother was not as successful in instilling Christian values as readers may have initially hoped.

All parties are guilty, then, of a lack of reliance on God not only in their everyday lives but also in their most trying of times; Emily, however, in lacking the "self-command" to save herself from the fire as her mother had, and in physically submitting herself to Kelroy as her rescuer, may have been showing some potential to develop the kind of virtuous deference required of good republican mothers. She recovers very quickly from her injuries, but Mrs. Hammond's convalescence is much longer and seems to have broken her will, both physically and mentally. Mrs. Kelroy, on the other hand, who has also undergone tragedy in the form of her husband gambling away most of their money and his subsequent death which leads to her own relative indigence, maintains an accepting and virtuous attitude towards the will of "a wise, and all seeing providence"; her submissive attitude, even in the face of her husband's vices, does not reflect the ideals of republican motherhood that afforded women more agency than this in terms of their influence on their husbands. When Kelroy asks her if she thinks he should remain in America, "she with her customary disinterested virtue sacrificed her powerful wishes for him to remain" and instead advised him to trust in God to guide him (Rush 125). Ironically, if she had not "sacrificed" in this way, Kelroy would have stayed in America and many of the subsequent tragedies of the novel would have been avoided.

Mrs. Hammond stands in stark contrast to this virtuous image of the submissiveness seen when Mrs. Kelroy refuses to express any sort of bitterness over her husband's mismanagement of their money or to ask her son to stay in America with her as she herself wishes he could. Only after Mrs. Hammond wins the lottery, and thus is truly self-reliant in terms of money, does she 
make any reference to God or providence. Now that she is secure financially, readers are told that Mrs. Hammond "deceived [all] by her specious manner, and fine moral reflections on the wisdom and equity of providence in dispensing both good and evil; of which she professed to consider herself a striking example" (Rush 130). Never, though, do readers actually witness Mrs. Hammond using religious discourse directly; they are simply told that she does, in this one instance only, by the third-person voice of the narrator. Indeed, other than a small aside in the plot in which a buffoon-like character mocks the notion of going to church at all, no reference to religion, God, or providence is made again until the scene where Emily learns of Kelroy's supposed betrayal.

If nearly dying in a fire did not inspire Emily Hammond to call on God, it is hard to imagine what could cause her to do so, but, for a figure like Emily, perhaps the only fate worse than death is losing the one true love of her life. In the past, as we have seen, Emily has been unable to seek seclusion or silence directly to escape the demands of her mother or Kelroy, but instead she has fallen back on illness and aphasia as the means of asserting any type of self control in order to resist submitting to those oppressive powers. The loss of Kelroy, however, seems to have worked ironically to embolden Emily; it is almost as if removing the potential to defer to his wishes has also taken away her need to defer to anyone else, namely her mother. For the first time in the novel, Emily expresses her own wishes directly to her mother during the scene in which she excoriates herself for not listening to her mother's advice regarding Kelroy: "Emily said, 'Suffer me, my dear mother, to spend this day alone — and to be seen by nobodynot even yourself until to-morrow - and you will find I hope that I shall have made a proper use of the indulgence"' (Rush 170). Even though Mrs. Hammond has won the battle against Kelroy, she does not wish to allow Emily even this small repose from her control as she replies, “"My 
child, I would willingly permit you to do so, did I not fear it might be injurious to you!"' (Rush 170). Emily's response is the first time in which she directly uses any type of religious discourse: “'Oh no! no!' replied Emily; 'I can neither talk, nor listen, nor receive consolation, except from heaven and my own heart, and it would be most gratifying if my wish could be complied with"” (Rush 170-1). Their direct discourse ends here, but readers are told that Mrs. Hammond "expostulated with her for several minutes" before finally agreeing to leave Emily alone with "'heaven"” and her "'own heart."

The loss of Kelroy has a strange effect on Emily; unlike Charlotte Temple or Eliza Wharton, who each suffered unto death the loss of their beloved, Emily seems oddly resigned and strengthened by the experience: "Left to herself as she had desired, Emily spent her time not in weak and fruitless lamentation, but in reviewing her past conduct, and forming resolutions for the future (Rush 171). When Emily decides to emerge from her room the next day, she seems wiser and more confident. Indeed, she tells her mother, "'You were so kind as to comply with my request yesterday, let me not find you less so now — and-henceforward let us speak of him no more.--I feel that the lessons which I ought to teach myself will be best learned in silence"" (Rush 173). In first calling on "heaven" to offer her "consolation," and then following her selfactuated seclusion and silence with an even more direct request that she be left " in silence"" to teach herself lessons, Emily may be exhibiting her first signs of true self control and agency in the novel. Unlike her novelistic predecessors whose calls to heaven served only as a last attempt at salvation in the face of certain death, Emily's willingness to apply to heaven for consolation and then acknowledge her own faults in silence has allowed her to, as she says, "have acquired more self-knowledge than during the whole of my previous life; and it has enabled me to form resolutions, which if adhered to, cannot fail of restoring me to tranquility" (Rush 173). 
Her resignation in accepting what has befallen her but also in seeking to learn "lessons" from heaven about the experience is not only antithetical to the usual state of mind of female protagonists when learning of their suitor's duplicity, but it also prefigures a time in the novelistic development of female selfhood and agency when such protagonists will not need to suffer death for their sins, particularly when they show themselves to be willing to submit to heaven as Emily did. Indeed, the fact that Emily is not pregnant and has not eloped on a promise of marriage certainly harkens to this possibility; even her jilted engagement need not be a barrier to her future happiness as, as Mrs. Hammond notes, “owing to her [Mrs. Hammond's] own prudence, one of the most unpleasant consequences usually attendant on affairs of this nature, would be obviated by the circumstance of the engagement being still a secret to all except Helen Cathcart and her brother" (Rush 173).

Had the story of Kelroy ended at this point, it would still have been possible for it to have rectified all of the aforementioned gothic terrors of Kelroy and Emily's struggle against a mother who is the horrible embodiment of republican motherhood gone awry. Indeed, the plot itself seems to point to this possibility. Emily's newfound, courageous resignation that "it would be an unpardonable weakness to suffer her happiness to be destroyed by the remembrance of one who had proved himself worthy only of her scorn" (Rush 172) expands to the point where it earns her her mother's respect: "The fortitude with which Emily continued to bear what had befallen her, not only reinstated her in the good graces of Mrs. Hammond, but obtained for her from that lady a degree of respect, and consideration" (Rush 174). So, "when her own daughter exhibited such indubitable proofs of strength of mind so properly exerted, she [Mrs. Hammond] discovered her approbation of it in many instances" (Rush 175). Mrs. Hammond seems to have backed away from the idea of marrying Emily to a different affluent suitor and has instead, in the face of her 
own wealth and Emily's new strength, allowed her to choose to stay in the country in solitude rather than travelling or going to the city where she may have rejoined fashionable society and reentered the marriage market.

This time of peaceful solitude and hope for the novel not to end in tragedy is broken, however, by another of Mrs. Hammond's schemes: the arrival of (false) gossip from one of Mrs. Hammond's friends (the same Mr. Marney whom readers will later find out helped to forge the fake letters between Kelroy and Emily) that Kelroy will soon be in Philadelphia again, having “"been detained in Calcutta by an attachment for a pretty English woman there, who, it is said, has jilted him at last"” (Rush 179). Mrs. Hammond seizes on this opening as a means of manipulating and coercing Emily into marrying Dunlevy, who has never ceased to love her, but she does so in a way that seems to maintain her image of motherly concern and affection for both Emily and the reader. Emily overhears the news of Kelroy's impending return and "the complexion of Emily during this conversation changed to a death-like hue"; she retreats to the garden, but her mother follows her in hopes of taking advantage of Emily's weakened state and thus convincing her to marry Dunlevy (Rush 179). Emily resists and tells her mother that she has “"examined my own heart, where I find there is still much to be subdued before I can appear as I would wish"”; her mother replies, "Then take the advice of your mother, who knows you better than you know yourself; and, instead of wasting your soul and spirits in conflicts like these, make a more effectual effort, and by accepting a worthy amiable man who adores you, convince that reptile Kelroy, that you are not at his disposal...he will think you so if he finds you still single"” (Rush 181).

Emily does not wish to marry Dunlevy, who is actually a kind person and a worthy citizen, unless she can do so with a true heart, but her resolution is tragically weakened by a 
"dread of being again misled by adhering to her own judgment," and, when her best friend Helen begins advocating for the marriage "with well meant earnestness...to convince her that such a step was best calculated to restore to her that tranquility, which she now more than once despondingly declared was gone for ever," Emily’s determination crumbles (Rush 181). Emily eventually relents and agrees to be Dunlevy's wife. Ironically, Emily and Dunlevy seem wellsuited in every possible way that could fulfill the republican ideal of "affectional" and "voluntaristic" marriage. Indeed, she had previously told Helen that "Of all the lovers she had ever had, except Kelroy, Dunlevy was most agreeable to her” (Rush 177); also, readers are informed that, in addition to his already-sizable wealth, Dunlevy's uncle, "charmed to see him united to a lady of such singular beauty and merit, settled upon him two thirds of his large annual income" (Rush 182).

At this moment, when ostensibly the novel could have ended with all parties in happy states, save the disgraced Kelroy, and when all of the apparent evil horrors of this seemingly gothic tale have been resolved, Emily begins to pray, and that act is directly stated in the text of the novel rather than only being referenced indirectly. Readers are told that ...could wealth and splendour have purchased happiness, Emily would have found herself on the high road to felicity. But although the frequent exertions which she was obliged, perforce to make, had taught her the art of dissipating in a degree her gloomy reflections, and prevented her from being absolutely miserable, the restraint which it was necessary to impose upon herself, produced a torpor which rendered every scene alike tasteless and insipid; and whilst she was extolled, and admired as an object of envy to half her sex, her prayers were daily offered up to heaven for the restoration of her departed peace. (Rush 182) 
In the very next paragraph, immediately after the confession that Emily must offer up daily prayers to heaven "for the restoration of her departed peace," and without any ensuing time in which readers might imagine a happy outcome, Emily's mother suffers “a stroke of the palsy, which deprived her of her speech, and the use of her right side" and quickly dies (Rush 182). Had Mrs. Hammond truly been a model of virtuous republican motherhood, this turn of events might have seemed like a whim of cruel fate in taking her from the world just when she was "happy in the full attainment of her wishes"; indeed, Mrs. Hammond is "sincerely mourned by Emily, to whom her considerate kindness in the season of her affliction had endeared her beyond example.” However, in hindsight, readers may wonder whether Emily's prayers for “her departed peace" had truly been answered by the death of one whose most cruel manipulations had yet to be revealed. In the aftermath of losing her mother, Emily becomes "sensible to the value of her husband, whose tenderness prevented her from knowing a wish or want which he had power to remedy; and as time softened her grief, gratitude seemed to inspire her with something like affection for him" (Rush 182). In other words, again ironically, in the death of her mother, Emily's prayers for peace do indeed seem to be answered.

Once more, had the story ended here its tragic and gothic threats would never have been fully realized and readers may have left the novel believing in the necessity of submitting to maternal authority in order to ensure their own future happiness. However, readers are not given a chance to savor this moment because they are told, within the same paragraph in which Emily admits to some measure of affection for her husband, that "an accidental discovery revived at once the flames of her smothered passion, and fixed her fate for ever"; her mother's schemes come to fruition even after her death (Rush 182). The "accidental discovery" comes about when Emily looks in a desk for "some papers necessary to the settlement of the estate" of her mother 
and inadvertently discovers "a small unknown drawer in a recess of her mother's writing desk" (Rush 183). In the drawer, Emily finds the letter Kelroy had written to her breaking off their engagement printed out in her mother's own hand, along with evidence that Mrs. Hammond's accomplice was Mr. Marney, who had a talent for forgery. Emily reads letters that she had never received that contain evidence of "his then unchanged [emphasis Rush's] affection"; upon hearing her husband's voice, she returns the letters to their hiding place and, "when Dunlevy entered the chamber, he found her lying senseless on the floor" (Rush 184). Emily does not recover from "the death-like swoon into which...[she] had fallen...[it] was succeeded by a fever which reduced her to the borders of the grave, and she recovered from it only to experience the pangs of a lingering decay" (Rush 189). Here again, ironically, traditional religious discourse is finally called upon, this time by Emily's friends as they encourage her "to look with hope, and confidence toward futurity" based on "the innocence of her past life" (Rush 190). In other words, they believe that Emily has every hope of heaven because she has led a virtuous life.

Such a hope is little consolation to Emily. She has been "betrayed where she had believed herself cherished-sacrificed to the inhuman machinations of her own mother, who whilst employed in forging the chains of her wretchedness had appeared to be actuated by the warmest, and most disinterested wishes for her welfare" (Rush 189). The tragic and gothic potentials of this novel are thus realized, and the treachery is doubly cruel in that it comes in the figure of her mother, the one who is supposed to embody the most selfless, "warmest, and most disinterested wishes for her welfare." Despite moments that highlighted her own latent potential for acceptable agency, Emily suffers the same fate as her novelistic predecessors: she dies shortly after she "had attained her twentieth year, [and] all that remained of the once gay and fascinating Emily Hammond was consigned to the bosom of the earth" (Rush 191). 
The final pages of the novel only serve to draw out readers' suffering as they experience the one last lamentable horror of this tale. Before she dies, Emily, without telling her what the papers contained, begs Helen Cathcart to take the concealed evidence of her mother's machinations and keep it safe until such a time as she saw Kelroy again, so that "he may know I was not the faithless, heartless being he supposed me."' As further evidence of her final goodness even in the face of her impending death, Emily tells Helen that "“I have been injured, but have forgiven those who destroyed me...I am actuated not by a spirit of unchristian resentment, but by a natural wish to stand acquitted in the eyes of one with whom I once hoped to have been happy"' (Rush 190). This last use of religious discourse might have indicated some hope for Emily to be redeemed eventually in her true love's eyes. Such an ending, wherein Kelroy would come to know that Emily was faithful, while still tragic could have had some redemptive power to show readers that true love can be vindicated in the end. However, rather than comforting Kelroy, the news of her constancy destroys him and completes the tragedy: "But the tortures he had sustained from his once-suppressed and now-awakened sensibilities unhinged him for ever; and his approaches towards insanity grew so evident, that Helen...felt infinitely relieved when informed that he meant to take a voyage to Leghorn” (Rush 194). If Kelroy's insanity were not enough of a picture of torture on which to end this tale, the last sentence of the novel states, "Three weeks after, the vessel in which he had embarked, perished, together with all on board of her, in a storm; and Kelroy and his sorrows were hushed to rest in the depths of the ocean" (Rush 194). As far as readers know, no promise of heaven or comforts of forgiveness were given to poor Kelroy in his final days. The ending suggests that Charles Cathcart's early declaration, that earthly happiness is not possible, was true for all of these characters and their readers: "“It is neither riches nor honours, nor the smiles of the world which can afford us perfect 
enjoyment; for moralists tell us, and our own experience hourly confirms the truth of the assertion that happiness is not attainable in this life"” (Rush 30).

\section{Conclusions}

As we have seen, Kelroy rarely functions according to the conventions of typical seduction novels; instead, it reverses or negates those conventions and offers readers a young woman who reacts to her circumstances in life in ways completely antithetical to those of her novelistic predecessors. Unlike Charlotte Temple or Eliza Wharton, Emily seldom challenges parental authority, and her reliance on religious discourse as a moral authority is spotty at best. Even more thought-provoking is the novel's insistence on an ending unnecessarily fraught with tragedy and ruin for almost every main character. Dana D. Nelson's Introduction to the novel implies that the War of 1812 overshadowed the publication of Kelroy to such an extent that it "received virtually no critical notice" (xv). Even if the literary marketplace had been functioning, however, the book was too challenging, given its unusual status as neither a narrative of seduction nor yet a tale of domesticity, to imagine it enjoying much popular success. Its existence harkens back to a time in American literary history when women writers and women readers rarely found model characters whose quests for self-actualization did not necessitate their own destruction. As such an attempt, Kelroy effectively destroys the stereotypes upon which such novels as Charlotte Temple and The Coquette depended even as it depicts the new model of virtuous republican motherhood as inherently fraught with potential for abuses if it is not employed within a deferential environment stabilized by an emerging discourse of universal salvation. That is the true horror of this story, then — that it ultimately offers no viable model for female behavior to its readers. In neither allowing them to identify against the 
young, female character nor yet fully identify with her, Kelroy offers only despair. That utter hopelessness may have been why critics failed to acknowledge it. Nevertheless, in destroying previously accepted models for behavior, Kelroy begins to make clear the path for subsequent novels to embark on the journey of finding new ones. 


\section{Chapter Four: \\ Universal Salvation and Emerging Agency in A New-England Tale}

\section{Introduction}

Originally intended as only a brief religious tract, Catharine Maria Sedgwick's first novel, A New-England Tale (1822), brings to life the shifting religious culture of her New England community and thereby becomes a vehicle for her personal and political beliefs about the role of religion in people's everyday lives. While critics such as Linda Kerber and Barbara Welter, amongst many others, have contended that the ideologies of republican motherhood and true womanhood were what motivated the emerging female voices of novelistic discourse in nineteenth-century America, Sedgwick's writing in A New-England Tale offers a unique perspective on those ideologies by grounding them in religious discourse. ${ }^{1}$ As Kerber has explained in her writing on republican motherhood, women in this time were expected to defer to men in order to maintain the political and patriarchal hierarchy upon which our nation's growth and stability depended, but they were not necessarily supposed to be entirely passive in those deferrals. $^{2}$ In the novelistic, post-revolutionary world of Charlotte Temple and Eliza Wharton, passivity was depicted as a female virtue necessary to reinforce the patriarchal nation-building of that era. In the era of republican motherhood, however, women, and mothers in particular, were expected to model behavior for their children that would encourage them to grow into productive

\footnotetext{
${ }^{1}$ In particular, see also Jane Tompkins' Sensational Designs: The Cultural Work of American Fiction 1790-1860, Nancy F. Cott's The Bonds of Womanhood: “Woman's Sphere” in New England, 1780-1835, and Carroll SmithRosenberg's Disorderly Conduct: Visions of Gender in Victorian America.

${ }^{2}$ See Chapter Three of this dissertation. Kerber compares the deferral of a republican mother to that of an ordinary citizen who defers his right to govern directly by electing officials to do so for him. In that analogy, the citizen would still maintain his own ability to make decisions and to run his day-to-day life; that citizen would also retain his ability to voice his own opinion should the officials he elected veer dramatically off course from what could be perceived as the correct path for the nation. In other words, the citizen of the new nation is not like a subject in a monarchy who must submit passively to his sovereign's will. Similarly, then, republican mothers could not be as passive as their eighteenth-century counterparts because their responsibilities in the home had actually increased and taken on more significance as men left that home and went out to make their way in the world, as Barbara Welter has demonstrated.
} 
citizens of the new republic. A New-England Tale takes up these concepts of passivity and deferral but, rather than limiting them to the realm of social, gender, or political roles, Sedgwick maps them onto her own beliefs about Calvinism versus other increasingly popular denominations that offered sinners some agency in their own salvation.

Over the course of the novel, Sedgwick clearly contends that Calvinism is no longer a viable dogma because it requires the utter passivity of its adherents. She argues that the doctrine of selective election purported by Calvinists, in which the sinner has no ability to act to seek out his or her own salvation, is harmful and counterproductive both to individuals and to society at large in the new republic. ${ }^{3}$ Instead, she advocates the adoption of one of the various newer sects that embraced universal salvation, such as Methodism, Unitarianism, and Quakerism, in which the adherent makes a daily choice to act morally and to choose to accept God's saving grace. While this approach to sin and salvation still requires the penitent to defer to the will of an omniscient and omnipotent God who alone could offer salvation, it nevertheless requires an act of agency on the part of the sinner to choose to accept that saving grace and to strive to be worthy of it in the daily acts of a virtuous life. Sedgwick seeks to depict for her readers the horrific consequences of embracing a religious ideology in which followers have no true agency in their own salvation; in so doing, she brings to light the importance of agency and free will for all people, and in particular women, to lead happy and successful lives.

A New-England Tale eventually developed into one of the earliest examples of what Nina Baym termed "woman's fiction" to exhibit many of the characteristics of what would become the wildly popular, often-formulaic domestic novel by the mid-nineteenth century. As such, it stands as a kind of proto-domestic novel, one that we can see today as bridging the gap in sentimental,

\footnotetext{
${ }^{3}$ For more particulars on Calvinist doctrine, see "Part I: Calvinist Origins" of E. Brooks Holifield's work or Mark A. Noll's "The Doctrines at Stake" on pages 265-268 of his book. Also, for more on American Calvinism, see Noll's chapter in that same work, "The Americanization of Calvinism."
} 
novelistic discourse between Rebecca Rush's Kelroy (1812) and Susan Warner's runaway bestseller, The Wide, Wide World (1850). Whereas Kelroy, as I contended in my previous discussion of that novel, broke down but never attempted to rebuild many of the stereotypical characteristics of earlier novels of seduction, A New-England Tale reforms several of those commonalities into the themes and tropes that would come to dominate novels of domesticity in the decades that followed it. Furthermore, the typical sources of moral authority that held sway in previous women's novels, namely parental figures and religious discourse, are challenged, disassembled, and then rebuilt in concert with Jane Elton's journey of self discovery in this story. Finally, A New-England Tale sets aside the classic figure of the young, female protagonist who is tempted by seduction or romance, and ultimately destroyed by it, and reverses that norm by offering its female readers a heroine with whom they may identify without fear of imaginary or psychological self destruction or abnegation. Over the course of the novel, the distinction between passivity and deference becomes integral to understanding how this shift from tales of seduction to domestic ones in sentimental novelistic discourse occurred. That distinction is tied to Sedgwick's contention that the free-will doctrines of certain religious denominations offered both women and men a necessary alternative to Calvinism in a nation that so valued individual agency as one of its governing principles. While much of this novel still reifies patriarchal authority and affectional marriage as the ultimate sources of female happiness, ironically suggesting that only in submitting to such conventions can women find their own true path in life, it nevertheless also offers to its readers several examples of positive female behavior, self identity, and agency through which they may begin to imagine themselves making similar choices in their own lives. Therefore, although we have been traditionally accustomed to thinking of similar plot lines as driven by the philosophy of republican motherhood, $A \mathrm{New}$ - 
England Tale suggests that the potential for female agency may have had its genesis in the religious questions of free will and salvation that were at stake for all people in New England in the first half of the nineteenth century.

\section{II. "It is my duty to subdue, not rouse my spirit" -A New-England Tale's Transformation of Genre Conventions}

A New-England Tale picks up in many ways where Kelroy left off by reversing or reissuing some of the stereotypical conventions of previous seduction novels in order to challenge those norms and thereby offer its female protagonist new ways of navigating her world and its female readers a new perspective on them. It begins in much the same way as Kelroy did, by reversing the stereotype of the morally upstanding father depicted in most seduction narratives and instead offering a father who is described in the first paragraph of the story as a "purse-proud man" who "was careful to appear quite as rich as he was" (Sedgwick 5). Like Emily Hammond's father, Mr. Elton's wealth had been acquired 'rather owing to accidental circumstance, than to his skill or prudence; but his vanity appropriated to himself all the merit of it"; high living and further speculation cause him to incur "losses...more rapid than his acquisitions had been" (Sedgwick 6). Here, then, we see another example of a paternal figure who fails to live up to his familial duty and provide a secure home and virtuous example for his wife and child. Gone, now, are the model father figures of Charlotte Temple or Eliza Wharton who sought only the best path in life for themselves and their daughters; in their stead we find their moral opposites - precariously wealthy men who value outward appearances over inner decency and who disregard all other needs save their own. And, much like Mr. Hammond's passing, the death of the father of the female protagonist precedes the events of the novel: "Mr. Elton, after his pecuniary embarrassments were beyond the hope of extrication, maintained by 
stratagem the appearance of prosperity for some months, when a violent fever ended his struggle with the tide of fortune" (Sedgwick 8). Unlike Kelroy, however, A New-England Tale's initial mother figure is not the father's equal in those sins.

The figure of Mrs. Elton, so different from that of Mrs. Hammond in Kelroy, is more in line with those ineffective or merely passive wives and mothers of Charlotte Temple and The Coquette who, despite their inability to affect the choices and behaviors of their daughters, were nevertheless depicted as moral and admirable women; she is most similar, then, to Mrs. Kelroy whose virtue was portrayed as entirely passive and ineffective at preventing her husband's losses. Mrs. Elton is first described as a wife who "neither deserved nor shared the dislike her husband received in full measure. On the contrary, she had the good-will of her neighbours"; moreover, "the gentleness and humility of her manners, and the uniform benevolence of her conduct, averted the censure that would otherwise have fallen on her" (Sedgwick 5-6). Like Mrs. Temple and Mrs. Wharton, she submits herself completely to her husband's will and desires; unlike those women who had model husbands, however, Mrs. Elton submits to her husband even when she "perceived he was gradually sinking into a vice, which, while it lulls the sense of misery, annihilates the capacity of escaping from it — and yet she silently, and without an effort, acquiesced in his faults" (Sedgwick 6). A New-England Tale sets up, then, a unique world wherein the expectations for the behavior of the father figure are reversed from their previous conventions but the ones for the mother are at first maintained.

Mrs. Elton is portrayed as weak and not in command of herself, her home, or her child: “... she acquiesced silently and patiently in her unhappy fate...”; and, "She could not oppose a strong current. She had not energy to avert an evil, though she would have borne any that could have been laid on her, patiently"; and, most incriminatory of all, "To her child, she performed 
her duties wisely, and with an anxious zeal; the result, in part, of uncommon maternal tenderness, and, in part, of a painful consciousness of the faults of her own character; and, perhaps, of a secret feeling she had left much undone that she ought to do" (Sedgwick 6-7). Indeed, her passivity extends even unto life itself after the death of her husband: "His wife was left quite destitute with her child...A more energetic mind than Mrs. Elton's might have been discouraged at the troubles which were now set before her in all their extent...she, irresolute, spiritless, and despondent, sunk under them" (Sedgwick 8). When a mother with all of the passive characteristics of those typically found in novels of seduction is confronted with the prospect of a life in which her husband has died and left her and her daughter penniless, there are very few narratorial options open to her. ${ }^{4}$ Mrs. Elton "had, from nature, a slender constitution; her health declined, and, after lingering for some months, she died with resignation, but not without a heart-rending pang at the thought of leaving her child, poor, helpless, and friendless" (Sedgwick 8). So, A New-England Tale first reverses the expectations for the conventional father figure in a woman's novel, much as Kelroy did, but it also, unlike that novel, immediately shows readers the consequences of maintaining the level of passivity recommended as moral behavior for women by previous sentimental novels in the face of such male behavior.

In acquiescing to passivity, Mrs. Elton becomes the first of several of Sedgwick's characters to illustrate the dangers of accepting one of the fundamental tenants of Calvinism, namely that no person may effect his or her own salvation. According to traditional Calvinist belief, humans are innately depraved and no amount of good works will ensure their salvation; only God's grace will save His elect from eternal damnation. For Sedgwick, who had converted from Calvinism to Unitarianism shortly before writing A New-England Tale, the principle of

\footnotetext{
${ }^{4}$ Mr. Temple lives throughout the entirety of Charlotte Temple, but when Eliza Wharton's father dies her mother is looked after by her adult son. Mrs. Elton has no such male in her life.
} 
universal salvation espoused instead by the free-will doctrines of such churches as Unitarian, Methodist, or Quaker rightly afforded adherents the ability to choose to accept God's universally-offered grace by living a virtuous life. Sedgwick expanded the text of her original tract addressing such matters into a novel after being encouraged to do so by several of her brothers, who also helped her to publish it. ${ }^{5}$ Sedgwick was born in 1789 to a prominent Massachusetts political family (her father served the U.S. federal government as both a Congressman and a Senator in addition to serving as Chief Justice of the Massachusetts Supreme Court). Calvinism, in the form of Congregationalism, was the religious practice of both her community and her family. Following the Revolution, only Connecticut and Massachusetts, both strongholds of Calvinism, retained a form of theocracy; constitutional disestablishment did not occur in those states until 1818 and 1833 respectively. $^{6}$

The demands of Calvinism weighed heavily on the Sedgwick family and their community, as it did on many of citizens of that era; as Susan K. Harris contends in her Introduction to A New-England Tale, “...the Sedgwick family history...demonstrates a cultural stress that was shared by men as well as women. As Calvinists, they were vulnerable to depressions and anxieties directly attributable to that religious sect's insistence that very few people, even those who spent their lives in good works, would escape the fires of damnation" (ix). Furthermore, Harris claims that "The psychological burden that Calvinism imposed was certainly one of Sedgwick's motives for joining the Unitarian Church as well as one of the motives for writing the religious tract that evolved into A New-England Tale" (x). Family letters from that time indicate that several of Sedgwick's brothers and her father had made the same

\footnotetext{
${ }^{5}$ No copies of this original tract have been found, but several sources support this story of the novel's beginnings, including Sedgwick's own letters and journal writings. For more information, see Harris's Introduction to the Penguin edition.

${ }^{6}$ See Chapters One and Two of this dissertation for more on the time of disestablishment. Also see pages 267-8 of Jon Butler's work for more information.
} 
conversion in the decade preceding the publication of $A$ New-England Tale in 1822.

Nevertheless, her sisters were slower to distance themselves from their Congregational heritage, and her mother died in 1807 before her father had made his conversion around 1813; it would still be two decades after that before Massachusetts would disestablish religion officially in its constitution.

Sedgwick lost her mother, Pamela Dwight Sedgwick, in 1807 after she had endured several bouts with infirmity and mental illness. In Sedgwick's autobiography, titled by its recent editor, Mary Kelley, as The Power of Her Sympathy, Sedgwick copied verbatim a letter from 1788 wherein her mother expressed, as Sedgwick called it, "her conjugal devotion, and selfnegation" when it came to her relationship with her husband and his desire for a life of political service: "Iff, on the whole, you think a public line of life will be most conducive to your interest and happiness, I will pray that He alone who is the author of all good will strew peace in all your paths. Submission is my duty, and, however hard, I will try to practice what reason teaches me I am under obligation to do"'(58-9). This total submissiveness, so culturally ingrained in the post-Revolutionary notion of what it meant to be a good wife, was connected by Sedgwick to the precepts of Calvinism as well. As Sedgwick writes about her sister Eliza in her autobiography, whom she saw as being so like her mother: "She had her modesty, her self-diffidence, her humility. This was a constitutional quality, but so authorized and enforced by their religion that to them both it took the potent form of a duty" (63). Later in the autobiography, Sedgwick laments that Eliza, like her other sister Frances and their mother, "suffered from the horrors of Calvinism. She was so true, so practical, that she could not evade its realities; she believed its monstrous doctrines" (86). 
The shift in New England from Calvinist (mostly Congregational) denominational dominance to other forms of Protestantism that offered worshippers more agency in their own salvation paralleled the shift from establishment to disestablishment governments in that region. Daniel Walker Howe contends that "Ever since Constantine the Great had made Christianity the established religion of the Roman Empire, the Western world had typically connected church and state. Now, the Americans undertook to experiment with their separation: Religion would be purely voluntary." However, he continues, "Far from hindering religion, the American model of voluntarism hugely facilitated it, liberating powerful religious energies. Religion, which had played such an important part in the life of the American colonies, was reinvigorated and reawakened in the life of the American republic" (165). More importantly, these new, more democratic forms of religion offered members a local way of directly participating in the formation of their communities and in the cultural authority those institutions represented. And, unlike political institutions, these newly-formed religious ones extended such participation to all members: “...the religious institutions they created sometimes displayed more democracy than the nation's civic ones. Women, African Americans, and newly arrived poor immigrants were all participating in religion, often in leadership roles, before they participated in politics. The churches and other voluntary associations nurtured American democracy" (Howe 166).

In A New-England Tale, this shifting religious culture is epitomized as Sedgwick expresses her personal and political beliefs about the role of religious authority in people's everyday lives through specific characters' voices and actions. Oftentimes, those characters challenged, negated, or reversed the stereotypical roles found in previous novels of seduction. If Mrs. Elton, for example, had shown any moral strength at all in the face of her husband's behavior, perhaps their debt and both of their deaths could have been avoided. As the narrator 
tells readers, Mrs. Elton "had not energy to avert an evil, though she would have borne any that could have been laid on her, patiently. She knew her husband's affairs were embarrassed... she perceived he was gradually sinking into a vice... and yet she silently, and without an effort, acquiesced in his faults" (Sedgwick 6). Rather than choosing a path of direct action that may have offered her the possibility of a long and happy life, Mrs. Elton maintains the same level of passivity required by Calvinism and thus ensures her own destruction. The narratorial voice in $A$ New-England Tale assists readers in understanding the new philosophy of free will that Sedgwick wishes to emphasize. By demonstrating the fatal consequences of utter passivity for Mrs. Elton and by employing an occasionally active and communal narrator to comment on those events, A New-England Tale succeeds in reissuing the stereotypical role of both mothers and narrators for a new readership in a new era.

As we have seen, in earlier seduction narratives female passivity and obedience were valued and rewarded; indeed, such behavior was often commented on and recommended by the narratorial voices present in those tales. While Kelroy negated that expectation by removing almost entirely any type of exterior, evaluative voice, A New-England Tale reinstates a narrator who comments on events and occasionally offers readers guidance about how to interpret them in order to contextualize Sedgwick's warnings about Calvinism and passivity along with her contentions about the virtuous benefits of agency. Although this voice is often maintained in the third person, unlike the first person ones employed in Charlotte Temple and The Coquette, it nevertheless assists in shaping readers' perceptions in meaningful ways; in fact, at times that third-person distance is broken in order to emphasize a particularly significant point. When this happens, the narrator speaks using a communal "we" rather than an "I," implying that readers, along with the teller of this tale, are part of a larger community's response to events such as 
these. For example, when Mrs. Elton is first described, the narratorial voice comments parenthetically but significantly on that depiction: "She had that passiveness which, we believe, is exclusively a feminine virtue (if virtue it may be called)..."; later, on that same page, the narrator tells readers that "The morale, like the physique [emphases Sedgwick's], needs use and exercise to give it strength. Mrs. Elton's had never been thus invigorated" (Sedgwick 6). This narratorial voice helps to make the crucial moral distinction between passivity and deference that Sedgwick wishes to emphasize as proper.

In addition to reconfiguring the role of mothers and narrators, $A$ New-England Tale also transforms its primary romantic plot. Jane Elton's suitor for most of the novel is Edward Erskine, a handsome playboy whose character harkens back to such seducers as Montraville and Major Sanford. Like them, he is not so much evil as he is young and selfish; as the narrator tells readers, "he had not so nice a moral sense, as we hope they possess" (Sedgwick 76). Unlike the seducers of previous sentimental novels, however, Erskine's moral failures are not depicted as solely of his own making; in this era of republican values, his parents are described as the wellintentioned but misguided cause of many of his shortcomings: "His parents had lost several children in their infancy, and this boy alone remained to them- to become the sole object of their cares and fondness. He was naturally what is called 'good-hearted,' which we believe means kind and generous. Flattery, and unlimited indulgence made him vain, selfish, and indolent. These qualities were, however, somewhat modified by a frank and easy temper, and sheltered by an uncommonly handsome exterior" (Sedgwick 77). These characteristics are inflated following the death of his parents, which results in his inheritance of their "handsome estate" and his thus being rendered both more attractive as a marriage partner and more able to 
act selfishly with impunity. Distinct from the suitors in Charlotte Temple, The Coquette, or Kelroy, Erskine is not poor, and a lack of finances does not motivate his behavior.

Unlike his more destitute forebears, then, Edward Erskine's position as the potential romantic partner in this novel is not tied up with his financial status. While he does engage in some of their same reckless behavior, like gambling and speculation, Erskine's extremely generous inheritance ensures his financial stability regardless of his somewhat wild conduct. However, like Montraville and Sanford, he is caught between two young women, one poor and the other wealthy: Jane Elton and her well-off cousin Elvira Wilson (with whose family Jane has lived since her parents' deaths). In traditional seduction narratives, the impoverished seducer would be romantically attracted to the beautiful yet penurious young woman but would have the opportunity to marry a less-attractive yet wealthy one. Much like those tales, here poverty and beauty coincide in the figure of Jane Elton, but her financial state is neither the reason for Erskine's hesitation nor is her beauty the primary reason for his attraction. Instead, Erskine is caught between "Jane's virtues" and Elvira's "gayety of... spirits" (Sedgwick 76).

Jane Elton, from the beginning, is depicted as more akin to Emily Hammond than she is to either Charlotte Temple or Eliza Wharton: "Little Jane had nursed her mother with fidelity and tenderness, and performed services for her, that her years seemed hardly adequate to, with an efficiency and exactness that surprised all who were prepared to find her a delicately bred and indulged child" (Sedgwick 8). As she matures, she is shown to be obedient, hard-working, virtuous, modest, and kind; she acts with such humility that she rarely seeks any selfish indulgence or pleasure. Because she has been taken in by her Aunt Wilson (Elvira's mother and a wealthy widow) and has no means of her own, she strives to undertake any task given to her with a cheerful heart, despite being treated like a servant in her Aunt's home: "The very labour 
her aunt imposed on her was converted into a blessing, for it occupied her mind, and saved her from brooding on the happy past, or the unhappy present...Her dexterous hand was often put in requisition by her idle and slatternly cousins, and their favor was sometimes won by her kind offices. But more than all, and above all, as a source of contentment and cheerfulness...was Jane's unfailing habit of regulating her daily life by the sacred rules of our blessed Lord" (Sedgwick 42).

Accordingly, unlike Emily Hammond (or even Charlotte Temple or Eliza Wharton who really only call on God in times of desperation), Jane learns to rely on God as the way of "regulating her daily life"; at dawn, when no chores were yet required of her, Jane would "join her devotions to the choral praise. At this hour she studied the world of truth and life, and a holy beam of light fell from it on her path through the day" (Sedgwick 42). Because she possesses the virtues of Emily Hammond in combination with a daily reliance on God, readers may have hope from the beginning that her fate may be different than that of Emily's. Despite these merits, though, Jane's suitor is no virtuous Kelroy, so she also falls prey to some of the same potential traps as Charlotte Temple and Eliza Wharton did. In blending a more morally-aware protagonist with one who nevertheless enjoys the attentions of a handsome but reckless suitor as any female reader might, A New-England Tale is able to reissue this stereotype and thereby begin to change the expected outcome for such a story.

When Edward Erskine first shows a romantic interest in Jane, it is not because he has spied her from afar and been instantly struck by her beauty without knowing anything else about her, as was the case for Montraville, Sanford, and even Kelroy. Instead, Erskine has known Jane for many years, has lived in her same town, and has gone to school with her. He has even been to her home on several occasions because he has been flirting with her cousin, Elvira, for quite 
some time. At an annual school exhibition, Jane is called upon to read a composition before the entire assembly. Lest readers think this performance by a woman is immodest, they are told that only "young men and boys were to display those powers that were developing for the pulpit, and the bar, and the political harangue. The young ladies were with obvious and singular propriety excluded from any part in the exhibition, except that...the prize composition was to be read by the writer of it" (Sedgwick 55). Because the compositions were to be written on topics of "moral or religious character," women were thus allowed to speak publically, a situation that reinforces the pervasive republican notion in this novel that while women are to defer to men in most situations, they may nonetheless speak up on matters of morality. Initially, the curtain is drawn back to reveal Elvira Wilson, Jane's foil (and one who more truly resembles the likes of Charlotte or Eliza), as the honored writer of the prize composition. As she speaks, her "usually high colour was heightened by the pride of success and the pleasure of display. Some were heard to say, 'She is a beauty;' while others shook their heads, and observed, 'The young lady must have great talents to write such a piece, but she looked too bold to please them"' (Sedgwick 58). However, when Elvira's speech comes to an end, an old man in the crowd stands up and declares that he has read this essay several times on a scrap of an old newspaper he has tacked up to his wall. The teacher quickly investigates the man's claims by following him to his house just around the corner and returns to announce that the piece had "been copied, verbatim, from the original" which had been published in a Boston paper several years before. The teacher closes the curtain and seats a new student behind it to read the composition "which had been pronounced next best to Miss Wilson's; and which, he could assure the audience, was, unquestionably, original" (Sedgwick 59). 
When the curtain is drawn aside this time, Jane is revealed, and her appearance and demeanor are completely antithetical to Elvira's. Whereas Elvira was dressed in bright and gaudy clothing, Jane wears a "plain black silk frock"; while Elvira's hair was done up in braids and ringlets and adorned with "blue glass beads," Jane's was "parted on her forehead and put up in a handsome comb, around which one of her young friends had twisted an 'od'rous chaplet of sweet summer buds"' (Sedgwick 59). Most striking, however, was the difference in their bearing. Elvira had stood and, "instead of reading her piece, she spouted it with all the airs and graces of a sentimentalist of the beau monde" (Sedgwick 58); Jane, on the other hand, "advanced with so embarrassed an air" and seemed "reluctant to receive the honour that was forced upon her." She spoke in a "low and faltering voice, that certainly lent no grace, but the grace of modesty, to the composition." Nevertheless, her reading touched many in the audience, particularly when they considered the familial and financial situation of the speaker: "The subject was gratitude, and the remarks, made on the virtue, were such as could only come from one whose heart was warmed by its glow" (Sedgwick 59). After Jane returns to her seat, Erskine tells the companion sitting next to him, "“By Jove, it is the most elegant composition I ever heard from a girl. Jane Elton has certainly grown very handsome"” (Sedgwick 59).

This moment, when he hears Jane speak publically on the virtue of gratitude, is the point at which Erskine becomes romantically attracted to her. Despite her less showy appearance, he tells his friend, "I did prefer her cousin...but I never noticed Jane much before; she is but a child, and she has always looked so pale and so sad since the change in her family. You know I have no fancy for solemn looks." He considers Elvira's merits, on the other hand, and remarks, "Elvira is certainly handsome - very handsome; she is a cheating little devil; but for all that, she is gay, and spirited, and amusing. It is enough to make any body deceitful to live with such a 
stern, churlish woman, as Mrs. Wilson. The girl has infinite ingenuity in cheating her mother, and her pretty face covers a multitude of faults" (Sedgwick 59-60). This little speech by Erskine encapsulates the central reasons for his attraction to both cousins as it simultaneously describes his own moral deficits. Soon thereafter, he manages to catch up to Jane on one of her evening walks; he tells her, "It is almost too late to be abroad without a companion." She, who has often led a solitary existence since the death of her parents, tells him, "II am used...to be without a companion, and I do not need one." He replies, "'But I hope you do not object to one? It would be one of the miseries of human life, to see such a girl as Jane Elton walking alone, and not be permitted to join her." Jane seems confused by his attentions at first, so, as the narrator tells, "Jane felt kindness, though she knew not how to receive gallantry. She thanked him, and they walked on together" (Sedgwick 62). After this walk, Jane takes kindly to the attention Erskine begins to pay her and seems flattered that the most eligible bachelor in town has shown an interest in her. However, while he seems genuinely enamored with Jane, his selfish and impetuous nature also plays well with Elvira's fun-loving spirit; so, rather than being torn between the financial situation of his two love interests, as Montraville and Sanford were, Erskine seems to be undergoing a moral trial that may result in the salvation or damnation of his soul.

This situation subtly underlines for readers the notion that women are the true moral leaders in this time while also reinforcing the importance of agency in determining salvation. Instead of being led astray by her suitor's entreaties, as Charlotte and Eliza were, Jane struggles to guide Erskine towards her own more virtuous trajectory in life. For example, when Erskine drops by the Wilson household one evening, he says, "“I called, Mrs. Wilson, to ask of you the favour of Miss Elton's company to-morrow on the bridal escort."' Mrs. Wilson, who wishes to 
encourage her own daughter's aspirations to marry Erskine, replies in such a way as to seem to throw Jane into a bad light: “"I am sorry...that any young woman's manners, who is brought up in my house, should authorize a gentleman to believe she will, of course, ride with him if asked."” Erskine responds, "“I beg your pardon, madam...I have been so happy as to obtain Miss Elton's consent, subject to yours." Mrs. Wilson answers him quite sarcastically by saying that Jane must have known that tomorrow was "lecture-day" at her church and, "indifferent as she is to the privilege of going to meeting, she knows that no pleasures ever prevent my going"' (Sedgwick 79). Erskine rises from his chair and walks over to whisper to Jane, who stands at the window: "Rouse your spirit, for heaven's sake; do not submit to such tyranny"” (Sedgwick 80). Had A New-England Tale been merely a stereotypical seduction novel, Jane would not have risked losing Erskine's affections by going against him; likewise, as a novel that still upholds many conventional patriarchal and Christian values, Jane could have been expected to acquiesce to her suitor's desire and defy her aunt, especially given her aunt's debatable motives. The protagonists in seduction novels like Charlotte Temple and The Coquette similarly defied their female guardians to submit to the desires of their male seducers - Charlotte defied the headmistress of her school and Eliza defied the advice of several female friends, and eventually her own mother, to go out and meet their seducers. Emily Hammond, in Kelroy, though, does not ever need to disobey her mother or challenge Kelroy's desires because he never acts in a morally questionable way or asks Emily to do so. However, despite her aunt's dubious behavior, which is very similar to that of Emily Hammond's mother, Jane feels that she owes her aunt some measure of respect for taking her in after her own parents' deaths. As the narrator relates, after being encouraged by Erskine to act disrespectfully towards her aunt, "Jane had recovered her self-possession, and she replied, smiling, 'It is my duty to subdue, not rouse my spirit."' So, 
despite knowing full well that her aunt was simply attempting to discredit her so that Elvira would appear more attractive to Erskine, and that Erskine wished her to go against her aunt and join him, Jane does not defer but rather stands up to him (even though it may have been in her best financial interests to acquiesce in hopes of marrying him). In not submitting to his selfish request, Jane attempts to show Erskine that virtuous behavior is honorable in and of itself, even in the face of what he calls " "tyranny." Like Emily Hammond, then, Jane makes no attempt to indulge her own wishes despite perhaps being justified in doing so.

Following Jane's refusal, Erskine proves himself to be just as immature and morally underdeveloped as most of the seducers in earlier sentimental novels. His response illustrates how far he has to go to cultivate the virtuous sensibilities needed in a model affectionate marriage: “'Duty!' exclaimed Erskine; 'leave all that ridiculous cant for your aunt: I abhor it. I have your promise, and your promise to me is surely as binding as your duty to your aunt [emphases Sedgwick's]." Jane stands firm, however, in the face of his scorn: "“That promise was conditional,' replied Jane, 'and it is no longer in my power to perform it"' (Sedgwick 80). Jane leaves the room after this exchange, and Mrs. Wilson takes the opportunity to offer Erskine Elvira as a riding companion instead. Erskine's "vanity, which had been piqued by Jane, was soothed by this tribute," so he accepts; the two of them depart the next day, dressed in all their finery (such as Jane never wore), and "Elvira had penetration enough to detect the weakest points in the fortress she had to assail; and so skilfully and successfully did she ply her arts...that Erskine scarcely thought of Jane, and we fear not once with regret" (Sedgwick 80-1). The narrator's use of "we" in describing this situation further reinforces the lesson for the reader that Erskine is on the wrong path in being concerned with vanity and appearance rather than with Jane's wellbeing. 
So, Erskine teeters between two women, one wealthy and one impoverished, much like his novelistic predecessors. However, unlike them, his own financial state is not tied to his choice in marriage partner; instead, it is his moral state — the state of his very soul — that is conditioned on his choice between these two young women, one who is spiritually lacking and one who strives to do right even in the face of "tyranny." In reissuing the stereotype of the male romantic interest, $A$ New-England Tale transforms him from a man who will not forego his financial future to win his inner moral battle (for surely both Montraville and Sanford each underwent one) into one who is offered the possibility of winning his own moral battle with the assistance of a strong, virtuous woman like Jane. Whereas Charlotte and Eliza were not morally equipped to assure their own salvation, much less that of their lovers, and whereas a character like Emily Hammond was never called to do so, in Jane Elton readers are offered a character who has the potential agency to choose to act and to choose the virtuous path at the same time.

Therefore, while A New-England Tale seems to set up several of the conventions of previous seduction novels by presenting a young female protagonist who is tempted by a handsome and charming but morally questionable young man, it also transitions from that type of novel into one that prefigures domestic tales wherein an orphaned girl must make her own way in the world, both financially and spiritually, before being rewarded with an end in happy marriage to a worthy partner. ${ }^{7}$ Edward Erskine shows his potential for being that partner later in the novel when Jane is accused of stealing money from her aunt and he believes in her innocence despite credible evidence to the contrary. However, as a transitional novel, A New-England Tale cannot fully redeem Erskine or his ilk; in the end, he is spiritually incapable of being the right

\footnotetext{
${ }^{7}$ As Nina Baym describes them, domestic novels depict "the story of a young girl who is deprived of the supports she had rightly or wrongly depended on to sustain her throughout life and is faced with the necessity of winning her own way in the world... The happy marriages with which most - though not all — of this fiction concludes are symbols of the successful accomplishment of the required task and resolutions of the basic problems raised in the story, which is in most primitive terms the story of the formation and assertion of a feminine ego" (11-12).
} 
man for Jane to marry. The one whom she ultimately does marry, Mr. Lloyd, is a man who, like so many other elements of this novel, stands as a transfigured representative of some of the conventional sources of moral authority found in most of the earlier seduction novels. It is with his help that Jane Elton is able to learn to distinguish consistently and confidently between passivity and deference. Despite her own inability to do so, Mrs. Elton was able to plant the seed of this notion in Jane before her death. The means by which she accomplished this reflects the sources of moral authority that were valued in that era.

\section{III. "She sowed the seed..."—-The Roots of Moral Authority in A New-England Tale}

While Mrs. Elton's shortcomings as a wife and mother are made apparent to the reader by the narrator's commentary within the first few pages of $A$ New-England Tale, what is also made clear is that she was nevertheless able to equip her daughter with the potential to act differently than she herself had. In one of the first descriptions of Jane, readers are told that "She seemed to have inherited nothing from her father but his active mind; from her mother she had derived a pure and gentle spirit." From the beginning, then, readers know that in little Jane reside the best characteristics of both her father and her mother. Yet, the text continues, “...this would have been quite insufficient to produce the result of such a character as hers, without the aid of her mother's vigilant, and, for the most part, judicious training" (Sedgwick 8). In other words, even though Mrs. Elton herself is incapable of moving beyond her own passivity in order to act on her own or her daughter's behalf in the face of her husband's vices, she has still been able to endow her actively virtuous child with a different philosophy. Before her death, Mrs. Elton, while "negligent of some of her duties," had "watched over the expanding character of her child, with Christian fidelity... she sought to fortify her child's mind with Christian principles. She sowed 
the seed, and looked with undoubting faith for the promised blessing" (Sedgwick 23). In thus indoctrinating her daughter by planting the seed of God's love in her, Mrs. Elton is able to equip Jane with the potential to develop agency even though she herself has failed to embrace its possibilities; paradoxically, that act may signal her own potential for a kind of vicarious salvation, enacted through her daughter, despite the passivity that led to her death.

Because this novel turns on the reconfiguration of female passivity into the more active virtue of feminine deference when viewed retrospectively as transitioning from the norms of female behavior in seduction narratives to those more commonly seen in domestic tales, Mrs. Elton is clearly not portrayed as strong enough to accomplish this vital task alone: "In the formation of her child's character, she had been essentially aided by a faithful domestic, who had lived with her for many years, and nursed Jane in her infancy" (Sedgwick 8). Mary Hull, readers are told, "was endowed with a mind of uncommon strength, and an affectionate heart"; these gifts remind readers of the ones they were told, on the same page, that Jane herself had from her father (an "active mind") and from her mother ("a pure and gentle spirit"). Unlike the submissive, non-denominational faith of Mrs. Elton that accompanied her parental abilities, however, Mary Hull was raised "by a pious mother, and early and zealously embraced the faith of the Methodists" (Sedgwick 8). Mary Hull is an exceptionally hard worker who possesses the virtuous traits of "practical good sense, industriousness, efficient habits, and handy ways [emphasis Sedgwick's]" (Sedgwick 8-9). Moreover, her possession of an "affectionate heart" hearkens back to the language of conversion that asserted a change of heart as necessary for salvation, thereby suggesting that she has already made such a conversion whereas Mrs. Elton's "pure and gentle spirit," in its passivity, may not have been able to make the same claim. Unlike Mrs. Elton, a reader would be hard pressed to imagine Mary Hull as passive in any situation, 
including that of her own salvation or that of her young charge, Jane. After Mrs. Elton's death, Mary Hull takes on the dual role of standing as both a surrogate mother to young Jane and as a representative of the Methodist contention that good works, rather than faith alone, as was asserted by traditional Calvinist doctrine, were necessary for salvation.

In combining the embodiment what had typically been two separate sources of moral authority in previous sentimental novels — religious discourse and parental figures—into characters that function as both parental and religious authorities, this novel defines one of the features of the transition to domestic writing. While A New-England Tale maintains some of the discursive features of novels like Charlotte Temple or The Coquette in that its prescribed religious doctrines are somewhat vague and rarely overly dogmatic, it nevertheless speaks out clearly against "the horrors of Calvinism." Furthermore, it valorizes certain thinly-veiled tenets of Unitarianism in much of its religious discourse. Besides Mary Hull, two other figures epitomize certain religious characteristics, namely Calvinism and its antithesis: Mrs. Wilson, the sister of the late Mr. Elton, who reluctantly takes Jane in following her parents' deaths and thus operates as a kind of mother figure, and Mr. Lloyd, a Quaker widower who functions as a surrogate father to Jane before eventually becoming her husband.

Mary Hull cannot take Jane in and raise her herself after the deaths of the Eltons because she is a servant and does not have the means to do so; due to their class difference, no one even suggests such a thing. Defining one's proper role in life, including respecting the boundaries of class distinctions, is an ongoing theme of this story. However, Mary Hull's status as a servant does serve two other narrative purposes: first, it places her in a submissive position similar to that of any wife to her husband or of any person in relation to God, which affords readers an example of effective deferential behavior, and, second, it necessitates a distance between her and 
Jane that aids Jane in learning to make decisions and to act on her own behalf as she may not have done had a forceful personality like Mary's been more consistently involved in her day-today life. The condition of servants is explained by the narrator early on in the novel: "We believe there are many instances of intelligent and affectionate service, that are rarely equaled, where ignorance and servility mark the lower classes" (Sedgwick 8). In other words, "ignorance and servility" are not desirable traits in servants, but "intelligence and affection..." are, as long as they are maintained within the bounds of class distinctions. This sentence immediately precedes the initial description of Mary Hull as "endowed with a mind of uncommon strength, and an affectionate heart," and thus marks her as one who embodies the characteristics of "intelligent and affectionate service"; indeed, the narrator remarks that "she had the virtues of her station in an eminent degree" (Sedgwick 8). Furthermore, readers are told, Mary "never presumed formally to offer her advice to Mrs. Elton; her instincts seemed to define the line of propriety to her; but she had a way of suggesting hints, of which Mrs. Elton learnt the value by experience” (Sedgwick 9). This ability of Mary’s to influence Mrs. Elton indirectly but effectively is one that parallels the role of the ideal deferential, but not passive, wife.

Sedgwick combines in Mary Hull this embodiment of effective deference with the religious zeal of Methodism in her everyday life. When Jane is despondent over her situation and the deaths of her parents, it is Mary who comforts her and listens to her. Mary does not, however, attempt to "soften the trials of dependence" when she speaks of the "demands [Jane] would have on her integrity, her patience, and her humility" in living with her Aunt Wilson. She tells her instead,

...do not be down-hearted. There has One 'taken you up who will not leave you nor forsake you.' 'The fires may be about you, but they will not kindle on you.' 
Make the Bible your counselor; you will always find some good word there, that will be a bright light to you in the darkest night: and do not forget the daily sacrifice of prayer; for, as the priests under the old covenant were nourished by a part of that which they offered, so, when the sacrifice of praise is sent upward by the broken and contrite heart, there is a strength cometh back upon our own souls: blessed be his name, it is what the world cannot give. (Sedgwick 18-19) Mary counsels Jane to turn to God, to offer praise and sacrifice so that she may be nourished and strengthened by it, and not to despair. This wise counsel "fell upon a good and honest heart, and we shall see that it brought forth much fruit," according to the narrator (Sedgwick 19).

This spiritual advice is immediately followed by worldly advice as Mary and Jane prepare the Elton's house and their possessions for the creditors who will assume them as payment of her family's debts. When Jane wonders if she might be allowed to keep her mother's Bible, Mary replies, "“Certainly....no one will dispute your right to it; it is not like worldly goods, we will not touch the spoils, though we were tempted..." (Sedgwick 19). Other than this one item and her own clothing, which Jane was allowed to keep by the terms set by the creditors, Mary and Jane take nothing else from her family home. While they are packing up, Jane receives a note from her Aunt Wilson recommending that she "secure some small articles which would never be missed"; Jane is not sure how to proceed and so hands the note to Mary, who tells her, "'No, Jane, let us keep clean hands, and then we shall have light hearts"” (Sedgwick 1920). Even though her aunt has more right as her guardian to command her behavior, Jane listens to Mary and refuses to keep any of the "spoons, table-linen, [or] her mother's ivory workbox" as had been recommended by her aunt. This small refusal epitomizes Jane's future behavior in 
dealing with her aunt and shows readers that passivity is not to be valued in the face of potentially immoral acts.

Jane's Aunt Wilson functions as a narratorial and moral opposite to Mary Hull; when she takes Jane in, she takes the place of Jane's mother in recommending certain behavior, and she also functions as an outspoken religious authority throughout the novel, albeit one, as a representative of Calvinism, whose advice is immediately discredited by the narrator or others. Just before readers are introduced to Mrs. Wilson for the first time, the narrator steps in and directly explains the key problem with Calvinist doctrine, "We fear there are many who think there is merit in believing certain doctrines; who, mistaking the true import of that text, 'by grace are ye saved,' quiet themselves with having once in their lives passed through what they deemed conviction and conversion, and from thence believe their salvation is secure. They are like the barren fig-tree; and unless they are brought to true repentence, to showing their 'faith by their works,' we fear they will experience its just fate" (Sedgwick 10-11). Just after this, Mrs. Wilson and her two sisters, all professed and devout Calvinists, argue over who will have to take Jane in. They are Mr. Elton's family (Mrs. Elton apparently had none), so readers may presume that they are also morally corrupt as he was; in fact, later it is mentioned that "Mrs. Wilson's character might have been originally cast in the same mould with Mr. Elton's, but circumstances had given it a different modification" (Sedgwick 22). Their modified version of this familial corruption is quickly revealed to be more insidious and subversive than his was as it masquerades as religious piety. The women argue and even quote Bible verses in discussing Jane and her fate. One sister, Mrs. Convers, recommends that Jane be put to work somewhere as a servant; the other one, Mrs. Daggett, boasts that she has just agreed to adopt a needy Cherokee so she cannot possibly afford to take Jane in as well. Mrs. Wilson is the only one who considers taking Jane in herself, but 
only out of a sense of maintaining an appearance of goodness in response to her sisters' lack of it: "There was something in this harsh counsel which touched Mrs. Wilson's (the younger sister's) pride, though it failed to awaken a sentiment of humanity" (Sedgwick 12). She begins to speak of God and duty by quoting the Bible, but readers are told that "Mrs. W.'s tongue was familiar with many texts, that had never entered her understanding, or influenced her heart" (Sedgwick 13). In short order, then, Mrs. Wilson is set up as a kind of false prophet, one who pays lip service to righteousness and publically preaches against "sinful practices" but whose soul is corrupt nonetheless. When the sisters ask if Jane has "'experienced religion,"” Mrs. Wilson quickly tells them “" no,”” and says, ““...when I talked to her of her corrupt state by nature, and the opposition of her heart, (for I felt it to be my duty at this peculiar season, to open to her the great truths of religion, and I was faithful to her soul, and did not scruple to declare the whole counsel,) she looked at me as if she was in a dumb stupor..."' (Sedgwick 16). Of course, poor little Jane had been subjected to this religious harangue just after her mother's funeral had taken place.

The character of Mrs. Wilson, besides speaking for Calvinist doctrine, is also reminiscent of Mrs. Hammond's behavior as a wife and mother in Kelroy. As a wife, Mrs. Wilson was neither passive nor deferential to her now-deceased husband: "She had married early in life a man, who, not having energy enough for the exercise of authority, as weak and vain, tenacious of the semblance, and easily cozened by the shadow, when his wife retained the substance" (Sedgwick 22). The value of traditional patriarchal gender roles is further reinforced when the narrator holds both Mr. and Mrs. Wilson responsible for their situation: "Mrs. Wilson, without having the pride of her nature at all subdued, became artful and trickish; she was sordid and ostentatious, a careful fellow-worker with her husband in the acquisition of their property, she 
secured to herself all the praise in the expending of it" (Sedgwick 22). By condemning both the husband and the wife for not fulfilling their proper roles- - he is passive and she is active but they publically maintain the opposite appearance - the novel shows the danger of reversing the expectations for proper male and female behavior. Besides failing to defer to her husband while still retaining the form of doing so, Mrs. Wilson similarly fails to understand her duty to submit to God beyond the surface level: "Mrs. Wilson had fancied herself one of the subjects of an awakening at an early period of her life; had passed through the ordeal of a church-examination with great credit, having depicted in glowing colours the opposition of her natural heart to the decrees, and her subsequent joy in the doctrine of election. She thus assumed the form of godliness, without feeling its power" (Sedgwick 22). After her husband's death, Mrs. Wilson alone is in charge of the rearing of her children, and, "As might be expected, her family was regulated according to 'the letter,' but the 'spirit that giveth life' was not there...Mrs. Wilson's children produced such fruits as might be expected from her culture. The timid among them had recourse to constant evasion, and to the meanest artifices to hide the violation of laws which they hated; and the bolder were engaged in a continual conflict with the mother" (Sedgwick 23).

When Jane comes to live with Mrs. Wilson, she does her best to submit to her as duty requires but still maintain her own sense of morality. After her aunt discovers that Jane has not taken the items from the house before its sale as she was told to, Jane stands up to her, but in a respectful way: “'I did not understand your note, Ma'am, to contain positive orders; and Mary and I did not think it was quite right to take the things." Mrs. Wilson responds, "Right! pretty judges of right to be sure. She a hired girl, and a Methodist into the bargain. I don't know how she dares to judge over my head; and you, Miss, I tell you once for all, I allow no child in my house to know right from wrong; children have no reason, and they ought to be very thankful, 
when they fall into the hands of those that are capable of judging for them"' (Sedgwick 37).

Mrs. Wilson thus personifies for readers the error of submitting passively to both parental and religious voices of authority in the face of immoral behavior; virtuous republican mothers should be teaching their children how to choose moral behavior just as the Bible should teach its adherents to do the same. Here, though, Mrs. Wilson condemns a religion like Methodism, which asks its followers to act on their own behalf in performing good works, while simultaneously deriding the value of teaching children to do the same. Had Jane only had Mary Hull, a servant, as an example of how to resist such thinking, she may have eventually been worn down by her life in the Wilson household; indeed, her romance with one who appears favorable but is immoral at heart in the form of Edward Erskine suggests that she is on the edge of just such a precipice. However, another parental and religious role model takes an interest in Jane's life, and it is his influence that ultimately saves her from such a fate.

Mr. Lloyd is introduced to readers just after the scene where Mr. Elton's three sisters decide where Jane is to live; his introduction at this juncture reads as a corrective to the poor character, behavior, and claims of piety of those women. He had been travelling with his wife and young daughter in hopes of effecting a change in Mrs. Lloyd's health because she was rapidly succumbing to consumption when they were forced to stop due to her declining condition. They did so, fortuitously, just outside of the unnamed town where A New-England Tale takes place. ${ }^{8}$ Mr. and Mrs. Lloyd, as early as this third chapter of the novel, stand as models of ideal, affectionate marriage, as readers are told that "An extraordinary attachment subsisted between Mr. and Mrs. Lloyd, which had its foundation in the similarity of their characters, education, views, and pursuits" (Sedgwick 25). In specifying the similarity of their "characters, education, views, and pursuits," their marriage is portrayed as one between near equals rather

\footnotetext{
${ }^{8}$ It is barely disguised as Sedgwick's hometown, Stockbridge, Massachusetts.
} 
than one between a dominant and a submissive individual; indeed, they "were so much alike in their characters, that one seemed the soft reflection of the other" (Sedgwick 26). After being told that both Lloyds are Quakers, their marriage is further characterized thusly: "their happiness was not darkened by a single shadow; nor did it degenerate into selfish indulgence, but, constantly enlarging its circle, embraced within its compass all that could be benefitted by their active efforts and heavenly example." Moreover, unlike the Eltons and the Wilsons, the Lloyds "lived after the plain way of their sect; not indulging in costly dress or furniture, but regulating all their expenses by a just and careful economy, they seldom were obliged to stint themselves in the indulgence of their benevolent propensities" (Sedgwick 27). As the Lloyds travel through the countryside of Connecticut and Massachusetts, they reflect on God's "Providence" that the inhabitants of such places are not affected by the extremes of city dwelling as they are in Philadelphia (from whence they had just come and the city where Kelroy takes place) but are instead "cast into a state of society the happiest for their moral improvement, where they had neither the miseries of poverty, nor the temptations of riches" (Sedgwick 28). Religious ideals are thus tied to societal ones in that the novel recommends both a proper way of living a godly life and a proper place to do so. Moreover, in depicting a pastoral community as that proper place, the novel subtly embraces a Unitarian view of God as eminently present in nature. ${ }^{9}$ In fact, Mr. Lloyd later comments that this scene reflects "a more perfect and intimate union of the sublime and beautiful" (Sedgwick 34). ${ }^{10}$

It had been Mr. Lloyd's idea that they should travel in hopes of improving Mrs. Lloyd's health, and, even though she knows in her heart that her time on earth is coming to an end, she

\footnotetext{
${ }^{9}$ For further discussion of Unitarian values, see E. Brooks Holifield's chapter, “Unitarian Virtue," pages 197-217 of his study.

${ }^{10}$ Taking a cue from English Romanticism, the "sublime," in $19^{\text {th }}$-century American philosophy, was defined as God's awesome presence expressed in nature.
} 
defers to his wishes. By doing so, she is able to be depicted as her husband's equal but also as one who chooses to submit to him in order to make him happy. This parallels her submission to the will of God as well; she tells her husband: "'Prepare thy mind for the "will of the Lord." I could have wished to have lived, for thy sake, and my little one; but I will not rebel, for I know all is right"' (Sedgwick 27). When the time of her death appears imminent and no longer avoidable, they cease their travels just outside of the village where the story takes place. It is so beautiful that Mrs. Lloyd looks at her daughter and says, "'I could wish thy path led along these still waters, far from the stormy waves of the rude world..." Mr. Lloyd, knowing she is near death, tells her, "If that is thy wish, my love...it shall be a law to me." Here, even in death, Mrs. Lloyd embodies the ideal mother by hoping to guide her child's future path by having her live in a place that is conducive to a godly life, but her response to her husband also highlights her depiction as an ideal wife: “"Dear Robert, I have no wish but to leave all to thy discretion, under the guidance of the Lord"' (Sedgwick 34). In voicing her opinion about her child's upbringing but then immediately deferring to her husband's wishes, "under the guidance of the Lord," Mrs. Lloyd demonstrates for readers exactly what it means to be an actively deferential and virtuous wife rather than merely a passive one.

After Mrs. Lloyd's death, Mr. Lloyd cannot bear to leave her final resting place, so he stays in town until he hears of the sale of Mr. Elton's property. He buys the house and all of its contents from the Eltons' creditors, at which point readers learn for the first time of its idyllic location: “...the grounds descended gradually to the Housatonick, whose nourishing dews kept them arrayed in beautiful verdure. On the opposite side of the river, and from its very margin, rose a precipitous mountain, with its rich garniture of beach, maple, and linden; tree surmounting tree, and the images of all sent back by the clear mirror below" (Sedgwick 35). This pastoral 
description once again aims to show readers God's presence in nature. Because Jane has spent her childhood in such a place, they can surmise that the atmosphere has contributed to her character as well. When Mr. Lloyd moves in to Jane's childhood home, he quite literally becomes another father of a daughter in this house; as a Quaker who is concerned with doing God's work and who has experienced an ideal marriage, he steps into the role previously occupied by Mr. Elton and transforms it.

Mr. Lloyd does not just stand figuratively as an example of an ideal father, however; he also actively becomes a surrogate one to Jane as he helps to guide her life and her decisions. Because Jane and Mary Hull chose to leave so many possessions in the house rather than taking them as Mrs. Wilson had recommended, when Mr. Lloyd discovers them he generously offers Jane the opportunity to retrieve some of these personal items, and this serves to introduce them to one another. Had Jane not acted morally in regards to those items, she may not have had the chance to meet Mr. Lloyd and develop an ongoing friendship with him. So, she is rewarded for her good choice by meeting the man who embodies all of the wonderful qualities that were so lacking in her own father. Because he needs someone to look after his daughter and keep his house, and because Mary Hull has no employment now that the Eltons are gone, Mr. Lloyd hires Mary Hull to perform many of the household duties of a wife and thus completes the surrogate family for Jane. Mary, as a servant who knows her place in the world, understands that she is merely a placeholder for this position, but Mrs. Wilson, whose grasping and selfish character allows for such assumptions, suggests to Mary that "“... it is a great risk for you to live with him; for, if nothing worse comes of it, you may be sure there is not a person in this town that won't think you are trying to get him for a husband.",11 Mary responds that Mr. Lloyd is "“a gentleman

\footnotetext{
${ }^{11}$ Mary's affirmation of one's proper place in life is confirmed one other time at the end of the book when she tells Jane, “'I thought to myself then you seemed to feel just as I do when I hear the sound of James' voice; not that I
} 
far above her condition in life; and therefore she thought no person would be silly enough to suppose she took the place from so foolish a design as Mrs. Wilson suggested"' (Sedgwick 37). This allusion to one's condition and class in life serves to reinforce the pervasive notion in $A$ New-England Tale that true happiness can only be found by actively and happily performing the prescribed duties of one's place in life, whether that place be as a husband, a wife, a daughter, or a servant; those who strive to go beyond that place, as Mrs. Wilson often does, only ensure their own unhappiness as they are surely attempting to disregard God's plan. So, while this novel illustrates the joys of actively seeking one's own salvation rather than passively assuming one is among God's elect, it also reinscribes for readers the notion of doing so within the bounds set up by a righteous God; although these bounds also reinforce a culture of patriarchal authority, they nevertheless allow women to challenge that culture when doing so upholds God's laws for living a virtuous life. Respecting those boundaries, along with the societal ones exemplified by Mary Hull, is crucial to one's happiness. Because she does so, Mary is rewarded later in the story with a happy marriage to a fellow Methodist of her own class. ${ }^{12}$

After their initial meeting, Mr. Lloyd develops what is, at first, a fatherly interest in Jane. He feels sorry for the young orphan girl: "The gayety of her childhood had been so sadly checked by the change of her fortunes, that her countenance had taken rather a serious and reserved cast. Mr. Lloyd's benevolent feelings were awakened by her appearance" (Sedgwick 43). He encourages Jane to come by frequently to visit Mary and his infant daughter, Rebecca, who had grown quite fond of Jane. When a new "seminary" opens for local children to complete mean to compare myself to you, or James to Mr. Lloyd, but it is the nature of the feeling [emphasis Sedgwick's] -it is the same in the high and the low, the rich and the poor"' (Sedgwick 180).

${ }^{12}$ The man Mary marries is James, the long lost son of John of the Mountain, who figures so prominently in the embedded seduction narrative that will be discussed in the next section of this chapter. James had left town ten years prior because Mary would not marry him (he had no religion at the time and was poor besides); after long years of travel in India, his heart was finally moved to convert to Methodism, and he returned home having made his way in the world. A coincidence of this kind, one that occurs at precisely the right moment and ties up several narratorial loose ends, is typical of sentimental, domestic writing. 
their education past the grammar school level, Jane yearns to attend because, as the narrator tells readers, "knowledge is one of the best helps and most certain securities to virtue" (Sedgwick 51). ${ }^{13}$ She says nothing, however, when her Aunt Wilson makes arrangements for her own children, Jane's cousins, to attend because she knows that her aunt will not pay for her, and it is not in her nature to complain. Mr. Lloyd, nevertheless, has heard from Mary Hull that Jane's "spirit wearies with the life she leads," so he decides to pay for Jane to attend the school because he "had often regretted, that it was so little in his power to benefit Jane" (Sedgwick 52). Jane is extremely grateful for the gift and works earnestly to be worthy of Mr. Lloyd's kindness. During her time in school, Jane "improved in mortal and immortal graces" under Mr. Lloyd's watchful eye; in fact, "the development of her character seemed to interest and delight... [him] almost as much as the progress of his own child" (Sedgwick 76).

Mr. Lloyd is not only interested in Jane's intellectual progress, though; he wishes her to learn to make right choices in life as well. In desiring this, however, he does not simply tell her what to do or how to act; instead, he lets his own life serve as a virtuous example while still allowing her to make her own decisions. In this way, as in so many others, he acts as the novel's binary opposite to Mrs. Wilson in terms of parental and religious authority. Whereas she tells Jane that "'my word must be your law; you must not hesitate to do any thing that I require of you; never think of asking a reason for what I command"' (Sedgwick 38), Mr. Lloyd tells Jane, "'thou hast wisely and safely guided thy little bark thus far down the stream of life; be still vigilant and prudent, and thou wilt glide unharmed through the dangers that alarm thee"” (Sedgwick 82). While Mrs. Wilson comments that "“If my children, though they are my flesh and blood, are not elected, the Lord is justified in their destruction, and I am still. I have done

\footnotetext{
${ }^{13}$ Women's education is increasingly valued in the era of republican motherhood as women needed to be educated in order to subsequently educate their sons (and daughters). Claiming that it also serves to aid in virtuous conduct, as A New-England Tale does here, only furthers this valuation.
} 
my duty"” (Sedgwick 85), Mr. Lloyd, "considered the discipline of habits and opinions infinitely more salutary than the direct and coarse interference of power" (Sedgwick 181). Finally, while Mrs. Wilson advocates to Jane the public act of "going to meeting" as the best means of worship and tells her that "no pleasures ever prevent my going," (Sedgwick 79), Mr. Lloyd takes Jane on nature walks where he points out "the constellations in their brightness" and "spoke of the power that formed, and the wisdom that directed them" in a way "that infused a soul into all nature" (Sedgwick 82). Throughout the novel, then, the narrator counsels readers against Mrs. Wilson's methods of parenting and her means of worship while validating those of Mr. Lloyd.

Mr. Lloyd's religious discourse is not, however, dogmatic in recommending Quakerism to readers. In fact, as has been seen, his comments on nature often reflect a thinly-veiled Unitarian philosophy, much like Sedgwick's own. Lest readers be confused, though, the end of the novel clarifies the matter once and for all when Jane and Mr. Lloyd are about to be married: "...he was no sectarian; his understanding was too much elevated, and his affections were too diffusive to be confined within the bounds of sect. Such ties could not bind such a spirit." The text goes on to explain that "If any sectarian peculiarities had interfered to restrain him in the exercise of his duty, or while acting under the strong impulses of his generous nature, he would have shaken them off 'like dew-drops from a lion's mane”' (Sedgwick 181). Accordingly, deference to any one religious sect functions much like conjugal deference in that it must be challenged if it interferes with virtuous behavior. Mr. Lloyd clearly believes that marrying Jane is virtuous; the narrator explains that he sees her as one "whose whole life... [was] animated by the essential spirit of Christianity." This "essential spirit of Christianity" means more to Mr. Lloyd than his membership in the Society of Friends, so he quietly, without telling Jane, 
"determined now to inform his society of his choice, and to submit to the censure and exclusion from membership that must follow" (Sedgwick 181).

Mr. Lloyd is spared "the painful necessity of breaking ties which were so strong” by Jane herself as she exemplifies for readers one last time the proper behavior of a virtuous wife by deferring to her husband in her ultimate choice of worship (Sedgwick 181). Clearly, she has a choice to make, and neither she nor Mr. Lloyd assumes that she will passively acquiesce in such a decision. Like in other instances throughout the novel, he allows Jane to come to her own determination about this as well. After deliberating on the issue, quietly and to herself, she tells him that "with your consent and approbation, "I mean to be a "member by request" of your society of friends"” (Sedgwick 182). Mr. Lloyd is delighted with this news but, as a model affectionate husband would, he considers Jane's feelings rather than only his own when he tells her: "“This, indeed, converts to pure gold the only circumstance that alloyed my happiness; but do not imagine, dear Jane, that I think it of the least consequence, by what name the different members of the christian family are called" (Sedgwick 182). This statement dismisses the idea that any particular sectarian dogma needs to be followed by readers in order to live a virtuous and godly life while it also reinforces the ideals of affectionate marriage. Similarly, Jane, in her response, demonstrates the deferential role of wifely duty: "BBut you think it right and orderly [emphasis Sedgwick's],' she replied, smiling, 'that the wife should take the name of the husband?"” Mr. Lloyd responds, “'I think it most happy, certainly”” (Sedgwick 182). In deferring, whenever possible and wherever virtuous, to her husband's happiness, the contention that deference is the proper role for women is strengthened; that Jane does so on the cusp of her marriage demonstrates her readiness to assume this role and valorizes the notion that true happiness may be found only in what is "right and orderly" according to God's plan. In 
becoming a wife, she will not subjugate her will entirely to her husband's as her overly-passive mother did, but, in marrying such a virtuous man as Mr. Lloyd, whom one cannot imagine acting immorally and therefore needing his wife to correct him, readers may assume that she will be able to maintain the pleasure of deferring to his happiness throughout their marriage.

\section{IV. “...their hands were joined, whose hearts were 'knit together"' - Reader identification and the Reward of Happy Marriage}

In becoming Jane's husband, Mr. Lloyd perfects the image of the ideal father as seen in novels like Charlotte Temple and The Coquette by transforming it into one of a father whom the young, female protagonist can actually marry; the ideal husband is a father in this era. In marrying her idealized father figure, Jane is transformed also, from a daughter into a wife, and, simultaneously, from a wife into a mother to Mr. Lloyd's young daughter, Rebecca. Whereas characters like Charlotte Temple and Eliza Wharton exhibited some degree of potential female agency but no complementary moral abilities, and while a character like Emily Hammond displayed admirable moral sensibilities without a parallel ability to act in her own best interest, Jane Elton in A New-England Tale shows readers a protagonist with whom they may safely identify without fear of either moral degradation or utter self abnegation, both of which would ensure her own destruction. Unlike the characters in those novels, this text does not end in her death but rather in her happy marriage to a man whom she loves. The path to this marriage is not a straight or simple one, however; the novel offers and rejects two other possible romantic paths before showing this one to be the only virtuous option. Jane's reactions as she encounters these other paths model for readers a heroine from whom they may learn how to gauge their own reactions to similar situations and with whom they may safely identify as they experience her challenges vicariously. 
The first romantic option Jane encounters, before she has even begun to entertain the affections of Edward Erskine, comes in the form of her older cousin, David Wilson, who had been away at college when her parents died. When he comes home for a long visit, he pays "particular attention" to his cousin, "partly to gratify a passing fancy, and partly from opposition to his mother and sisters." Jane, who has mostly been ill-treated by her aunt and other cousins, is, at first, "grateful, and returned his kindness with frankness and affection" (Sedgwick 61). David Wilson is later revealed to be a degenerate gambler, drinker, and seducer, but readers do not know this yet and neither does Jane. Before finding out anything specific about his behavior or his character, though, Jane eventually decides that she is "obliged, by the freedom of his manners to treat him with reserve" (Sedgwick 61). In other words, when David starts behaving too freely with her, just as a charming seducer like Montraville or Sanford would have done, she immediately withdraws from him rather than responding to his attentions as Charlotte or Eliza would have done.

While her rejection of his affections may not seem overly significant in the moment, later in the novel Jane and her readers will have cause to be grateful that she was so quick to repel him. Her modeling of such discretionary behavior for her readers helps them to reconstitute the expected role of the female protagonist in seduction tales by reforming her from a girl who follows her desires without a meaningful moral check on them to one who discriminates carefully which male company she will entertain. This point is reinforced by the embedded seduction narrative told in the middle of this novel. Jane is approached by a kind but eccentric man called "John of the Mountain" and asked to come to his out-of-the-way house that evening. She tells him that she does not know the way, but he responds, "You shall have a guide, Miss. Don't be afraid; 'tis not like you to be afraid, when there is good to be done" (Sedgwick 86). 
Her "guide" turns out to be a woman called "Crazy Bet."14 In guiding Jane up the mountain to John's house, Bet is also guiding her metaphorically, in nature, to a direct experience with God's grace. As they climb the mountain, Bet tells Jane: "'Strong of heart, and light of foot, you are a fit follower for one that hates the broad and beaten road, and loves the narrow straight way and the high rock"' (Sedgwick 91). These God-given characteristics of Jane's show her to have the potential to follow God's path for her. It is by God's grace that Jane had the strength of character to resist the charms of David Wilson; her strenuous journey up the mountain, which draws her figuratively ever closer to heaven, will take her to one who did not have such grace.

When Jane reaches the humble cottage of John of the Mountain and his wife, he tells her the story of a young girl, Mary Oakley, whom he had found on the mountain that morning just after she had just given birth to a daughter. Mary was orphaned at a young age, and, as the narrator relates, she had been raised by her grandparents who had "denied themselves every comfort, that they might gratify every wish, reasonable and unreasonable of their darling child." Mary loved her grandparents dearly, but "like other spoiled children, she never testified that love by deferring her will to theirs" (Sedgwick 99). Mary was raised, then, to become the perfect potential victim for a seducer. But because Mary is not the protagonist or even a main character in the novel, readers of her story are able to identify instead with Jane as she listens to it being told indirectly by John of the Mountain. Jane was summoned to the mountain by John to meet Mary and her baby because he believed that Jane had the power to bring Mary's seducer to a "sense of right" and to be "some comfort for her"; he tells Jane that he told Mary that

\footnotetext{
${ }^{14}$ Crazy Bet is a homeless wanderer in the village who lost her reason when her beloved was drowned the day before their wedding. Her excessive emotion is given as the reason for her condition, but that condition also frees her to experience God's creation outside of the bounds of conventional society and religious doctrine: "She has been seen, when the sun came rejoicing over the eastern mountain's brow, and shot its first clear brilliant ray on the grave, to clap her hands, and heard to shout, 'I see an angel in the sun, and he saith "Blessed and holy is he that hath part in the first resurrection: on such, the second death hath no power; but they shall be priests of God and of Christ, and shall reign with him a thousand years"”'(Sedgwick 14).
} 
"everybody in the village knew you for the wisest and discreetest, and gentlest" person (Sedgwick 102).

Mary's seducer is a student at the college in her hometown: David Wilson. When Mary pursued him to his mother's house, unbeknownst to Jane or anyone else in town, she did so because she "felt certain she would not survive her confinement, and hoped to secure the protection of Wilson for her infant" (Sedgwick 100). He rejects her utterly and tells her that it is “impossible for him to do any thing for her" (Sedgwick 101). Here, the narrator takes a moment to remind readers, once again, that it was his mother's responsibility to raise him well, but "he began with a nature more inclined to evil than to good...his mother's mismanagement had increased every thing that was bad in him, and extinguished every thing that was good...the continual contradictions of his mother's professions and life, had led him to an entire disbelief of the truths of religion, as well as a contempt of its restraints" (Sedgwick 101). In once again reinforcing the notion that the combination of proper parental and religious authority is required to raise responsible, moral children, the narrator's comments also serve to encourage readers to identify with Jane and, in so doing, plant the seed that will potentially help them to follow the correct path regardless of their own life circumstances. Jane was not raised by model parents, but that does not condemn her to a fate like Mary's because she has had other role models to fulfill those obligations. Readers who similarly do not have ideal parents may learn these lessons by emulating a protagonist like Jane.

Unfortunately, Jane does not have a chance to intervene with David Wilson on Mary’s behalf. By the time she reaches the top of the mountain, the baby has already died. Mary, who will not let go of the dead child, has a terrible fever and believes Jane is an angel, come to take her baby to heaven. Mary tells Jane that "there is none but an angel would look upon me with 
such pity." When Jane reached for the child, Mary "uttered a faint scream-became suddenly pale... and fell back on the pillow" (Sedgwick 103). She, too, has died. John of the Mountain, who is old and wise and resides in nature so close to God, tells Jane that he is sorry she came such a long way for nothing; but, he adds, "to the wise nothing is vain, and you are of so teachable a make, that you may have learned some good lessons here" (Sedgwick 104). Jane has gone up on the mountain, close to heaven, and witnessed the lesson that all seduction tales strive to teach. In embedding this well-known narrative mode within an entirely different kind of story, A New-England Tale signals to its readers that they too may journey back down the mountain with Jane and progress beyond this type of experience. The direct use of a traditional seduction narrative, safely related from a distance as only a minor character's story, also constructs a link between past literary modes for women's writing and future ones in this novel we can now read as transitional.

In furtherance of that link, Jane's story continues by first embracing and then rejecting another potential romantic partner, Edward Erskine. When Jane comes down off the mountain and returns to her aunt's house later that night, she finds David Wilson stealing money from his mother's desk. Jane generously considers that perhaps David was stealing the money to help Mary Oakley, so she conveys the night's events on top of the mountain to him. Jane has thought too highly of him, however; although he admits that "'Hell has no place bad enough for me,"” he will not put the money back because he is stealing it to pay off his jailed accomplices who are threatening to expose his part in a counterfeit money-making endeavor. He pulls out a gun and threatens to kill himself if Jane will not keep his secrets. Jane responds, “'I will promise any thing. Do not destroy your soul and body both"' (Sedgwick 106). Because Jane believes that 
redemption and forgiveness are always a possible choice for any sinner, she does not want David to kill himself and lose those possibilities.

The next day, Mrs. Wilson discovers Jane's handkerchief, which was dropped the night before, on the desk from which her money has gone missing; she accuses Jane of stealing the five hundred dollars. Jane, who cannot reveal David's guilt without breaking her promise, declares that "'The consequences I must abide, and I do not fear them, nor shrink from them, for I am innocent, and God will protect me"” (Sedgwick 111). This scene sets up the next romantic narrative prospect for Jane, and it cautions readers against making the mistake of letting emotion rather than reason guide one's decision making, especially when parents, who should be trusted to prevent such things, are absent. Here, though, the lesson is not told from a reflective distance as the seduction one was. The parents in seduction narratives may have offered advice, but the young girl in such tales generally disregarded it and recklessly pursued a path of her own destruction, as Mary Oakley did; in later tales, like Kelroy, the parents tended to be absent, dead, motivated by selfish ends, or unreliable, which left the female protagonist open to destructive possibilities much as Emily Hammond was. Whereas the virtuous Jane cannot be imagined as being susceptible to seduction, she is able to be seen as vulnerable to an error in choosing a suitable potential husband given her youth and the absence of any actual parents to guide her in her choice.

Just at the moment when it becomes clear that David will not disabuse his mother of the notion that Jane has stolen the money, Edward Erskine enters the house, and Jane, who "could not endure the thought of degradation in Erskine's esteem," runs from the room crying (Sedgwick 111). He demands to know what has happened, but when Mrs. Wilson relates the matter she is shocked to find that "he neither expressed horror, nor indignation, nor resentment 
towards the offender" (Sedgwick 112). Instead, he asks to see Jane, and, with no evidence whatsoever to contradict Mrs. Wilson's accusations, he states, “I believe you are perfectly innocent of that and of every other crime; I do not wish you even to deny it"' (Sedgwick 113). Jane tells her aunt that she will " "not remain another night beneath a roof where I have received little kindness, and where I now suffer the imputation of a crime, of which I cannot think you believe me guilty"' (Sedgwick 112). She starts to leave the house but is gently prevented by Erskine, who is deeply affected by her vulnerable emotional state. He gives her a "passionate declaration of his affections, followed by such promises of eternal truth, love, and fidelity, as are usual on such occasions" (Sedgwick 113). The voice of the narrator steps in at this point to excuse Jane's hasty response to Erskine's avowals: “At another time, Jane would have paused to examine her heart, before she accepted the professions made by her lover, and she would have found no tenderness there that might not be controlled and subdued by reason." However, because Jane has no actual parents whose consent must be obtained for marriage, because she is emotionally vulnerable in the wake of her aunt's denunciation, and because in her youth she has confused gratitude for believing in her innocence with love, Jane "received Edward's declarations with the most tender and ingenuous expressions..." (Sedgwick 114).

While a mistake such as this may have been fatal or, at least, destructive to previous heroines of sentimental novels, A New-England Tale offers readers the possibility of a different outcome. When Erskine proposes that they marry immediately in order to protect Jane from her aunt, she refuses him and declares her intention to accept a teaching position, "for a few months at least," because she has "too much pride...to involve you in the reproach I may have to sustain." She says that she trusts that something will happen to place her "beyond the reach of suspicion, and reward as well as justify your generous confidence." Erskine still wants to marry 
her as soon as possible, but "he was obliged at length to resign his will to Jane's decision" (Sedgwick 114).

So, although Jane has consented to become his wife, she is able to justify the fact that she will not defer to Erskine in his wish to marry her immediately because she believes that a higher moral good will be served if she does not. She does not want her marriage to be tainted by even a hint of impropriety, so, paradoxically, she is actually serving Erskine's best interests even though he does not perceive it as such. Ironically, Jane's orphan status and her wish to act virtuously despite the pain it may cause her afford her a narratorial possibility that would not have been open to young ladies who had parents or husbands to whom they would have been obliged to defer. She is able to choose to leave her aunt's house, go to work, and support herself as a teacher and yet maintain her virtuous state. Therefore, she is able to model a kind of agency for her readers without any tinge of immorality to taint it; such narrative possibilities would often be opened to orphans in later women's novels as well. Providentially, the time Jane spends on her own also allows time for Erskine's true character to be revealed.

Jane ventures up the mountain one more time and finds truth there once again. The day before she is to start her second term as a teacher, which happens to be just after she has finally consented to set her wedding date, she decides to take a long walk and visit Old John of the Mountain, whom she has not seen since that fateful night with Mary Oakley. When she reaches his land, she is quite surprised to find a brand new house rather than his old log cottage. When she asks him how that came about, he tells her a long story involving the young Woodhull brothers from whom he had rented his land. They had unjustly pulled down his old house and thrown him and his wife out. His story also reveals the name of the slick lawyer who had defended the brothers when he took them to court: Edward Erskine. Clearly, John does not know 
of Jane's engagement to the man; he also mentions that Erskine and the brothers spent "night after night...at the gambling club," which horrifies poor Jane. When John asks Jane if she can guess who it was that gave him the money to buy the land back from the brothers and build his new house, she correctly assumes it to be Mr. Lloyd (Sedgwick 134). She travels back down the mountain, armed once again with the truths provided thereupon, and resolves to speak to Erskine directly about what she has learned. In her goodness, she hopes that John may have been misinformed.

The conversation Jane has with Erskine is the turning point of the novel. Readers know at this point that Jane must extricate herself from her engagement to Erskine or risk the same destructive fate as her forebears in women's novels, but it is not clear how that will be possible without Jane betraying the principles she holds so dear-Jane cannot break her pledge to marry Erskine without breaking her word and incurring much shame. However, readers will once more be taught that deference should not be maintained in the face of immorality, even if doing so risks going against cultural norms. When Jane arrives back at the place where she is boarding, Erskine is there, "perturbed and angry." He tells her that " "there is a tradition in our family, that no Erskine was ever ruled by his wife; and the sooner the lady who is destined to be mine learns not to interfere in my affairs, the more agreeable it will be to me, and the more safe for herself '” (Sedgwick 139). In opening this critical conversation with such a statement, Erskine shows that he is looking for a wife who will be passive rather than deferential; Jane still waits, though, to hear him out before passing judgment. Erskine explains that he believes that Jane has asked her friend, Mr. Lloyd, to keep an eye on him because "from the beginning of their engagement Mr. Lloyd had undertaken the surveillance of his morals [emphasis Sedgwick's]" (Sedgwick 140). He describes to her the many ways that Mr. Lloyd had taken it upon himself to offer unsolicited 
advice, especially recently in regards to the situation with John of the Mountain. Jane denies the accusation, and he believes her, but this only offends Erskine further; he is even more incensed that Mr. Lloyd had presumed "“to haunt me like an external conscience”" (Sedgwick 142).

After Erskine tells her his version of John of the Mountain's story, including an admission that he did indeed play cards for money at times, Jane begs him to "'Tell me nothing more," as she has "“heard enough to make my path plain before me"” (Sedgwick 143). She says that the "illusion has vanished"" and asks him to "examine your heart as I have examined mine, and you will find the tie is dissolved that bound us; there can be no enduring love without sympathy; our feelings, our pursuits, our plans, our inclinations, are all diverse." At first, Erskine calls her "unkind" and "ungrateful," but then he relents and offers to "abandon the club, give up my friends" (Sedgwick 144). Jane will not reconsider and says, "II would make any exertions, any sacrifices, to render you what I once thought you. I would watch and toil to win you to virtue - to heaven. If I believed you loved me, I could still hope, for I know that affection is self-devoting, and may overcome all things." But Jane does not believe he truly loves her, and, what is more concerning, she knows that he has never truly embraced any religion; she says, "'religion is the only sure foundation of virtue...religion alone can produce unity of spirit; alone can resist the cares, the disappointments, the tempests of life"' (Sedgwick 145). Because Erskine does not submit his own actions to any set of religious doctrines, Jane knows that she cannot have any hope of reforming him. She will not marry him. The narrator tells readers that "Edward was habitually under the dominion of self-love, and every other emotion soon gave place to the dread of being looked on as a rejected man," so he leaves for New York the next morning (Sedgwick 146). In taking up residence in a city like New York, Erskine figuratively places himself in sin and thus ends his inner moral struggle. 
Throughout the novel, Jane had tried to teach Erskine the lesson of deference that he should have learned from his parents. She forces him, on more than one occasion (as has been discussed), to defer his will to hers; she had hoped that she might thereby also have taught him to defer his will to a higher power, to God, and thus choose to seek his own salvation. But when she learns that his reform has only been in her presence and that outside of it he has been behaving so sinfully, she can no longer believe that he has the potential to live a virtuous life and says, "'Oh Edward! if in the youth and spring of your affection, I have not had more power over you, what can I hope from the future?" (Sedgwick 144). Moreover, she tells him, "WWen I first heard you trifle with the obligations of religion, and express a distrust of its truths, I felt my heart chill. I reproached myself bitterly for having looked on your insensibility on this subject as the common carelessness of a gay young man, to be expected, and forgiven, and easily cured. These few short months have taught me much...I have felt that my most sacred pleasures and hopes must be solitary"' (Sedgwick 145). Jane's remarks show readers the dangers of believing one might reform a sinner solely by a woman's love; while she may guide him, it is God alone who can bestow His grace for such a change.

Sedgwick's anti-Calvinism does not suggest, then, that the sinner may choose salvation where God has not offered it. Indeed, wise John of the Mountain's comments to his wife, Sarah, after Jane leaves are prophetic of this very lesson. Sarah expresses hope that Jane "may cure Mr. Erskine of his faults,"” but John tells her, “"No, no Sarah... he has been a wilful spoilt child from the beginning: he is a comely man to look to, and he has a glib tongue in his head; but he is all for self — all for self, Sarah. You might as well undertake to make the stiff branches of that old oak tender and pliable as the sprouts of the sapling that grows beside it, as to expect Miss Jane can alter Erskine. No-he alone can do it with whom all things are possible"" (Sedgwick 
135-6). In other words, if a "“sapling"” is not bent to the right path (by its parents) while it is still young and "“pliable,"” only God may effect such a change later in life.

Jane's decision opens the way for the hoped-for romantic attachment between the two most idealized figures in the novel, Jane and Mr. Lloyd. Upon initially hearing of Jane's engagement to Erskine, readers had been told that Mr. Lloyd "had loved Jane first as a child, and then as a sister; and of late he had thought if he could love another woman, as a wife, it would be Jane Elton" (Sedgwick 120). His metaphoric progression from father to brother to husband is thus summed up for readers long before the events that take place for Jane on the mountain. They know, then, that they may safely hope for the marriage to take place. Once Jane breaks her engagement to Erskine, the wedding seems inevitable. When Mr. Lloyd learns of Jane's decision to break it off, the narrator comments that "There is not a happier moment of existence than that which a benevolent being enjoys, when he knows that the object of his solicitude and love has passed safely through trial, is victorious over temptation, and has overcome the world. This was the joy that now a thousand fold requited Mr. Lloyd for all his sufferings in the cause of our heroine" (Sedgwick 170).

After continuing in her work as a school teacher for several months, during which time Rebecca Lloyd is one of her students, Jane and Mr. Lloyd are finally engaged. The scene in which their engagement takes place is left to readers' imaginations; unlike the previous false declarations that were made between Jane and Erskine, which readers had to witness so that they might learn from them, this scene is much more discrete. The narrator claims that "We are warned from attempting to describe the scene... by the fine remark of a sentimentalist, who compares the language of lovers to the most delicate fruits of a warm climate-very delicious where they grow, but not capable of transportation. Much is expressed and understood in a few 
sentences, which would be quite unintelligible to those whose faculties are not quickened by $l a$ grande passion, and who therefore cannot be expected to comprehend the mystics of love" (Sedgwick 178). The narrator clearly makes the assumption here that readers of this story are young and have not yet experienced real love; indeed, it is for such as these, whose character, to use John of the Mountain's words, is still "'tender and pliable as the sprouts of the sapling,"” that this tale has been told. The reward of this happy marriage are as much for them as it is for Jane and Robert Lloyd, whose "hands were joined, whose hearts were 'knit together"” in ideal, affectionate marriage (Sedgwick 183).

\section{Conclusions}

By the end of the novel, all of the Wilsons have reached an unhappy, disgraceful end. Martha, the oldest daughter, had eloped with a tavern keeper fairly early in the story; David, who left for New York soon after he stole his mother's money, was jailed for attempting to rob a mail stage, a capital offense, but then he escaped when his mother refused to hire a lawyer to help him, and eventually he runs off to the West India islands, to "make his debut as pirate, or in some other character for which his training has equally qualified him" (Sedgwick 171) — he does, though, write to Mr. Lloyd in order to clear Jane's name once and for all in the matter of the missing money; and Elvira, Mrs. Wilson's last hope, is seduced by a wandering French dance instructor and runs off with him before the end of the novel. Mrs. Wilson herself is finally confronted with her own hypocrisy and bad parenting when David sends her a letter on his way out of the country: "The letter was filled with execrations. 'If I have a soul,' he said, 'eternity will be spent in cursing her who has ruined it"” (Sedgwick 173). He goes on to say, "Mother, mother!...you have destroyed me. You, it was, that taught me, when I scarcely knew my right 
hand from my left, that there was no difference between doing right and doing wrong, in the sight of the God you worship; you taught me, that I could do nothing acceptable to him. If you taught me truly, I have only acted out the nature totally depraved, (your own words,) that he gave to me, and I am not to blame for it. I could do nothing to save my own soul... according to your own doctrine"” (Sedgwick 174). Mrs. Wilson, for the first time in the novel, falls silent, and Jane fears that "the violence of her aunt's passion would over destroy her reason"; for a short time, David's letter combined with Jane's ministrations seems to give way to a "newly awakened conscience” in Mrs. Wilson. She is, however, beyond true understanding and repentance: “...the impression was transient; the chains of systematic delusion were too firmly riveted - the habits of self-deception too strong, to be overcome" (Sedgwick 174).

Ironically, even though Mrs. Wilson, like Mrs. Hammond in Kelroy, appears on the surface to be a kind of potential model for female agency in that she appears to act so forcefully, she herself believes that she has no actual agency whatsoever as she subscribes to the dictates of Calvinism that say that only God may choose to save: "'The natural man can do nothing towards his own salvation. Every act he performs, and every prayer he offers, but provokes more and more the wrath of the Almighty," according to Mrs. Wilson (Sedgwick 166). Jane tries to teach her the religious lesson of the novel: that while God's grace is still what makes salvation possible, it is offered universally, not particularly, as Calvinists believe. Moreover, the penitent sinner must admit his or her sins and then work faithfully and actively to overcome them rather than passively accepting the state of depravity that Calvinists believe is natural. After reading the letter from David and listening to Jane's words in response to it, the narrator describes Mrs. Wilson's mute state with a Bible verse: "her 'countenance was changed, her thoughts were troubled, and her knees smote one against the other."' This seeming epiphany does not last; once 
Mrs. Wilson regains her ability to speak, she also regains her ability to enact what Jane calls, “daring hypocrisies,... self-delusions,...[and] lies” (Sedgwick 167).

So, A New-England Tale ends happily for all virtuous parties and horribly for all immoral sinners, unlike other sentimental novels that ended in the destruction or death of most of their primary characters. In offering readers a happy ending, this novel enacts the final step on the path towards domestic women's writing wherein happy endings would become the norm. Jane's happy outcome requires two separate trips up the mountain in order for her to come to understand her own abilities and to illustrate the lessons of this novel adequately for its readers. While she is taught the stereotypical lessons of her novelistic forebears on that mountain, her journey also allows her to realize the potential power of her own ability to make virtuous choices on her own behalf. Despite the fact that she chooses marriage rather than a teaching career as the means to her happiness and thus reifies many conventional patriarchal values, Jane Elton still models for readers the latent power of deference. As Mary Hull says: "“I often think to myself, Jane, that your life, and Mr. Lloyd's too, are better than preaching"” (Sedgwick 122). 


\section{Chapter Five: \\ Female Selfhood as Constituted in Popular Women's Novels of the 1850s: The Wide, Wide World; The Lamplighter; and Ruth Hall}

\section{Introduction}

When Nina Baym first cataloged the works she termed "woman's fiction" in her study of nineteenth-century women's writing, she claimed that those "novels all tell, with variations, a single tale" (Woman's Fiction 11). When she revised her original study fifteen years later, Baym wrote in her Introduction to the Second Edition that "The protagonist — and readers vicariously_ learn that women must become people to survive in a difficult world; they also learn that women can [emphasis Baym's] become people, because persons, selves, is what they all potentially are" (Woman's Fiction ix). Baym's assessment is not unfounded, and she certainly articulates her contention exhaustively; however, I believe that, rather than merely serving as variations on a theme whose goal is to educate women on their own potential selfhood, many of these novels can be viewed progressively, in a line of ever-increasing agency reaching back from Charlotte Temple and moving all the way through the heyday of nineteenth-century American women's writing in the 1850 s and, eventually, beyond. Therefore, I think that the women whose lives these novels chronicle and the readers who read them already knew they could become selves, and so, rather than merely modeling that latent possibility of selfhood, they model actual modes of potential agency for their female readers. In my view, then, the decades of novelistic development and religious evangelism preceding the 1850s had already produced the vision of the potential female self to which Baym refers.

We have seen the emblematic female self progress from one that could only begin vicariously to imagine acting on her unarticulated desires in Charlotte Temple to one that could conceptualize and directly voice those desires in The Coquette to one that envisioned doing so 
within the bounds of virtuous behavior in Kelroy to one that did so without it resulting in her own self destruction in A New-England Tale. That novel in particular helped to lay the early foundation for the development of the female bildungsroman that came to maturity in the 1850 s. However, in her new introduction to the second edition of her study, Baym does not classify these works as bildungsromanen but instead terms them "novels of education" because she believes they value "self-discipline" over "self-expression" (Woman's Fiction xix). The binary Baym has constructed between the novelistic valuation of self-discipline and self-expression is a false one, in my view, because I believe that both modes function in these novels at the same time. Such a plural functioning reflects the narrative structure of these novels wherein the journey of salvation undertaken by these female protagonists requires her to be both subject to the will of God and yet free to choose to seek His grace.

When viewed in this way, we can see that A New-England Tale offered its female readers a way to imagine agency in terms of their own salvation and thereby afforded them a path to selfexpression bolstered by the normative theological doctrines of that era. It also helped to pave the way for a figurative system to develop in later novels wherein salvation could be conceived in non-theological terms, particularly by the middle-class Protestant women who were their primary readers. ${ }^{1}$ For example, by the middle of the nineteenth century, many of these women found a public forum for the increasingly secular aspects of salvation in the work of benevolent societies. Lori D. Ginzberg's Women and the Work of Benevolence: Morality, Politics, and Class in the $19^{\text {th }}$ Century United States examines the tensions between the benevolent causes that relegated women to a separate sphere while at the same time affording them an empowering sense of solidarity based on those experiences. She contends that many middle-class Protestant women

\footnotetext{
${ }^{1}$ One of Jane Tompkins' crucial arguments in Sensational Designs is that "the popular domestic novel of the nineteenth century represents a monumental effort to reorganize culture from the woman's point of view" (124).
} 
based their own self image and self worth on the principles inherent in that sphere and used it to justify their entrée into the public world of benevolent work. A few others chose public careers in such fields as the arts, teaching, or publishing as a means of effecting a kind of secular salvation of the female self while still maintaining a persona of womanhood consistent with the domestic ideals of the day. Alison Piepmeier's Out in Public: Configurations of Women's Bodies in Nineteenth-Century America posits the visibility of a woman's body out in public as a means of examining the intersection of traditionally binary positions such as private or public, victim or agent, appropriate or deviant. She seeks to show the instability of such binary categories by examining the public and private lives of several prominent women. ${ }^{2}$ The development of a more worldly female self that has the ability to choose rightly a course of action in order to effect a productive change in her own life and potentially in her society accordingly becomes valorized as a moral act in and of itself as later novels and their heroines come to productive fruition. ${ }^{3}$

\footnotetext{
${ }^{2}$ Specifically, Piepmeier considers Anna Cora Mowatt, a popular stage actress and playwright from the mid-1840s to the mid-1850s; Mary Baker Eddy, a woman who, despite the fact that she suffered severe and recurrent illness for much of her life, nonetheless lived for nearly 90 years and wrote a book, Science and Health, that became the founding document of the Christian Science religion; and Sarah Josepha Hale, editor of the popular Godey's Lady's Book for forty years. Piepmeier claims that these women "present themselves in the very terms that more familiar readings of womanhood preclude and position themselves as simultaneously public and private, enacting agency even in the midst of oppression and limitations" (213).

${ }^{3}$ Despite the increasing focus on secular behavior, religious development had not stalled during this time; in fact, some denominations were undergoing radical divisions and theological reconceptualizations as they struggled to contend with popular philosophical trends, in particular the move towards rationalism and evidential theologies. By 1855, Lutherans, for example, "were on the verge of divisions over the normative status of the historic Lutheran confessions" as American Lutherans sought "to bring Lutheran theology into closer conformity with a more rational form of orthodoxy," according to Holifield (397). Even Catholic theologians during this time struggled to contend with rationalism and thereby "assimilate the evidential tradition in a distinctively Catholic manner" by depicting "virtuous living as the best exemplification of piety" (Holifield 415-16). Evidential philosophy found its most vigorous supporters in the Transcendentalism that evolved from Unitarianism, however: "...founders of the movement were a group of liberal clergy in New England who believed that Unitarian theology had promoted a Lockean rationalism that privileged the senses over spiritual faculties...the scope of the movement soon embraced literature, literary criticism, and social reform" (Holifield 434).
} 
In order to see her own potential to act in the world, the female protagonists in these novels, and their readers, had to have already conceived of themselves $a s$ selves. Their challenge is not to develop such a self, as it may have been in earlier novels, but to take full control of that self and then use it to effect some beneficial change in her own world, be it familial, communal, social, or political. The popularity and increased production of women's novels in the $1850 \mathrm{~s}$ fostered a rapid evolution that brought to fulfillment certain ideals of selfhood and agency that had previously taken decades for other novelistic discourses even to suggest. In so doing, these works challenged existing genre conventions much more quickly than had any other novels of previous eras. If we view them in a line of development using certain exemplary texts beginning with the publication of The Wide, Wide World in 1850, we can see how the assumptions and norms of that novelistic realm progressed into those of The Lamplighter in early 1854 and, in turn, of Ruth Hall in late 1854. The role of the mother in the growth of the main character's sense of self, the valuation of spiritual and/or communal ties over familial bonds, and the emerging ability of the female protagonist to interact with a secular world and thereby ensure her own salvation all advanced and were challenged along with the genre itself.

Because the spiritual and, later, secular development of these main characters' abilities to choose to enact their own salvation matured over the course of the plot of these novels, I examine that line of growth in terms of the progression of the plot events of these novels. The plot of The Wide, Wide World gives readers a protagonist who actively chooses to seek salvation and thereby become a true Christian; every turn of the plot and intervention of other characters, both positive and negative, works to foster in Ellen Montgomery a sense of self reliance-even when she herself professes not to wish it-heretofore not usually seen in sentimental, novelistic discourse. In The Lamplighter, that self reliance is taken beyond the realm of the spiritual, where 
it had been confined in The Wide, Wide World, and brought into the material and the matrimonial ones as Gerty makes choices that enable her to support herself financially (and emotionally) and to marry a man who is her equal rather than an older, wiser, father figure. Finally, Ruth Hall refigures many of the conventions of domestic literature by featuring a coming-of-age story that paradoxically begins with a happy marriage and ends with its title character learning to become self reliant in every sense of the word; Ruth's hard-won independence is never safely reinscribed within the bonds of matrimony that may have necessitated the end of her career, either. The rapid progression of agency exemplified by the heroines of these novels becomes the foundation for future modes of female agency to flourish in later texts.

\section{The Wide, Wide World}

On the opening page of Susan Warner's runaway best seller, The Wide, Wide World (1850), young Ellen Montgomery seats herself at a window to gaze out at the bustling world while her sick mother rests. She finds so many spectacles to engage her attention that readers may wonder if the girl had never before noticed the world outside that window. As she watches the daylight gradually fade away on the busy street, she sees a lamplighter making his way down the sidewalk to bring light to the night. The illumination from his lamps serves to wake Ellen from her hours-long reverie by making her aware of the darkness in the room in which she sits. She decides to bring the fire back to life and tidy up the room, saying to herself, "'Who says I can't poke the fire? Now, let us see if I can't do something else." Ellen seems amazed at her own thoughts and actions, as if she had never before been left alone for long enough to consider what she herself might wish to do. She gives the impression of being a sheltered child whose entire daily life has been mapped out by adults up until this moment. Her mother's illness, 
though, combined with the light from the street outside, has literally and figuratively woken Ellen up: "The veriest moth could not have followed the light with more perseverance than did Ellen's eyes, till the lamplighter gradually disappeared from view, and the last lamp that she could see was lit; and not till then did it occur to her that there was such a place as in-doors" (Warner 10).

This opening scene encapsulates for female readers the overall lesson of The Wide, Wide World — namely, that following the external "light" can lead to an internal awareness of the darkness in one's own inner room and the realization that one can choose to do "'something else." So, the purpose of the remainder of the book is two-fold: first, to show Ellen Montgomery and her readers the world as illuminated by the power of God's grace (symbolized by the light); and, second, to encourage them to use their newfound awareness to take hold of themselves - to bring that light within, and then to do something useful in that newly-illuminated space (to "“poke the fire"” and then do "“something else"”). Although Ellen may appear throughout much of the novel not to have control over the particular circumstances of her life, her experiences are designed (presumably by a benevolent God) to help her to see God's light in the world and then to bring it within to illuminate her soul so that she may use it to do “"something else."

Ellen's challenge is to learn how to continue to find God's light and do "'something else" with it in her increasingly adverse world. Much like Jane Elton in A New-England Tale, Ellen's mother is her first teacher and symbolic lamplighter, but, as this opening scene indicates,

\footnotetext{
${ }^{4}$ This reflects Tompkins' contention that for Susan Warner and most of her contemporaries, "The highest function of any art... was the bringing of souls to Christ" (149). Moreover, Tompkins explains that everyday tasks could be endowed with spiritual significance if they furthered the "establishment of Christ's kingdom" by ordering the world: "The welfare of the nation, conceived in millenarian terms as the bringing of God's kingdom to earth, depended upon the virtue of the individual citizen; any task no matter how small, could be seen as either helping or hindering the establishment of Christ's kingdom" (156).
} 
she will not be a lasting presence in Ellen's life. Ellen's earthly father is taking her mother away for her health, and her heavenly Father will soon take her away permanently. Ellen reacts to this news with a "violent burst of grief that seemed for a few moments as if it would rend soul and body in twain." Without her mother's presence, Ellen cannot regulate herself enough to see the light or muster the will to follow it on her own: "For her passions were by nature very strong, and by education very imperfectly controlled," as the narrator explains (Warner 11). Ellen is young, and her "education" in controlling her reactions to her world has only just begun; after indulging their mutual tears for a few moments, her mother tells her, “'my child, this is not right. Remember, my darling who it is that brings this sorrow upon us; though we must [emphasis Warner's] sorrow, we must not rebel...You will hurt both yourself and me, my daughter, if you cannot command yourself. Remember, dear Ellen, God sends no trouble upon his children but in love; and though we cannot see how, he will no doubt make all this work for our good"' (Warner 12). ${ }^{5}$ To emphasize her hope that a relationship with God will ultimately supplant the maternal bond, Ellen's mother sells her own mother's ring to buy Ellen a Bible before she leaves town (and thus literally transforms the worldly into something spiritual that may be passed down from a mother to a daughter) and tells Ellen that “"He wounds that he may [emphasis Warner's] heal. He does not afflict willingly. Perhaps he sees, Ellen, that you never would seek him while you had me to cling to"” (Warner 41).

When Jane Elton lost her mother, it was not portrayed as a part of Jane's path to salvation, and it did not require her to leave her hometown or all of the other people in her world who loved and cared for her. The development by mid-century of the genre convention that

\footnotetext{
${ }^{5}$ Despite the decline of Calvinism, most of the free-will denominations still embraced much of its dogma while also asserting the belief that adherents could choose to accept the universally-offered grace of God; so, the Puritan-era belief that God tests those whom He loves was carried over in much of sentimental literature. Ellen is being asked to accept her mother's Christ-like deference to the will of God. As Holifield explains, "Christ's active righteousness was his perfect obedience to the divine law; the passive was his perfect submission to death on the cross" (114).
} 
demanded such a radical break also depicted the female protagonist as a lone pilgrim who must effect her own salvation because the notion of a female self as capable of doing so had already become widely accepted in contemporary evangelical theology. ${ }^{6}$ Ellen, though, must part from her mother and be cast out into the world where the lessons only sketched by Mrs. Montgomery will be fully realized; namely, she must choose to seek God, she must learn to defer her will to the will of God, and she must learn to love God above all earthly others. These lessons will be repeated many times over before Ellen absorbs them completely. Her next teacher, as she sets out on her solitary journey to her father's sister's house in the country, is a kindly stranger she meets on the ship. After being teased by her young female co-travelers over the style of her bonnet, Ellen retreats alone to the deck where "There was enough darkness in her heart to put a veil over all nature's brightness," even though she had thought when she first stepped outside "how very fair every thing was" (Warner 68).

Ellen has lost sight of the light of God in the world because she cannot stop her flow of emotions in the absence of her mother. But a kind gentleman sees her sorrow and speaks to her, asking, "“Ellen, do you know who it is that sends sickness and trouble upon us?"” She replies, "“Yes, sir, I know; but I don't feel that that makes it any easier." So the stranger asks, "“Do you know why [emphasis Warner's] he sends it? He is the God of love,- - he does not trouble us willingly, - he has said so;- - why does he ever make us suffer? do you know?"” (Warner 69). Ellen says she does not, so the gentleman explains, "'Sometimes he sees that if he lets them alone, his children will love some dear thing on the earth better than himself, and he knows they

\footnotetext{
${ }^{6}$ Marilyn J. Westerkamp explains that, in the decades following the Revolution, “...the ethos of resignation to divine providence was replaced with a conviction that persons could control their own fate. This growing confidence in human ability infiltrated individuals' theologies, and the passivity of the believer was being replaced with activity. Individuals were doing something about their salvation - something more than preparing for grace." She says that although women, in the first part of the nineteenth century, often spoke of themselves as passive vessels waiting to be filled with the Holy Spirit, by mid-century, "Women had begun to use their own voices and act out of their own desires" (179-181).
} 
will not be happy if they do so; and then, because he loves them, he takes it away, - perhaps it is a dear mother or a dear daughter,- - or else he hinders their enjoyment of it; that they may remember him, and give their whole hearts to him. He wants their whole hearts, that he may bless them"” (Warner 69-70). When, after some prompting, Ellen confesses that she loves her mother better than her "'Saviour," the stranger helps her to see that only by taking her mother away can Ellen be guided to God. He counsels her to turn to God, to pray to Him, to ask Him for sight as the blind man did, so that she may learn to love Him best; he also explains to her the ways in which Christ loves all of His children just as a mother loves hers. Finally, he tells her that Jesus can change her "sinful heart"" so that she may use it to love Him best of all, and he encourages her to pray for such a change. At the stranger's urging, Ellen promises to try to open her heart to God and become a true Christian as her mother had wished. Finally, he gives her his own book of hymns to help guide her to God after their journey together is over (Warner 70-79).

Before Ellen and this caring gentleman part ways, he gives her advice designed to help her apply the love of Jesus in her life by suggesting that she needs to forgive the girls who were unkind to her: "“Then, my dear Ellen, you have something to do, if you were in earnest in the resolve you made this morning. If ye forgive unto men their trespasses, my Heavenly Father will also forgive you; but if you forgive not men their trespasses, neither will my father forgive your trespasses!" As Ellen struggles with this concept, she looks silently at the shore, but "she did not in the least know what she was looking at" until the sun's rays glided behind the distant hills, and "There were no clouds hanging over his setting, to be gilded and purpled by the parting rays, but a region of glory long remained, to show where his path had been" (Warner 80). As Ellen gazes upon the path of the light, her heart is awakened by following it with her eyes, and she agrees to try to forgive the Dunscombe girls. Ellen must not only follow the glorious path of the 
light—-she must also use it to do "something else" good for herself and in the world by forgiving them.

Possessing a clear desire to seek her own salvation, although initiated by her mother, indicates that the main character of a novel such as this has already developed a self capable of imagining doing so; she must, therefore, seek to understand and control that self enough to bring about this change in her heart and thereby in her life. Consequently, much of the rest of the novel will be devoted to the enactment of a series of challenges designed to help Ellen learn to understand her self and thus take control of it so that she may eventually enact her own salvation and thus effect change in her world. Her Aunt Fortune, so named as Ellen will be most fortunate for having known her in terms of the improvement of her soul, provides the first in a long line of these adverse developments in Ellen's life. Fortune is an efficient country housekeeper who runs her family's farm with the help of a caretaker, Mr. Van Brunt; life in her household, where Ellen must learn to make her own bed and help with the household chores, is very different from the pampered city life she had previously enjoyed. Small skirmishes over their disparate ways lead Ellen to retreat frequently to her room with fits of sobbing where she cries to herself and thinks things like, “'I never can like aunt Fortune-it's of no use-I never can like her; I hope I shan't get to hate her! - and that isn't right. I am forgetting all that is good and there's nobody to put me in mind." This little tantrum leads Ellen to remember "her Bible and hymn-book, and the friend who had given it," and, "sorrowful thoughts they were; and at last, humbled and sad, poor Ellen sought that great friend she knew she had displeased, and prayed earnestly to be made a good child; she felt and owned she was not one now" (Warner 117).

Ellen's oft-repeated private tantrums over Fortune's treatment of her during her stay on the farm thus narratively appear to serve a divine purpose in that they provide an opportunity for 
her to choose to turn to God. However, besides the overt religiosity of Ellen's experiences, the fact remains that she must learn to do this on her own as there is "nobody to put... [her] in mind." So, as Ellen strives to control her passions and instead turn to prayer, she is also performing an act of agency wherein she works to choose her own behavior and her responses to her world. In the very act of learning to control her passions, Ellen is also learning how she might choose to situate herself in relation to her experiences. Accordingly, she is developing a sense of herself as a person and, in prayer, learning to imagine how she might choose to behave differently in the future. As a representative of a figurative female self, then, she has moved beyond the place achieved by Jane Elton in A New-England Tale because Jane never had to leave her familiar surroundings or had to do without a single devout friend to guide her decision making as Ellen must often do in Fortune's household.

Nevertheless, a few nights, weeks, or even months in Fortune Emerson's household could not provide enough grounds for the development of a fully actuated self in the person of young Ellen Montgomery. Although Ellen has learned to find some measure of satisfaction in performing well the chores of daily life on a farm, the narrator describes Ellen's state of mind after she has spent several hours in prayer following one of her outbursts: "It was long after midday when Ellen rose from her knees. Her passion was all gone; she felt more gentle and pleasant than she had done for days; but at the bottom of her heart resentment was not all gone" (Warner 117). Until Ellen can master this "resentment," she will never truly be in control of her self; Ellen must learn to control her behavior in order to signify, paradoxically, that she has developed the internal agency necessary for independent selfhood.

Other characters are brought in to function as lamplighters for Ellen's soul throughout the remainder of the story, most notably Alice Humphreys and, later, her brother John. Ellen meets 
Alice following her most violent fit in reaction to Aunt Fortune's behavior when she discovers that her aunt has been withholding letters from her mother. In her rage, she throws the newlydiscovered letters to the ground and flees into the woods, sobbing. Her lack of self control deprives her of both the pleasure of reading her mother's letters and the appreciation of God's beauty all around her in nature: '“Peace,' was the whisper of nature to her troubled child; but Ellen's heart was in a whirl; she could not hear the whisper" (Warner 146-7). She ventures further and further from home but finally pauses halfway up a mountain to look out over the countryside where "the sun, now near the setting, threw his mellowing rays, touching every slope and ridge with a rich warm glow" (Warner 147). The play of light on the scene suggests the presence of God to readers; in pausing to appreciate this beauty and contemplate it, Ellen signifies that she may be beginning to recognize the light of God. Ellen is not able, at this point in her development, to do more than merely recognize it for what it is, though: "She felt her own heart sadly out of tune with the peace and loveliness of all she saw...Her eyes had been filling and dropping tears for some time, but now came the rush of the pent-up storm, and the floods of grief were kept back no longer... she sobbed aloud, and even screamed, for almost the first time in her life; and these fits of violence were succeeded by exhaustion, during which she ceased to shed tears and lay quite still, drawing only long sobbing sighs now and then" (Warner 148).

Because this is a novel of female self development rather than merely one that seeks to educate women on their place in the world, Ellen requires a friend at this moment who is capable of helping to illuminate the path she may choose to take in order to seek her own salvation. The development of an independent self that is capable of acts of agency in the novels of the $1850 \mathrm{~s}$ made use of the contemporary theological notion that spiritual kinship should take precedence over blood relationships, which is why Aunt Fortune (and later the Lindsey family) is not 
depicted as able to offer spiritual guidance to Ellen. ${ }^{7}$ Instead, a new, unrelated character appears at this point: Alice Humphreys. While out on a walk, Alice comes upon Ellen in her uncontrolled, emotional state and, after comforting her for some time, suggests that perhaps she can help Ellen. Ellen responds rightly that "Nobody in this world can help me," which prompts Alice to confirm the statement by saying, “"Then there's one in heaven that can...Nothing is too bad for him to mend"' (Warner 150). Ellen confesses that she has been neglectful of her duties to pray and read the Bible because, she says, “'I was so full of bad feelings that I didn't feel fit to pray or read either"; Alice explains to her that " "that is the way with the wisest of us...how apt we are to shrink most from our Physician just when we are in most need of him. But Ellen, dear, that isn't right. No hand but his can touch that sickness you are complaining of. Seek it, love, seek it" (Warner 152). After this, Alice, who is a few years older than Ellen, becomes like a sister to her; she leads her religious and secular education (as Aunt Fortune had not previously let Ellen attend school, much to Ellen's dismay). Alice's father is a minister and her mother has died, so she keeps house for him; their family is kind, loving, and centered around doing God's work. With Alice's help and guidance, Ellen becomes much more schooled in controlling her emotions and her reactions to the fickle hand of "Fortune." When word eventually comes that Ellen's mother has died, she stays in the Humphreys household for several months until Fortune takes ill and requires Ellen to return. Alice is a constant presence throughout these trials and functions like a surrogate mother in helping Ellen learn to navigate her ever-changing world.

\footnotetext{
${ }^{7}$ Like in A New-England Tale, the chosen connections of like-minded Christians become more important than any blood relationships in this novel and many others of the 1850s. As Elizabeth Barnes explains "The emphasis on spiritual over biological kinship is consistent with a New Testament ethos that sees filial relations as determined by faith rather than blood. In the evangelical Christian scheme, family ties are represented as both voluntary and inherently reproducible: i.e., what matters is not the family into which the individual is born but the one into which the individual grows" (79).
} 
Having chosen to live through her mother's death in a household that embodies the end of the spiritual journey she has elected to take, Ellen voices the belief that she might indeed be a true Christian: "'I think I am changed,' she said to herself at last. 'I didn't use to like to read the Bible, and now I do very much;--I never liked praying in old times, and now, oh what should I do without it! - I didn't love Jesus at all, but I am sure I do now" (Warner 352). During this time, Ellen also comes to rely on Alice's brother John, who is newly home from his own studies to become a minister. John and Alice together take on Ellen's education, almost standing in for the ideal parents she had been denied; all three refer to themselves as family, and Ellen calls them her brother and sister. Once again, though, Ellen must be tested by the loss of a mother figure, Alice. As Alice lies dying, Ellen steps out into the evening to watch for John, who is away from home. The moon and stars flood light over the whole scene, prompting Ellen to wonder how long they had been shining. Although Ellen's emotions are high, she has stayed in better control of herself throughout Alice's ordeal than she did when she was originally parted from her mother. She has a kind of revelation as she realizes that the moon and stars will eventually cease to exist, but "when all they are swept away, then heaven will be only begun; that will never end!- - never" (Warner 439). Despite her sadness, Ellen bears Alice's death with more maturity and self control than she had previously exhibited in any other situation.

After this display of maturation, readers may have been hoping for an ending to this novel similar to that of A New-England Tale; Ellen's idealized father figure, John, could be the perfect man for her to marry (when she is a bit older) much like Mr. Lloyd was for Jane Elton. But the lessons of A Wide, Wide World have far more to do with a young woman's development of an ability to take charge of her self, independent of any parental or romantic figure, than they do with depicting marriage as a reward for her correct behavior. Accordingly, Ellen is not 
tempted by other romantic possibilities as Jane was; John takes over Ellen's spiritual and worldly education completely, and she almost never waivers from the virtuous path he lays out for her. Instead, providence intervenes once again to remove Ellen from her state of domestic complacency in the Humphreys' household (where she has assumed Alice's duties) and place her out in the world. The discovery of more letters kept from her by Fortune reveals to Ellen her mother's dying wishes for her: that she travel to Scotland to live with her mother's mother and be raised in her household. Ellen weeps and resists, but she eventually comes to believe (with some help from the Humphreys) that she must honor her mother's final wishes (especially because her father has drowned on the ship carrying him home by this point in the novel). She travels to Scotland and becomes part of the Lindsey household, which includes her grandmother, her uncle (her mother's widowed brother), and her aunt (her mother's widowed sister).

The Lindseys are not religious and clearly will not encourage Ellen's spiritual development; in fact, they tempt her to a more material life in their wealthy household by genuinely loving her, declaring her their daughter, and insisting she denounce America and her previous life. Ellen tries to maintain her devout habits, but she truly loves her new family even though she is rarely allowed time for reading her Bible or attending church and must attempt to keep the light of God alive in her heart without any external supports. Ellen is particularly torn between her devotion to her uncle, whom she adores, here on earth and her love of God. She illustrates for readers the more treacherous aspects of deference as Jane Elton could not because here Ellen's deference is not challenged in the face of immoral acts, but instead it is maintained out of love for a man, her uncle, who is not corrupt but merely misguided.

Over time, as she tries to resist losing her identity as a Christian and an American and yet still maintain a virtuous and deferential attitude towards the uncle whom she loves and who has 
become more and more like a father to her, Ellen decides that she "shall do precisely what he tells me of course...but there are some things he cannot command; nor I neither"' (Warner 510). She also comes to the mature realization that she owes him "“a child's obedience now...God gives grace to the humble-I will humble myself"” (Warner 525). She resolves to maintain her proper deference to this male authority figure but still endeavors to stay true to herself in the “"things he cannot command." Ellen must learn to preserve her self identity, then, as she is tempted not by hardship or vice but by love. She must stand entirely on her own for the first time since believing herself to be a true Christian, with no helpful friend or stranger to offer wisdom and guidance, as Jane Elton never had to do. One afternoon, Ellen insists on attending church despite her relatives' protests; as she prays and seeks the strength to persevere in her humble attitude towards her new family's wishes, she says to herself, “'Oh, what shall I do! what will become of me if I do not watch over myself — there is no one to help me or lead me rightnot a single one - all to lead me wrong! what will become of me?"' Ellen answers her own prayer, though: "'But there is One who has promised to keep those that follow him- he is sufficient without any others-I have not kept near enough to him! That is it;-I have not remembered nor loved him-_"If ye love me, keep my commandments,"-I have not! I have not! Oh, but I will! - I will; and he will be with me, and help me and bless me, and all will go right with me"” (Warner 532).

Ellen's epiphany at this moment is not only a spiritual realization that she must rely on God rather than any others; it is also a more secular recognition that she only has herself and her own faith in God to turn to in times of trouble. No voice from heaven or external friend explains this to her; instead, she reasons it out for herself. Once she accepts this, she raises her head from her prayers and discovers her uncle sitting at the other end of the pew. Her faith in God and in 
herself has already begun to effect a change in the world in that it has literally brought a nonbeliever to church. He may not have gone out of a love of God, but his love for Ellen has brought him to a place where some small beginning may be made. Mr. Lindsey and Ellen have a heartfelt conversation, and it results in him being more confident in her affections, which ironically allows him to afford her a few new freedoms: "She had masters for the piano and singing and different branches of knowledge... and soon her riding-attendance began" (Warner $535)$.

Shortly thereafter, Ellen is so busy that, ironically, she has no quiet time for herself in which to read the Bible or pray; however, she had promised John Humphreys that she would devote an hour a day to God, so she gets up early, before breakfast, to maintain her devotions. Her grandmother almost immediately decides that it is not good for her to " "be up so long before breakfast, and in these cold mornings"”; she commands her, "Do not rise in future till I send for you." Ellen, in her newfound self confidence, decides that she must disobey. When her grandmother discovers this a week later, she asks Ellen "'Why have you disobeyed me?" Ellen replies, "Because, grandmother, I thought it was right"” (Warner 541). When asked to explain how her disobedience could possibly be "“right," Ellen responds, "“I mean, grandmother, there is One I must obey even before you'” (Warner 542). Ellen's faith has given her the moral strength to refuse to defer to her elder in the face of what is "right""; it shows her maturity and potential as an individual that she has come to this point in her development. As a reward, it seems, a kind maid who knew Ellen's mother comes to her room to check on her after this conversation because she hears Ellen crying. She gives Ellen the strength to continue in her convictions just when she felt most helpless in the face of her grandmother's demands. Her uncle hereafter effects a kind of compromise whereby Ellen will be allowed one unaccounted-for 
hour each morning after breakfast — she may use it as she pleases and also not disobey her grandmother by rising before dawn.

Not long after this, John Humphreys makes his way to Scotland from England, where he had gone to take care of some family business. He finds Ellen during a party at the Lindsey house and tells her that he will arrange things with the Lindseys so that she may keep in touch with him. She is so delighted at the prospect that she nearly abdicates her tenuous self possession; she tells him that she will write to him and says, "And I will tell you every thing about myself; and you will tell me how I ought to do in all sorts of things? that will be next best to being with you. And then you will keep me right."” But John replies, “'I won't promise you that, Ellie...you must learn to keep yourself right"” (Warner 564). This conversation demonstrates that Ellen is not yet mature enough to leave Scotland, despite all the progress she appears to have made; after all that she has been through, she still longs for someone else to take over and tell her what to do. John is truly an idealized companion for Ellen, then, because he refuses to allow her to defer her sense of authority and self righteousness to his own judgment. Instead, his reply encourages Ellen to rely only upon herself, 'to keep herself right,' and he makes no direct mention of God's authority or His role in this effort while doing so. Clearly, Ellen will only be ready to leave the Lindsey household when it has taught her true and lasting self reliance. Until then, she must stay.

The ending of Ellen's tale suggests that her choice to pursue her own spiritual salvation will allow her to effect a kind of domestic salvation as well. When John leaves England, it is with the promise that when Ellen has grown to adulthood she may choose to return to America and to him: "Three or four more years of Scottish discipline wrought her no ill; they did but serve to temper and beautify her Christian character; and then, to her unspeakable joy, she went 
back to spend her life with the friends and guardians she best loved, and to be to them, still more than she had been to her Scottish relations, "the light of the eyes" (Warner 569). Ellen has successfully brought about a vision of her own fulfillment, and so ends this novel—not in an explicit marriage, but in the promise of a happy future now that Ellen has learned that she must be the one to 'keep herself right.' In deciding her own future fate by leaving her blood relations to return to her spiritual family, the fulfilled promise of the opening of this story is seen in the light that now shines from Ellen's eyes, from the inside out, rather than only being seen by those eyes, from the outside in.

\section{The Lamplighter}

Maria Susanna Cummins' The Lamplighter (March 1854) can quite easily be viewed as the literary offspring of Warner's A Wide, Wide World; its very title and the heroic early rescuer of its female protagonist, Gerty, calls to mind the lamplighter first spied by Ellen Montgomery in the opening pages of her story. Unlike Ellen, however, whose tale began with a loving mother from whom she had to part in order to learn the lessons of God and the world, Gerty's account begins in such squalor and adversity, both material and spiritual, that one can scarcely imagine Ellen being able to subsist. Gerty's father is unknown and her mother has died; the abusive woman in whose house Gerty's mother was boarding at the time of her death some five years previous has allowed Gerty, now around age eight, to stay on as a kind of servant and whipping girl. Unlike Ellen, Gerty is quite literally cast out into the wide, wide world in a way that Ellen, who always had friends and relatives with whom to stay, never was; moreover, Gerty's tale will eventually grow beyond the time of childhood and adolescence and into young adulthood. Whereas Ellen's journey was mainly spiritual and psychological, Gerty’s is more material and 
substantive. She rather quickly learns the spiritual lessons that took an entire novel for Ellen to understand, and Gertrude brings those lessons to fruition beyond her youth and into her adulthood out in the world. In so doing, she models modes of behavior for her readers that move past the constructs of stereotypical domestic ideals and into prototypes of actual, enacted agency. Although ultimately reinscribed by the bonds of love, duty, and, eventually, marriage, Gerty's choices and actions over the course of the novel allow readers to imagine their own agency in ways previously unconsidered..$^{8}$

The Lamplighter, despite owing its genesis to The Wide, Wide World, breaks from many of the genre conventions begun in A New-England Tale and carried over into Warner's novel right from the beginning of its story. In so doing, it signals to readers its potential to transform the tale of the abandoned orphan into one in which the desire for spiritual salvation is subsumed by the overarching desire for a female character to enact her own self salvation. Unlike Jane Elton and Ellen Montgomery, Gerty has no familial ties at the beginning of the novel, so she also has not had a caring mother to indoctrinate her with a notion of God's love and saving grace and thereby inoculate her from experiencing fully the deep pain of being alone in a world without her. Whereas Jane and Ellen both lost their mothers on the cusp of their adolescence, Gerty loses hers when she is only three-too soon for her to have happy childhood memories or the direct voice of a mother counseling her to seek God to sustain her through the painful growth of adolescence. Gerty's early life is one of squalor and abuse, where "there was no one in the world who cared for her," until she encounters the lamplighter, Trueman Flint: "There was one thing,

\footnotetext{
${ }^{8}$ Baym describes the purpose of female bildungsroman in this era in her Introduction to The Lamplighter: "The depictions of young women alone in the world invited women readers to scrutinize their own situations and attempted to influence their scrutiny. The form is engaged rather than contemplative; it intends to be useful. The perfect woman whom the typical female Bildungsroman features is neither a realistic character nor a role model. She is an imaginary construct who spurs, provokes, and inspires her audience" (xi). (N.B. Baym made this contention in 1988, before her re-envisioning of the purpose of female bildungsromanen in her 1993 re-introduction to Woman's Fiction.)
} 
and one only, which she found pleasure in. She loved to watch for the coming of the old man who lit the street-lamp...when he ran up his ladder, lit the lamp so quickly and easily, and made the whole place seem cheerful, one gleam of joy was shed on a little desolate heart, to which gladness was a stranger" (Cummins 1-2). Just as the light is the only joy in the poor girl's life, she also "hated and feared the dark" and would be shut up in it as punishment by the cruel woman with whom she lived, Nan Grant (Cummins 3).

Despite her condition in life, then, from the first pages of her story Gerty shows herself to have an affinity for the light and an aversion for the darkness that signifies her inherent potential to live a godly life. The voice of the narrator confirms this: "Poor little, untaught, benighted soul! Who shall enlighten thee? Thou art God's child, little one! Christ died for thee. Will he not send man or angel to light up the darkness within, to kindle a light that shall never go out, the light that shall shine through all eternity!" (Cummins 4). So, despite these horrible beginnings, where Gerty shows herself to be "spirited, sudden and violent," she is also depicted as having the potential to have such a light kindled within her (Cummins 5).

The first sign of love and guidance in Gerty's life comes not in the form of a mother, as one would expect from the usual conventions of such novels, but in the shape of Trueman Flint, the lamplighter, who brings Gerty a kitten after accidentally knocking her over one night. The early appearance in Gerty's life, after she has shown an affinity for the light, of Trueman Flint, who functions as a kind of Christ-figure, suggests that she may be capable of a direct relationship with Jesus without needing the intermediary presence of a mother to intercede on her behalf or to direct her in seeking Him. When Nan Grant heartlessly murders the tiny kitten in a fit of rage, it precipitates the events that lead to Gerty being taken in by Trueman permanently. The tiny kitten's life is not sacrificed in vain - her death is what gives Gerty a chance at life. True is an 
old man who has lived alone most of his life; he takes Gerty in, telling her, "“All alone in this big world and so am I. Please God, we'll bide together'” (Cummins 15). "Uncle True," as Gerty calls him, provides Gerty with a loving if humble household, telling her, "“Yes, just as long as I live...you shall be my child"' (Cummins 22). He introduces her to the people-not family members of his or hers - who will become most important in her growth and development: the Sullivans and the Grahams. Mrs. Sullivan, their widowed neighbor who lives in the other side of their house, teaches Gerty the "cause of cleanliness and order, which was in her eyes the cause of virtue and happiness, so completely did she identify outward neatness and purity with inward peace" (Cummins 25). Her son, Willie, is only three years older than Gerty, and he becomes her inseparable companion throughout their childhood; unlike the father-figures transformed into romantic love interests in previous domestic novels, Willie is Gerty's equal, raised alongside her for most of their now-happy childhood: "One source of the light-heartedness that Willie and Gerty experienced undoubtedly lay in the disinterestedness and generosity of the emotion which occupied them; for, in the plans they formed, neither seemed actuated by selfish motives" (Cummins 48). Mr. Graham is a wealthy merchant who had previously employed True until one day when a horrible accident rendered him no longer fit for manual labor. Mr. Graham and his unmarried daughter, Miss Emily, looked after True until he was well enough to care for himself following the accident; Mr. Graham found True the job as a lamplighter, and his daughter has continued to provide him with favors and support. After hearing Gerty's story, she takes a heartfelt interest in the girl and pays for Mrs. Sullivan to make her some new clothes. Miss Emily was blinded in an accident years before, but, as True tells, " if the world is dark to her, she makes it light to other folks. She cannot see Heaven's sunshine outside, but she's better off than 
most people, for she's got it in her, I do believe, and when she smiles it lets the glory out, and looks like God's rainbow in the clouds"” (Cummins 22).

With Mrs. Sullivan to teach her that cleanliness is next to godliness and Miss Emily to teach her the spiritual lessons of which she has been deprived, Gerty soon becomes the very model of goodness and domestic virtue in True's life and those of her other friends. She responds to his love and the kindness of her new friends like a flower put into the sun and watered abundantly. While she must occasionally be corrected, especially from giving in to fits of temper as she had previously been wont to do while at Nan Grant's, for the most part she works diligently to show her gratitude for her new situation in life by living as she ought: "It was that deep love for her first friend, which, never wavering, and growing stronger to the last, proved, in after years, a noble motive for exertion, a worthy incentive to virtue. It was that love, fortified and illumined by a higher light, which came in time to sanctify it, that gave her, while yet a mere girl, a woman's strength of heart and self-denial" (Cummins 34). So, early in the novel, Gerty moves beyond her relationship with her mother or any other family member and instead embraces a world full of spiritual and social community.

Although it is always based in the spiritual, Gerty's development throughout the rest of the novel moves past religious salvation and towards a more secular one in a way that Ellen Montgomery would not have been capable of envisioning or enacting. Gerty's spiritual fortitude guides her choices and actions out in the world while it also serves to strengthen her resolve in them. Gerty's portrayal as an uncommonly mature girl comes to fruition a few years later when True suffers a "paralytic stroke": "During four or five years that he has cherished the frail blossom, she has been gaining strength for the time when he should be the leaning, she the sustaining power [emphases Cummins']; and when the time came,- and it came full soon,- she 
was ready to respond to the call. With the simplicity of a child, but a woman's firmness; with the stature of a child, but a woman's capacity; the earnestness of a child, but a woman's perseverance" (Cummins 88). When True dies, Gerty is taken in permanently by Miss Emily as her companion; she is more often hereafter referred to as "Gertrude," signifying her ascent into adulthood. She finishes her schooling while under the Grahams' roof and leads a pleasant life therein, although she finds Mr. Graham to be short-tempered and demanding in most regards except those which pertain to the happiness of Emily. The one blight on her general happiness is that Willie is sent by his employer to India for several years, but even this sorrow is converted to a blessing during a conversation Gertrude has with Emily following this news. Gertrude opines that "I think the world is full of trials, and that everybody gets a share"”; Emily responds that “"It is [emphasis Cummins'] the lot of humanity, Gertrude, and we must not expect it to be otherwise"" (Cummins 104). Gertrude wonders then where true happiness may be found, and Emily replies, "'Those only, my child, who have learned submission; those who, in the severest afflictions, see the hand of a loving Father, and, obedient to his will, kiss the chastening rod...It is hard, my child, and therefore few in this world can rightly be called happy; but, if, even in the midst of our distress, we can look to God in faith and love, we may, when the world is dark around, experience a peace that is a foretaste of heaven"' (Cummins 104). This lesson of Emily's is taken to heart by Gertrude; indeed, it is one she had long felt but not had deeply tested since leaving Nan Grant's until she is confronted by the doubled sorrow of True's death and Willie's departure. Now, though, not even one-third of the way through this novel, Gertrude has absorbed the lesson which eluded Ellen Montgomery for most of her story; as the narrator explains, "Gertrude had often found in time and the soothing influences of religious faith some alleviation to her trials; but never until this night, did she feel a spirit not of earth, coming forth 
from the very chaos of sorrow into which she was plunged, and enkindling within her the flame of a higher and nobler sensation than she ever yet had cherished" (Cummins 105). Gertrude has taken the light of God, the "flame of a higher and nobler sensation," into herself and allowed it to illuminate her from within; she now has a "smile of heaven-lit light that played over her features" (Cummins 105).

Had the lessons of this novel been mostly spiritual, readers could have expected little more to happen in the remaining plot other than Willie returning several years hence as a prosperous businessman now capable of marrying the deserving Gertrude. After all, that inner light did not illuminate Ellen Montgomery's eyes until the very last lines of the novel. Gertrude's inner light and strength, however, are what allow her to move out into the world and embrace a self reliance heretofore unseen in most other protagonists, although it was prefigured by a character like Jane Elton. Ironically, it is Gertrude's submission to the will of God that will afford her the ability and confidence to choose to act as she believes to be correct in other areas of her life. When Gertrude questions her own ability to take care of Willie's mother and grandfather as he requests of her before leaving, he tells her, "If I am gone five or ten years, Gerty, you will not be a child all that time, and a woman is often a better dependence than a man; especially such a good, brave woman as you will be...I always think of you, and hope you will be near them [his mother and grandfather]; for I know, if you are, you will be a greater help than I could be"' (Cummins 106). Willie, as her potential future husband, gives her the last bit of external assurance she needs to become fully self reliant in his absence. Indeed, when confronted with a situation that may have previously caused her to lose control of herself and her emotions a little while after Willie leaves town, Gertrude bears the injustice staunchly, without surrendering to any violent show of emotions: "She had conquered; she had achieved the greatest 
of earth's victories, a victory over herself' (Cummins 117). When Emily hears from another source of the wrongdoing perpetrated against Gertrude, she "expected, for several days to hear from Gertrude the story of her injuries; but Gertrude kept her trouble to herself, and bore it in silence." Indeed, even the narrator congratulates Gertrude on her maturity, saying, "This was the first instance of complete self-control in Gerty, and the last we shall have occasion to dwell upon. From this time she continued to experience more and more the power of governing herself; and, with each new effort gaining new strength, became at last a wonder to those who knew the temperament she had had to contend with" (Cummins 118).

Because Gertrude has already experienced God's saving grace and exhibited her Christian ability to submit to His will by forgiving those who have wronged her, she is free now to use that knowledge as a basis for expanding her self control and her own sense of righteousness in other areas of her life and her world. When the time comes that Gertrude must indeed look after the Sullivans, she is met with an unexpected challenge in the form of Mr. Graham, Emily's father. Just as Gertrude turns eighteen, finishes her schooling, and makes plans to accompany the Grahams on a trip where she will act as companion and eyes for Emily, Mrs. Sullivan becomes seriously ill, and her father, being by this time quite elderly and also leaning towards senility, is not in any condition to look after her. In addition, Gertrude has been offered her first teaching job, based on her superior abilities as a student. She makes plans to live with the Sullivans and help care for them while she starts her teaching job, all with Emily's blessing. Indeed, Emily considers it a remarkable sacrifice that Gertrude should give up a pleasure trip to "“repay... [her] old obligations."” Emily commends her, saying, "“...my Gerty is the brave, good girl I always hoped and prayed she might become. You are in the path of duty, Gertrude, and will be rewarded by the approbation of your own conscience, if in no other way" (Cummins 
135). “Duty" and "“conscience,"” ironically, are what afford Gertrude with an opportunity not only to return her childhood "obligations"” by taking care of the Sullivans, but they are also what open up the prospect of a well-earned career as a teacher outside the domestic sphere. And they are also what cause this female protagonist to stand up to an older, male authority figure for one of the first times in this type of sentimental, novelistic discourse.

As a result, Gertrude makes a declaration that, although said only to herself in private, is one of the most overt examples of the inherent worth of female education, independence, and free will yet exhibited in popular, sentimental literature. It moves beyond the salvation of the soul and looks past it to imbue the salvation of the self, instead, with all of the significance for which women had previously been seen as unfit. In the scene just before that declaration takes place, Gertrude tells Mr. Graham she will not be able to accompany him and Emily on their trip. He is quite indignant and angry that she should so choose; he feels that she owes him a debt of obligation for "“staying with us, where she has always been treated like a lady, and, more than that, like one of my own family!" He asks her, “'Haven't I given you the best of educations, and spared no expense either for your improvement or your happiness?"' Emily interjects here as, despite her blind and dependent state, she is a woman who has embraced the righteousness of her own sense of independence: "'Father,...I thought the object, in giving Gertrude a good education, was to make her independent of all the world, and not simply dependent upon us"” (Cummins 140). Mr. Graham pouts, saying they are both against him, and leaves the room in a fit of temper. Gertrude, who cannot sleep that night, reflects on these events. She wonders to herself, “"What right had Mr. Graham to treat me thus...? Does he consider that my freedom is to be the price of my education, and am I no longer to be able to say yes or no?"' After trying, and failing, to see any justice in acquiescing to his wishes, she concludes, “Perhaps, if I yielded 
now, and staid here living in luxury, I should continue to do so until I lost the power of regaining my independence. It is cruel in Mr. Graham to try to deprive me of my free-will'" (Cummins 143). Gertrude resolves, however, to consider Mr. Graham, who has indeed been quite kind to her over the past several years, as being motivated by interest in her well-being. She decides that she must speak with him further, but she fears he will think her ungrateful, so she resigns her worries to "Him who judgeth righteously" and looks to the light of the moon and that of the approaching dawn out her window as she prays. By that light, which reflects Heaven's light, "she found, in quiet self-communing, the strength and courage which, she felt, would be requisite to carry her calmly and firmly through the following day." The narrator further explains that Gertrude will need this strength because it was quite remarkable, "for a young girl of eighteen years, long dependent upon the liberality of an elderly man, well known as a stern dictator in his household, to suddenly break the bonds of custom and habit, and mark out a course for herself in opposition to his wishes and intentions" (Cummins 144). Unlike Ellen Montgomery who only ever directly defied her grandmother - another woman-Gertrude must choose to defy a man who has been her benefactor and who has offered her a life of travel and luxury that most women of that time would have found alluring. Indeed, when Gertrude faces Mr. Graham the next day, he is still displeased and will not listen to her pleas for understanding. He assumes, as a man at this time might, that Gertrude may feel comfortable leaving his house because she believes she has the support of another man, Willie; Mr. Graham tells her that although she has hopes that her "'Calcutta friend will support [her], perhaps come home and take [her] under his especial care,"” he believes that she is being foolish and says to her, " if you think so, you know little of the world. I daresay he is married to an Indian by this time, and, if not, has pretty much forgotten you"' (Cummins 146). 
When Gertrude responds, she says the words that would hitherto have seemed nearly impossible for a female character to utter; she makes the declaration that exemplifies her growth and development as an active self who is choosing to seek her own secular salvation: "“I assure I neither look to him or any one else for support; I intend to earn a maintenance for myself."' $\mathrm{Mr}$. Graham looks upon her with contempt and asks her if her decision is final and if she truly intends to leave. She says, "'I must. I believe it to be my duty, and am therefore willing to sacrifice my own comfort, and, what I assure you I value far more, your friendship"” (Cummins 146). A woman's duty — to God, to her friends, and to her own sense of righteousness - here becomes the basis for her assertion of self, of independence, and of free will. In explaining the situation some time later to some friends of hers, Gertrude says, "'I always considered it my duty to submit to him, until, at last, a higher duty compelled me to do otherwise"' (Cummins 157). This sentence can be read as the rallying cry of feminine deference which must not be maintained in the face of vice, selfishness, or tyranny or which is justified in being denied in favor of a perceived greater good; it expresses the foundational basis for any woman to assert her own self and her own will. ${ }^{9}$ As the novel unfolds further, Gertrude will have many other opportunities to push the boundaries of her expression of her own selfhood, but none are as meaningful and essential to Gertrude or her readers as this primary instance of it. Although she will eventually marry and

\footnotetext{
${ }^{9}$ Barnes suggests a complementary notion of this selfhood: "The Lamplighter traces the psychological mechanisms by which passionate individuals achieve their self-possession. What the novel's investigation reveals is, paradoxically, a relational model of selfhood that undergirds nineteenth-century notions of independence. Through the trope of conversion, The Lamplighter links self-determination to sympathetic mediation" (85). Whereas Barnes argues that this process must be mediated through the "eyes of an all-seeing Father," I maintain that, once internalized, the "relational model of selfhood" may be used to justify female agency even when the presence of "an all-seeing Father" is not overt; moreover, I would argue that the act of agency that initiated that mediation, namely choosing to seek salvation, is the overarching reason for the self-determination Barnes construes therein. Barnes refers to that Father's presence as a form of possession that happily results in the finding of one's self, but I contend that such a "possession," if it be that, is a step in the process that has only been initiated due to an act of agency (i.e. the desire to work for the salvation that only God can offer) on the part of the self. Barnes states that "Through her identification with the spiritual Father, Gertrude achieves a self-possession that is both consistent with and independent of public forms of control" (89). I heartily agree with the second half of that statement, but I suggest that it is through her own choice to seek out salvation that such a self possession is, ultimately, possible.
} 
thereby reinscribe many of the patriarchal values of the day, Gertrude marries her equal, Willie, as most female protagonists had not done heretofore; and although her own father comes to be a part of her life through a series of events and coincidences common to sentimental novels, his presence only serves to strengthen Gertrude's resolve to be her own decision maker. ${ }^{10}$

\section{Ruth Hall}

Published only nine months after The Lamplighter, Ruth Hall (December 1854) presents itself as the antithesis of a traditional woman's novel for that era; Fanny Fern herself calls it a "continuous story" that she will not "dignify...by the name of "A novel," in the Preface to her book. In fact, she says that she is "aware that it is entirely at variance with all set rules for novelwriting"” (Fern 3). At first glance, readers might have agreed. At times, its style is abrupt and choppy rather than flowery and verbose; it does not tell the story of a young girl who has been orphaned and must find her own way in the world; and it starts with the wedding of the main female character to her ideal mate rather than ending with the promise of happy marriage. But this story is still a coming-of-age tale for its protagonist, Ruth Hall. The salvation Ruth seeks may be almost entirely secular and material rather than religious, but she must earn it as surely as any of her literary sisters did, and she often does so with a reliance on religious discourse to emphasize the justness of her decisions. In so doing, Ruth embodies a vision of independent female selfhood and agency that may actually have been out of reach for many of her readers. Nevertheless, in modeling even the possibility of a life outside of the realm of material

\footnotetext{
${ }^{10}$ Barnes reads this return of the father as one that "offers a vision of domestic unity in which independence leads one back to the family" (91). I do not disagree. However, because Gertrude's defiance of her father's wishes (when he attempts to rescue her from a burning ship, but she gives him a veiled Isabel Clinton-Willie's employer's daughter and his presumed love interest - to rescue instead) is what eventually leads to the happy ending, I would endow that return with less significance than Barnes does (who uses it to perpetuate the trope of the father and the Father in the novel) and argue instead that it is Gertrude's own choices that bring about that joyous conclusion.
} 
dependency necessary for most women in that era, Ruth demonstrates for readers a kind of actual agency that had heretofore usually been beyond their conception. They may thereby vicariously begin to imagine a realm of true independence that could have colored their own conceptions of themselves for years to come. That such readers embraced this possibility is evidenced by the tremendous popularity of this novel that, despite some critics' denouncements of it, continued unabated well into the second half of the nineteenth century. ${ }^{11}$

Ruth Hall begins by challenging genre conventions from its very first paragraph; it opens not with the death of the mother but with the wedding of the protagonist as readers are immediately told that "On the morrow Ruth would be a bride." It also begins with a vision of nature's beauty that would have metaphorically suggested the presence of God's grace to most female readers of that time: "For hours she had sat there, leaning her cheek upon her hand, and gazing through the open space between rows of brick walls, upon the sparkling waters of the bay, glancing and quivering 'neath the moonbeams." As Ruth gazes out on this vision, she considers that this would be "the last time she would sit at that little window." Seemingly blessed by the light of moonbeams and sparkling water, Ruth will be getting married and, readers are told, "The morrow would find her in a home of her own" (Fern 13). This single opening paragraph thus encapsulates the usual tropes of domestic novels and fulfills their typically professed aimsnamely experiencing God's grace, establishing a literal or figurative space of one's own, and getting married-in only a few short sentences.

\footnotetext{
${ }^{11}$ Joyce W. Warren overviews some of the derogatory critiques of Ruth Hall in her Introduction to her edition of the text, many of which vilified Fern for her thinly-veiled, satiric portrayals of her own father and brother. Warren quotes one reviewer who wrote: "“As we wish no sister of ours, nor no female relative to show towards us, the ferocity she has displayed toward her nearest relatives we take occasion to censure this book that might initiate such a possibility" (xvii). That Fanny Fern, in the person of Ruth Hall, may have so publicly rejected her own family ties suggests the further evolution of the female self's ability to choose her own spiritual or social bonds. This public rejection seemed, ironically, to fuel sales of the book. Once the author's identity was revealed, and the reading public realized the connections between Ruth Hall's family and Fern's, sales skyrocketed, according to Warren.
} 
Ruth is uniquely positioned by this opening to contest those conventions, refigure them, and thereby reissue them in ways that would challenge the norms of sentimental novelistic discourse as most previous female protagonists could not have done. The role of religion in her life is one of the first conventions to be turned on its head by the plot of this novel. Although there are hints that exemplify God's presence in nature, and Ruth's professed love of nature signifies her own acceptance of God's grace, the first overt moment in which she expresses a direct relationship with God comes about after the birth of her first child, a daughter named (significantly) Daisy. ${ }^{12}$ As she plays outside, in the country, in her own yard, with her young child, the narrator directly illustrates Ruth's experience with God's grace for the first time: "Ruth had a strong, earnest nature; she could not look upon this wealth of sea, sky, leaf, bud, and blossom; she could not listen to the little birds, nor inhale the perfumed breath of morning, without a filling eye and brimming heart, to the bounteous Giver. Should she revel in all this loveliness, - should her heart be filled to its fullest capacity for earthly happiness, and no grateful incense go up from its altar to Heaven?" (Fern 29). Despite her ability to commune with nature and thus appreciate God's grace, up until this moment Ruth had never been portrayed as praying directly to God. Previous conventions of domestic literature would have imbued the role of the mother with a special significance in that she would be the one to bring her children, male and female, to God and encourage that relationship as a means of bringing about their ultimate spiritual salvation. Just after this moment in nature, though, Ruth's child is portrayed as the one to bring her mother to God: “...the maternal eye must never sleep at its post, lest the enemy rifle the casket of its gems. And so, by her child's cradle, Ruth first learned to pray. The weight her

\footnotetext{
${ }^{12}$ Susan K. Harris explains the communal system of codes and symbols with which readers of that era would have been familiar: "By associating Ruth with flowers and piety Fern creates a protagonist her readers will recognize as deeply feminine, a woman who feels as a woman should feel, and who therefore qualifies as a heroine the general culture can accept" $\left(19^{\text {th }}\right.$-Century American 113).
} 
slender shoulders could not bear, she rolled at the foot of the cross; and, with the baptism of holy tears, mother and child were consecrated" (Fern 29). This portrayal of the child as bringing her mother to God rather than the other way around is reinforced a few chapters later when Daisy, now a little girl, is playing with a caterpillar while outside with her mother: "“Oh, Daisy! Daisy!' said Ruth, stepping up behind her, 'what an ugly playfellow; put him down do darling; I cannot bear to see him on your arm.”" Daisy replies, “'Why_-God [emphasis's Fern's] made him,' said little Daisy, with sweet upturned eyes of wonder." Ruth's response shows that Daisy has once again succeeded in connecting her mother to God: “'True, darling,' said Ruth, in a hushed whisper, kissing the child's brow, with a strange feeling of awe. 'Keep him, Daisy, dear, if you like"” (Fern 37).

The next way in which Ruth Hall succeeds in reversing the normative expectations for women's writing comes about following a series of tragedies in the young mother's happy life. Rather than a tale wherein the female protagonist comes to know God first, and then comes to value her spiritual ties over her familial ones, and finally enacts her own salvation to such an extent that she is awarded with a happy ending (usually in marriage or in the promise of one), Ruth Hall begins with a happy marriage, and it depicts Ruth as already having cut ties with her blood relations. Her own mother had died many years before the beginning of this narrative, and Ruth had grown up mostly in boarding schools while having minimal contact with her father and brother, who are depicted as emotionally cold and condescendingly self-righteous. Her relationship of choice — rather than one of blood or obligation — with her kind, generous, and loving husband, Harry, is the primary one in her life until little Daisy comes along. Because Ruth and her daughter already know God, readers may not have expected that Daisy would fall ill and eventually die, but she does: "Slowly the night waned, and the stars paled. Up the gray 
east the golden sun slowly glided. One beam penetrated the little window, hovering like a halo over Daisy's sunny head. A quick, convulsive start, and with one wild cry (as the little throat filled to suffocation), the fair white arms were tossed aloft, then dropped powerless upon the bed of Death!” (Fern 45).

Clearly, Daisy has been taken to Heaven as the light of the "golden sun" and the "halo" would indicate; her death, though, is not intended to impel her mother towards salvation as the death of a loved one in other novels might have done. Instead, she seems to have died to save her the pain that future events in Ruth's life would bring. After her death, Ruth cries out, “'There can be no sorrow greater than this sorrow,' sobbed Ruth, as the heavy sod fell on Daisy's little breast." The opportunity to suggest that her death would result in some greater good, as it did when Mrs. Elton or Mrs. Montgomery died, is passed by here; instead, the narrator states that "In after years, when bitterer cups had been drained to the dregs, Ruth remembered these, her murmuring words. Ah! mourning mother! He who seeth the end from the beginning, even in this blow "remembered mercy"' (Fern 46). The implication here is that Ruth will experience many more tragedies in her life, but death has saved Daisy, mercifully, from knowing them.

Those tragedies come to pass, and they also illustrate the ways in which this story continues to challenge conventional plot lines. Eight years go by in only a few pages after the death of Daisy; in the intervening time, Harry and Ruth have two more daughters, Katy and Nettie. While Nettie is still a baby, Harry contracts a terrible fever and eventually dies, leaving Ruth in a state of spiritual destitution: "Oh, how could Ruth (God forgive her!) look upon those dumb lips [Harry's] and say, 'Thy will be done!'” (Fern 59). Despite her initial shock and grief that at first refuses to accept God's will, Ruth manages to turn back to God and rely on Him 
again in order to find the strength to mother her children after Harry's death. So, her children once more bring her to God rather than the other way around. When Ruth's father makes it clear that he will not help or support her and instead suggests that Ruth leave her children with Harry's parents, he argues that if Ruth should subsequently die after having refused this offer then the children will not have anyone to take care of them. Ruth replies that " Their Father in Heaven [emphasis Fern's] will...He says, "Leave thy fatherless children with me."," Ruth's father says that she is perverting scripture, but Ruth refuses to give up her girls even when her father tells her, "AAs you make your bed, so lie in it,"” before leaving (Fern 68). That night, Ruth kneels "by the side of those sleeping children, with upturned eyes, and clasped hands of entreaty, and lips from which no sound issued, though her heart was quivering with agony; and yet a pitying Eye looked down upon those orphaned sleepers, a pitying Ear bent low to list to the widow's voiceless prayer" (Fern 69). Ruth turns back to God and finds strength in Him because of her children. There is no indication here that she seeks Him to ensure her own spiritual salvation because she has already passed the point in her development wherein such salvation is typically sought, and, moreover, her soul is never depicted as being at risk in this novel; instead, she seeks the material salvation of finding a means of supporting herself and her children, and she leans on God in order to find the strength to do so. ${ }^{13}$

\footnotetext{
${ }^{13}$ In her Introduction, Warren contends that "Religion...is used differently in Fern's novel. In The Wide, Wide World and The Lamplighter, religion helps the heroine to gain a victory over self. But Ruth Hall finds in religion the encouragement she needs to continue her struggle for independence in defiance of her male relatives" (xxv). While I agree that religion is used differently here, I do not believe that it was used to "gain a victory over self" by Ellen Montgomery or Gerty; instead, those female protagonists used religion to justify their sense of self as rightly choosing to seek salvation. The novelistic discourse that depicted such justification as "control" over self served, in my opinion, to encourage those characters to take hold of themselves and make the choices that would lead to their own salvation. Warren reiterated a similar contention a couple of years later in her essay, "Domesticity and the Economics of Independence": “...unlike many of the women writers of her period who portrayed religion as an aid in women's 'practice of submission,' Fern saw religion as a spur to female achievement. In Susan Warner's The Wide, Wide World ... and Maria Cummins's The Lamplighter...religion helps the heroine to gain a victory over self and assists her in her struggle to put down her feelings of rebellion" (83). Nevertheless, I maintain that Ruth Hall had actually already moved beyond the place in her development wherein she might have used religion in a way similar to Ellen or Gerty; in depicting a female protagonist whose journey does not end in happy marriage but begins
} 
Ruth's reliance on God as a means of reinforcing her choice to seek out material salvation continues as her struggles do in the remainder of the narrative. Her will to survive and keep her children with her rather than handing them over to Harry's parents (who have been depicted unkind, selfish, and cold-hearted) forces her to accept a life of cheap boarding houses and menial odd jobs like sewing and doing laundry. At one point, when Ruth has just about lost hope, the narrator tells readers that "She [Ruth] knew now how it could be, when every door of hope seemed shut, by those who make long prayers and wrap themselves in morality as with a garment, and cry with closed purses and averted faces, 'Be ye warmed, and filled.' She knew now how, when the heart, craving sympathy, craving companionship, doubting both earth and heaven, may wreck its all in one despairing moment on that dark sea, if it lose sight of Bethlehem's guiding-star" (Fern 91). Ruth understands, then, why people turn away from God when they are so hopeless; at this moment, though, the kind hand of Providence intervenes—not to test Ruth as it has tested other heroines, but to reassure her that hope is still possible. Young Katy has run into a gentleman on the street who remembers her father with love and affection, and he has slipped a note and some money into Katy's bag. When she returns and gives it to her mother, the narrator shows the result: "'Hush,' whispered Katy to Nettie, 'mamma is praying"” (Fern 92). A prayer of thanksgiving is sent up to Heaven by Ruth as she expresses her gratitude for the small ray of hope sent by God's grace into her life in the spiritual form of a material kindness from one who cared for Harry. It thus fortifies her to continue her fight for material salvation.

Much like a sinner who must be brought to the lowest possible level of spiritual destitution before choosing to seek God, Ruth's utter material impoverishment must come about moving beyond the stereotypical happy ending to depict the consequences of that salvation in the life of the heroine after that moment of her marriage. Ruth must use her spiritual salvation to fuel her material one. 
before she will choose to seek the path of her own secular redemption. Shifting fortunes and the lack of consistent employment cause Ruth and her girls to seek out an even less expensive boarding house where they live mainly on bread and milk. One morning, while gazing out the window early because her own coughing has prevented her from sleeping soundly, Ruth sees a newspaper carrier pass by on the street and has a sudden revelation: "A thought! Why could not Ruth write for the papers? How very odd that it had never occurred to her before? Yes, write for the papers - why not? She remembered that while at boarding-school, an editor of a paper in the same town used often to come in and take down her compositions in short-hand as she read them aloud, and transfer them to the columns of his paper. She certainly ought [emphasis Fern's] to write better now than she did when an inexperienced girl" (Fern 115). Ruth makes the mistake, however, of thinking that her brother, Hyacinth, who is a "prosperous editor of the Irving Magazine," will help her rather than relying on herself and turning to God for strength as she has done before. She thinks that even if he cannot publish her writings himself, he can surely "point out to her some one of the many avenues so accessible to a man of extensive newspaperial and literary acquaintance" because, she thinks, "She would so gladly support herself, so cheerfully toil day and night, if need be, could she only win an independence" (Fern 115). Hyacinth refuses to help her, however, and does so in the most condescending and heartless way.

This rejection causes not bitter despondency but a declaration of strength from Ruth: “II can do it, I feel it, I will do it... it shall be done [emphases Fern's]"' she resolves. This moment is sanctified when her daughter Katy asks, “'What is it, mamma?” Ruth replies, “"what is it? only that when you are a woman you shall remember this day, my little pet;' and as she kissed Katy's upturned brow a bright spot burned on her cheek, and her eye glowed like a star" (Fern 116). This fierce light that shines out from her cheek and her eye harkens back to the light that 
Ellen Montgomery and Gertrude emitted when they had truly found God's grace. It signifies that this moment of determined independence has been consecrated by God and that now Ruth is on the path that will lead to her fulfillment.

Ruth's determination is blessed by God even more overtly a short time later; she has been making the rounds of the local papers and publishers, trying to get her work accepted, but has not had any success. Then, in a desperate bid to give her daughter a chance to eat well and live in the country, Ruth concedes to Harry's parents' wishes and allows Katy to go and live with them for what she hopes will only be a short time. One "Sabbath morning," Ruth, "sat in her little, close attic, leaning her head upon her hand, weary, languid and dejected." She considers that "Life seemed to her scarce worth the pains to keep its little flame flickering" as she feels that "A dull pain was in her temples, a heavy weight upon her heart." She seems dejected and nearly ready to give up: "earth looked so dark to her now, heaven so distant, God's ways so inscrutable" (Fern 122). At this moment, she hears a church bell ringing and decides to take Nettie and go to church. As she sits in the pew, listening to the Word of God, she has a revelation: "The bliss, the joy of heaven was pictured; life,-mysterious, crooked, unfathomable life, made clear to the eye of faith; sorrow, pain, suffering, ignominy even, made sweet for His sake, who suffered all for us." In offering up her own suffering to God as she knows it is but the merest shadow of the suffering of Christ, Ruth cries: 'Ruth weeps! weeps that her faith was for an instant o'erclouded; weeps that she shrank from breasting the foaming waves at the bidding of Him who said, 'It is I, be not afraid.' And she, who came there fluttering with a broken wing, went away singing, soaring" (Fern 123).

God's grace has given Ruth the inner strength she needs to persevere. The chapter ends, and the very next chapter in which she is featured begins with the words, "Ruth had found 
employment" (Fern 125). Ruth's ascent in the literary world thus begins with this one small step as an article of hers is accepted for publication in a minor newspaper. She writes more articles every day until late in the night while Nettie sleeps. One night, as she leans out the window for a breath of fresh air, she thinks, "How impressive the stillness!" and she "can almost hear her own heart beat." The quiet solitude where she hears her own strong heart beating, rather than listening to that of her husband or children, reinforces the vision of Ruth as solidly independent; then, "She looks upward, and the watchful stars seem to her like the eyes of gentle friends. No, God would not [emphasis Fern's] forsake her! A sweet peace steals into her troubled heart..." (Fern 126). Ruth's path to material salvation is made holy by her assurance that "God would not forsake her" and by the peace she feels when she realizes how righteous her ways have been. Ruth Hall's coming-of-age takes place, then, not with her spiritual maturation but with her material one. Her faith, while it certainly implies that her soul has been saved, in fact supplies her with the fortitude to bring about a secular salvation for herself and her daughters. After this, her fortunes continue to improve to the point where she surpasses even her own wildest dreams of success. She is able to move out of the slum, retrieve Katy, and take on several male publishers to ensure her own earnings are just. Although she concedes at one point that " "no happy woman ever writes"” and that "From Harry's grave sprang "Floy" [her nom de plume]," Ruth's remaining time in the novel is a steady ascent into a fulfilling life of her own making (Fern 175). While such an independence would not have possible for many women in her time, the modeling of it may have led women readers to envision and possibly even enact their own modes of independence and acts of free will in ways other than financial.

Ruth's story does not end with a reinscription of patriarchal values as The Lamplighter did when Gertrude married Willie (and was called "Gerty" by him during the scene in which 
they declared their mutual love, signifying her safe return to a domestic domain) and presumably gave up her teaching career. Instead, Ruth's narrative ends with a visit to her happy former home in the country and the grave of her husband. As she reflects on her "past joys - past sorrows_-past sufferings," Ruth looks at the space next to Harry's where her own head will eventually rest. At this moment, readers may imagine, perhaps along with her, what Ruth's life might be like had Harry not died. Out of his death came her life and her independence — perhaps not willingly, but it did nonetheless. When they drive away, “... a little bird, startled from out its leafy nest, trilled forth a song as sweet and clear as the lark's at heaven's own blessed gate." Ruth's friend advises her to "“Accept the omen...Life has much of harmony yet in store for you"" (Fern 211). And so ends Ruth Hall, with a sanctified message from a bird, a symbol of God's grace, that success is possible, that hope is possible, and that out of death can come new life.

\section{Conclusions}

My study begins and ends with novels named for their main characters, Charlotte Temple and Ruth Hall, which seems fitting considering how influential these two characters were in their own times and for so many years thereafter. How did the emblematic young women for whom these novels were named progress from being one who could only begin to express a tenuous realization of selfhood by choosing a path of sin that would inevitably lead to her own death in Charlotte Temple to one whose confidence in her own righteous agency was blessed by a symbol of God's grace after she had effected her own salvation in Ruth Hall? Several decades of cultural, political, and religious development in the intervening years between the publication of these two works saw American society mature from one which necessitated the subjugation of 
women in order to strengthen its national and political identity to one in which women had become moral leaders - in the home as they raised and educated worthy citizens, at the forefront of religious and benevolent societies, and in rallying the public in such causes as temperance, abolitionism, and suffrage. Those decades saw women transformed from sinners who threatened the ideals of a nation to saints who upheld the righteousness of God's will on earth in their families and in their communities. What that transformation cost them, and how they would deal with those losses, would shape the structures and subjects of novelistic discourse for many years to come. 


\section{Conclusions and Beyond}

The spark of sexual passion that signaled the genesis of the potential threat of female self interest in American women's novels in Charlotte Temple was safely put out by quenching its tiny flame in the blood of its heroine; such sacrifice of the sinning woman was employed to caution readers against any temptation to rebel and pursue those interests even as it vicariously allowed them to imagine the pleasures of doing so. The trope of the sinful, seduced woman was transfigured — by a complex process of social, political, religious, and literary development—into a saintly image of virtuous femininity as later novels internalized, reformed, and reissued those conventions by consecrating the sacrifice of the self as an act of selflessness on the part of the righteous woman who had experienced God's grace. In choosing to sacrifice willingly her own self interest to the needs of her children, her husband, and her community, those women could, paradoxically, recoup some small measure of agency by claiming the act of choosing as her own. Those model women could choose a path of spiritual fulfillment that, with the mantle of selfrighteousness thrown over their shoulders, allowed them to reconceive of the domestic sphere as the realm from which their influence could achieve its greatest power.

But their sainthood was predicated on their willingness to sacrifice their bodily desires in exchange for the type of free will offered by choosing spiritual fulfillment. In sketching out the ways in which novels reflected and influenced that transformation, a trajectory can be seen that would continue beyond these works for years to come as writers struggled to envision a world wherein such an exchange would no longer be necessary. Only in rejecting that power could works like The Hidden Hand, The Morgesons, or The Story of Avis begin to conceptualize of women as fully actuated selves, no longer simply sinners or saints. In briefly overviewing these three novels, I explicate just some of the many ways in which this trajectory was sustained by 
subsequent works of "woman's fiction." The Hidden Hand or, Capitola the Madcap (1859), by

E.D.E.N. Southworth, is a hilarious, melodramatic, satire that presents a mischievous heroine who quite literally takes on the role of a man by cross-dressing and playing the hero; in search of adventure, she rescues women and men, both literally and figuratively, while maintaining her strong moral center before marrying her childhood sweetheart at the end of the novel. The Morgesons (1862), by Elizabeth Stoddard, defies nearly all conventions of sentimental literature by exploring the extreme psychological consequences of the cult of domesticity for both men and women; it prefigures, decades before, the works of such authors as Charlotte Perkins Gilman, Kate Chopin, and Edith Wharton. Finally, The Story of Avis (1877), by Elizabeth Stuart Phelps, features a woman who wishes to pursue a career as an artist for her own sake rather than being brought to such a decision by the financial circumstances of her life as characters like Gerty or Ruth Hall were; she falls in love, though, and is persuaded to marry by her lover, and the ensuing struggle of both characters to succeed simultaneously in career and marriage is heartbreakingly depicted as futile.

Although The Hidden Hand makes the most of its melodramatic flair by weaving together a vast number of seemingly disparate storylines before tying them up in a series of fortunate coincidences that end in a happy marriage for its heroine, the main plot rarely otherwise conforms to the ideals of true womanhood that popular works of that era have been said to reflect. However, many of the secondary female characters do conform to those ideals, so, far from rejecting completely the stereotypical values of happy domesticity, The Hidden Hand manages to show their potential worth, while at the same time challenging the gender constraints that necessitated female submission and economic dependency. Capitola's story is a satiric adventure tale despite the fact that the bare particulars of her life follow the conventional 
sentimental plot line of a young, orphan girl who must make her own way in the world and who is, eventually, married to a virtuous young man. At the start of the novel, Capitola is an orphan living in a New York City slum — and cross-dressing as a boy to sell newspapers and get odd jobs: "'I could do just as well as they. And so because I was a girl, there seemed to be nothing but starvation or beggary before me...””; ““...but I took care of myself, sir!” (Southworth 44-5). Capitola actively demonstrates the limited financial options for women in her time by transforming herself into a man in order to find suitable work and not be reduced to begging. The transformation has the added benefit of protecting her from the threat of rape which pervades life on the streets; as Capitola tells it: "'Well, being always exposed, sleeping outdoors, I was often in danger from bad boys and bad men"' (45). In raising the threat of rape, The Hidden Hand directly addresses the issue of sex which is usually absent or barely implied in stereotypical domestic novels; its reintroduction here makes way for the possibility of a more fully developed female protagonist who need not suppress her material body in order to seek spiritual salvation. When Cap is forced to return to Virginia (where she had been born and is, unbeknownst to her, an heiress), she deliberately seeks out adventures (because "the very absence of the necessity of thinking and caring for herself, left a dull void in her heart and brain" (Southworth 174)) that include fighting a duel and rescuing a woman from her would-be rapist. As Old Hurricane (the gentleman who has taken her back to Virginia) tells it: “'Cap isn't sentimental [emphasis Southworth's]!"” and "“Cap evidently thinks that the restriction of her liberty is too heavy a price to pay for protection and support!"” Later, Cap saves herself from her own potential rapist, the pirate Black Donald, by using her wits to outsmart him because she knows she cannot match his physical strength. In her depiction of Black Donald, Southworth draws him as six feet, eight inches tall, bearded, and menacing, as if to satirize the huge, 
threatening stature of men as compared to women — but her description also paints Black Donald as the very image of rampantly attractive male sexuality. This may contribute to Capitola's decision to give him a chance to redeem himself and show that he can be reformed; she also admires his forceful personality and believes that he has the potential to be good. Even when he has been jailed for his attempts on Capitola and his other crimes, she uses the reward money she earned for capturing him to help him escape — on the eve of her own wedding day — and exhorts him to "'try to lead a good life, and may God redeem you"” (Southworth 480). The physical attraction between Capitola and Black Donald has been nearly irresistible to her and she almost gives in to his advances; that she ultimately rejects him as a lover but still helps to set him free speaks to the fact that Capitola is more capable of understanding her own physical and emotional needs than most heroines in stereotypical domestic tales. In freeing him but refusing to run away with him, despite their mutual attraction, Capitol demonstrates her capacity to make conscious choices about her own well-being. Eventually, Capitola's mother is found to be alive, having been kept in an insane asylum by the man who wished to control Cap's inheritance, her dead father's brother. Capitola marries her childhood sweetheart, who is also Old Hurricane's nephew, the virtuous and handsome Herbert Greyson, who had taught her to read and never drink alcohol when they were children. In choosing marriage with a morally upstanding and yet still attractive man, Capitola shows herself capable of assessing her own needs, both spiritual and physical. By the novel's end, she seems mostly reformed of her adventure-seeking ways, but the narrator cautions, in the closing lines of the book, that she "know[s] for a positive fact, that our Cap sometimes gives her 'dear, darling, sweet Herbert,' the benefit of the sharp edge of her tongue, which of course he deserves" (Southworth 485). The popularity of a novel that flouted so many of the conventions deemed appropriate for "woman's fiction" suggests that readers of 
that time may have been ready to imagine challenging those norms rather than blindly conceding to them. Although the novel initially depicts the submissive female characters who fail to question the men in their lives as coming to ruin and living in poverty or the madhouse, Cap rescues them all and, in the process, also manages to reform the men who mistreated them. In so doing, The Hidden Hand suggests that domesticity's potential for abuses may be overcome by strong women who are willing to help educate and reform wayward men. The narrator reports at the close of the tale that "they all enjoy a fair amount of human felicity" (Southworth 485). The story ends with the sense that it is not Capitola who has come of age, then, but every other person in her life who has now been taught by her how to value and respect each other, regardless of gender.

Elizabeth Stoddard's The Morgesons (1862), while still a bildungsroman, refuses almost entirely to participate in sentimental discourse; instead it demonstrates the consequences of female submission while also portraying the utter futility of any attempts at rebellion. Unlike sunnier novels that offer women readers some hope of redemption or independence, or that at least paint the joys of marriage as worthy of their price, The Morgesons is unique in its dystopian view of the domestic realm as isolated, dark, and full of unseen dangers. ${ }^{1}$ The constraints placed on women are shown to be almost equally damning to men; by tying their fortunes to each other, marriage does little to alleviate the psychological burdens with which each sex has been harnessed by the culture of the day. No positive outcome is offered for any of these characters, and they all come away psychologically and physically scarred (or dead) as a result of their futile

\footnotetext{
${ }^{1}$ As Susan K. Harris asserts in her chapter, "Projecting the 'I'/Conoclast: First-Person Narration in The Morgesons," "The Morgesons is quite possibly the most radical women's novel to appear in the mid-nineteenth century, and yet it expresses its heresies without ever moving its protagonist, Cassandra Morgeson, out of the domestic sphere" (152). Therefore, Harris argues, "What radical possibilities The Morgesons offers, then, occur in the psychological rather than the professional aspects of Cassandra's development" (19 $9^{\text {th }}$-Century American 152).
} 
attempts at domestic happiness. The novel opens with Cassandra Morgeson's aunt's declaration, in the very first line, that "That child...is possessed"" (Stoddard 5). As the novel proceeds to its close, however, her aunt changes her assessment of Cassy: “'I wish I could say,' she said, 'what I used to say to you,- - that you were "possessed"," (Stoddard 237). And, a few pages later, Cassy herself reflects, "I regained an absolute self-possession” (Stoddard 248). Cassy's coming of age, then, is characterized by her journey from "possession" to "self-possession," but she finds that, in the end, self-possession is nearly as unsatisfying as possession had been. The Morgesons depicts the adolescent girls at the center of the story, Cassy and her younger sister Veronica (Verry), as needing to harness those untamed aspects of female nature which typically begin to emerge in adolescence — sexuality and individuality — by means of the domestic vehicles with which women became complicit in their own subjugation. In acknowledging the sexual and psychological development of its main character, The Morgesons depicts a female self whose needs go beyond the spiritual or material. Cassy instead seeks "self-possession," and chooses to leave the family home to live with her cousins, but the consequences are disastrous: her unchecked sexuality looms out of control and leads to a fatal carriage accident that leaves her on the verge of death and kills her married, would-be lover. Verry, on the other hand, takes her self control to such an extreme that she only subsists on toast with milk and thereby renders her own body perpetually gaunt and child-like. Although neither girl need marry for financial reasons, they eventually choose to marry Desmond and Ben Somers, brothers who have been rendered financially powerless by their mother's family's trust (thus mirroring the girls' own powerlessness in the domestic sphere). The men of the Somers family suffer from chronic alcoholism, a condition begotten upon them by an impotent, gout-ridden father who is ruled by his wife and her family's money and who fails to model a socially appropriate masculine 
presence in their lives. Neither Desmond nor Ben can inherit from their mother's family's trust until the youngest male heir reaches the age of twenty-one. When Ben, the younger son, is on the very cusp of this achievement, his mother, against all odds, becomes pregnant and bears a son. Ben and Desmond, the respective male mirror images of Veronica and Cassandra, deal with this turn of events in ways that parallel the coping mechanisms of the sisters. Ben avoids the world by staying home and regulating his physical body by self-medicating with alcohol (which eventually leads to his death), while Desmond leaves his home to go out into the world (in this case, Spain) where he can best learn how to overcome his dependency and maternal possession. Although Desmond returns and he and Cassy do marry, their relationship is stunted by each of their separate efforts at self-possession. That self-possession comes at a high price; they have no children, and Cassy's last description of the sea, which had previously stood for her ebbing and flowing sexual passion, seems to suggest that she has relinquished all hope of healthy sexual desire: "These last words I write in the summer time at our house in Surrey, for Desmond likes to be here at this season, and I write in my old chamber. Before its windows rolls the blue summer sea. Its beauty wears a relentless aspect to me now; its eternal monotone expresses no pity, no compassion" (252). The ending tone of the novel is far from triumphant or hopeful. Instead, it seems to realize the steep price that all of its characters have paid to reach this final point. In gaining some chimera of independence without leaving the domestic sphere, Cassy has to relinquish the passionate ideals of her youth as represented by the sea; maturation, despite an apparent love marriage, leaves Cassy permanently disconnected from this prior passionate aspect of her own self. Nevertheless, The Morgesons offers readers a female protagonist who directly acknowledges her own desires, and in particular her bodily passions, and who seeks to understand them at whatever cost; in this sense, it was truly revolutionary. 
The Story of Avis, a tragic kunstlerroman, continues this line of futility, but it does so by voicing directly the frustration Avis foresees for herself should she choose to give up the artistic life for which she believes herself destined by marrying her lover, Philip Ostrander. Her artistic goals represent her ability to find self fulfillment whereas her love and passion for Philip represent her sexual fulfillment; these two yearnings are connected in the novel by references to God, God's will, and a significant scene in a church wherein Avis fleetingly experiences a momentary glimpse of achieving both at the same time. Although The Story of Avis ultimately sees an affirmative joining of these two desires - psychological and physical—as not yet attainable for women, it nevertheless offers readers hope for it to be feasible someday. The religious discourse and imagery serve to consecrate that potential in the figure of Avis and bring to fruition the trajectory begun by Charlotte Temple nearly one hundred years earlier. Unlike her novelistic forebears, the salvation that Avis seeks is a fully developed one that would not require her own destruction, nor would it demand her complicity in her own subjugation as the price for it, nor would it necessitate that she choose between spiritual or material self actualization. For a female main character to acknowledge that she has dreams and goals for herself that have nothing to do with domestic fulfillment was remarkable; that she did so while still recognizing her own yearning for a lover to understand and support those dreams, rather than rescue her from them, was, perhaps, an unattainable fantasy in that time. ${ }^{2}$ For more than half the novel, The Story of Avis entertains the hopeful possibility that men and women can enter into a truly equal union of souls in marriage without either one of them having to sacrifice their own identities in the process. Avis's mother had given up a life in the theatre to marry her father, a professor at the local university; she died of an indistinct nervous condition, which the novel clearly suggests

\footnotetext{
${ }^{2}$ The character of Jo in Louisa May Alcott's Little Women struggled with these same issue a few years earlier than Avis did (1868/1869). Alcott's take is more optimistic than Phelps's, although Jo is a character in an ensemble cast rather than the lead, as Avis was; her career after marriage is also not the centerpiece of the story as it is for Avis.
} 
was the result of her blighted talent, when Avis was not yet ten. At the moment of her mother's death, Avis offers her a drawing she has made of a bird, signifying her latent artistic talent. After her death, her father's sister comes to live with them and attempts to domesticate the untutored child by forcing her to do needlework and make puddings, but to no avail. When Avis is sixteen, she has an epiphany after reading Elizabeth Barrett Browning's epic poem Aurora Leigh one sunny morning while perched in an apple tree: "It had come to her now-it had all come to her very plainly_ —why she was alive; what God meant by making her...” (Phelps 32). After having this consecrated vision of her own potential, she walks straight from the orchard to her father's study and says, "“Papa, I should like to be an artist, if you please."” "'Nonsense!?" is his unsympathetic reply to this declaration (Phelps 33). But he loves her dearly and consents to educate her in Florence as long as she agrees to " fret no more about "being" this or that"; he advises her that her "“business at present is to "be" a studious and womanly girl"” (Phelps 34). One year abroad turns into six, during which time her father continues to support her, and she is finally told by her teachers that she is ready to return home and make her mark on the artistic world. In the wake of realizing her life's goal, which she can scarcely believe, Avis "wandered about Paris like a spirit in a vision"; she stumbles into a church and therein chances to meet the eye of a man: "Avis, in that flash, said, "There is a remarkable face!" The narrator explains that the artist's eye is always taken with such visions, but "If the eye of that amber god [the man] across the Madeleine [the church] had caught an artist, it had held a woman. Avis became aware of this with a scorching, maidenly self-scorn. She dropped her veil, and hurried from the church" (Phelps 38-9). The moment of her greatest artistic triumph is also, then, the moment in which she becomes aware of herself as a woman; it is as if the fulfillment of one desire has opened the door to another, of which she had been unaware until that very moment. That this 
moment takes place in a church confers upon her sexual awakening an aura of holy

sanctification. When Avis returns home, to paint and attempt to fulfill her potential as an artist, she chances to meet a new tutor who works at the college-it is the same young man. After weeks of torturing herself by trying to resist her obvious passion for him (and his for her), Avis tells Philip, “'The plain word is, that I do not, and I must not, think of love, because the plain truth is, that I cannot accept the consequences of love as other women do." Philip protests, and she, fearing he believes her cold, cries out, "II am human, I am woman! I have had my dreams of love like other women!'” Philip claims he will not shackle her with domestic duties and tells her, "“You should be happy. You should paint. I should be proud to have you paint. I used to think I should be wretched with a gifted wife (all young men do); but you have taught me better. It would be the purpose - do not think it the ravings of a lover if I say it would be the passionof my life to help you realize your dreams of success"” (Phelps 68-9). Avis cannot believe this and maintains her position, telling him that God has given her talent to her, and that "“For your soul's sake and mine, you are the man I will [emphasis Phelps's] not love." Her "will" is broken when Philip enlists, following her rejection, and is subsequently wounded in the Battle of Bull Run. As she nurses him back to health, she weakens, but still maintains, "'I had rather not be happy than to be happy at such a cost as marriage demands of women"' (Phelps 106). Philip argues that it is the will of God that man and woman marry; she responds, "But I do not see it to be his will for me...He has set two natures in me, warring against each other. He has made me a law unto myself- $-\mathrm{He}$ [emphasis Phelps's] made me so."” Philip, blinded by love, replies, “"I do not want your work, or your individuality. I refuse to accept any such sacrifice from the woman I love. You are right. A man ought to be above it. Let me be that man"' (Phelps 107). He is absolutely sincere, and, although she worries that she will make him miserable and he will come 
to resent her, Avis eventually agrees to marry him. Had this scene come about at the end of the novel, The Story of Avis would have offered a utopian vision of a world where men and women could be true equals, even in marriage; but it occurs in the middle of the story and is the turning point of it. The remainder of the tale is devoted to depicting, in heartbreaking specificity, the ruin of their blissful, idealistic vision by the common domestic demands of everyday life, like the making of coffee or the coldness of his dinner: "The point at which love ceases to be per se an occupation, is seldom more distinctly defined than the line which divides the fire of sunset from the calm of the upper sky," the narrator explains (Phelps 148). The "occupation" of everyday life, which eventually includes children, continually delays Avis from realizing her artistic vision; the promised studio is never built, and "life had become a succession of expectancies" that puts off her work by small steps rather than all at once (Phelps 149). At one point, following a fight, Philip says, ““Avis, I was a brute!” She responds, “'No...you were only a man”” (Phelps 155). Although Phelps's depiction of marriage disallows the possibility of mutually-shared individuality wherein women need not surrender their selves, her portrayal of Avis as a strong woman who is able to vocalize her competing passions does at least acknowledge the potential for fully integrated personhood which female characters had for so long been denied. Near the close of the novel, the narrator explains, "We have been told that it takes three generations to make a gentleman: we may believe that it will take as much, or more, to make A WOMAN [emphasis Phelps's]" (Phelps 246). The story ends with Avis's hope that her daughter might go forth in the world and be such a woman.

Perhaps now, in our own time, we as readers of American women's novels can look back and visualize the ancestral line of generations of female protagonists just as Avis pictured her own family history, from her mother's artistic abdication to her own struggle for expression to 
her daughter's potential for fulfillment. As such, Charlotte Temple, the naïve daughter, would mother an Eliza Wharton, who in turn would help to produce an Emily Hammond, then a Jane Elton, an Ellen Montgomery, a Gertrude Flint, a Ruth Hall, and so on... literary mothers begetting literary daughters in an ever-increasing trajectory of potential. This vision is idealistic and profoundly hopeful, and it suggests a relationship between these works that women in the nineteenth century never would have considered. Every critical reading reflects the time in which it is written; critics of these novels in the 1970s and 1980s often saw them as feminist narratives of subversion, while those in the 1990s and early 2000s saw them more often as speaking to issues of national identity from a woman's point of view. In viewing the hopeful potential for these texts to express an escalating line of female agency, we are seeing the joyful promise for our world today "to make A WOMAN." 


\section{Works Cited}

Abzug, Robert H. "Benjamin Rush and Revolutionary Christian Reform." The Forgotten Founders on Religion and Public Life. Ed. Daniel L. Dreisbach, Mark David Hall, and Jeffry H. Morrison. Notre Dame: U of Notre Dame P, 2009.

Altman, Janet Gurkin. Epistolarity: Approaches to a Form. Columbus: Ohio State UP, 1982.

Austen, Jane. Pride and Prejudice. 1813. Ed. Carol Howard. New York: Barnes and Noble Classics, 2003. Print.

Barnes, Elizabeth. States of Sympathy: Seduction and Democracy in the American Novel. New York: Columbia UP, 1997. Print.

Baym, Nina. Introduction. The Lamplighter. By Maria Susanna Cummins. New Brunswick, NJ: Rutgers UP, 1995. ix-xxxi. Print.

---. Woman's Fiction: A Guide to Novels by and about Women in America 1820-1870. $2^{\text {nd }}$ ed. Urbana: U of Illinois P, 1993. Print.

Bolton, Charles Knowles. The Elizabeth Whitman Mystery. Peabody, Mass.: Peabody Historical Society, 1912. The Library of Congress Internet Archive. PDF file.

Braude, Ann. Sisters and Saints: Women and American Religion. Oxford: Oxford UP, 2008. Print.

Butler, Jon. Awash in a Sea of Faith: Christianizing the American People. Cambridge: Harvard UP, 1990. Print.

Cott, Nancy F. The Bonds of Womanhood: “Woman's Sphere” in New England, 1780-1835. New Haven: Yale UP, 1977. Print.

Cummins, Maria Susanna. The Lamplighter. 1854. Ed. Nina Baym. New Brunswick, NJ: Rutgers UP, 1995. Print. American Women Writers. 
Curiosos. "Miscellany. For the Centinel." Massachusetts Centinel, 20 Sept. 1788. OIEAHC.

Omohundro Institute of Early American History and Culture, 2012. Web. 15 Feb. 2012.

Davidson, Cathy N. Forward. Kelroy. By Rebecca Rush. Oxford: Oxford UP, 1992. v-vii. Print.

---. Introduction. The Coquette. By Hannah W. Foster. Oxford: Oxford UP, 1986. vii-xx. Print.

--- "The Life and Times of Charlotte Temple: The Biography of a Book." Reading in America:

Literature \& Social History. Ed. Cathy N. Davidson. Baltimore: The Johns Hopkins UP, 1989. 157-179. Print.

---. Revolution and the Word: The Rise of the Novel in America. Expanded ed. Oxford: Oxford UP, 2004. Print.

Edwards, Jonathan. "Sinners in the Hands of an Angry God." The Norton Anthology of American Literature. $7^{\text {th }}$ ed. Ed. Nina Baym. New York: W.W. Norton and Co., 2007. 425-36. Print.

Fern, Fanny. Ruth Hall. 1854. Ed. Joyce W. Warren. New Brunswick, NJ: Rutgers UP, 1991. Print. American Women Writers.

Fliegelman, Jay. Prodigals and Pilgrims: The American Revolution Against Patriarchal Authority, 1750-1800. Cambridge: Cambridge UP, 1982. Print.

Foucault, Michel. The Use of Pleasure: Volume 2 of The History of Sexuality. Trans. Robert Hurley. New York: Vintage, 1990. Print.

Foster, Hannah Webster. The Coquette. 1797. Ed. Cathy N. Davidson. Oxford: Oxford UP, 1986. Print. Early American Women Writers.

Ginzberg, Lori D. Women and the Work of Benevolence: Morality, Politics, and Class in the $19^{\text {th }}$ Century United States. New Haven: Yale UP, 1990.

Grasso, Christopher. A Speaking Aristocracy: Transforming Public Discourse in Eighteenth- 
Century Connecticut. Chapel Hill: U of North Carolina P, 1999. Print.

Harris, Susan K. $19^{\text {th }}$-Century American Women's Novels: Interpretive Strategies. Cambridge: Cambridge UP, 1990. Print.

---. Introduction. A New-England Tale. By Catharine Maria Sedgwick. New York: Penguin Books, 2003. vii-xx. Print.

Herndl, Diane Price. Invalid Women: Figuring Feminine Illness in American Fiction and Culture, 1840-1940. Chapel Hill: U of North Carolina P, 1993. Print.

Holifield, E. Brooks. Theology in America: Christian Thought from the Age of the Puritans to the Civil War. New Haven: Yale UP, 2003. Print.

Howe, Daniel Walker. What Hath God Wrought: The Transformation of America, 1815-1848. Oxford: Oxford UP, 2007. Print.

Kerber, Linda. "The Republican Mother: Women and the Enlightenment-An American Perspective.” American Quarterly 28.2 (Summer 1976): 187-205. J-Stor. Web. 3 May 2012.

Nelson, Dana. Introduction. Kelroy. By Rebecca Rush. Oxford: Oxford UP, 1992. xi-xxiv. Print. Noble, Marianne. "The American Gothic.” A Companion to American Fiction 1780-1865. Ed. Shirley Samuels. Malden, MA: Blackwell Publishing, 2004. 168-78. Print.

Noll, Mark A. America's God: From Jonathan Edwards to Abraham Lincoln. Oxford: Oxford UP, 2002. Print.

Phelps, Elizabeth Stuart. The Story of Avis. 1877. Ed. Carol Farley Kessler. New Brunswick, NJ: Rutgers UP, 1985. Print.

Piepmeier, Alison. Out in Public: Configurations of Women's Bodies in Nineteenth-Century America. Chapel Hill: U of North Carolina P, 2004. 
Rowson, Susanna. Charlotte Temple. 1794. Ed. Ann Douglas. New York: Penguin, 1991. Print. ---. Lucy Temple. 1828. Ed. Ann Douglas. New York: Penguin, 1991. Print.

Rush, Jacob. Charges, and Extracts of Charges, on Moral and Religious Subjects, Delivered at Sundry Times by the Honorable Jacob Rush. Philadelphia, 1804. Hathi Trust Digital Library. Web. 12 June 2012.

Rush, Rebecca. Kelroy. 1812. Ed. Dana D. Nelson. Oxford: Oxford UP, 1992. Print. Early American Women Writers.

Rust, Marion. Prodigal Daughters: Susanna Rowson's Early American Women. Chapel Hill: U of North Carolina P, 2008. Print.

“Salem, July 29.” Salem Mercury, 29 July 1788. OIEAHC. Omohundro Institute of Early American History and Culture, 2012. Web. 15 Feb. 2012.

Schweitzer, Ivy. Perfecting Friendship: Politics and Affiliation in Early American Literature. Chapel Hill: U of North Carolina P, 2006. Print.

Sedgwick, Catharine Maria. A New-England Tale. 1822. Ed. Susan. K. Harris. New York: Penguin Books, 2003. Print.

---. The Power of Her Sympathy: The Autobiography and Journal of Catharine Marie Sedgwick. Ed. Mary Kelley. Boston: The Massachusetts Historical Society, 1993. Print.

Smith-Rosenberg, Carroll. Disorderly Conduct: Visions of Gender in Victorian America. Oxford: Oxford UP, 1985. Print.

Southworth, E.D.E.N. The Hidden Hand or, Capitola the Madcap. 1859. Ed. Joanne Dobson. New Brunswick, NJ: Rutgers UP, 1988. Print. American Women Writers.

Stern, Julia A. The Plight of Feeling: Sympathy and Dissent in the Early American Novel. Chicago: U of Chicago P, 1997. Print. 
Stoddard, Elizabeth. The Morgesons. 1862. Eds. Lawrence Buell and Sandra A. Zagarell. Philadelphia: U of Pennsylvania P, 1984. Print.

Tompkins, Jane. Sensational Designs: The Cultural Work of American Fiction 1790-1860. Oxford: Oxford UP, 1985. Print.

---. “Susanna Rowson, Father of the American Novel.” The (Other) American Traditions: Nineteenth-Century Women Writers. Ed. Joyce W. Warren. New Brunswick: Rutgers UP, 1993. Print.

Warner, Susan. The Wide, Wide World. 1850. Ed. Jane Tompkins. New York: The Feminist Press, 1987. Print.

Warren, Joyce W. "Domesticity and the Economics of Independence: Resistance and Revolution in the Work of Fanny Fern." The (Other) American Traditions: Nineteenth-Century Women Writers. Ed. Joyce W. Warren. New Brunswick, NJ: Rutgers UP, 1993. 73-91. Print.

---. Introduction. Ruth Hall. By Fanny Fern. New Brunswick, NJ: Rutgers UP, 1991. ix-xxxix. Print.

Waterman, Bryan. "Elizabeth Whitman's Disappearance and Her 'Disappointment." The William and Mary Quarterly 66.2 (Apr. 2009): 325-64. J-Stor. Web. 29 Jan. 2012.

Welter, Barbara. Dimity Convictions: The American Woman in the Nineteenth Century. Athens: Ohio UP, 1976. Print.

Westerkamp, Marilyn J. Women and Religion in Early America 1600-1850: The Puritan and Evangelical Traditions. London: Routledge, 1999. Print.

Weyler, Karen. “'A Tale of Our Own Times’: Early American Women’s Novels, Reprints, and the Seduction of the Familiar." Early American Literature 48.1 (2013): 231-42. Print. 